\title{
Law and Ecology
}

Law and Ecology: New Environmental Foundations contains a series of theoretical and applied perspectives on the connection between law and ecology, which together offer a radical and socially responsive foundation for environmental law. While its legal corpus grows daily, environmental law has not enjoyed the kind of jurisprudential underpinning generally found in other branches of law. This book forges a new ecological jurisprudential foundation for environmental law - where 'ecological' is understood both in the narrow sense of an ecosystemic perspective on law and in the broad sense of critical self-reflection of the mechanisms of environmental law as they operate in a context where boundaries between the human and the non-human are collapsing, and where the traditional distinction between ecocentrism and anthropocentrism is recast. Addressing current debates - including the intellectual property of bioresources; the protection of biodiversity in view of tribal land demands; the ethics of genetically modified organisms; the redefinition of the 'human' through feminist and technological research; the spatial/geographical boundaries of environmental jurisdiction; and the postcolonial geographies of pollution - Law and Ecology redefines the way environmental law is perceived, theorised and applied. It also constitutes a radical challenge to the traditionally human-centred frameworks and concerns of legal theory.

Andreas Philippopoulos-Mihalopoulos is Professor of Law \& Theory at the University of Westminster. 


\section{Law, Justice and Ecology}

Series editor: Anna Grear

Bristol Law School, UWE

In an age of climate change, scarcity of resources, and the deployment of new technologies that put into question the very idea of the 'natural', this book series offers a cross-disciplinary, novel engagement with the connections between law and ecology. The fundamental challenge taken up by the series concerns the pressing need to interrogate and to re-imagine prevailing conceptions of legal responsibility, legal community and legal subjectivity, by embracing the wider recognition that human existence is materially embedded in living systems and shared with multiple networks of non-humans.

Encouraging cross-disciplinary engagement and reflection upon relevant empirical, policy and theoretical issues, the series pursues a thoroughgoing, radical and timely exploration of the multiple relationships between law, justice and ecology. 


\section{Law and Ecology}

New Environmental Foundations

Edited by

Andreas Philippopoulos-Mihalopoulos

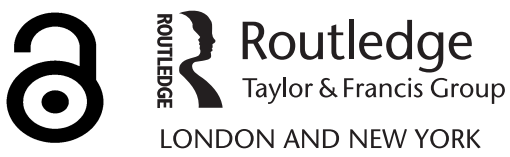


First published 2011

by Routledge

2 Park Square, Milton Park, Abingdon, Oxon. OX 14 4RN

Simultaneously published in the USA and Canada

by Routledge

711 Third Avenue, New York, NY 10017

\section{A GlassHouse book}

Routledge is on imprint of the Taylor \& Francis Group, an informa business

First issued in paperback 2012

(C) 20II editorial matter and selection: Andreas Philippopoulos-Mihalopoulos; individual chapters: the contributors.

The right of Andreas Philippopoulos-Mihalopoulos to be identified as editor of this work has been asserted by him in accordance with sections 77 and 78 of the Copyright, Designs and Patents Act 1988.

Typeset in Times by Taylor \& Francis Books Printed and bound in Great Britain by CPI Antony Rowe, Chippenham, Wiltshire

The Open Access version of this book, available at www.taylorfrancis.com, has been made available under a Creative Commons Attribution-Non Commercial-No Derivatives 4.0 license.

British Library Cataloguing in Publication Data

A catalogue record for this book is available from the British Library

Library of Congress Cataloguing in Publication Data

Law and ecology: new environmental foundations/edited by Andreas

Philippopoulos-Mihalopoulos.

p. $\mathrm{cm}$.

Includes bibliographical references and index.

ISBN 978-0-4 I5-587I 3-6 (alk. paper)

I. Environmental law. I. Philippopoulos-Mihalopoulos, Andreas.

K3585.L385 201I

344.04 ? 6 - dc22

2010037052

ISBN13: 978-0-415-58713-6 (hbk)

ISBN13: 978-0-415-62878-5 (pbk)

ISBN13: 978-0-203-82969-1 (ebk) 


\section{Contents}

List of contributors

vii

Series editor's preface

1 Looking for the space between law and ecology

ANDREAS PHILIPPOPOULOS-MIHALOPOULOS

2 Towards a Critical Environmental Law

ANDREAS PHILIPPOPOULOS-MIHALOPOULOS

3 Foucauldian-inspired discourse analysis: a contribution to critical environmental law scholarship?

BETTINA LANGE

4 The ecological narrative of risk and the emergence of toxic tort litigation

JO GOODIE

5 The precautionary principle: practical reason, regulatory decision-making and judicial review in the context of functional differentiation

JOHN PATERSON

6 Biotechnology as environmental regulation

ALAIN POTTAGE

7 Perspectives on environmental law and the law relating to sustainability: a continuing role for ecofeminism?

KAREN MORROW

8 Animals and the future salvation of the world 
9 Seeking spatial and environmental justice for people and places within the European Union ANTONIA LAYARD AND JANE HOLDER

10 Heterotopias of the environment: law's forgotten spaces ANDREAS KOTSAKIS

11 Majesty and monstrosity: Deleuze and the defence of Nature MARK HALSEY

Index 


\section{List of contributors}

Jo Goodie is a Senior Lecturer in Law at Murdoch University, Perth WA. Reflecting on her work as a toxic-tort lawyer, her recent publications have focused on the interface of legal and non-legal understandings of environmental risk. She is working on a contextualist historiography of the conception and constant reconception of the environment in the legal domain.

Piyel Haldar is Senior Lecturer in Law at Birkbeck College, London. He has published in a wide range of fields in legal history and is working on the staging of the distinction between animals and humanity in law. His interest in animal literature began shortly after the birth of his daughter Lila.

Mark Halsey teaches criminal justice in the Law School, Flinders University, Adelaide SA. He is the author of Deleuze and Environmental Damage and has a long-standing interest in the sociolegal construction of environmental harm, particularly with regard to the envisioning, regulation and exploitation of forests. His work has appeared in the edited collections Deleuze/Guattari and Ecology and Deleuzian Encounters as well as in various journals. $\mathrm{He}$ is researching the dark (unremarked) figure of carbon emissions in the context of climate change policy.

Jane Holder is Professor of Law at University College London. Her research interests are land use and development decision-making regulation, EU environmental law, common ownership, 'green' legal theory, environmental justice and issues of environmental identity, environmental citizenship and sustainability in the university sector. In association with Capacity Global she has established an Environmental and Community Clinic at UCL, staffed by students and academics working on environmental law and related policy areas.

Andreas Kotsakis is a $\mathrm{PhD}$ candidate in the Law Department of the London School of Economics. He has taught environmental law at the University 
of Westminster and legal method at the School of Oriental and African Studies. His research interests lie in the areas of critical legal theory, international environmental law and policy, Foucauldian analysis, geography, environmental history and philosophy.

Bettina Lange is Lecturer in Law and Regulation at the Centre for Sociolegal Studies, Oxford University. Bettina is working on a research project on the invocation of emotion discourses in EU regulation of transgenic agriculture, and with Dr Nafsika Alexiadou, Keele, on the deployment of soft modes of governance for achieving convergence of education policies in the EU. Her book Implementing EU Pollution Control: Law and Integration (2008) explores from a discourse analysis perspective the contribution of environmental 'law in action' to EU integration.

Dr Antonia Layard, Cardiff, researches law and geography at the local, national and EU level, particularly the 'law of place'. She is working with Professor Jane Holder on 'Creating European Territory: Law, Environmental Protection and the EU's Land Project'.

Karen Morrow is Professor of Environmental Law at Swansea University and Co-director of the Centre for Environmental and Energy Law and Policy (CEELP). She has published widely on environmental law and policy and her research interests focus on theoretical and practical aspects of public participation in environmental decision making. She is deputy convenor of the Environment Panel of the Society of Legal Scholars and a visiting member of Faculty on the LLM in Environmental and Energy Law at the University of Leuven. She co-edits the Journal of Human Rights and Environment and the IUCN Academy e-journal.

John Paterson is Reader in Law and Co-director of the Centre for Energy Law at the University of Aberdeen. His research has covered systems theory, the regulation of risk, governance in the EU, corporate governance and energy law. He has been involved in a number of international projects both in research and teaching and has acted as a consultant for the OECD's Nuclear Energy Agency. He is editor (together with Professor Julian Webb) of the Law, Science and Society series published by Routledge Cavendish.

Andreas Philippopoulos-Mihalopoulos is Professor of Law \& Theory, University of Westminster, and Co-director of the Westminster International Law \& Theory Centre. He tries to limit his research interests but fails. They include law and space, critical autopoiesis, Continental philosophy, law and literature, gender studies, law and art. His edited volume Law and the City (2007) and his monographs Absent Environments (2007) and Niklas Luhmann: Law, Justice, Society (2009) are published by Routledge. 
Alain Pottage is Reader in the Law Department of the London School of Economics. His research interests lie in intellectual property (with particular reference to the field of biotechnology), theories of property, law and anthropology, and social theory. With Martha Mundy he edited the volume Law, Anthropology and the Constitution of the Social: Making Persons and Things (2004). 


\section{Series editor's preface}

The Law, Justice and Ecology series celebrates questioning the accepted, unsettling the categorical and re-engaging and re-imagining possible configurations and interplays of law and the contexts that it both shapes and is shaped by, or emplaced within. It is difficult to imagine a better flagship for the series than the book you hold in your hands, Law and Ecology: New Environmental Foundations.

The self-proclaimed ambition of Law and Ecology is to 'set up the foundations for a theoretically adventurous, politically radical, methodologically critical environmental discipline that combines law and ecology in a way that belongs solely neither to law nor to ecology'. The theoretically pioneering book in your hands is an invigorating incursion into the terrain at the heart of this series. The book is provocative and productively unsettling in its identification of a foundational void at the heart of contemporary environmental law. It is just as engaging in its construction of a less managerial, selfsatisfied, technicistic and impoverished vision of what environmental law can become. Challenging the legal illusion of control, in this case, control over the 'natural', this work focuses on carving out a space between law and ecology in order to present to us in full the paradoxical and idiosyncratic nature of environmental law and to construct, in short, a 'space' of 'critical environmental law' that engages with themes at the heart of this series: themes concerning animality, justice, spatiality, materiality and context, etc. Taking radical questioning as its starting point, the book bravely points towards the uncertainties and volatility of environmental law, reconceived in this work less as a discipline than as a transdisciplinary construction or an unfolding transdisciplinary event.

The book, in short, offers timely and vital encouragement to law's radical self-examination, for law to embrace its lack of stable or monolithic foundation, and to open itself expansively to the entire ecology within which law finds itself emplaced, that is to say, the 'disciplinary and ontological plane' on which law exists. Situating law in fluctuating space or spaces in 
which the human, the legal, the political, the economic, the scientific, the artificial, the animal and the environmental coexist and interpenetrate, it represents the perfect first publication in the series Law, Justice and Ecology.

Anna Grear 



\title{
Looking for the space between law and ecology
}

\author{
Andreas Philippopoulos-Mihalopoulos
}

\section{I.I Introduction}

This book is about a new critical environmental law. Its ambition is to set up the foundations for a theoretically adventurous, politically radical, methodologically critical environmental discipline that combines law and ecology in a way that belongs solely neither to law nor to ecology. While it is a fact that environmental law and ecology have been going through a co-evolution of sorts for the past few decades, ${ }^{1}$ it is also true that the majority of the literature dealing with the connection between law and ecology has been rather measured in its ambition and impoverished in terms of its theoretical credentials. It has remained content with assessing instances of the connection, usually associated with ecosystemic principles and management, while shying away from radicalising the connection and revealing its politically pioneer potential. While such an approach is useful and indeed fundamental for a newly socially and ecologically contextualised environmental law, its effect might prove counterproductive for a theoretical, as opposed to a normative, development of environmental law. It has indeed been noted by critics ${ }^{2}$ that the literature on law and ecology tends to emphasise how existing law already performs (relatively) well through the integration of ecological principles in its dealing with geographically determined, ecosystemically systematised areas of biodiversity, property rights, atmospheric pollution, and so on. The above approach, however, is often associated with two basic problems: first, it is tied up to an unadventurous normativity which, because of its goal-oriented attitude, rejects at the outset any theoretical links whose relevance to the existing law is not immediately evident. Second, the emphasis on ecosystemic organisation risks giving the impression of a rather facile managerial closure of the natural sphere and a corresponding ability of environmental law fully to achieve such management. In other words, the literature reproduces the problems of environmental law itself: short-term goal orientation and the legal illusion of control of the 'natural'.

The present book, therefore, institutes a break with the above undertheorised, goal-oriented, disciplinary-focused environmental legal perspective. 
Likewise, it will quickly become apparent that, here, we have not engaged with whether ecological principles and processes can, do or should apply to environmental legal thinking. Indeed, this has been successfully done elsewhere. ${ }^{3}$ Our endeavour instead has focused on carving a space between law and ecology in which to address the paradoxical and idiosyncratic nature of environmental law. Across the contributing chapters, this space is being referred to variably as critical environmental law, spatial and environmental justice, animality, heterotopia, radical encounter, and so on. The above spaces are not stabilised but volatile, they do not assert but doubt, they do not close the discipline but open up the whole notion of a 'discipline'.

The book constitutes an ambitious critique which at the same time encourages the law to look outside itself, over at new theoretical areas of influence; and look deeper into its own limited ecological position as simply another form of social expression alongside politics, economics, technology, science, and so on, which, however, is expected to make use of given legal notions and mechanisms. To this effect, ecology in this volume is understood in its broadest possible meaning as the disciplinary and ontological plane on which law finds itself. For the purposes of this anthology, we understand the law to be situated in this wider ecology, what I would call open ecology, that combines the natural, the human, the artificial, the legal, the scientific, the political, the economic and so on, all of which coexisting on a plane of contingency and fluid boundaries. ${ }^{4}$ In some respects, this is the real meaning of Barry Commoner's first law of ecology, namely that 'everything is connected to everything else'. ${ }^{5}$ We put forth a processual rather than value-based ecology and, to quote Deleuze and Guattari, 'we make no distinction between man and nature: the human essence of nature and the natural essence of man become one within nature in the form of production of industry'. 6 This makes our understanding of ecology legal, just as it makes our law ecological. The 'production of industry', that is the various elements that repeat themselves in nature and humanity in the form of processes/products is the focus of the present connection between law and ecology. Values that have led nowhere successfully so far, are now replaced by a study of the processes that transcend the usual dichotomy between human/natural. In this, we follow Guattari's conception of three ecologies, namely a 'mental, a natural and a cultural ecology': 7 nothing less then, than an ethicopolitical articulation of the connections between subjectivity, biosphere and society, ${ }^{8}$ in which the law finds itself floating about. This new, critical environmental law we attempt to sketch here can only situate itself along other disciplines in an open eco-logy and, in the process, both construct a new oikos (a 'home', eco-, from Greek oikos) that will embrace continuous material and conceptual movement; and, at the same time, a new critical language and rationality (-logy, from Greek logos, meaning both language and reason) that will address the complexity of the interconnection between law and ecology. 
But (and this is the coup of our approach) this situatedness is unhinged from traditional ontological and epistemological boundaries. This book is a product of the following realisation: that only some of the constituent elements of environmental law can be considered relevant for a new, critical environmental law. We are faced with a double paradox: on the one hand, a law that is both law and non-law, in the sense that it both employs the habitual legal mechanisms and processes in order to deliberate, and allows itself to be influenced, perhaps to a never before seen degree, by other disciplines; and, on the other hand, an ecology that does not focus on nature but on the absence of nature, and its replacement with a plane of contingency, whose articulations belong at the same time to the conceptual and the material, the 'human' and the 'natural'. As a result, environmental law is looking for its identity in an empty ecology, one with neither common language $(-\log y)$ between its parts, nor a home (eco-) about which to talk. The eco-logy in this volume signals the collapse of both the house in which environmental law is supposed to situate itself, and the language in which the law is supposed to communicate. Law as existing logos (language and rationality) is spectacularly discredited when faced with the challenges of environmental law: traditional legal dogmatics collapse before the idiosyncracies of environmental law, bastions of reason are replaced by floats of contingency, and trusted linguistic forms manage to attract vehement critique from feminists, ecologists, spatial theorists, autopoets, corporeal materialists and so on. ${ }^{9}$ In the same vein, nature as oikos has been demolished long ago, ${ }^{10}$ its death celebrated by a constructivism that allows little room for manoeuvring. "There is nothing outside"11 is bad enough, but 'there is no outside' is both worse and more accurate. To situate environmental law within this kind of draughty ecology requires a conceptual leap that neither traditional legal reasoning nor ecosystemic rationality can offer. This is a realisation that deviates dramatically from the current law and ecology literature, but one we think pivotal for the construction of a critical environmental law.

Thus, the task of a critical environmental law is to work along its connection with ecology, indeed within this open ecology of disciplinary and ontological fluidity, and construct a new language in order to communicate about this new home. The challenge is multiple, not least because this language can no longer be 'just' a language but rather a performance of wholehearted embracing of materiality. It is not coincidental that environmental law is the most readily available means to drag law outside its linguistic ivory tower and land it on the material, the social, the corporeal, the gendered, the spatial, the animal, the molecular. These are the inhabitants of the new home for environmental law: no longer based on the distinction conceptual/material, environmental law becomes one with its ecology, one gesture amongst so many others, trying both to define itself and carry on with its job of protecting its home. 
It is clear from the above that we believe in the need to push further the theorisation of the connection between law and ecology. The contributors in this volume have employed theoretical currents and constructions whose relevance for environmental law may not always be immediately apparent, whose role in a 'planet-saving' mission may not be so central, whose contribution does not amount to a blueprint for action. This is of course not a failure. On the contrary, we believe that the above-constructed emergencies have reduced environmental law to mere reaction rather than thoughtful action, to patching up rather than taking a step back and then throwing itself in, and indeed to a not so qualified failure in terms of environmental protection. To a large extent, this is attributed to a lack of distance, both ontological and epistemological, from the processes and goals of environmental law. We rarely stop to assess, we have accepted as given a certain traditional legal thinking that remains too positivist for the complexity of environmental issues; we have unquestionably reproduced the human/natural division and even the anthropo/ecocentric distinction; we have looked into environmental law merely as law and not as the idiosyncratic transdisciplinary singular construction that is.

\section{I.2 A new critical environmental law}

For the above reasons, the need to theorise is imperative: environmental law needs both to develop its theoretical apparatus to a level comparable to that of other legal disciplines, such as constitutional law, family law or international law and their respective theoretical foundations; and to keep abreast with disciplines at least formally outside traditional legal boundaries but with which environmental law finds itself in a relation of direct connection and reciprocal influence. It is not an exaggeration to say that science, geography, gender studies, development studies, sociology, political theory, economic analysis, to name a few, are directly present in the majority of environmental laws, frameworks, decisions - in short, environmental legal thinking. No longer can the law barricade itself against other disciplines and if this is true for law in general, environmental law is arguably the most prominent example of such a change. There is no longer a clear-cut boundary between environmental law and, say, science. ${ }^{12}$ On the contrary, environmental law is constantly internalising scientific findings, correctly or incorrectly, and acts upon them. Science (at least the science used in the production of legal thinking) is part of environmental law. In that sense, it is of the utmost importance for environmental law to follow the theoretical developments in those disciplines and at least be aware of what is this thing that seems to be changing environmental law from the inside.

In epistemological terms, therefore, the present anthology attempts to deal with the double problem of, on the one hand, an undertheorisation of the connection between law and ecology; and, on the other, an absence of the 
kind of critical theorising that by now informs everything in and around environmental law. All the contributors in this volume have tried to address the former through the latter. Indeed, it would seem that critical theorising of the kind advocated here is the only possible theorising of environmental law at a time of fluid interdisciplinarity, increasing ecological risks and unparalleled technological advancements. The combination of these three factors is a most powerful and novel one, and characterises all levels of environmental legal thinking, be this local, national, regional, transnational or international.

But allow me to clarify that here we are not merely talking about the need to employ interdisciplinary methodologies, formulate ecological legal regimes, trace the conceptual movement between ecocentrism and anthropocentrism or even attempt a further legal integration of environmental ethics. These are all important issues that to a certain extent feed into existing environmental legal thinking, ${ }^{13}$ although more often than most by appearing briefly in the first couple of paragraphs of socially contextualised writings on environmental law and then calmly forgotten. Rather than reiterating the need for integration of the above, we are insinuating that there is something much more threatening nestled in the very heart of environmental law, a self-destructive movement that potentially contains a great deal of violence against environmental law (and consequently the environment) itself. This is a multiple problem: we are currently witnessing that environmental law is rapidly losing a battle of self-definition, of indeed identity formation amidst threats of, first, politico-economic co-optation and, second, epistemic fragmentation.

The first kind of threat belongs to the field of ontological understanding of the discipline ('What is environmental law?'), while the second to an epistemological understanding ('Is environmental law a discreet legal discipline?'). Still, the two threats are clearly linked, not only in the way they are deployed but, more important, in terms of a potential defence against them. In short, this book essentially argues for a solid ethical orientation of environmental law that will enable it to resist both political co-optation and disciplinary fragmentation. Such an ethical orientation, however, can no longer come from a habitual employment of environmental ethics. ${ }^{14}$ While this remains important, it is also culpable of misguiding expectations that society may have had of environmental law. To put it bluntly, environmental law cannot save the planet. What is more, society cannot expect environmental law to want to save the planet. As Keith Hirokawa writes, although from a perspective that the present author does not share, 'deeply held beliefs alone are ill-equipped to achieve progress in environmental law'. ${ }^{15}$ And this is perhaps the crux of the problem and indeed the main challenge that the present anthology is facing. For, although environmental law is required to position itself amidst the ecology of unbounded disciplines, non-linguistic materiality, dead nature, human/natural/artificial hybrids and looming ecological disasters; 
at the same time, and after all its disciplinary excursus, environmental law must always return to the employment of a legal language and house itself in courts. Just as within the dissolved boundary between the human and the natural, there always remains a difference that emerges across temporalities and observational positions, ${ }^{16}$ in the same way there is a difference between environmental law and this wide ecology.

However innovative the processes employed by contemporary environmental law, the latter remains a law, still using norms and norm-producing processes, jurisdictional boundaries, temporal limitations. It also remains broadly adversarial, even in its newer forms of market-based mechanisms, regulation and mediation. (There is always one that dictates and the other that resists, there is always power involved in whatever configuration one may care to conceptualise it.) Which means that environmental law's margin for ethical ecological considerations and any desire to 'become-other', as Deleuze and Guattari would have it, is still inscribed within legal processes. These processes have on their side a tried and tested sedimentation, facility of application, path dependence, and indeed the burden of social expectations as to what the law can and should do. There are good reasons for which these processes have remained relevant across time, and it is not our purpose to discredit them. Rather, we aim at fully facing the foundational paradox of environmental law, namely its residual inscription within the boundaries of legal science and its putative gesture towards a radical extradisciplinarity. For environmental law is different. It is not just law (to the extent that there is such a thing as just law). It constitutes the clearest example of law in postmodernity, faced with insurmountable dilemmas that range from cultural relativism to decisions about life and death in a biopolitical context and projected temporalities and future risk of nanotechnology. As Brooks writes, 'a complete re-examination of current environmental law might ... [operate] not only as a preface to environmental law, but as a preface to the understanding of all law'. ${ }^{17}$ This is precisely the challenge that this volume is trying to address: how, while remaining within relatively given legal boundaries, environmental law can transcend its conservative limitations and assume a radical stance that will not be co-opted by political and economic interests. To put it differently, the main objective of the anthology is to imagine an environmental law that is equally at home in law and outside of it.

\section{I.3 The chapters}

The contributions attempt to accommodate the various, often paradoxical needs of environmental law. The quest of identity is sometimes articulated in terms of its disciplinary loyalty to existing legal mechanisms, and sometimes in terms of its productive confluence or even conflict with other disciplines. In all contributions, however, there is an underlying articulation of the 
importance of balancing out its 'internal' and 'external' demands, namely legal 'proper' and extradisciplinary ones, and a general, albeit critical, faith in its potential. It has to be noted though that this balancing out is not a hark back to a nostalgic image of natural balance, where law finds its position in a harmonious universe. On the contrary, conflict between these demands, and consequently between law and ecology, appears all the time as yet another manifestation of how the old semantics of ecocentricity can no longer be of any help. With this renewed interest in all things legal and ecological, the contributions to this volume aim at sketching the foundations of a new legal environmental discipline.

As a continuation of this introduction, the first chapter aims to develop further the underlying aim of the volume, namely the production of what can be called Critical Environmental Law. Situated in the open ecology of unhomeliness (no all-encompassing oikos) and miscommunication (no unifying logos), I attempt to establish environmental law's foundational paradox: that its conceptual limits are both potentially all-inclusive (since every societal problem can be seen as more or less environmental) and devoid of any content (since environmental law can no longer distinguish its 'object', namely environment per se). In that sense, environmental law rearticulates the problem of the connection between the universal and the particular. The traditional imaging of the environment as the thing that turns (French virer) around a stable pivot (a distilled sense of pure humanity) has been discredited in view of the collapse of the boundaries between the natural/human/artificial. In order to address this permeability, environmental law has the opportunity and responsibility to construct an adequate theoretical base for its role in environmental protection. The chapter argues for four critical environmental positions that are necessary for environmental law's attempt at catching up both with other disciplines, and the demands made to it by an ever-changing ecology. Thus, first, environmental law must theorise itself as acentric, namely conceive of itself as only one amongst a multiplicity of perspectives, none of which could ever be central (yet all of them claiming precisely that); second, environmental law must de-individualise the individual and position the human in an ecological plane beyond anthropo/ecocentricity; third, environmental law must relinquish the (traditional ecological) ideal of unity and accept uncertainty as a structural and constantly present inevitability rather than an invisibilised externality; and fourth, environmental law must move beyond the illusionary construction of prescriptive idealities and focus on a measured legal description of its own limitations. Largely following a critical reading of Niklas Luhmann's theory of autopoiesis, and influenced by postecological, feminist, spatial and other radical theoretical writings, I attempt to carve a space of critique simultaneously within and outside environmental law, a mirror of ethical responsibility against which the law can measure its potential, its limits and ultimately its objects of desire. In effect, critical environmental law 
is an acentric, postecological, manifold and self-aware 'thrown-together' of events and spaces which become 'solid' and relatively permanent through repetition.

Bettina Lange's chapter maps the current critical environmental scene with inspired lucidity. Since critical environmental law scholarship is not a coherent, hegemonic project with determinate legal obligations, Lange attempts to look into its principal influences, which she then categorises as external and internal critiques of the law - the former coming from critical legal studies and the latter from socio-legal studies. They both aim at destabilising the usual liberal theoretical foundations of law's autonomy especially in relation to the political sphere, while determining its limits as a tool of environmental regulation. According to Lange, critical environmental law asks further core questions, such as how environmental law stabilises or disrupts existing social orders, and how existing social orders can be transformed in order to achieve more sustainable forms of living. As a result, critical environmental law contextualises itself in the intersection between politics, economics and the law, situating thus itself within the wider ecology of social relations, subjectivity and sustainability needs. Lange's critical space between law and ecology is determined by what she calls a 'Foucauldian-inspired discourse analysis', namely a theoretical approach that can be associated with empirical research techniques, and as such not a grand systematic methodology. Lange applies the basic Foucauldian tenet of discursively constructed agencies and institutions to the specific area of EU administrative authorisation of transgenic agricultural products. This approach helps transcend essentialist conceptions of actors, institutions and practices, reveals the inbuilt ambiguity of the scientific and legal discourses, and allows an impressive possibility for the analysis of emotion discourses and their undercurrent impact. This approach claims not to marginalise the material by reducing the social world to language, but, based on analogy, it studies the material as analogous to the linguistic. In this sense, Lange's work addresses the main challenge of this book, namely the critical task of situating the law in a multidisciplinary, processual ecology in such a way that the law both engages with its environment in an 'illimitable' way and at the same time remains a contained, limited entity.

After starting with an overview of the traditional understanding of law and ecology as the marriage of the two different rationalities of the ecosystemic and the legal, Jo Goodie quickly broadens the scope of what is considered ecological. Her chapter focuses on the ethical import that instability, variability and uncertainty have for the critical environmental legal discourse, thereby expanding both the concept of the ecological and that of the environmental legal (to include science, subjectivity, common sense, social values, morality, cultural conceptions and so on). Goodie presents an impressively multifaceted understanding of toxic risk litigation that draws from the literature as well as her personal experience as an Australian 
plaintiff's solicitor in the field of toxic tort litigation. Beginning with the haunting proclamation that 'legal understanding of the environment is contingent', the author builds a meticulous classification of the way in which environmental hazards are legally interpreted in toxic tort claims. She constructs four (non-exhaustive) categories of legal interpretation of toxic risk: insurantial, scientific, clinical and commonsense. Through an elaboration of the above Goodie shows how, in the current ecological (in the broader sense adopted here) context, the law struggles within itself with a host of differentiated and often incompatible rationalities that must perforce converge into the delivery of a court decision. This multi-factor approach distances itself from simple causality and even probabilism and enables the court to construct a moment of decision where the various rationalities simultaneously underpin and obstruct each other. The process demonstrates at the same time the resilience of the law (in its guise as environmental law) to remain law ('a disinterested, yet authoritative, arbiter on risk') by successfully integrating the vocabulary and techniques of risk calculation; and the inability of the law to distance itself from imparting blame and indeed guilt in the form of punishment for people who are judged to be inadequately risk-aware and risk-averse. The last feature is a symptom of the law's assimilation of the common sense (whose common sense?): as Goodie writes, the ubiquitous vocabulary of risk has replaced the notion of sin, and the court feels entitled to ascribe moral culpability to the 'irresponsible' while deculpabilising the 'victim'.

When John Paterson begins his chapter on the precautionary principle by quoting the reaction of the French Academy of Science condemning the proposed constitutional incorporation of the principle as 'catastrophic', he points precisely to the paradox of the precautionary principle as an ambitious but by definition ambiguous principle that floats in an ocean of differentiated perspectives, conflicting interests and levels of implementation and judicial control. Paterson delivers a step-by-step analysis of the status of the principle, first, as scientific; second, as operational in terms of policy; third, as justiciable; and fourth, as relevant in terms of practical consequences. Drawing on philosophy of science and systems theory, Paterson builds a test of plausibility of the hypothetical harm and reasonableness of the proposed response, that attempts to accommodate both societal and judicial uncertainty, while retaining the fluidity yet relevance of the principle. In that sense, Paterson's chapter addresses the space of uncertainty that characterises contemporary environmental jurisprudence that finds itself in the cusp between science, regulation, economy and legal demands. Thus, the principle is found to be 'scientific' - with all the caveats that such an epithet entails - since it entails decisions made under conditions of ignorance. It can also be made operational, provided that the difference between the various systems that have a stake in such a decision (such as law, science, politics, economy) is internalised by each system as an observable ignorance, namely as a thing 
that cannot be fully understood by any system, yet this inability of full understanding is taken into consideration by each system as a positive and calculable value. Paterson illustrates the above in a detailed analysis of judicial decision-making as it appears in the European Court of First Instance case of Pfizer Animal Health SA v Council, which results in observing both the difficulty that the law has in distinguishing between risk and ignorance, as well as its difficulty in handling the boundary between procedural and substantial matters, which becomes particularly subtle in cases of potential precautionary principle application.

Alain Pottage treads an alluring ground of paradoxical ecology by focusing on the interfolding of material and instrumental technologies in the context of the regulation of biotechnology. In a Luhmann/Deleuze-inspired text that is equally at ease with the multiple ecologies of this volume and, impressively, with the technicalities of GMO, Pottage offers a future-arresting, almost prophetic account of the way in which biotechnology affects sociality. The text begins with the way in which biotechnological artefacts, such as GM crops, become the actual means rather than simply objects of environmental regulation, and specifically the Transcontainer. This aptly named regulatory instrument aims at developing GM crop plants that are biologically contained through the inscription, into the very texture of the plant, of its genetic tracing (namely, its identificatory event, its 'birthmark' as it were) and its temporal containment (in the sense that the yield of the particular seeds are limited in order for the farmer to return every time to the seed producer for more). The author questions the EU policy of crop coexistence, not merely on the usual grounds of economic expedience but significantly on account of its policy of tolerance of 0.9 per cent 'adventitious' GM content in what is otherwise considered (and, importantly, labelled as) nonGMO. It becomes quickly obvious that the difference between GMO and non-GMO is one of degree rather than one of kind. This is only part of the broader coexistence initiative that employs the already well digested collapse between the 'artificial' and the 'natural', or in this case the 'grown' and the 'made', and observes it (interprets it/uses it) as an always already occurrence. This legitimising realisation augurs what Pottage calls the 'regulatory ecology' of a material and regulatory assemblage that does not distinguish between categories of being (GMO/non-GMO) but between methods. These remain open to a multiplicity of interpretations that differ radically between actors and discourses, such as those of the politician, the campaigner, the producer, the distributor, the testing agency and the consumer. A related and equally fascinating side of coexistence brought forth in the text is the way the spatial (in the form of crop segregation and buffering) coexists with the genetic containment in this complex ecology of landscape/human factors/ economic vectors. This spatiality, however, is bound to be minimised in the face of increasingly more efficient genetic containment - and this posits the question: how irreversible and indeed how 'alien' will future forms of this 
paradoxical ecology be? An ecology already with us and somehow never fully here, never fully apprehended and certainly never even remotely 'contained'.

Karen Morrow's contribution continues the critical environmental project by developing the ecofeminist perspective with a view to a truly inclusive polity. Morrow's approach is neither narrowly feminist, nor narrowly ecological, but open in its inclusiveness and ready to embrace broader understandings of ecology and gender. In that sense, Morrow's contribution stands squarely within this book's critical ecological project of locating the law in the plane of ecological processes and offering perspectives that attempt to revolutionise concepts of inclusion. Her chapter begins with an analysis of the WCED Brundtland Report in terms of its 'partnership' approaches to governance and civil society participation. While this is welcomed, it has admittedly led to some issues, such as the overreliance on NGOs in terms of their presumed ability to talk for the people, as well as the possibility of the public delegating both responsibility and activism to professional NGOs. This is hoped to be counteracted by an emphasis on a more inclusive participation agenda, which shall be highly political, knowledge-based and embodied. Morrow's inspiration comes from the work of Lorraine Code, whose concept of ecofeminism refers to a broad church indeed. Code's 'ecological thinking' includes the traditional ecofeminist goals of identifying and tackling patriarchy, but goes beyond that by developing practices, policies and theories which are not male-gender biased, and which look at humans as ecological beings. In that sense, Code's project includes inclusive decision-making processes and a strong critique of scientific certainty. To that, Morrow adds the practice of what she calls 'quotidian epistemology', namely an embodied, evidencebased body of observations that will help produce ecologically informed, inclusive decisions. Morrow remains a believer in resistance movements against the given power- and control-based rationality, and the chapter urges us to think precisely of such possibilities.

In an incantatory mode, Piyel Haldar talks of future, salvation, sovereignty and exception as observed through a scholarly and often lyrical study of Christian bestiaries, namely catalogues of both actual and imaginary animals employed in Christian literature in order to educate the faithful. Haldar situates environmental law in a legal, philosophical, cultural, religious and scientific textual omniana, trying in this way to establish the particular sovereignty that determines the nature of environmental law. Two apparently competing sovereigns emerge: nature, or as Haldar calls it, 'a sort of green sovereign that emerges from the earth itself', and the Law, who appears and eventually reverses the sovereignty of nature over man. With the Law, nature is excised and in its place a sovereign environment is installed - this is what the author calls the passage from 'the verdant to the desiccated'. The environment now needs the law to order and maintain the distance between man and nature. Nature is thus reduced to a cipher for the law, a sort of resource 
for the perpetuation of man's higher position. This primacy of law over nature, argues Haldar, is rooted in a Christian hermeneutic that constructed a logos, by inception higher than animality. Indeed, it is precisely this kind of Christian religious thinking that turned man against nature, thus establishing the primacy of law over nature. The need for deciphering nature in order to maintain the primacy of law becomes abundantly clear in the examples that Haldar employs from a range of bestiaries that span the post-pagan to the later medieval, and include natural histories, mystical zoography, general animal symbolism, as well as werewolves, unicorns, onocentaurs and jacalus. But the end purpose of deciphering both the actual and the fabulous becomes quickly apparent: through the didactic construction of man's normative behaviour towards his environment, the bestiaries present the only way of future salvation. This is the paradox of animals, at the same time subservient to the law and without original sin. This paradox, like the donkey leading Christ into Jerusalem, leads man to salvation. In that sense, nature's subjugation is presented as the necessary and justified means in the face of a known, mapped-out future that promises redemption. Bestiaries, therefore, are not unlike environmental law, which looks with hope into an all-justifying future point of salvation, while consuming itself into all sorts of present exceptions.

Antonia Layard and Jane Holder weave an intricate conceptual, spatial and social canvas on which they rehearse their main preoccupation with the conceptualisation and application of Environmental Justice. Their chosen political/legal/spatial context is the European Union, and their conceptual tools are the EU notions of solidarity and territorial cohesion. What appears as mere background, however, takes centre stage in the authors' attempt to sketch a different, spatially defined, ecologically just environmental law. In that sense, their project of bringing forth environmental justice through the two legal tools of solidarity and territorial cohesion is a remarkable addition to an ecologically situated law, indeed a critical environmental law. Beginning with a rather measured claim that location should not be a disadvantage, which the authors consider to be the common core of the above concepts in the context of the EU, the chapter proceeds with a profound understanding of both the practicalities and the theoretical potentialities of a European environmental law that goes beyond the rhetorical and actively engages with the specificities of a locality. Indeed, the spatial situatedness of environmental law and the related struggle for spatial justice is one of the pivotal notions of the argument. This, coupled with the relatively new and inchoate concept of territorial cohesion opens up avenues of questioning and re-evaluating of the relation between space and territory. Is there a European territory of the kind that would imply a stable and agreed model of European society? Does it transcend national or even physical boundaries? Can environmental law meaningfully limit its application to such boundaries, or must it expand by applying a different, non-causal understanding of locality 
(as some recent court cases seem to be pointing at)? Where does the ethical obligation for solidarity between member states stop? Balancing between a realistic stance ('There is no imminent prospect of an Ecotopian state') and a critically radical position ('This more holistic, integrative approach to cohesion is clearly compatible with a philosophy of social environmental justice'), the chapter eventually closes in on the importance of a spatially embedded social legal presence that takes advantage of, while at the same time spearheading the quest for the European holy grails of integration and harmonisation. From normative to descriptive, environmental justice is a measurable potentiality and one that can become central to territorial cohesion and solidarity.

Andreas Kotsakis's contribution focuses on Foucault's idea of heterotopias, namely 'the dark underbelly of utopias': as opposed to what utopias are often considered to be, namely places of unquestioned order, heterotopias are actual, lived-in places of unsettling, anti-foundationalist critique, rife with uncertainty, discontinuity, difference. Through the three heterotopic environmental instances of natural reserves, local communities and ethno-botanical institutions Kotsakis constructs a 'heterotopology', that is, a method of analysis of space that takes into account the need to construct a critical environmental law in the face of law's spatial turn. For this, the author follows Foucault's famous proclamation that 'the present epoch will perhaps be above all the epoch of space' and rides along the quest for a spatially aware environmental law that will finally open up and attempt to understand spatial juxtaposition, superposition, simultaneity and dispersion as determining parts of environmental legal thinking itself. Along that vein, Kotsakis assembles an ecological canvas of multiple locations, inhabitants, narratives, discourses and processes, on which he attempts to situate his vision of a critical environmental law. Heterotopy proves to be an invaluable tool to apply the kind of critique that takes nothing for granted. Thus, natural reserves constitute what the author calls 'crisis heterotopias', namely the salvaging space, not so much of nature, but of an incessant global urban development that is enabled to carry on 'elsewhere'. Or ethnobotanical institutions, much favoured by current biodiversity regimes, that are found to be 'heterotopias of deviation' and in which only the stakeholders in conservation and development are admitted, rather than right holders, property owners or raw material producers. And finally, sustainable communities - the golden cudgel of the era of sustainability - which are seen as yet another heterotopia of deviation, this time freezing rural identities that obey a logic of nostalgic relics on which global economic growth blossoms. Perhaps the most important offering of environmental heterotopias is their ingrained memory of all these narratives that sooner or later fall out of favour - all the more important since heterotopias remain lived-in places. And as Kotsakis writes, 'a failed place is harder to hide than a failed legal agreement'. 
Mark Halsey's chapter is a widely ranging lament for the loss of nature through legal, political and economic partitioning. Based on Gilles Deleuze's theory, but with important insights from Foucault, Virilio and others, Halsey examines world heritage areas and big protected trees as manifestations of the divide between what is worth preserving and what can be disposed of. This is the legal divide between, on the one hand, protected areas and species, and, on the other, all other spaces and beings not deemed worthy of legal protection. In what reads like a gallery of rogues, Halsey describes how the world is partitioned into categories of varying protection value, thereby bulldozing over what Deleuze calls 'the difference borne by the individual', namely each being's irreducible, never to be repeated difference. By designating a national park or a big tree an object of legal protection on account of its individuality, the law denies the importance of all other parts of nature as excess. This is what Halsey calls an 'encounter' with the 'monstrous': when faced with the protected giant tree, one encounters something 'both magnificent and abhorrent', both splendid in its individual difference and monstrous in its violence of presence, which relies on the perdition of millions of other trees not deemed worthy of protection. Such encounters force us to think beyond the boundaries of given thought, pushes us into the 'acategorical', the one that cannot be contained by either law or the representation of nature as a categorisable, legally manipulated object. And through its legal designation, the 'monstrous' retains its sovereign, exclusionary power to marginalise everything else that either comes under its own category (something like Noah's ark, where one specimen of every species is to be saved), or under any other, not 'important' category. Halsey deals with several intertwined themes of conceptions of the 'social' and the 'natural', of the various truth discourses, of the difference between the geological and the industrial speed; but at the end, like Deleuze, he returns to a plane of ecological immanence where the difference becomes both unique (for each being/space/discourse) and somehow obsolete (since the boundary between the natural and the human/artificial has collapsed).

\section{Notes}

1 Brooks et al., 2003; Turgut, 2008.

2 See Hirokawa, 2002: 225, who notes that the literature 'seeks to alter the shape and operation of environmental law by making legal arguments that already existing law compels the proposed changes'. This is generally a North American approach to law and ecology, and one that is explicitly focused on mainly US jurisprudence.

3 Brooks, 1991: 13.

4 The idea of ecology put forth in this book, although conceptually not necessarily subscribed to by all contributors, is directly influenced by Guattari's, 2000, notion of ecologies, as well as his work with Deleuze, 1986, 1987. According to this, ecology does not refer to the science of ecosystems but to the plurality of machinic assemblages that construct the plane of immanence. This understanding of ecology embraces the technological, scientific, natural, human, artificial, and so on, not only 
without differentiating, but purposely dissolving the distinctions. Although such inclusive ideas have been successfully rehearsed in the wider ecological debate (e.g., Baarschers, 1996: 14, who equates ecology with 'an attitude, a world-view'), there is a difference between a vaguely or even contextualised ethical/ecological view, and the kind of ecology that combines the material and the conceptual without distinction and transversed by continuous movement. For two excellent contributions to the connection between Deleuze and ecology see Herzogenrath, 2008, 2010.

5 Commoner, 1971: 33.

6 Deleuze and Guattari, 1986: 4; in that sense, one can talk about ecophilosophy see Papuzinski, 2009.

7 Guattari, 1995: 20.

8 See Genosko, 2010, for an excellent analysis.

9 See indicatively Verchick, 2007; Delaney, 2003; Holder and McGillivray, 1999; Cairns, 2003; Tarlock, 2004. This is more than a 'Galileo problem' as Cassuto, 2004, puts it, namely that the environment or indeed environmental law could ever affect a pretence of objectivity. For even when environmental law is forced to affect precisely such a pretence its effect becomes all too apparent.

10 Merchant, 1980.

11 Lyotard, 1993.

12 See Adelman, 2008.

13 See for example, Gorovitz Robertson, 2008.

14 Although innovative applications of environmental ethics do promise a certain, if not way out, at least way of seeing things differently. This is perhaps the greatest contribution of environmental ethics. On its own, however, it is unable to deal with the kind of increasing uncertainty present in environmental law, not least because of its continuing reliance on a human nature that can be changed from within and according to ecological urgencies. It is characteristic, for example, that Christopher Stone's, 2007, observations on ethics and international environmental law conclude with the following, rather disheartening to the present reader, sentence: 'Ultimately, international environmental ethics may be less about human welfare or even the environment than about the unavoidable molding of ideal human character.' If even at the arena of international law, arguably the least human-centred legal discipline, the focus of ethics remains the ideal human character, it seems obvious that the connection between ethics and contemporary concepts of agency is still far away.

15 Hirokawa, 2002: 227.

16 This is a difference not between subject/object but between observer/observed, and even that only at specific moments when the distinction is momentarily frozen. This is what Hanjo Berressem, 2010: 70, in his excellent hybrid language of Deleuzian and autopoietic topologics, calls 'radical paradoxical logic'.

17 Brooks, 1991.

\section{Bibliography}

Adelman, David, 'The art of the unsolvable: locating the vital center of science for environmental law and policy', 37 Lewis and Clark Law School Environmental Law Online 3, 2008.

Baarschers, W. H. B., Eco-facts and Eco-fiction: Understanding the Environmental Debate, London: Routledge, 1996.

Berressem, Hanjo, 'Structural couplings: radical constructivism and a Deleuzian ecologics' in Bernd Herzogenrath (ed.), Deleuze/Guattari and Ecology, Basingstoke: Palgrave Macmillan, 2010. 
Bodansky, Daniel, Jutta Brunnée and Ellen Hey (eds), The Oxford Handbook of International Environmental Law, Oxford: Oxford University Press, 2007.

Brooks, Richard, 'A new agenda for environmental law', 6 Journal of Environmental Law and Litigation 2, 1, 1991.

Brooks, Richard, Ross Jones and Ross Virginia, Law and Ecology: The Rise of the Ecosystem Regime, Aldershot: Ashgate, 2003.

Cairns, John, 'Sovereignty, individuality and sustainability', Ethics in Science and Environmental Politics, 71-7, 2003.

Cassuto, David, 'The law of words: standing, environment, and other contested terms', 28 Harvard Environmental Law Review, 79-128, 2004.

Commoner, Barry, The Closing Circle: Nature, Man, and Technology, New York: Knopf, 1971.

Delaney, David, Law and Nature, Cambridge: Cambridge University Press, 2003.

Deleuze, Gilles and Félix Guattari, Anti-Oedipus: Capitalism and Schizophrenia, trans. R. Hurley et al., Minneapolis MN: University of Minnesota Press, 1986.

Deleuze, Gilles and Félix Guattari, A Thousand Plateaus, trans. B. Massumi, London: Athlone Press, 1987.

Genosko, Gary, 'Subjectivity and art in Guattari's The Three Ecologies', in Bernd Herzogenrath (ed.), Deleuze|Guattari and Ecology, Basingstoke: Palgrave Macmillan, 2010.

Gorovitz Robertson, Heidi, 'Seeking a seat at the table: has law left environmental ethics behind as it embraces bioethics?', 32 William and Mary Environmental Law and Policy Review, 273, 2008.

Guattari, Félix, Chaosmosis: An Ethic-aesthetic Paradigm, trans. P. Bains and J. Prefanis, Bloomington IN: Indiana University Press, 1995.

Guattari, Félix, Three Ecologies, trans. Ian Pindar and Paul Sutto, New Brunswick NJ: Athlone Press, 2000.

Herzogenrath, Bernd (ed.), An [Un]Likely Alliance: Thinking Environment[s] with Deleuze|Guattari, Newcastle upon Tyne: Cambridge Scholars, 2008.

Herzogenrath, Bernd (ed.), Deleuze|Guattari and Ecology, Basingstoke: Palgrave Macmillan, 2010.

Hirokawa, Keith, 'Some pragmatic observations about radical critique in environmental law', Stanford Environmental Journal 21, 224-81, 2002.

Holder, Jane and McGillivray, Donald (eds), Locality and Identity: Environmental Issues in Law and Society, Aldershot: Ashgate, 1999.

Lyotard, Jean François, Political Writings, trans. B. Reading and K. Geiman, Minneapolis MN: University of Minnesota Press, 1993.

Merchant, Catherine, The Death of Nature: Women Ecology and the Scientific Revolution, London: Wildwood House, 1980.

Noss, R. F., 'Some principles of conservation biology as they apply to environmental law', Kent Law Review 69, 893-909, 1994.

Papuzinski, Andrzej, 'The idea of philosophy versus eco-philosophy', 4 Problems of Sustainable Development 1, 51-9, 2009.

Stone, Christopher, 'Ethics in international environmental law', in D. Bodansky et al. (eds), The Oxford Handbook of International Environmental Law, Oxford: Oxford University Press, 2007.

Tarlock, D., 'Is there a there in environmental law?', 19 Journal of Land Use 2, 213-54, 2004. 
Turgut, Nukhet Yilmaz, 'The influence of ecology on environmental law: challenges to the concepts of traditional law', 10 Environmental Law Review 2, 112-30, 2008.

Verchick, Robert, 'Katrina, feminism, and environmental justice', 13 Cardozo Journal of Law And Gender, 791, 2007. 


\title{
Towards a Critical Environmental Law
}

\author{
Andreas Philippopoulos-Mihalopoulos
}

\section{I Introduction}

On the one hand, environmental law encompasses, actually or potentially, everything that may ever be encompassed by law in general. On the other hand, and simultaneously to the above, what we commonly refer to as the legal discipline of environmental law does not really exist. These two seemingly contrasting propositions, namely both non-existence and all-inclusiveness of environmental law, are one and the same thing. What seems mere sophistry, is actually, I argue, the foundational paradox of environmental law. With the boundary between human and environmental/natural collapsed, environmental law is left in a limbo of indifference (what would be its point?) and allinclusiveness. The repercussions of such a paradox go beyond the rhetorical and touch upon the delineation of the field of environmental law, its object and objective, its limits and most importantly, its limitations. The paradox and its repercussions are the focus of the present chapter. However, I do not attempt to resolve the paradox, find a way out of it or indeed clarify the conceptual area in which environmental law applies. On the contrary, the purpose of this chapter is to expose the paradox and build on it. In so doing, I am conscious of the fact that I am making environmental law's work harder. I want to think that I render visible a complexity that is consistently marginalised by environmental law's mainstream theoretical and applied attempts, and expose the limitations of environmental law as well as its weighty and in some respects unique responsibility.

This is a strategic move. Amidst the tension between the opposing and rather aggressive sides ('environmental-law-includes-everything and environmentallaw-does-not-exist'), I want to carve a space for what I call Critical Environmental Law. This space must remain a space of tension and self-generating undecidability, nowhere permanently anchored and flirting equally with the all or (better: and) nothing of environmental law. The term 'space' is meant in the most literal sense possible. It is an actual space of critique within environmental law, which situates itself away from barren debates on anthropocentricity versus ecocentricity, proof of causality, measurements of 
harm and even differing prioritisation of temporalities (present versus future generations). Instead, the space of Critical Environmental Law is grounded on three 'catching up' necessities, namely three issues in which environmental law lags behind other disciplines and in which it needs to catch up if it wants to retain its relevance: first, the need to 'decentre' environmental law and to construct a theoretical approach that will not succumb to the usual hierarchical centralising but will wake up to its possibility of functional acentricity; second, the need to accept the fragmentation of environmental law with special emphasis on the collapse of the human as an individual (namely, undivided) and its replacement with hybrid connections between the human, the natural, the spatial, the artificial, the technological; and, third, the need to land environmental law on a theoretical grounding of difference rather than unity. These three elements define the way in which Critical Environmental Law is to be shaped and practised. In what follows, I attempt to sketch those elements within the context of environmental law, and relate them in particular to the theory of autopoiesis, namely the sociological theory developed by the German theorist Niklas Luhmann. This is with a view to show that environmental law is a potentially decisive tool in these new turnings and tidings we are currently witnessing, and that such an opportunity is accompanied by a deep responsibility. To address this, environmental law is in need of radical theoretical elaboration. In this respect, autopoiesis represents an ideal if rarely suggested bedfellow for environmental law. Before that, however, a brief explanation of why I consider that in the heart of environmental law there lies an unsolvable paradox.

\subsection{The paradox of environmental law}

To start with the bravado of the type 'environmental law does not exist' is not a denial of the existing body of legislature and jurisprudence that deals with environmental causes. Rather, it points to the impossibility of defining any cause as environmental in a manner that would exclude claims from other branches of law. In support of this, it has been said that environmental law is not an organic mutation of the common law, or more generally, the western legal tradition ... As a result, environmental law remains largely unintegrated into our legal system; thus, it is vulnerable to marginalization as support for environmentalism ebbs and flows'. ${ }^{1}$ Its reliance on environmentalism aside, environmental law remains a sui generis branch of law, hazy yet urgent, undefinable yet omnipresent. Take a simple example: pollution is variously claimed by property law, landlord and tenant law, planning law, public law, commercial law, intellectual property law, criminal law, administrative law, and then regional and international law, European Union or federal law, civil law, financial law, regulation, policy, soft law, agendas and declarations, preambles and protocols. And of course by environmental law too. But does anyone else apart from environmental lawyers care about 
this categorisation? And if so, is this just an identity quest for the lost girls and boys of the environmental legal lobby? Please indulge for a moment my suspicion that there is something else, a tad more important at stake here.

The other side of the same problem is an overcompensation in terms of claims of problems on behalf of environmental law in order to make sure that eventualities are covered. This has the potentially useful but more often debilitating consequence of considering everything more or less environmental. It would hardly be out of place to suggest that everything can eventually be regulated by this conceptually expansive branch of law that swallows up large chunks of local, statal, regional, international and supranational legal agendas and is left wanting ever more. Arguably, this happens for good reasons. Environmental law is potentially the only law that in the current conditions remains 'relevant' - a relevance not only because of its close connection to the survival of the human species but also because of such issues as quality of life, health, poverty, gender equality, intra-personal relations, adequate housing, societal organisation, urban development, international commerce, and so on. But this means that environmental law potentially embraces every aspect of life that remains relevant to what really matters. The same can be put from the point of view of risk. Seen from one perspective, the advancement of technology equals the multiplication of risks, ${ }^{2}$ and if risk precaution is environmental law's most valiant radical representative, ${ }^{3}$ environmental law plays a potentially limitless role in the determination of 'acceptable' technology. And it would not be far-fetched to say that regulation of technological effects is to a large extent the main challenge of our society. Since technology increasingly mediates the relation among humans, and between humans and everything else (natural, artificial, technological) by even altering the connection between means and object of regulation, ${ }^{4}$ legal processes that can be considered environmental find themselves popping up everywhere with more or less intensity.

The same paradox can be put from the perspective of time: environmental law's temporality is one of a paradoxically imminent yet distant all-embracing horizon. Environmental protection matters tend to make their presence felt with unprecedented urgency, imposing deadlines concerning global survival, health and quality of life. While these present themselves in the present, they usually refer directly to the future. The temporality of environmental law is a hydrocephalous one, with the future weighing massively over present decisions the most obvious example of which is the concept of intergenerational equity. Such a distribution of juridical weight requires of environmental law unprecedented degrees of flexibility that are accompanied by an uncomfortably intense and counterproductive checking for consistency.

The reasons for this paradoxical dis/appearance of environmental law are multiple: environmental law is considered a relatively new, relatively uncrystallised legal discipline, whose limits are both more flexible and tested significantly more intensely than those of other legal disciplines. This is the 
direct consequence of the combination of inadequate epistemic distress and superabundant urgency: as yet there are few sustained attempts at the establishment of an extended, theoretically rich debate on the precise nature of environmental jurisprudential underpinnings. No doubt, this omission is also prompted by the idea that theory is counterproductive in the face of such acute and urgent problems. ${ }^{5}$ The paradox is accentuated by the intensely fragmented societal presence of environmental law: calls for reliably consistent responses come from social domains as diverse as science, transnational politics, global economics, ethics, environmental philosophy, geography, and so on. Take the example of sustainable development, a concept that incorporates the handling of the conflict between economy and environment from within the law. ${ }^{6}$ As a consequence, environmental law finds itself in a practical continuum with policy and regulation. This is supplemented by an extensive use of the concept of soft law which deliberately oscillates between binding and non-binding law. ${ }^{7}$ It is far from surprising, therefore, that environmental law provokes social reactions that range from support and fanaticism to indifference and hostility. It has to play along and resist (un)fashionable environmentalism, persistent economic weighing (and, equally, remuneration, since both protection of the environment and protection against the protection of the environment are lucrative), avid internalisation of environmental issues by the political system, unsettling internalisation of scientific uncertainty, ethical reflection that urges towards paradigm shifts of the kind established law is unable to perform, and so on.

Perhaps the most important reason for the perpetuation of the environmental legal paradox is its intense connection to science. ${ }^{8}$ The establishment of thresholds, for example, is only a minor theme compared with the formidable task of risk prevention in view of lack of exhaustive scientific information. The inherent necessity of environmental law - more than any other legal branch - to internalise scientific data demands ephemeral decisions and constant re-evaluation of already established problem-solving methodologies. The ephemeral nature of environmental legal decisions is further demanded by the role that economic considerations play in decision-making, in the form of technology transfer, exploitation of biodiversity, and pollution allocations, amongst other mechanisms. ' ${ }^{9}$ Environmental problems are characterized by the need to reduce their inevitable uncertainty through the constant generation and application of new knowledge. They often do not, as do many other areas of the law, display a repetition of similar fact patterns. ${ }^{10}$ However, it is not only the patterns that change. The scientifically recommended way of evaluating such patterns changes also. Environmental law is a showcase of Murphy's description of the future in the era of statistical positivisation: '[t]he future is reconstituted as inherently revisable statistical projections on a screen'. ${ }^{11}$ The in-built need for revision of statistics renders shaky the connection between present decision and future stability: 'it makes little sense to agonise over today's decision when it is likely to 
require revision tomorrow'. ${ }^{12}$ This, however, seems a major failure of environmental law, at least in comparison with other legal branches. Put from a temporal perspective, the main function on the law is to fix over time the expectations that society has of what is permitted and what is not. ${ }^{13}$ The inability of environmental law to deliver such certainty as adequately as other legal branches do, seems to target precisely the ability of environmental law to become or even to be law. However, I argue that environmental legal volatility and inherent uncertainty are not a malfunction: they are simply inalienable attributes in view of the irreducible complexity of environmental law's subject matter.

Thus, we have the paradox: environmental law is both a cut through other legal specialisations, itself undefined and undefinable; and inclusive of all other legal specialisations, claiming a space of direct or indirect 'integration' in every legal decision, and eventually mediating every relation between the human and whatever else is left on the other side. While this may under certain conditions be a paralysing predicament, I opt for the time being to leave it unresolved, in full tension and in rather febrile potential for the identity of both the discipline and its lawyers.

\subsection{What environmental law?}

Etymologically, environment comes from the word environs, in its turn coming from the French words en ('in') and virer ('to turn'). This implies an inside that stands erect and an outside that surrounds this inside and turns around it. ${ }^{14}$ Environment is the 'thing' that surrounds 'us', the dervish-like outside that whirls like a frilly skirt around a stable pivot. But the pivot remains not only stable, fixed and unyielding but significantly 'central'. This can imply only one thing: that one can do away with the frills and stick to the thing in the centre. This centre, however, is occupied by an impoverished understanding of the human form: divorced from the animal except in the form of dependence, separated from the artificial except as technological (rather than natural) evolution, distanced from any sort of hybridity except as monstrous aberration, the human in the centre is a theoretical distillation of such conceptual purity that one would be hard pressed to find anything comparable in the real world.

So it is the environment that is expected to skip and turn while the central theoretical construction, that of a purified human, remains imperiously stable. There are two fundamental problems with this formulation. The most obvious one is the implicit causality, where movement is understood as the precondition of stability. To put it differently, the turn is needed in order for the pivot to remain pivotal. The way the environment whirls around the human is a precondition for human centrality, indeed a resource (to use the environmental parlance when referring to the environment) for an adequate existence. In the eye of the storm, there is quiet. But there is no connecting 
transgression between the two: human and non-human, human and resource, human and nature. All mendacious dichotomies that betray a simplicity in conceptualising human nature. Where does human end and natural start? Where does technology begin being evolutionary? When are disasters natural?

The other problem revealed in the etymology of the word environment is the assumption of a centralised geography, one that understands the observer, the utterer, the actor (in other words, the parameters of locating the mode of locating) as the centre of the environment. The thematisation of the surroundings by the only one who has the linguistic ability to express difference (namely man, in the fullest gendered bias of the term) is reminiscent of Galileo's trial, where the earth had to be torn out of the centre of the universe, leaving an unbearable absence for the religious system of the era. ${ }^{15} \mathrm{In}$ Galileo's mind, the static centre was replaced by a movement. Eppur si muove! 'Yet it moves!' For a brief moment, the turning has rolled over and flooded the inside, making the latter collapse under its own gravitas. But, even out of the ruins, a local universe was established in its proper syntax of centre and surroundings: thus, 'our' anthropomorphic planets and 'our' sun. Order restored and stability re-established, albeit in a celestial body nearby. And with this example in mind, one looks for the centre.

But things are changing. ${ }^{16}$ Environmental considerations become integrated, environmental law is claiming a field, the purity of the human is strongly doubted. The environment is in a process of relocation, away from the periphery as the surrounding frills, and right on the gesture of transgression between human and natural. However, the reasons for the change may be less benign, less 'ecofriendly' than one would hope. It is not as if environmental law was born enlightened. It too has looked for its very own centre. But the quest has yielded nothing but a void, or better, a series of questions. Can the national valiantly occupy the centre? Would a move to the regional/ supranational/international prove more satisfying? Even more fundamentally, is really law in the centre of environmental law? Could one not argue with conviction that science, economy or even politics are in the centre of environmental legal decisions? And what about the centrifugal pulls of anthropocentricity and ecocentricity? The answer to these questions is deceptively simple: none of the above moves is in itself satisfying. So what is one left to do? Move away from the concept of the centre altogether. It is the case that environmental law has been pulling itself off the grand delusion of the centre from its very (non-)beginning, from the heart of its paradoxical foundation. And this pulling away would have been much more obvious and eventually successful if environmental law was not tied down to some traits that seem to characterise every legal discipline, such as the need for systematic unity, for binding decisions of the binary kind, for a reliable reproduction of societal expectations, for consistency and constancy. But environmental law is different from other legal disciplines, its nature inevitably oscillating between 
law and non-law (science, economy, politics, media), between knowability and impossibility to know, between more or less risk, between present and future generations. No doubt some of these idiosyncratic features can be encountered in other legal disciplines too. However, their accumulation brings about an intensification of uncertainty that renders environmental law a truly sui generis discipline. One of the characteristics of such a nature, therefore, is also environmental law's inherent marginalisation of the concept of the centre. Environmental law decentres the centre, responding to a newfangled and profoundly unsettling discovery: that whatever was thought to occupy the centre around which the environment was required to turn and twist has long departed, leaving behind a barren nostalgia. Hence environmental law's simultaneous all-encompassing presence and disciplinary emptiness.

The other reason for the change is the fragmentation of the environmental subject. The artificiality of the division between human and natural as imposed by natural disasters on the one hand and climate change, on the other, is rapidly losing ground. At the same time, the traditional insistence on subject/ object distinction has been dramatically banalised by such ecological radical thinking as Christopher Stone's proposition that trees should have standing. ${ }^{17}$ To link it with the previous comments about the etymology of the term 'environment', the separation between movement and stability is no longer impermeable. Environmental law has already observed the transgression between external movement and internal stasis, between environmental offering and human receiving. Again, this awareness is less ecologically driven than necessity-dictated. Regardless, the changes are already taking place and environmental law finds itself at a point of 'turning', of 'environing', as it were, of spinning around itself in order to locate its new role, its function. Perhaps the most advantageous (because of its anti-foundational effect) feature of environmental law over other legal disciplines is its unique position as a 'luxury' item that comes decidedly after survival, development, economic viability, etc., and simultaneously a matter of life or death in terms of nuclear catastrophes, climate change and rising sea level, environmental health, GMOs and so on. This superfluity and necessity seem to span precisely the scope of its action: environmental law is a law that, on the one hand, looks into itself, its legal construction and identity as a system that can be relied upon to produce consistent decisions; and, on the other, looks outside itself, desperately trying to accommodate concepts, operations, geographies and temporalities that have never hitherto been part of any legal description. Environmental law seems to be attempting to bridge the distance between the inside and the outside, stability and mobility, what is being surrounded and what is around.

'What is the line that separates the inside from the outside, the rumbling of the wheels from the scream of the wolves?'18 asks Italo Calvino, in full knowledge that the line is never anywhere to be found except on the other 
side, in a space of invisibility, absence, paradoxical coagulation. This is the space of opportunity as well as responsibility. Environmental law is a major potential tool for such an environmental revolution - because these changes suggest nothing less than that. The way environmental law operates within society (reversing, decentring, fragmenting) is already in itself an event of transgression - and one can only hope that this is not a short-lived moment, but one that will capitalise on its momentum and remain appropriately destabilising. But such an opportunity brings along a foundational responsibility. Not so much a responsibility for environmental action. That too, of course. But fundamentally, this is a responsibility for a radical theoretical reconfiguration of environmental law, one that will no longer rely on the old semantics of environment as resource, of the human as centre, of the logocentric idolisation of public participation, of illusionary discursive consensus, of causality proven and best means measured. Only a radical rethinking that will distance itself from the above and live up to the challenge of environmental degradation will bring the kind of environmental action that is required, targeting the root rather than the symptom and assisting environmental law in its crystallisation as a truly radical legal discipline. This, I argue, is what Critical Environmental Law is about. I shall now approach a discussion on how to conceptualise a Critical Environmental Law through the theoretical tradition of autopoiesis.

\subsection{The autopoiesis of environmental law}

Autopoiesis means 'self-creation'. ${ }^{19}$ The process is complemented by an element of continuous self-generation. Autopoietic production is circular, and the product is autopoiesis itself. Thus, life is autopoietic in that its produce is further or more life. Although of biological beginnings, ${ }^{20}$ autopoiesis revolutionised the sociological theoretical arena by applying itself to social systems, such as law, economy, politics, religion, and so on. ${ }^{21}$ Saying that law is an autopoietic system manifests an indifference towards law's beginnings, with a consequent reluctance to engage in how, when or why law becomes law. Likewise, to designate environmental law as an autopoietic system embodies the urgent desire to deal with the present, the topology of 'here' and the responsibility that stems from such dealing. Indeed, in autopoiesis, the most relevant moment is the present. All systems operate in the present. The past is included in the form of memory while the future in the form of expectations, both of which are exclusively present operations. At the same time, the specific temporal focus dictates a spatial focus. The topology of autopoiesis is a grounded, geographically expanded, material and corporeal presence, with a strong sense of the uncertainty, multiplicity of directions and disorientation that are brought in with the spatial discourse. ${ }^{22}$

In that sense there is no 'historical' foundation in autopoiesis, no centrality from which everything originates, no necessary precondition (such as the 
human in the centre) for the existence of the system. But if there were one, that would be the paradox. The autopoietic paradox is the distinction between system and its outside. This outside in autopoiesis is called environment, and enables the system to define itself in contradistinction. So, at least prima facie, the environment is whatever is not system. The autopoietic system remains closed to its environment, in that the latter is a terra incognita for the system, a space outside the limits of the self, the nest of a radical, sometimes threatening sometimes simply indifferent otherness. The interesting double entendre of the term should not go amiss. Just as environmental law deals with an indefinable, rather vague and certainly uncontrollable (natural) environment, in the same way an autopoietic system deals with an (autopoietic) environment that is neither known nor knowable to the system.

The parallels are deeper than just terminological. Just as environmental law's foundational paradox of all-yet-nothing informs both the way the discipline is developed and the kind of theoretical elaboration pursued here, in the same way an autopoietic system both is and is not a system. It has nothing focal, central or fixed about it and its environment does not 'turn' around it. It is unfortunate that the term 'system' gives the impression of systematicity, of normative promise and unfailing consistency, of a method, itself systematic, that produces systematised units of formed boundaries. But an autopoietic system is nothing of the sort. ${ }^{23}$ If, faithful to its etymology, the term denotes a syn ('together') and histanai ('to set up', 'to stand'), a togetherness that has been set up (is this setting up arbitrary? and who has set it up? itself? without discernible origin?), an assemblage of sorts without promise of future form, consistent boundaries, identifiable characteristics or positive functions; if a system is a machine in the Deleuze-Guattari sense that is nothing but connections and operations in a constant process of what they call deterritorialisation, namely the becoming other than itself, always at another stage which engulfs and is engulfed by its otherness: ${ }^{24}$ if a system is all that, that is, if a system is not, then an autopoietic system is indeed a system. Conversely, if as Derrida points out, 'by "system" is meant ... a sort of consequence, coherence and insistence', ${ }^{25}$ namely a continuation provided by a responsibility to a fractal lucidity that always returns, then, again, an autopoietic system is a system.

An autopoietic system, therefore, is an unpremeditated thrown-together of events which become 'solid' and relatively permanent through repetition. It is a snapshot of an eventful moment with a specific topology and limits, which, however, are bound to change at the next snapshot opportunity. Like an amoeba, a system spreads and contracts, every time including more or less of its environment (and thus converting it into system) depending on the situation. This is precisely how environmental law is to be conceptualised. There is nothing central, focal or fixed in the concept and practice of environmental law. Rather, every act, process, piece of legislation or decision is disrupted by the law's environment, namely the conditions under which these 
are formed and the impossibility of knowing precisely those conditions. The environment, both for autopoiesis and environmental law remains uncharted and unknowable. Yet, or because of that, it embodies the object of desire for the system, the tender protégé of environmental law which simultaneously is the exploited field of cognitive and material expeditions for more raw matter, more energy, more technology, more information. The environment brings together (without ever managing to reconcile convincingly) the desire to possess and the desire to protect against possession.

It is obvious from the above that the definitional ambiguity of the concept of the environment can be explored in a parallel mode within both the ecological and the autopoietic discourse. This is consolidated by the impossibility of finding an exact location for the environment (in its double meaning) in relation to the system (namely environmental law). Although the environment is the system's material object of 'study', it remains outside the system. Although it remains outside the system, it helps define what a system is from within the system. This can only be expressed in a paradox: the environment nests both inside and outside the system, in a demonic bilocality that irritates the system without declaring its topology, and contributes to the autopoietic construction by planting an excess of uncertainty, complexity and angst within the system. The irreducible ecological complexity establishes in the system an increasing amount of uncertainty. What is more, it is an uncertainty that does not have a traceable origin. If the environment remains unknowable to the system, anything that comes from the environment appears as a symptom of the system itself without traceable external source. This recalls autopoiesis's biological roots: on the level of cells, any irritation from outside is perceived as internal symptom. In the same vein, fever is the symptom through which we perceive that an organism is reacting to an external virus. The same construction applies to environmental law: the object of environmental law is its environment. Of course, the environment is replicated inside the law, cut down in legal chunks that can be swallowed by the system, reduced to a resource. Environmental law does the best it can in order to manage, to control its environment. But even then, in the fissures between the impossibility of fixing societal expectations, the ever changing nature of the data involved, the ethical connotations of any present decision, the future effects and the urgency of such decisions: even then, environmental law is not immune to the effects of the uncontrolled uncertainty that rushes in, a legal angst that no chopping up of the environment in bite-size legal information can ever assuage.

It is obvious that such an insistent need for constant balancing cannot produce fixity. On the contrary, 'insistence leads to difference; that is, to the impossibility of identification and totalization' ${ }^{26}$ It produces the difference between the system's continuous attempt to describe itself and a continuous interruption by its environment which establishes a permanent $d y$ sfunction in the system: "this dysfunction not only interrupts the system but itself 
accounts for the desire of the system, which draws its élan from this very disadjointment, or disjunction'. ${ }^{27}$ The system clings onto its environment with a longing whose object is precisely the maintenance of this difference, and renders this disjunction its beloved symptom. Indeed, this is the desire of the system: to maintain its impossibility of ever becoming a 'system' (and on the other extreme of desire, for ever to become its environment). In this respect, the environment of the system is the system's self-'deconstruction'. As Luhmann admits, 'something always has to be left unsaid, thereby providing a position from which to deconstruct what has been said'. ${ }^{28}$ The unsaid is folded in the other side of the garrulous system, and at the same time within the system itself.

\subsection{Four critical autopoietic positions}

Having explained albeit too briefly the autopoietic paradox and how it can without a conceptual leap be applied to environmental law, I would now like to present four basic positions of autopoietic theory that can inform the present conceptualisation of environmental law. These positions further elaborate the 'catching up' necessities for environmental law as mentioned in the opening section of this chapter, essentially bringing environmental law up to date with some of the recent theoretical developments in humanities. This I opt to do through the theory of autopoiesis, or at least my reading of it, which is influenced by poststructuralism and post-ecologism. This reading does differ from autopoiesis the way Niklas Luhmann has sketched it by placing a differentiated focus on specific issues and processes. It is therefore best to talk about a critical autopoiesis, which is better suited to deal with a Critical Environmental Law.

First, autopoiesis is acentric. It specifically decentres the centre by displacing its centrality to always another centre, itself debilitated by the rupturing continuum between system and environment. This can be put in two ways: on the one hand, the environment of the legal system consists of all other social systems such as politics, media, economy, science, and so on. While law sees an issue from its own legal perspective, the same issue is seen by other systems in their respective perspective. Thus, the opening of a nuclear power plant is as much a legal matter as it is an economic, political, mediarelated matter. If the law looks into EIA and planning issues, economy will look into national and regional effects, politics will look into local opposition and national interest, and so on. However, no one perspective is central, since all complement each other. There is no überperspective that can deliver the final judgement. Even if economics seems to be the flavour of the day, it is still not able to decide unilaterally. ${ }^{29}$ The other way in which the autopoietic acentricity can be put is from the point of distinction between system and environment. A system can be the centre of autopoiesis because it includes within its boundaries its environment. This is the only way in which 
the system can address the challenges of its environment, since otherwise it remains closed to it. The system reproduces a version of the environment but in a way that it fits in with the system's own understanding of possibilities. Still, in being internalised by the system, the environment dilutes the system from the inside, decentres it by demonstrating its own limits. The system realises its impossibility to act, becomes conscious of its own limitations.

Second, autopoiesis de-individualises the individual. This is arguably the greatest thorn of autopoietic theory. Social systems such as law, politics, etc., do not consist of human beings and their actions, but of anonymous, mechanical processes that lie beyond the control of humans. Luhmann's anti-humanist gesture that seemingly degrades the human to a cog in society's wheels is quickly revealed to be a gesture of acentric pluralising. Thus, the non-divided nature of the individual is mobilised under 'more complex and less restricting' conditions than those of systemic structure, based not on the liberal conception of the individual's abilities but on the freedom of 'irrational and immoral behaviour'. ${ }^{30}$ This seemingly odd reversal of freedom is nothing but an antidote to the rigidity of social systems. It follows that any positioning of agency that attempts to make a difference will have to take into account its prior projection on to the empty canvas of systemic operations. ${ }^{31}$ This is simultaneously more and less empowering than it sounds at first. It is more empowering in that it frees the individual from the limitations of systemic closure: only from such a position can the human factor be understood in its relation to systems as a possible instance of resistance against the system. It is less empowering in that it denudes agency from illusions of societal control: the structures that determine an individual's fate is both inside the individual (thus for example, capitalism can finally be moved firmly to the level of desire, as Lyotard has suggested ${ }^{32}$ ) and well beyond her control. This however complicates the frequent assertion of structures 'controlling' the lives of individuals and makes the process both ambidirectional and deprived of control: both guilt-free and guilt-ridden. Once this has been established, then one can talk about, say, agency, protest movements or revolt as a way that breaks into systems. But this will be already grounded on the de-individualising multiplicity of the human.

Third, autopoiesis begins and carries on with difference. A system is not a system but simply the arbitrary snapshot of an assemblage of processes at the specific present moment. The next moment, the system will have internalised a different chunk of its environment and will have expanded or contracted its topology accordingly. Any attempt at essentialising what is a system is destined to fail. Any beginning is arbitrary, any origin is constructed, any perspective is yet another, any boundary is fluctuating. On this shifting ground, autopoiesis relies on the difference that every time makes the difference: whether it is the always different boundary between system and environment, the always different understanding of an issue depending on the systemic perspective, or the always elusive nature of continuous self-generation which 
autopoiesis itself embodies, difference can never be reduced to an arbitrary unity; and when it is, such as when the legal system must take a decision that necessarily privileges one solution over the maintenance of difference, the other possibilities remain contingent, for ever haunting the system from the inside. ${ }^{33}$

Finally, autopoiesis discredits prescription. Luhmann keeps repeating that autopoiesis only describes and can never prescribe. This is because it does not have space for transcendence, for another utopian society, for a reality where things are better. Autopoietic reality is what there is and everything, from capitalism to communism to revolution to apathy, is inscribed in it. This may sound unduly claustrophobic, but it delivers from the illusions of easy solutions, facile impressions of control between systems, populist expectations for immediate change. Autopoiesis does not say that things do not change. It simply says that they take much longer than currently politics allows us to believe. Further, not only autopoiesis cannot instruct solutions of influence, intervention and control, but it significantly trivialises prescription. Autopoiesis remains conscious of the fact that it is just one description amongst many. A fundamental tenet of the theory is the return to the awareness of its contingency, of its temporal validity, of its finite innovative potential and eventually its ability of being combined with other perspectives. ${ }^{34}$ This insistence on returning to description means that any unfolding of the paradox - autopoiesis's most luscious object of desire - remains a description orchestrated according to the means of the system in which the paradox is unfolded.

To sum up, autopoiesis promotes a theoretical paradigm that is acentric, fragmented, non-human centred, against delusions of facile solutions, control or influence between systems, and always returning to a description of realistic dimensions coupled with an awareness that it is only one theory amongst others. This epistemological humility encourages the constant reassertion of difference rather than unity and identity, and its continuous reconfiguration in the face of environmental changes. In what follows, I attempt to 'translate' these in the language of environmental law, thus describing the way I see environmental law's evolving in the face of a fundamentally uncertain and unknowable environmental reality.

\subsection{Four critical environmental positions}

An autopoietic description of environmental law builds precisely on the ability of the theory to accommodate uncertainty. While this is readily accommodated by mainstream environmental legal theory, it poses significant issues when the mechanics of uncertainty extend to the traditional bastions of legal unity, human agency, and perceived mission (rather than function) of the environmental legal system. Thus, the four critical autopoietic positions listed above are readily translated into what I call Critical 
Environmental Law: first, the autopoietic decentring of the centre, with its consequent pluralist paradox of multiple thematising (non-)centres, is in perfect accord with environmental law's understanding as a multi-layered, global, fragmented discipline, characterised by links that follow the transboundary nature of pollution. The radical potential of an autopoietic description in this respect is the realisation that all these centres remain isolated within their constructed difference with their environment - in other words, from mere pluralism to a radical acentricity. Against the prevalent concept of environmental interlinkages on the level of agents and actions, an autopoietic description of environmental law throws into relief the closure and consequently the miscommunication between the various centres by rendering their boundaries visible. The effect of an acentric autopoietic description is the abandonment of the paradigm of direct influence and intervention across differentiated ecological spheres, and its replacement with an indirect eavesdropping on the other side's mechanisms as part of the difference between system and environment. This can lead to either an enhancement of the applicability of the concept of ecological self-organisation, ${ }^{35}$ a more pluralist network application, ${ }^{36}$ or indeed a search for other ways in which even the concept of the environment as a whole should be formulated in order to capture the elusive centrality of ecological considerations.

Second, the autopoietic displacement of the individual as an undivided whole and its replacement with the difference between system and environment further contributes to the acentralisation of environmental thinking. It does so by relinquishing the dry dualism between anthropocentric and ecocentric legal protection and extending the blurring between the 'natural', the 'human' and the 'artificial' in line with biopolitical readings that point to precisely this kind of fragmentation and reinstitute a post-humanist form of continuum/rupture, referring variously to human/non-human nature, and to the way in which these differences are conceptualised. ${ }^{37}$ The beginning of this line of thought can be traced in deconstruction - thus Gayatri Spivak: 'identity [is] disengaged in terms of who was and who was not human. That's why all these projects, the justification of slavery, as well as the justification of Christianization, seemed to be alright; because, after all, these people had not graduated into humanhood, as it were.' 38 This has been transposed into ecological thinking, with a pioneering ecofeminism, especially through the writings of Val Plumwood and Catherine Merchant, ${ }^{39}$ whose ecocriticism of pre-existing binarisms has had a measurable effect on feminist theory as a whole. Thus, Donna Haraway has famously declared that 'the boundary between human and animal is thoroughly breached' and cyborgs, oncomice and coyotes are post-humanist dimensions of more traditional feminist bodies that transcend the natural/cultural, organic/mechanical, physical/nonphysical and so on divides. ${ }^{40}$ In a non-dissimilar vein, although from a different point of view, Bruno Latour talks about 'hybrid networks' between social, informational and ecological systems, ${ }^{41}$ and the 'pluriverse' consisting of 
collectivities of humans and non-humans that redefine democracy as something that can be found either side of the boundary. ${ }^{42}$ Likewise, Katherine Hayles's digital subjectivity is built on a discontinued and inherently unpredictable conception of the human, ${ }^{43}$ while, closer to autopoietic things, Gunther Teubner refers to the legal role of private actors, incidentally via the example of rats. ${ }^{44}$ From a different perspective, Giorgio Agamben locates the homo sacer, the bandit and the werewolf right there, on the threshold between continuum and rupture: "what had to remain in the collective unconscious as a monstrous hybrid of human and animal, divided between the forest and the city - the werewolf - is, therefore, in its origin the figure of the man who has been banned from the city ... a threshold of indistinction and of passage ... who dwells paradoxically within both while belonging to neither' ${ }^{45}$ It is obvious that, in view of all this, Luhmann's relegation of the human outside the system opens up an avenue of differentiated but unprioritised inclusion of the 'natural' ('artificial', 'human', and so on), the systemic reference to which empties out a space of absence within the system that accommodates precisely the impossibility of ever comprehending the environment.

Third, an autopoietic description can begin only with difference. The initial problem may be that unity (ecosystemic, ecological, and so on) is a staple starting point of the ecological discourse, in combination with a unifying centre and a homeostatic goal. ${ }^{46}$ Autopoietic difference ruptures this continuum, both in terms of communication and temporalisation, and renders any perspective (the ecological included) simply yet another perspective. The awareness of 'just another perspective' is a deep trauma to ecological thinking which describes itself as the only available unity that can make a difference in the face of urgent environmental issues. Assuming one unitary überperspective and messianically inviting society to follow, is something that Luhmann could not easily accept, despite his arguably sympathetic position to the ecological cause. ${ }^{47}$ Luhmann's description includes the environmental perspective but in a status always parallel to that of other positions, such as the economic, the political and the scientific. This does not preclude prioritising one over others but entails a continuous awareness of other perspectives and their way of internalisation of the ecological problem. The radical contribution of autopoiesis to the environmental issue is the continuous deferment of origin to further instances of difference, rather to a unitary illusion of ecological harmony, often expressed in the form of community nostalgia. ${ }^{48}$ At the same time, autopoiesis presents a system - in this case, the environmental legal system - with an awareness of illusion of any identity the system may construct for itself. This means that uncertainty becomes a structural and constantly present inevitability rather than an invisibilised externality in view of the illusion of identity.

Fourth, the autopoietic preference for description over prescription is yet another indication of the awareness of limits and limitations of the various systems. The overly prescriptive nature of environmental discourse, even in 
its legal theoretical aspect, urges towards a rushed search for short-term solutions that misunderstands the capacities of the various systems involved in the complexity of ecological protection. While environmental problems are not discounted either by Luhmann, ${ }^{49}$ or indeed by this text, they are contextualised within and through an acentric system (be this law, politics, science, economy). In this sense, environmental problems are contextualised but not relativised: each systemic description is compromised only by the realisation of its own limitations that emerge in the system. In other words, any prescription can only work from within the system, in full respect of (and therefore, doubt, resistance, revolt against) the system's limitations.

And this is where critique should be located. In the instant version of Critical Environmental Law, critique is always from the inside, balancing on the paradox between distance from and propinquity to the object of critique. What is the object of critique of a Critical Environmental Law? And who is to exert it in an acentric, non-human, almost non-systemic environmental law? The two are interchangeable: the same processes that apply themselves to a supposedly balanced protection of the environment, in the acentric, cross-checking, non-definitive manner of autopoiesis, are the ones who both criticise and are criticised. Critique can turn only towards itself, in a veritably autopoietic twist, and criticise itself. Critical Environmental Law is a branch of law that keeps on doubting its given nature as law - for what is law? And how can law comprehend the tidal waves of environmental uncertainty that push the system from all sides? Further, Critical Environmental Law keeps doubting its conceptualisation of the environment. What is the natural? How to differentiate between that and everything else? Indeed, why differentiate? Who decides what is worth protecting? How much environmental ethics can reasonably be internalised by the environmental legal system without the latter losing its 'legal' affiliation? The above questions could not of course be attempted within the ambit of the present text. But the seeds of doubt and critique can be planted. The concept and practice of an environmental legal responsibility are embodied precisely in the need to find an adequate theoretical approach (and arguably not one but several, even contrasting and incompatible) that will adequately address the environmental uncertainty with which environmental law is required to deal.

The above perfunctory application of autopoiesis to environmental law and ecological thinking at large seems to have the paradoxical effect of 'dispersing' and 'diluting' environmental values while reasserting systemic limits and limitations. Although they may initially seem contrary to some of the basic tenets of current ecological thought, ${ }^{50}$ they represent a way for a potentially more efficient environmental protection which relies on societal internalisation of the environment in a way that simultaneously 'debilitates' the notion of environment and reinforces the awareness of systemic limitations such as law, politics or economy. Let me, therefore, sum up epigrammatically the reasons for which an autopoietic approach to environmental law 
is justified: first, autopoiesis is an adequately complex theory to describe the complexity of a newly emerging yet highly technical legal discipline; second, autopoiesis conceptualises systems in a grounded way that, while describing potentialities, marks systemic limitations. This is particularly relevant to a system, like environmental law, whose object is constantly redefined in ways in which the system has no control over. Third, the autopoietic mistrust towards prescriptions that encourage control and intervention is particularly apposite to an otherwise aggressively abused branch of the legal system, whose services are variously internalised in order to fit in with more pronounced priorities, such as economics or politics. This does not mean that autopoiesis can change the way legal reality is, but merely the way it is understood and contextualised. And finally, by plunging in and out of the particularity of systemic perspectives, autopoietic abstraction enables the interdisciplinarity that is needed for any adequate description of environmental law.

\section{Notes}

1 Tarlock, 2004: 217.

2 Beck, 1999.

3 Philippopoulos-Mihalopoulos, 1999.

4 See Pottage, in this volume.

5 There are several texts that deal with the issue, some (e.g., Delaney, 2003; Teubner et al., 1994; Gillespie, 2002; Halsey, 2006; Holder and McGillivray, 2001; Stallworthy, 2008) more successfully than others. Still, they do not amount to a critical mass, namely a mass that can confidently question itself.

6 Smith, 1994: 1079; see also Richardson and Wood, 2006.

7 The concept originates in international law - another discipline which, even at this stage, is failing to fix expectations normatively. According to Teubner, 1996, lex mercatoria is another form of soft law, hence his and his contributors' efforts to amplify its autopoietic ambit.

8 Flournoy, 1994.

9 See Carolan, 2008.

10 Tarlock, 2004: 220.

11 Murphy, 1997: 161.

12 Farber, 1994: 791.

13 Luhmann, 2004.

14 Originally, the word 'environmentalism' was meant to contribute to the nature v. nurture debate. See http://www.etymonline.com.

15 Serres, 1995, for an account of the trial from an environmental point of view.

16 Holder and McGillivray, 2001.

17 Stone, 1974.

18 Calvino, 1993: 33, my translation.

19 From the Greek words auto, which means 'self', and poiesis, which means 'creation'. The term was coined by Maturana and Varela, 1972.

20 Maturana and Varela, 1972.

21 Luhmann, 1995, 2004; Teubner, 1993.

22 This is a reading of autopoiesis rather than Niklas Luhmann's more traditional understanding. See Philippopoulos-Mihalopoulos, 2009. 
23 See also Schwanitz, 1995, for a comparison with Derrida.

24 Deleuze and Guattari, 1987.

25 Derrida and Ferraris, 2001: 3.

26 Derrida and Ferraris, 2001: 4.

27 Derrida and Ferraris, 2001: 4.

28 Luhmann, 1993: 769.

29 An epiphenomenon of this acentrity is the theory's polycontexturality, namely the pluralist multiplication of function centres whose centrality is consistently displaced through parallel interweaving of isolated contextures, first by their context, namely their environment, and second (which is simply another level of the first) by other 'centres'. See Günther, 1973.

30 Luhmann, 1995: 212.

31 See Paterson, 1996.

32 Lyotard, 1993.

33 This is what I have called the waste of the system, which, just like material waste, becomes accumulated and obstructs society with its expanding uselessness, in the same way autopoietic waste remains within the system as the memory of forgetting. See my Absent Environments, 2007.

34 An example of this is the autopoietic flirtation with deconstruction, regularly appearing in the folds of Luhmann's texts, and frequently pointed out and explored by commentators: Teubner, 2001, 2009; Fuchs, 2001; Stäheli, 2000; Moeller, 2006; Philippopoulos-Mihalopoulos, 2009; to some extent, Ladeur, 1995.

35 Teubner et al., 1994.

36 Ladeur, 1994.

37 See Foucault's, 2003, monsters, and indicatively see further Ruddick, 2004; Sharpe, 2007; Braidotti, 2006.

38 Spivak, 1991: 229.

39 Plumwood, 1993; Merchant, 1980.

40 Haraway, 2004: 32.

41 Latour, 1993; for a contextualisation of hybridity see Grabham, 2006.

42 Latour, 2004.

43 Hayles, 2005.

44 Teubner, 2006; see also Baxi, 2007, especially $197 \mathrm{ff}$., for rights and the posthuman.

45 Agamben, 1998: 105.

46 To a large extent influenced by open systems theory, e.g., Odum, 1971; see also Blühdorn, 2000.

47 Luhmann, 1989.

48 See my dealings with ecological community in 2007: chapter 5.

49 As King and Thornhill, 2003: 194, note, the motivation behind Luhmann's ecological engagement can be said to have been 'a sincere and deeply felt concern for the predicament of the planet and the future of humankind'.

50 The implications of the connection are explicitly demonstrated in Blühdorn, 2000.

\section{Bibliography}

Agamben, G., Homo Sacer: Sovereign Power and Bare Life, trans. D. Heller-Roazen, Stanford CA: Stanford University Press, 1998.

Baxi, U., Human Rights in a Posthuman World: Critical Essays, Oxford: Oxford University Press, 2007.

Beck, U., World Risk Society, Cambridge: Polity Press, 1999.

Blühdorn, I., Post-ecologist Politics, London: Routledge, 2000. 
Braidotti, R., Transpositions: on Nomadic Ethics, Cambridge: Polity Press, 2006.

Calvino, I., Le città invisibili, Milan: Mondadori, 1993.

Carolan, M., 'The bright- and blind-spots of science: why objective knowledge is not enough to resolve environmental controversies', 34 Critical Sociology 5, 725-40, 2008.

Delaney, D., Law and Nature, Cambridge: Cambridge University Press, 2003.

Deleuze, G. and Guattari, F., A Thousand Plateaus, trans. B. Massumi, London: Athlone Press, 1987.

Derrida, J., and Ferraris, M., A Taste for the Secret, trans. G. Donis, ed. G. Donis and D. Webb, Cambridge: Polity Press, 2001.

Farber, D., 'Environmental protection as a learning experience', 27 Loyola of Los Angeles Law Review 3, 791-808, 1994.

Flournoy, A., 'Coping with complexity', 27 Loyola of Los Angeles Law Review 3, 809-24, 1994.

Foucault, M., Abnormal: Lectures at the Collège de France, 1974-1975, London: Verso, 2003.

Fuchs, P., Die Metapher des Systems, Weilerswist: Velbrück, 2001.

Gillespie, A., International Environmental Law and Ethics, Oxford: Oxford University Press, 2002.

Grabham, E., 'Taxonomies of inequality: lawyers, maps and the challenge of hybridity', 15 Social and Legal Studies 1, 5-23, 2006.

Günther, G., 'Life as polycontexturality', at http://www.vordenker.de, 1973.

Halsey, M., Deleuze and Environmental Damage: Violence of the Text, Aldershot: Ashgate, 2006.

Haraway, D., The Haraway Reader, London: Routledge, 2004.

Hayles, K., My Mother was a Computer: Digital Subjects and Literary Texts, Chicago: Chicago University Press, 2005.

Holder, J. and McGillivray, D., 'Locating EC Environmental Law', 20 Yearbook of European Law, 139-71, 2001.

King, M., and Thornhill, C., Niklas Luhmann's Theory of Politics and Law, Basingstoke: Palgrave Macmillan, 2003.

Ladeur, K-H., 'Coping with uncertainty: ecological risks and the proceduralization of environmental law', in G. Teubner et al. (eds), Environmental Law and Ecological Responsibility: The Concept and Practice of Ecological Self-organization, Chichester: Wiley, 1994.

Ladeur, K-H., Postmodern Constitutional Theory: A Prospect for the Self-organizing Society, 95/6 EUI Working Paper, Florence: European University Institute, 1995.

Latour, B., We have Never been Modern, trans. C. Porter, Cambridge MA: Harvard University Press, 1993.

Latour, B., Politics of Nature, Cambridge MA: Harvard University Press, 2004.

Luhmann, N., Ecological Communication, trans. J. Bednarz, Jr, Cambridge: Polity Press, 1989.

Luhmann, N., 'Deconstruction as second-order observing', New Literary History 24, 763-82, 1993.

Luhmann, N., Social Systems, trans. J. Bednarz, Jr, Stanford CA: Stanford University Press, 1995.

Luhmann, N., Law as a Social System, trans. K. Ziegert, ed. F. Kastner, R. Nobles, D. Schiff and R. Ziegert, Oxford: Oxford University Press, 2004. 
Lyotard, J. F., Libidinal Economy, trans. I. Grant, Bloomington IN: Indiana University Press, 1993.

Maturana, H. and Varela, F., Autopoiesis and Cognition: the Realization of the Living, Dordrecht: Reidel, 1972.

Merchant, C., The Death of Nature: Women, Ecology and the Scientific Revolution, London: Wildwood House, 1980.

Moeller, H. G., Luhmann Explained: From Souls to Systems, Chicago: Open Court, 2006.

Murphy, W. T., The Oldest Social Science? Configurations of Law and Modernity, Oxford: Clarendon Press, 1997.

Odum, H., Environment, Power, and Society, New York: Wiley, 1971.

Paterson, J., 'Who is Zenon Bankowski talking to? The person in the sight of autopoiesis', in D. Nelken (ed.), Law as Communication, Aldershot: Dartmouth, 1996.

Philippopoulos-Mihalopoulos, A., 'The silence of the sirens: environmental risk and the precautionary principle', 10 Law and Critique 2, 175-97, 1999.

Philippopoulos-Mihalopoulos, A., Absent Environments: Theorising Environmental Law and the City, London: Routledge, 2007.

Philippopoulos-Mihalopoulos, A., Niklas Luhmann: Law, Justice, Society, London: Routledge, 2009.

Plumwood, V., Feminism and the Mastery of Nature, London: Routledge, 1993.

Richardson, B., and Wood, S. (eds), Reader on Environmental Law for Sustainability, Oxford: Hart, 2006.

Ruddick, S., 'Domesticating monsters: cartographies of difference and the emancipatory city' in L. Lees (ed.), The Emancipatory City, London: Sage, 2004.

Schwanitz, D., 'Systems theory according to Niklas Luhmann: its environment and conceptual strategies', 30 Cultural Critique 1, 137-70, 1995.

Serres, M., The Natural Contract, trans. E. MacArthur and W. Paulson, Ann Arbor MI: University of Michigan Press, 1995.

Sharpe, A., 'Structured like a monster: understanding human difference through a legal category', 18 Law and Critique 2, 207-28, 2007.

Smith, T., 'Environmental law: old ways and new directions', 27 Loyola of Los Angeles Law Review, 1077-92, 1994.

Spivak, G., 'Remembering the limits: difference, identity, and practice', in P. Osborne (ed.), Socialism and the Limits of Liberalism, London: Verso, 1991.

Stäheli, U., Sinnzusammenbruche. Eine dekonstruktive Lekture von Niklas Luhmanns Systemtheorie, Weilerswist: Velbrück, 2000.

Stallworthy, M., Understanding Environmental Law, London: Sweet \& Maxwell, 2008.

Stone, C., Should Trees have Standing? Toward Legal Rights for Natural Objects, Los Altos CA: Kaufmann, 1974.

Tarlock, D., 'Is there a there in environmental law?', 19 Journal of Land Use 2, 213-54, 2004.

Teubner, G., Law as an Autopoietic System, trans. A. Bankowska and R. Adler, Oxford: Blackwell, 1993.

Teubner, G., Farmer, L. and Murphy, D. (eds), Environmental Law and Ecological Responsibility: The Concept and Practice of Ecological Self-organization, Chichester: Wiley, 1994.

Teubner, G. (ed.), Global Law without a State, Aldershot: Ashgate, 1996. 
Teubner, G., 'Economics of gift - positivity of justice: the mutual paranoia of Jacques Derrida and Niklas Luhmann', 18 Theory, Culture and Society 1, 29-47, 2001.

Teubner, G., 'Rights of non-humans? Electronic agents and animals as new actors in politics and law', 33 Journal of Law and Society 4, 497-521, 2006.

Teubner, G., 'Self-subversive justice: contingency or transcendence formula of law?', Modern Law Review 72, 1-23, 2009. 


\section{Foucauldian-inspired discourse analysis}

\section{A contribution to critical environmental law scholarship?}

\section{Bettina Lange}

\section{I What is critical environmental law scholarship?}

This chapter ${ }^{1}$ suggests that Foucauldian-inspired discourse analysis - a theoretical framework and set of empirical research techniques - can further develop critical environmental law scholarship. ${ }^{2}$ Critical environmental law scholarship is not a unified, hegemonic project. It is informed by and contributes to the development of various theory fragments, drawing, for instance, on Marxism, feminism ${ }^{3}$ and post-colonialism. ${ }^{4}$ It does not seek to build one grand overarching social or legal theory.

If one were to categorise the research that has contributed to the development of critical environmental law scholarship, two main strands stand out. First, critical environmental law scholarship has built on the critical legal studies (CLS) tradition ${ }^{5}$ that provides external critiques of the foundations of liberal legal theory and thus some of the key instrumentalist and ideological claims of environmental law. ${ }^{6}$ For instance, from a Marxist CLS perspective it is questionable whether the main purpose of environmental law is to protect the natural environment, or whether its key function is to legitimise capitalist relations of production based on the exploitation of nature by reining in the pollution side effects of unsustainable economic growth. CLS also provides a critical gloss on the nature of environmental law. It critiques its reification, i.e. the idea that existing environmental legal relationships are inevitable, natural, material, and pre-given rather than socially constructed. ${ }^{7}$ Moreover, CLS suggests that environmental law cannot be conceived of as a coherent, stable and principled body of law that consists of determinate, clear and specific legal obligations. For every legal principle a counter-principle can be found. For instance, while the polluter pays principle suggests that the costs of damaging environmental impacts should be borne by those who cause them, the precautionary principle may require that state subsidies are paid to polluting companies in order to prevent environmental impacts. These contradictions within legal doctrine are considered to flow from the fundamental tensions at the heart of liberal political theory: citizens' freedom is both facilitated but also threatened by their relations with other citizens. ${ }^{8}$ 
Hence, a CLS perspective that searches for alternative, egalitarian ${ }^{9}$ visions of democratic governance can inform critical environmental law accounts that highlight the distributional impacts of pollution and the legal rules that seek to control it as well as the social justice aspirations of sustainable development. ${ }^{10}$

Second, critical environmental law scholarship has also built on socio-legal studies. They provide internal critiques that question in detail law's own specific and partial constructions of the social world on the basis of empirical data ${ }^{11}$ and social theory. ${ }^{12}$ Socio-legal studies thus question the gap between 'the rhetoric' and 'reality' of environmental law while often taking legal concepts and doctrine as the starting point for their research. ${ }^{13}$ Hence, socio-legal analysis has highlighted that not just the formal legal rules, but also the micro-dynamics of interactions between various actors in environmental law, such as regulators and regulated as well as citizens shape the meaning and consequences of environmental law obligations. ${ }^{14}$

While some critical legal scholars have criticised socio-legal studies for borrowing concepts from other disciplines, for instance through the 'law and psychology', 'law and economics' or 'law and anthropology' approaches, ${ }^{15}$ this interdisciplinary orientation of socio-legal studies ${ }^{16}$ is particularly relevant for further developing critical environmental law scholarship. Various neighbouring social science disciplines can help to analyse the specific contexts in which law, including environmental law, operates, such as the mind, markets and community. The contexts can act as constraints but also facilitators of environmental legal regulation. Hence, the interdisciplinary orientation of socio-legal studies enables to perceive limits to the instrumental use of law. It also helps to answer the question what type of environmental legal rules are most appropriate for addressing specific environmental problems. For instance, transaction cost analysis can inform choices - with reference to the criterion of allocative efficiency - between different legal concepts, such as negligence or strict liability torts, statutory environmental standards or trading schemes - that all seek to internalise the costs imposed by the negative externality of pollution. Hence, socio-legal studies add another layer of critical analysis that draws on social science techniques in order to question how environmental law constructs and sometimes regulates the social world. They therefore complement CLS which focuses on the poverty of liberal legal theory as the main ideological lens through which to conceive of social relations in the modern polity, including its environmental law.

But critical environmental law scholarship can be defined not just through reference to the two strands of legal critique that have contributed to its development, critical and socio-legal studies. It can also be defined through reference to a core set of questions that it seeks to address. First, it inquires into how environmental law stabilises or disrupts existing social orders. For instance, critical environmental law scholarship asks what systems of production and consumption are maintained or challenged through environmental law rules. How does environmental law contribute to the exercise of power in 
contemporary society? Who benefits and loses from environmental law's allocation of private rights and liabilities, public powers and duties? Critical environmental law scholarship thus can also contribute to debates about new modes of governance. ${ }^{17}$

Asking questions about the relationship between environmental law and social order can also involve rethinking key building blocks of social theoretical analysis, such as space and time. For instance, critical environmental law scholarship has drawn on legal geography in order to understand how environmental 'regulatory space'18 and geographical space transform each other. ${ }^{19}$ New insights into the acceleration and extension of social orders over time and space are provided by accounts of international environmental law. ${ }^{20}$ For instance, carbon trading regimes extend social relations over space by setting up economic exchange relationships that span different parts of the developed and developing world. But this expansion of social relations over greater distances through globalising environmental law, and its fostering of 'interconnectedness' on a global scale, are balanced by advocacy of 'localism' through environmental law. An example of the latter are arguments for the management of local natural resources by citizens who live close to them, for example through 'river basin democracy', and nuisance actions, i.e. rights of litigation for neighbouring landowners in cases of environmental damage. ${ }^{21}$

A second core question addressed by critical environmental law scholarship is whether key tenets of liberal legal theory provide valid assumptions for understanding environmental law. A belief in the autonomy of law, in particular the separation of law from a political sphere, and a belief that environmental justice flows from adherence to the rule of law, are questioned. Hence, critical environmental law scholarship develops a contextual understanding which traces intersections between politics, economics and the law. ${ }^{22}$ It also draws attention to the ambiguous role of private property in environmental protection. While the protection of private property rights underpins nuisance actions and emissions trading which have made an important contribution to environmental protection, it is also a significant obstacle to the development of interventionist public law powers that restrict private property rights of corporations and individuals for the purposes of environmental regulation.

Thirdly, critical environmental law scholarship asks how existing social orders can be transformed in order to achieve more sustainable forms of living. It therefore highlights that the social orders which environmental law stabilises are not universal, objectively given, transhistorical or unalterable. Instead, by mobilising the sociological imagination both for analysis and critique, critical environmental law scholarship reminds us that existing social orders can be transformed. Some critical environmental law scholarship thus links to political thinking about green utopias. ${ }^{23}$ Having outlined key elements of critical environmental law scholarship the next section will 
explore the contribution of Foucault's ideas about power/knowledge and agency to this academic project.

\subsection{Foucault on power/knowledge and agency: a new framework for thinking about key analytical problems in environmental regulation?}

There is a small but growing environmental law literature that draws on Foucault's radical critique of modernist conceptions of human agency, law and power. ${ }^{24}$ This section argues that Foucault's ideas on power/knowledge and agency provide an innovative framework for thinking about two key analytical problems in environmental regulation. The first concerns difficulties in identifying who actually is an 'actor' in environmental regulation and whether postmodernist or modernist perspectives can best account for agency in environmental regulation. On the one hand, environmental law empowers social actors, for instance through the granting of formal legal rights and powers. But, on the other hand, it is often difficult to know who actually is an 'actor', given that economic and political structures in which environmental regulatory regimes are embedded can restrain agency. A modernist structure-agency dualism seems to be, for instance, appropriate to capture the activities of large corporations which appear to break with impunity environmental law standards, as in the case of the oil trading company Trafigura that dumped illegally toxic waste in the Ivory Coast and sought injunctions to stop media outlets, including the Guardian newspaper and the $\mathrm{BBC}$ from reporting on the matter. ${ }^{25} \mathrm{~A}$ modernist conception of agency pits environmental NGOs against corporations and governments that carry out environmentally damaging activities. ${ }^{26}$ Environmental legal actors are either powerful or powerless. Their agency is an innate quality of their existence as well as restrained or facilitated by economic, political and legal structures. But such a modernist understanding of agency seems increasingly limited for analysing agency in environmental regulation. Agency is often dispersed within a network of environmental actors rather than simply located inside of corporate, public or individual legal actors. Contemporary environmental regulation is often characterised as network governance with agency being hardly visible and becoming decentred. ${ }^{27}$

Foucault's work can capture some features of the changing nature of agency in environmental regulation. His work goes beyond phenomenological approaches to agency, that refer to social actors' ideas and motivations which then become translated into specific behaviour. From a Foucauldian perspective human consciousness and its interpretative processes are no longer core to an analysis of how social actors understand the social world and how they act within it. Organisational forms (i.e. a public body or corporation that become involved in environmental regulation) cannot illuminate or obscure who is an 'actor' in environmental regulation; rather, it is discourses 
that now become central sites for understanding agency. Defined as historically contingent fields of knowledge expressed in talk and text, discourses construct agency. ${ }^{28}$ They include 'frames and cognitive schemata'. ${ }^{29}$ Discourse is not determined by the characteristics of an objective, separate world. In the absence of a correspondence theory of truth, it is rules of discourse themselves that enable speakers to generate statements and objects of discourse. Hence, agency is no longer the expression of a creative, autonomous subject. ${ }^{30}$ It is neither pre-given, nor inherent in social actors. Discourses both enable agency and restrict what can be thought and said about a topic at a particular point in history. The construction of agency is one of the effects of the power of discourses as illustrated by the following example. ${ }^{31}$

It has been argued that information asymmetries can help to explain why regulated companies can exercise significant power in their relationship with environmental regulatory authorities. ${ }^{32}$ The regulated often know more than the regulator about the technical details of their operations. But by themselves information asymmetries cannot explain why some actors are more influential in shaping the formation and implementation of environmental regulation than others. It is only because engineering and environmental science discourses are dominant that information asymmetries can become influential, for instance in negotiations over conditions in site licences issued for industrial installations under the Directive on Integrated Pollution Prevention and Control (IPPC) (2008/1/EC). According to Article 12 (a) of the IPPC Directive, 'techniques', for the purposes of the 'best available techniques' standard, include not just the hardware of an installation but also its systems for managing the installation, such as staff training, management structures and maintenance routines. But in practice IPPC licences focus on conditions that regulate the technical aspects of the installation. ${ }^{33}$ The dominance of engineering and environmental science discourses among regulators and regulated is one reason for the limited exploration of how approaches to staff management may contribute to enhanced environmental performance of installations. For instance, greater participation in decision-making by employees may enhance perceived levels of responsibility for environmental protection and thus reduce accident rates. When engineering and environmental science discourses are dominant in framing interactions between regulated and regulators information asymmetries, i.e. the unequal distribution of technical knowledge about the regulated installation, will have a bearing on who can exercise what degree of agency during the negotiation of environmental obligations. ${ }^{34}$ Hence Foucauldian-inspired discourse analysis provides an opportunity to transcend essentialist conceptions of legal actors. Instead individuals are perceived as subjects who are constituted within discursive structures which can be subject to change. ${ }^{35}$

Moreover, Foucauldian-inspired discourse analysis can also address a second core analytical issue in environmental regulation, the ambiguous status of scientific knowledge in environmental regulation. This ambiguity 
flows from the association of scientific knowledge with potentially contradictory tendencies in environmental regulation. On the one hand, environmental law increasingly relies on scientific knowledge. Yet, on the other hand, citizens' trust in science is declining. ${ }^{36}$ Moreover, reliance on science in environmental legal decision-making is often considered to reflect unresolved contradictions between, on the one hand, a scientific, technocratic and, on the other hand, a democratic approach to environmental governance. ${ }^{37}$ But the sciencedemocracy dichotomy may be misleading and, in fact, different conceptions of public administration informed by varying visions of what constitutes a 'good' and 'just' constitutional order may be the source of tensions between different roles for science in environmental regulation. ${ }^{38}$

Foucault's ideas on power/knowledge provide a lens through which this ambiguous status of scientific knowledge in environmental legal decisionmaking can be understood. From a Foucauldian perspective, the status of scientific knowledge is ambiguous because scientific discourses are implicated in power relations. In fact for Foucault there is a dialectical relationship between power and knowledge because power plays a role in the production of knowledge, and power relations "produce the truths we live by'. ${ }^{39}$ A Foucauldian perspective therefore questions a reified conception of science which generates expectations of a clear role for scientific knowledge in environmental regulation. Instead it generates rich, detailed descriptions of the variety of different scientific discourses ${ }^{40}$ that are actually invoked in environmental legal decision-making, including the silences of scientific knowledge that arise from a lack of scientific certainty or simply lack of scientific knowledge in the regulation of environmental problems. From a Foucauldian perspective there is not one unified conception of scientific knowledge. Rather, different scientific knowledges produce different effects of power. For instance, abstract, applied and advocacy knowledge can be distinguished. Advocacy science such as scientific claims mobilised in support of particular lines of argument, produce different effects of power than undisputed scientific facts. ${ }^{41}$ Hence, Foucauldian-inspired discourse analysis seeks to understand the effects of power of discourses by uncovering the detailed practices, tactics and strategies of scientific knowledges. Discourses generate effects of power, for instance by stabilising and fixing particular systems of meaning and thus closing off alternative ways of thinking about or discussing a particular issue. ${ }^{42}$ Laclau and Mouffe who have further developed Foucault's ideas on power/knowledge suggest that hegemony is exercised by determining the identities of objects and social practices in specific ways. ${ }^{43}$ But the fixing of meaning is never complete because a social sphere in which relational meaning is established is always open. ${ }^{44}$ To summarise, Foucault's emphasis on discourse enables to think differently about agency and power/knowledge, which helps to address two core analytical problems in environmental regulation, how to account for decentred and obscured agency in increasingly networked forms of environmental 
governance and how to explain the ambiguous role of scientific knowledge in environmental regulation.

But in order to argue that Foucault's ideas about agency and power/ knowledge can address - from a critical perspective - key analytical problems in environmental regulation, it is also necessary to rebut concerns about his wide conception of discourse. Foucault's notion of discourse has been criticised as being too amorphous and therefore as difficult to operationalise for empirical research and as having limited explanatory power. This criticism can be addressed in two ways. First, in Foucault's work itself discourse is bounded and anchored into 'social reality' by being related to non-discursive practices, including institutions. Some commentators have detected a narrowing in Foucault's conception of discourse from his earlier archaeological analysis of madness, the clinic and scientific discourses, to his later genealogical work. ${ }^{45}$ In his genealogical accounts of power and the development of the power/knowledge concept in the 1970s, he perceives discourse as less self-contained and inquires into how discourses are shaped by non-discursive practices. ${ }^{46}$ For instance, non-discursive practices can structure the conditions for the production of statements, that are key elements of discourses. ${ }^{47}$ Moreover, the concept of discourse starts to take more concrete shape by being related to institutions. Institutions appear in Foucault's analysis as institutional sites from which discourses are enunciated. The rules for the formation of discourse vary according to the particular institutional sites from which discourses emanate. ${ }^{48}$ These institutional sites help to generate discourses because there is no longer a humanist subject that speaks or writes discourses. These institutional sites are understood in post-structuralist terms. Hence they are not fixed stable social structures, or 'unified subjects' 49 that fulfil specific functions or result from transhistorical forces, such as the state. Institutions - mediating the discursive exercise of power - also feature in Foucault's definition of governmentality:

the ensemble formed by institutions, procedures, analyses and reflections, calculations and tactics that allow the exercise of this very specific albeit very complex, power that has the population as its target, political economy as its major form of knowledge, and apparatuses of security as its technical instrument. ${ }^{50}$

(Emphasis added)

Second, recent perspectives on discourse developed in the context of political science research into governance and regulation seek to rein in an amorphous concept of discourse by further developing the idea that discourses are framed by institutions. This entails, however, being less true to Foucault's postmodernist vision of discourse. Schmidt and Radaelli's 'discursive institutionalism' ${ }^{51}$ reverts back to a linguistic understanding of discourse, defining it in terms of 'language, narrative or communicative action', 52 including 
ideational elements such as 'values' and 'policy ideas'. ${ }^{53}$ Their account renders an understanding of how discourse accomplishes social action more specific by tying it to the operation of institutional forces in social life. They paint a subtle picture of a dialectical relationship between institutions and discourses. They suggest that institutions shape the contents of discourse, what people talk about, but also the communicative processes through which discourse is mobilised, i.e. who can talk to whom, for instance during public policy-making. ${ }^{54}$ Institutions are defined widely, not just as organisational structures, but as including the rules that arise from specific cultures and that are path-dependent and interest-based, yet can be subject to change. ${ }^{55}$ Different political-institutional settings frame discourse differently. ${ }^{56}$ But discourses can also stabilise or transform institutional frameworks.

Their argument, however, seems a little unclear once one looks at the potential mediating role of ideas in this dialectical relationship between institutions and discourses. On the one hand, ideas seem to be part of discourses. They 'constitute policy narratives, discourses and frames of reference' which can help actors to redefine their interests and redirect their actions within institutions. ${ }^{57}$ But ideas also seem to take on a more free-floating, independent role because they are perceived as capable of 'redefining economic interests' and 'reconfiguring interest-based political coalitions' in their own right. ${ }^{58}$ To summarise, while it is possible to address criticisms that Foucault's conception of discourse is too wide, in particular by linking the operation of discourses to institutions, it is still necessary to address criticisms that Foucault's work can not account for the role of law in modernity, in order to make a case that his ideas contribute to the development of critical environmental law scholarship.

\subsection{Can Foucault's work provide a framework for understanding modern environmental law?}

It has been suggested that Foucault's work hardly accounts for the role of law in modernity. One of the most persuasive and recent rebuttals of this criticism by Golder and Fitzpatrick ${ }^{59}$ argues that those who criticise Foucault for neglecting the role of law in modernity have misunderstood his conception of law. ${ }^{60}$ This section builds on Golder's and Fitzpatrick's argument, though it is sceptical of their suggestion that Foucault's work can be interpreted as placing law at the centre of social bonds in the postmodern society. This section argues that Foucault's work provides for an understanding of law that is particularly suited to develop critical environmental law scholarship, through its emphasis on norms and its critique of instrumental law.

Foucault's analysis of law in modernity has been criticised in various ways. It has been suggested that Foucault associated state law wrongly mainly with what he calls the 'classical age' (1650-1800) and that his notion of law is too 
narrowly focused on repressive state law. He is also thought to have insufficiently theorised law in modernity, because his work, such as Discipline and Punish and the first volume of The History of Sexuality points to the declining significance of regulatory state law. ${ }^{61}$ From the eighteenth century onwards - according to Foucault - bio-power, exercised over whole populations, also with the aid of knowledge produced by the modern social sciences, takes over as the main form of regulation. It relies also on individualising and normalising disciplinary powers ${ }^{62}$ exercised mainly over the body ${ }^{63}$ Hence, at the very least, Foucault decentres law by turning it simply into one among a range of governance techniques. ${ }^{64}$

But this decentring of formal state law chimes with trends in contemporary environmental regulation where state law 'command and control' regulation is just one among a range of regulatory techniques, that increasingly involve private actors and non-law tools, such as environmental management standards and codes of conduct. More importantly, Foucault's concept of 'norms' provides new ideas about intersections between law and a social sphere, and constitutes a new angle for critiquing instrumental conceptions of law.

According to Golder and Fitzpatrick, Foucault's conception of law has two facets. It can, firstly, be determinate but, secondly, also responsive to its environments. ${ }^{65}$ From this perspective, law cannot be pinned down in a specific location but oscillates between a space of determinate meaning, on the one hand, and openness towards a range of other, including disciplinary, techniques of power, on the other hand. This further develops CLS's idea that law is radically indeterminate, and turns this into an empirical issue, rather than just a theoretical assumption. According to Foucault, state law can have many facets and being sometimes determinate is one of them.

Hence, Foucault suggests that in modernity law operates more and more as a norm and assumes regulatory functions that are exercised through administrative, bureaucratic apparatuses. François Ewald's interpretation of Foucault's work further pursues this line of argument. Ewald considers law and norms as interdependent. He suggests that normalisation also draws on legislative schemes, and law often formulates bureaucratic norms that 'qualify, measure, appraise and hierarchize'. ${ }^{66}$ This 'social law' ${ }^{67}$ no longer relies on abstract, universal principles. ${ }^{68}$ What is legal or illegal is defined with reference to notions of 'social normality', derived from the customs and habits of a given social group at a particular moment in time. ${ }^{69}$ Hence the law becomes a politicised instrument of government and plays a significant role in resolving conflicts about the allocation of resources and access to political decision-making. ${ }^{70}$ Norms are grounded in society itself, not in a 'fixed, transcendent' sphere of values. ${ }^{71}$ They ultimately reflect society's relationship with itself.

This understanding of 'norms' chimes well with contemporary environmental law, in which not just environmental principles matter. The bulk of statutory 
pollution control regimes for instance, is made up of technology norms that refer to a 'norm', such as 'the best available techniques' or 'best practice' environmental management standards. Ewald's interpretation of Foucault's ideas about law also provides a basis from which to critique the significant reliance on technology, management and scientific norms in environmental law. Their limitation in driving behavioural change flows from the theoretical assumption in Ewald's work, i.e. that they are socially embedded. They describe rather than prescribe behaviour in relation to environmental obligations.

Moreover, Golder's and Fitzpatrick's conception of Foucault's law as relational provides a new angle from which to criticise instrumental conceptions of law, a staple of socio-legal studies and a key element of critical environmental law scholarship. Golder and Fitzpatrick suggest that Foucault's law is not just a determinate and contained entity, but is also 'illimitable' and thus responsive to what lies outside current legal propositions. It is open to transformation. ${ }^{72}$ To recognise law as being open to a social sphere is a wellworn claim of socio-legal studies. But Foucault's perspective adds a twist because he understands a 'social sphere' in postmodernist terms as a 'space of dispersion'73 that opens society up to the possibility of alternative social formations. ${ }^{74}$ This is different from a modernist conception of a social sphere as bounded, stratified and structured. Foucault's account allows law to become an instrument of a range of powers, but through its responsive nature, including resistance to various forms of power, law is also always in flux and open to change, which prevents it from being deployed in a strategic and instrumental manner.

To summarise, the criticism that Foucault has insufficiently considered the role of law in modernity can be rebutted. In fact his work provides for an innovative conception of norms, law's openness to a social sphere and its limited instrumentality. Most importantly, his ideas point to the significance of empirical research for developing critical accounts of law. Hence the next section analyses administrative authorisation procedures for transgenic agricultural products in the European Union on the basis of Foucauldian-inspired discourse analysis.

\subsection{Analysing environmental authorisation procedures through the lens of Foucauldian-inspired discourse analysis}

There are many types of discourse analysis ${ }^{75}$ and many interpretations of Foucault's ideas and hence there is not just one specific meaning of 'Foucauldianinspired discourse analysis'. I use the term 'Foucauldian-inspired discourse analysis' in order to refer to a loose theoretical framework that is also associated with a set of empirical research techniques. It is therefore an approach rather than a specific methodology. Foucault himself did not intend to develop a unified grand social theory or a systematic methodology. ${ }^{76} \mathrm{He}$ 
sought to develop analytical accounts of the operation of power that are situated in particular local social practices.

One of the key features of Foucauldian in comparison to other types of discourse analysis is its anti-realist stance. It works with a performative understanding of language where linguistic expressions of discourse do not just represent the social world but actively construct it. Meaning arises from differences between terms, such as science and politics, and not as the result of any correlation between linguistic terms and objects located 'out there in a real social world', such as a political system or 'science'. ${ }^{77}$ Hence, Foucauldianinspired discourse analysis does not seek to explain discourse with reference to underlying social structures, such as material conditions, or power relations, that are considered to be obscured by discourse. In fact discourse analysis marginalises social structures in its analysis and even fragments the very idea of a social structure ${ }^{78}$ in line with poststructuralist fluid conceptions of social structures. ${ }^{79}$ But whether and how Foucauldian-inspired discourse analysis can contribute to the development of critical environmental law needs to be analysed also with reference to specific fields of environmental regulation. The next section therefore seeks to apply some of Foucault's ideas to an analysis of EU authorisation procedures for transgenic agricultural products.

\subsection{A critical account of EU authorisations for transgenic agricultural products: from democratic deficits to disciplining emotion discourses}

Foucauldian-inspired discourse analysis can help to identify an interesting research puzzle in relation to the administrative authorisation of transgenic agricultural products in the EU. So far critical accounts have focused on the political structures underpinning EU GMO authorisations and their glaring democratic deficit. ${ }^{80}$

According to Regulation 1829/2003/EC ${ }^{81}$ and Directive 2001/18/EC ${ }^{82}$ transgenic agricultural products, such as genetically modified (GM) seeds, plants as well as human food stuffs and animal feed, imported into the EU from third countries or produced within the EU, need to be authorised in order to be sold or legally released into the environment. Directive 2001/18/ EC and Regulation 1829/2003/EC provide administrative authorisation procedures for this purpose. Both pieces of EU legislation seek to protect human health and the environment, with Regulation 1829/2003/EC pursuing also the protection of animal health, consumer interests and the functioning of the internal market. Scientific discourses are key to the assessment of the risks posed by transgenic agricultural products in these authorisations. ${ }^{83} \mathrm{At}$ the heart of these scientific discourses are a risk assessment of the genetically modified organism carried out by the applicant biotech company which is evaluated in a separate report by a national competent authority under 
Directive 2001/18/EC or a safety assessment carried out by the European Food Safety Authority (EFSA) under Regulation 1829/2003/EC.

Both Regulation 1829/2003/EC and Directive 2001/18/EC distinguish between a first scientific phase of risk assessment and a second political phase concerned with risk management. Risk management decisions are taken by a Regulatory Comitology Committee. But in particular in relation to authorisations under Directive 2001/18/EC member states do not arrive within the required time-limit of three months at qualified majorities because they are split in their support for and opposition to transgenic agriculture. Moreover, some member states abstain from voting in response to national public opinion being opposed to GMO agriculture. If member states cannot achieve qualified majorities in the Regulatory Committee or the Council, the decision about the authorisation of a specific transgenic agricultural product reverts back to the Commission. ${ }^{84}$ Hence, the Commission becomes the final decision-maker in relation to its own proposal for the release of a transgenic agricultural product. In most of the so far authorised GMO products ${ }^{85}$ the Commission has put forward and decided upon its own proposals about the authorisation of transgenic agricultural products.

This democratic deficit is further compounded by the fact that provisions for public participation at the EU level in GMO authorisations are weak. The legally non-binding preamble 46 to Directive 2001/18/EC suggests that EU citizens' comments should be taken into account when the Commission proposes a draft decision on the GMO application to the Regulatory Committee. Regulation 1829/2003/EC does not spell out how EU citizens' comments, for instance on EFSA's scientific opinion should be taken into account in Commission draft decisions. Article 7 (1) of the Regulation enables the Commission to consider 'any other legitimate factors relevant to the matter under consideration' and this may well include EU citizens' comments. But the Regulation does not impose a duty upon the Commission to consider EU citizens' comments when making its draft decision.

These legitimacy problems become apparent through a macro-level analysis of the formal EU legal framework and the political dynamics underpinning EU GMO authorisations. But an examination of EU GMO authorisations on a micro-level through a Foucauldian lens opens up a different perspective and enables to trace more subtle democratic deficits. They involve privileging some and marginalising other discourses that frame arguments for and against the authorisation of transgenic agricultural products. In particular emotion discourses based on trust that affirm science-based legal regulation are privileged, while emotion discourses that mobilise fear about the impacts of transgenic agricultural products as well as emotion discourses that appeal to empathy with those who may benefit from transgenic agriculture are sidelined. These emotion discourses matter, even though scientific discourses about the risks posed by transgenic agricultural products to human health and the environment that rely on experimental data derived from field trials and lab 
tests on animals, are at the heart of EU GMO authorisations. From a descriptive perspective, emotion discourses can be defined as talk and text and thereby knowledge - generated as part of submissions in EU GMO authorisations - that draws on emotion terms. Hence, emotions are analysed as the topics and concerns of talk, not as its causes. ${ }^{86}$

For instance, EU citizens' comments on EFSA scientific opinions contain the following emotion terms: 'Frankenstein foods', 'superweeds' and 'superpests' as well as 'suicide seeds' in order to refer to sterile GM seeds. ${ }^{87}$ These emotion terms express strong evaluations of GMO products and their legal regulation. They constitute a break in register with non-emotionalised arguments such as descriptive statements that focus on 'factual information'. From a functional perspective, emotion discourses involve arguments that express or seek to generate an emotional response in other participants in authorisations, such as anger, fear, empathy or trust. They may rely on emotion terms, but do not have to. For instance, some arguments seek to generate fear about the potential health or environmental impacts of GMO products. Other arguments, in particular those raised by citizens during EU GMO authorisations, express anger about the perceived arrogance of biotechnology companies to press ahead with a risky new biotechnology, the long-term effects of which are considered as not sufficiently understood. Also empathy is expressed in relation to farmers from developing third countries, such as Argentina, that will be able to access the EU as an export market if the sale of their transgenic agricultural products is authorised. Empathy is also voiced in relation to those who suffer from food shortages in the developing world and who may benefit from a second 'green revolution' based on transgenic agriculture. But emotion discourses are also invoked by scientists, applicant companies and administrators working for the Commission and national competent authorities. They involve appeals to trust in data, science and regulatory regimes.

A preliminary analysis of EU GMO authorisations under Regulation 1829/2003/EC and Directive 2001/18/EC that so far have been completed for twenty GMO products ${ }^{88}$ suggests that emotion discourses invoked by members of the public and those emotion discourses that seek to mobilise fear about the impacts of GM products are marginalised. They are not referred to in the reasons given by the Commission in the preamble to its Decision about the authorisation of a transgenic agricultural product. Their influence on final decision-making seems to be limited given the fact that the overwhelming majority of Commission Decisions grant GMO authorisations. A Foucauldian perspective directs attention to this management of discourses and considers it as key to understanding the exercise of public powers through EU GMO authorisations. Most importantly, it helps to identify a research question that provides an angle for understanding EU GMO authorisations that is different from existing accounts: why are some emotion discourses valorised and others marginalised and how is this achieved? This 
research question opens up the internal dynamics of EU GMO authorisations for analysis. It seeks to understand how ways of arguing for and against transgenic agricultural products become disciplined. In particular, Foucauldian discourse analysis enables to develop four hypotheses.

\subsubsection{Four hypotheses for explaining the disciplining of emotion discourses in EU GMO authorisations}

\section{Disciplining emotion discourses through distinctions between 'normal' and 'abnormal' emotion discourses}

First, the differential treatment of various emotion discourses may not be so much the result of a ranking of different types of knowledge claims, but rather a matter of distinguishing between 'abnormal' and 'normal' emotion discourses. ${ }^{89}$ 'Normal' emotion discourses are associated with the affirmation of scientific arguments for and against the authorisation of transgenic agricultural products. 'Abnormal' emotion discourses question in emotive terms scientific arguments or generate non-scientific arguments, such as arguments based on socio-economic or ethical considerations, in emotive terms. This distinction between 'normal' and 'abnormal' emotion discourses provides an innovative framework for understanding risk regulation, which in the literature is often characterised in terms of distinctions between scientific and non-scientific discourses. ${ }^{90}$ Moreover, a Foucauldian perspective draws attention not so much to the ranking of discourses but to the creation of effects of power of discourses according to whether they are classified as 'normal' or 'abnormal' according to the standards of the communication scenario in which they are invoked.

\section{Valorising 'normal' emotion discourses through associated distinctions between 'expert' and 'lay' participants in EU GMO authorisations}

Whether a particular emotion discourse is valorised or not depends also on whether it becomes associated with a 'lay' participant or 'expert' role. Emotion discourses that invoke trust in scientific data, science itself and regulatory procedures for controlling potential risks posed by transgenic agricultural products generate roles for scientists and administrators, such as to facilitate EU GMO authorisations. These emotion discourses create subject positions that can be taken up by scientists and administrators in EU GMO authorisations. In contrast to this, emotion discourses that question scientific arguments and raise socio-economic or ethical arguments in emotive terms generate roles for lay participants in EU GMO authorisations, in particular citizens during $\mathrm{EU}$ and national public participation procedures. Hence, by generating distinct roles of 'expert' and 'lay' participants a distinction between 'normal' and 'abnormal' emotion discourses 
becomes further reinforced. This questions the differentiation in some of the risk regulation literature between 'expert' discourses associated with nonemotive scientific discourses, on the one hand, and 'lay' discourses linked to emotive, non-scientific discourses, on the other hand. ${ }^{91}$

\section{Valorising 'normal' emotion discourses in order to manage accountability and legitimacy deficits of EU GMO authorisations}

Emotion discourses that invoke trust in scientific data, science itself, and regulatory procedures may be valorised because they stabilise and facilitate existing procedures for EU GMO authorisations and thereby help to manage their current accountability and legitimacy deficits. This hypothesis is grounded in the idea that discourses generate effects of power and constitute social action. The management of accountability and legitimacy deficits through 'normal' emotion discourses matters not just from a 'good governance' but also from a legal perspective. Significant delays in decision-making in relation to EU GMO authorisations and rejections of applications on other than scientific grounds can be in breach of international trade law, in particular the GATT and SPS agreement. ${ }^{92}$ Accountability and legitimacy deficits arise not just from the fact that the Commission mainly decides on its own proposals but also from more specific aspects of EU GMO authorisations. They are highlighted in written submissions from EU citizens in response to EFSA's scientific opinion. For instance, they criticise what they perceive as EFSA's insufficient scrutiny of biotech applicants' risk assessments of transgenic agricultural products. They also criticise EFSA's acceptance of very basic post-release monitoring plans put forward by biotech applicant companies. EU citizens' submissions have also highlighted that the authorisation procedure under Directive 2001/18/ $\mathrm{EC}$ is based on a risk assessment of the transgenic agricultural product carried out by the biotech applicant company which has a commercial interest in a favourable outcome of the authorisation. Accountability and legitimacy deficits are also raised by citizens during national public participation phases in relation to GMO authorisations. For instance, some citizens have complained that their national competent authority had already drafted and sent its national assessment report to the Commission and EFSA before the time period for consultation with citizens - as laid down in national law - had expired.

\section{Valorising 'normal' emotion discourses in the context of the predominance of scientific discourses in EU GMO authorisations}

The fourth hypothesis suggests that the valorisation of 'normal' emotion discourses that invoke trust in data, science and regulatory procedures flows from the predominance of scientific discourses in EU GMO authorisations. Scientific discourses are predominant because they have a clear institutional 
focus, in particular EFSA, and they are amplified through institutional interactions between the Commission and EFSA.

EU GMO authorisations rely to a significant extent on scientific and technical discourses. A Foucauldian perspective can help to explain further why and how this is the case. Discourse is relational in the sense that its meaning is established through its differentiation from other discourses. ${ }^{93}$ Hence, an account of the dominance of technical and scientific discourses in EU GMO authorisations has to include an analysis of how the process of arguing for and against transgenic agricultural products is structured in such a way that socio-economic and ethical considerations are sidelined.

Socio-economic arguments address potential negative distributional impacts upon small farmers who cannot afford GMO seeds and plants. They also refer to limited choice for consumers between conventional, organic and transgenic agriculture and threats to the economic viability of separate conventional and organic agricultural production, due to risks of contamination of conventional and organic crops with GM crops. ${ }^{94}$ EFSA rejects socioeconomic arguments raised by member states and EU citizens in response to its scientific opinions on specific transgenic agricultural products on the grounds that consideration of these is beyond its jurisdiction.

But the Commission may be required to consider them. One of the purposes of Regulation 1829/2003/EC is to 'ensure the effective functioning of the internal market' (Art. 1(a)). ${ }^{95}$ Moreover, Article 7 (1) of Regulation 1829/2003/EC ranks on an equal level three factors for the Commission to take into account when preparing its draft decision on the authorisation of the GMO agricultural product: EFSA's opinion, any relevant provisions of Community law and 'other legitimate factors relevant to the matter under consideration'. The Regulation suggests that the Commission is 'taking into account' these three factors when writing its draft decision. This may be interpreted as a requirement to consider 'other legitimate factors'. But in practice the Commission marginalises these, such as socio-economic arguments. ${ }^{96}$ But not just socio-economic also ethical arguments are sidelined in EU GMO authorisations.

The EU legal framework enables to some extent the consideration of ethical arguments for and against the authorisation of GMO agricultural products. Article 29 (1) of Directive 2001/18/EC addresses the consideration of ethical issues of a general nature in relation to biotechnology. But ethical issues in relation to the authorisation of specific transgenic agricultural products are not explicitly referred to. ${ }^{97}$ Article 33 (1) of Regulation 1829/2003/ EC, however, provides a power for the Commission to consult either upon its own initiative or upon the request of a member state the European Group on Ethics in Science and New Technologies, 'or any other appropriate body it might establish' in order to obtain its opinion on ethical issues. But in practice the European Group on Ethics in Science and New Technologies is 
not consulted in relation to specific GMO applications, only in relation to wider issues, such as the general topic of 'ethics of modern developments in agriculture technologies' ${ }^{98}$

To summarise, technical-scientific discourses are dominant in EU GMO authorisations also because they are differentiated from socio-economic and ethical arguments, which are sidelined. But this relationship between different discourses in EU GMO authorisations is in flux. In December 2008, France, holding the Council presidency, launched an initiative to reform current EU GMO authorisation procedures, so that greater weight would be placed upon socio-economic considerations. ${ }^{99}$ The Commission has responded by commissioning environmental consultants to prepare reports on the current working and possible reforms of EU GMO authorisations. ${ }^{100}$

In order to understand how and why technical-scientific discourses are currently predominant in EU authorisations, they need to be considered in the context of the institutional structures in which they are invoked. Scientific knowledge relied upon during EU GMO authorisations is embedded in political governance structures. The EU legal framework determines to a significant extent who produces scientific knowledge, whose scientific knowledge should count and at what level of governance scientific knowledge should be produced. The discourses generated during EU GMO authorisations are therefore also the outcome of interactions between key EU institutional actors. Regulation 1829/2003/EC provides for an EU-wide, centralised risk assessment carried out by EFSA at the EU rather than national level also in order to overcome member states' distrust of each others' risk assessments. ${ }^{101}$ This particular multi-level governance arrangement under Regulation 1829/2003/EC generates a specific type of technical-scientific discourse. It indicates a preference for harmonised and consensus-based knowledge rather than an open recognition of a plurality of different scientific views of risk in the various member states. Institutions thus generate their own disciplinary practices for the generation of knowledge. ${ }^{102}$

Also the inter-institutional relationship between the Commission and EFSA is significant. EFSA is the main site of technical-scientific discourses in EU GMO authorisations. Its organisational identity is premised upon the idea that it does not take into account other, such as socio-economic or ethical, considerations in its risk assessments. ${ }^{103}$ In practice, the Commission seldom departs from EFSA's mostly favourable opinions in relation to specific transgenic agricultural products for which authorisation is applied for. To conclude, the current dominance of scientific-technical discourses in EU GMO authorisations has to be understood in relational terms as a differentiation from 'other' socio-economic and ethical discourses and within the context of institutional interactions, in particular between EFSA and the Commission. But what can Foucauldian-inspired discourse analysis tell us about the legal dimension of EU GMO authorisations? 


\subsubsection{What can Foucauldian-inspired discourse analysis tell us about the legal dimension of EU GMO authorisations?}

As discussed in section 3.3 above, Foucault's work has already been recognised in theoretical academic commentary as contributing to understanding the role of law in modernity. This argument can be further strengthened if it can be shown that Foucault's ideas can also frame qualitative empirical analysis of 'law in action'. This chapter has suggested that a Foucauldian perspective can unpack how legal actors and EU legislation for the authorisation of transgenic agricultural products are discursively constructed.

More specifically, a Foucauldian perspective can highlight two facets of EU law in relation to GMO authorisations. First, to a limited extent, EU legal provisions for the authorisation of GMOs reflect a juridical conception of power, defined as 'a threshold between two fields of activity' 104 with the threshold either being crossed or not. Distinctions between legality and illegality, for instance, express such a juridical conception of power. The categorical distinction in the formal EC law framework between either authorisation or rejection of a GMO is a further example. Second, EU GMO authorisations reflect a key characteristic of Foucault's conception of modern law, its operation as a 'norm'. Norms are an expression of disciplinary power. They 'may be a maximum which one may hope to achieve' or one may deviate from. ${ }^{105}$ Article 4 (1) (a) of Regulation 1829/2003/EC and Article 4 (1) of Directive 2001/18/EC require that a transgenic agricultural product must not impose adverse effects on human, animal health and the environment before it can be released into the environment or sold on the EU market. Given limited knowledge about the long-term impacts of transgenic agricultural products, in practice authorisations can only indicate different degrees of safety. EU GMO authorisations are thus based on safety as a norm.

This ability of a Foucauldian perspective to capture both the juridical and norm dimension of law matters, because it can further explain how and why GMO administrative authorisation procedures are stabilised and facilitated by law in the light of a potentially glaring democratic deficit. The move towards 'norms' of safety - and thus disciplinary practices for the control of risky biotechnology - diverts attention away from the legitimacy and accountability of the authorisations themselves. Moreover, legitimacy and accountability are governance concepts that are associated with the exercise of juridical power, which is sidelined in EU GMO authorisations. ${ }^{106}$

\subsection{Conclusion: The potential and limitations of Foucauldian-inspired discourse analysis to contribute to critical environmental law scholarship}

This chapter has argued that Foucauldian-inspired discourse analysis can help to generate a critical account of EU GMO authorisations by turning 
the spotlight on an under-researched aspect: the disciplining of emotion discourses invoked in authorisation procedures and in particular the valorisation of 'normal' emotion discourses that invoke trust in data, science itself and regulatory procedures. More empirical research needs to be done that examines the rules of formation of the various discourses invoked in EU GMO authorisations. In order to harness a Foucauldian perspective for the project of critical environmental law scholarship it is also necessary to tackle two potential limitations.

First, law is an obvious field in which to apply Foucault's interest in understanding systems of thought mediated by language. But his approach may unduly narrow the focus on linguistic manifestations of social phenomena even though discourse analysis can also be applied to historical events, policies, ideas as well as organisations. But these other social phenomena are accessed through the study of their linguistic manifestations like policy documents, speeches, reports and interviews. Hence, discourse analysis sidelines 'behaviour' or 'action' ${ }^{107}$ and thus participant observation, otherwise a major research technique in qualitative empirical research which has real potential to contribute to critical scholarship because it allows to collect data about what social actors actually do rather than what they say they do. But discourse analysis does not reduce the social world to language-based phenomena. It simply suggests that a whole range of social phenomena can be understood as analogous to linguistic systems. ${ }^{108}$ Discourse analysis therefore looks for systems of signification not just in linguistic but also other social systems. ${ }^{109}$

Second, perhaps one of the most powerful criticisms of Foucauldianinspired discourse analysis questions its explanatory and critical power on the grounds that Foucault is merely interested in tracing 'contingent associations' or 'conjunctions' in order to explain the social world. ${ }^{110}$ It is not entirely clear what form of explanation the tracing of 'contingent associations' involves but it seems to suggest a departure from unravelling 'causation' in the social world. The potential of Foucauldian-inspired discourse analysis to provide a critique of law and the social relations that underpin it may be limited due to its relativist stance. Whether a statement should be considered as true or false, as valid or invalid cannot be decided with reference to some ultimate values or fundamental structures or primary meaning but is relative and specific to the particular discourses within which it is invoked. There is no essentialist basis for a superior set of 'fundamental values' in discourse analysis. ${ }^{111}$ Hence for some it is questionable whether Foucault's anti-humanist stance can help to develop a progressive, critical agenda in environmental law scholarship. It is clear, however, that Foucauldianinspired discourse analysis can contribute to one of the core aspirations of critical legal scholarship: to develop non-essentialist accounts of the operation of law. To abandon the search for underlying political or economic structures that could explain the operation of environmental law also opens up space for change in environmental law. 


\section{Notes}

1 I would like to thank the John Fell Fund, Oxford University, for financial support of the research on the EU GMO authorisations and the participants in the 'Critical Environmental Law' Symposium, 5 June 2009, at Westminster University, and the participants in the Reading Law School staff seminar, 4 November 2009, for comments on a draft of this chapter.

2 The focus of the chapter is to explore the contribution of Foucauldian-inspired discourse analysis to the development of critical environmental law scholarship, rather than the critical practice of environmental law.

3 For an example of the contribution of feminist perspectives to critical environmental law scholarship see Karen Morrow's chapter in this book.

4 E.g. Richardson, 2000.

5 See, e.g., Kennedy, 1993.

6 E.g. Freeman, 1976; Meidinger, 1989.

7 Gabel, 1980.

8 Collins, 2008: 284.

9 Kennedy and Klare, 1984: 461-62.

10 Elworthy and Holder, 1997: 465-66.

11 See, e.g., the groundbreaking studies by Hawkins, 1984; Richardson, 1982; Richardson et al., 1982.

12 For an analysis of environmental law from the perspective of systems theory see Teubner et al., 1994.

13 Scott, 2009; Lee, 2008. Some studies question the very idea of a 'gap' and have analysed both regulated companies' and regulators' strategies for closing 'gaps' and projecting compliance with environmental law obligations (Lange, 1999: 549-67).

14 For instance, Hawkins (1984) found that strict liability water offences were reinterpreted by water pollution control inspectors as involving negligence.

15 Kelman, 1983: 432.

16 Wheeler, 2008: 1099.

17 Scott and Holder, 2006.

18 Thatcher and Coen, 2008; Scott, 2001.

19 Holder and Harrison, 2002.

20 Castells, 2000: 501.

21 For further discussion of 'localism' in environmental regulation see Wood, 1999; Halfacre and Matheny, 1999 and Jarvis, 1999.

22 E.g. Hilson 2005.

23 E.g. Cullinan, 2003: chapter 14.

24 E.g. Yoichiro, 2003; Goodie, 2001; Varzari, 2001; Litfin, 1995, and in this book Andreas Kotsakis. For an example of combining Foucauldian-inspired discourse analysis with an interpretative approach see Lange, 2005.

25 See http://www.guardian.co.uk/environment/2009/may/13/trafigura-ivory-coastdocuments-toxic-waste. Site last visited 18 May 2010.

26 See, for instance, Greenpeace's successful judicial review challenge of 'sham' consultation procedures in relation to the UK government's review of energy policy: R. on the application of Greenpeace Ltd v Sec. of State for Trade and Industry [2007] Env. L.R. 29.

27 Examples of this are the proliferation of information exchange and governance networks under Article 17 (1) of the IPPC Directive (2008/1/EC), the Common Implementation System under the EU Water Framework Directive (2000/60/EC) and the IMPEL network of enforcement inspectors from different EU member states (Lange, 2010). 
28 Foucault, 1972: 49.

29 Howarth, 2000: 3.

30 McHoul and Grace, 1997: 91.

$31 \mathrm{McHoul}$ and Grace, 1997: 21; Foucault 1997: 59. There are further power effects of discourses, such that they are divided into 'true' or 'false' elements, with 'true' statements being privileged (Howarth, 2000: 56).

32 Hawkins, 1984.

33 Lange, 2008: chapter 8.

34 But Foucauldian perspectives have been further developed through Actor Network Theory (ANT) in order to address how interactions between human actors and technology transform understandings of agency. See Alain Pottage's chapter in this book.

35 Howarth, 2000: 121.

36 Brown and Michael, 2002: 262; Beck, 1992. But a survey conducted by the Environment Agency for England and Wales suggests that trust in its activities is increasing (Macrory, 2004: 26).

37 Hervey, 2001.

38 Fisher, 2007: 245.

39 McHoul and Grace, 1997: 58.

40 Foucault, for instance, distinguishes between different types of sciences according to their levels of positivity, epistemologization, scientificity and formalization. While the natural sciences, such as physics, chemistry and biology clearly have passed the threshold of scientificity and formalization, less formal sciences, such as medicine and the human sciences may not have done so (Howarth, 2000: 59).

41 Thayyil, 2008: 139.

42 Howarth, 2000: 110.

43 Laclau and Mouffe, 1987: 97, 98, 99.

44 Howarth, 2000: 102.

45 Howarth, 2000: 15.

46 Howarth, 2000: 8, 54.

47 Foucault, 1997: 12.

48 Howarth, 2000: 53.

49 Howarth, 2000: 119.

50 Foucault, 1991: 102.

51 Schmidt and Radaelli, 2004.

52 Schmidt and Radaelli, 2004: 193.

53 Schmidt and Radaelli, 2004: 184.

54 Schmidt, 2008: 305.

55 Schmidt, 2008: 314.

56 Schmidt and Radaelli, 2004: 197.

57 Schmidt and Radaelli, 2004: 195.

58 Schmidt and Radaelli, 2004: 195.

59 Golder and Fitzpatrick, 2009.

60 Golder and Fitzpatrick argue against Hunt's and Wickham's idea that Foucault has expelled law from his account of modernity on the grounds that Hunt and Wickham (1994) have failed to distinguish between Foucault's conception of law, on the one hand, and his references to 'juridico-discursive' or 'juridical' power, on the other (Golder and Fitzpatrick, 2009: 35). Moreover, Golder and Fitzpatrick suggest that while there is limited attention to the role of law in modernity in Foucault's earlier work, in his later work on governmentality he does recognise the significant role that legislative activity and the idea of 'laws as tactics' plays in the regulation of modern societies (Golder and Fitzpatrick, 2009: 29, 34). 
61 Golder and Fitzpatrick, 2009: 2, 11.

62 By 'disciplinary power' Foucault refers to behavioural norms that constitute the modern individual and mould it into roles that support specific social orders, such as the productive worker or the dutiful child (Golder and Fitzpatrick, 2009: 18). Foucault, 2007: 55.

63 Golder and Fitzpatrick, 2009: 13.

64 Golder and Fitzpatrick, 2009: 130.

65 Golder and Fitzpatrick, 2009: 72.

66 Ewald, 1990: 138, referring to Michel Foucault's History of Sexuality.

67 Ewald, 1990: 155; Ewald, 1987: 42-49.

68 Ewald, 1990: 156.

69 Ewald, 1990: 155.

70 Golder and Fitzpatrick, 2009: 38.

71 Golder and Fitzpatrick, 2009: 106.

72 Golder and Fitzpatrick, 2009: 2.

73 Golder and Fitzpatrick, 2009: 105.

74 Golder and Fitzpatrick, 2009: 100.

75 For instance, discourse analysis that builds on social psychology (Edwards, 2004) and critical discourse analysis that builds on Fairclough's work (1995). An example of the application of the latter in the field of environmental law is Varzari (2001).

76 Golder and Fitzpatrick, 2009: 3; Foucault, 1981.

77 Howarth, 2000: 10.

78 Howarth, 2000: 115.

79 Howarth, 2000: 118.

80 E.g. Jack, 2009: 227.

81 Regulation (EC) No. 1829/2003 of the European Parliament and of the Council of 22 September 2003 on genetically modified food and feed, OJ L 268/1,18 October 2003.

82 Directive 2001/18/EC of the European Parliament and of the Council of 12 March 2001 on the deliberate release into the environment of genetically modified organisms and repealing Council Directive 90/220/EEC, OJ L 106/1, 17 April 2001.

83 Under Directive 2001/18/EC the applicant biotech company is required to provide the environmental risk assessment, and under Regulation 1829/2003/EC the European Food Safety Authority (EFSA) also carries out a central risk assessment of the GMO.

84 Article 35 Regulation 1829/2003/EC and Article 30 Directive 2001/18/EC.

85 According to the GMO Compass website twenty-eight GMO products had been fully authorized under the new regime established by Regulation 1829/2003/EC and Directive 2001/18/EC by May 2010, see: http://www.gmo-compass.org/eng/ $\mathrm{gmo} / \mathrm{db} /$, site last visited 18 May 2010. In three cases no published Commission decision seems to be available.

86 Edwards, 1999: 288.

87 More problematically the term 'suicide seed' also alludes to Indian farmers who have committed suicide owing to the pressures of debt generated by economic dependence on seed companies that sell sterile GMO seeds (Malone, 2008). Thanks to Paul Almond for pointing this out.

88 EU GMO authorisations include the following documents: the biotechnology company's application, comments from Member States and EU citizens, the opinion of the European Food Safety Authority for applications processed under Regulation 1829/2003/EC, national assessment reports for applications started under Directive 2001/18/EC, opinions of national advisory committees, such as the UK Advisory Committee for Releases into the Environment (ACRE) and the EU Commission's draft and final decisions on the application. 
89 McHoul and Grace, 1997: 68; Ewald, 1990: 140.

90 E.g. Eden, 1996.

91 Wynne, 2001.

92 EC Measures affecting the Approval and Marketing of Biotech Products (DS 291, 29 September 2006).

93 Howarth, 2000: 102.

94 For instance, EU citizens have suggested that authorisation of specific GM products, such as GM maize 1507, will destroy a thriving market in organic GM maize feed production.

95 Only Regulation 1829/2003/EC, not Directive 2001/18/EC, refers explicitly to 'other legitimate factors' in EU GMO authorisations. Article 6 (3) of the Food Law Regulation 178/2002/EC - that also established EFSA - enables 'other factors legitimate to the matter under consideration' to be taken into account in risk management decisions in relation to food safety.

96 Interview with DG Sanco official, 21 November 2008.

97 Article 29 (1) of Directive 2001/18/EC imposes a duty upon the Commission to consult on its own initiative or at the request of the European Parliament the Council or any member state 'any committee it has created with a view to obtaining its advice on the ethical implications of biotechnology, such as the European Group on Ethics in Science and New Technologies, on ethical issues of a general nature'.

98 The European Group on Ethics in Science and New Technologies to the European Commission, Ethics of Modern Developments in Agriculture Technologies, Opinion No. 24, 17 December 2008, at: http://ec.europa.eu/european_group_ethics/ docs/opinion24_en.pdf., site last visited 18 May 2010. Interview with DG Sanco official, 21 November 2008.

99 Council Conclusions, 2008, at: http://www.consilium.europa.eu/uedocs/cms_data/ docs/pressdata/en/envir/104509.pdf, last visited 18 May 2010.

100 For more information about the evaluation of Regulation 1829/2003/EC co-ordinated by DG Sanco see: http://ec.europa.eu/food/food/biotechnology/ evaluation/index_en.htm, last visited 18 May 2010.

101 Lee, 2008: 72.

102 Tadros, 1989: 95.

103 Interview with EFSA official, 16 December 2008.

104 Tadros, 1989: 75, 89.

105 Tadros, 1989: 89.

106 Tadros, 1989: 90.

107 Howarth, 2000: 11.

108 Howarth, 2000: 13.

109 Howarth, 2000: 102.

110 Kendall and Wickham, 1999: 5. Foucault, 2007: 56.

111 Howarth, 2000: 124.

\section{Bibliography}

Beck, U. Risk Society: Towards a New Modernity, London: Sage Publications. 1992.

Brown, N., and Michael, M. 'From authority to authenticity: the changing governance of biotechnology', 4 Health, Risk and Society 3, 259-72. 2002.

Castells, M. The Rise of the Network Society: The Information Age, Vol. I of Economy, Society and Culture, Oxford: Blackwell, 2nd edn. 2000.

Collins, H. 'Critical legal studies', in Cane, P. and Conaghan, J. (eds) The New Oxford Companion to Law, Oxford: Oxford University Press. 2008. 
Council Conclusions, Council of the European Union, Brussels, 5 December, 16882/ 08 Limite, Agrileg 223, ENV 961, 'Genetically Modified Organisms - Council Conclusions'. 2008.

Cullinan, C. Wild Law: A Manifesto for Earth Justice, Totnes: Green Books. 2003.

Eden, S. 'Public participation in environmental policy: considering scientific, counterscientific and non-scientific contributions', Public Understanding of Science, 183-204. 1996.

Edwards, D., 'Emotion discourse', 5 Culture and Psychology 3, 271-91. 1999.

Edwards, D., Discourse and Cognition. London: Sage Publications. 2004.

Elworthy, S., and Holder, J. Environmental Protection: Text and Materials: London: Butterworth. 1997.

Ewald, F., 'The law of law', in Teubner, G. (ed.) Autopoietic Law: A New Approach to Law and Society, Berlin: de Gruyter. 1987.

Ewald, F., 'Norms, discipline and the law', 30 Representations, special issue 'Law and the Order of Culture', 138-61. 1990.

Fairclough, N. Critical Discourse Analysis, London: Longman. 1995.

Fisher, L. Risk Regulation and Administrative Constitutionalism. Oxford: Hart Publishing. 2007.

Foucault, M. The Archaeology of Knowledge. London: Tavistock. 1972.

Foucault, M. 'Questions of method: an interview with Michel Foucault', Ideology and Consciousness 8, 3-14. 1981.

Foucault, M. Governmentality, trans. Rosi Braidotti, rev. Colin Gordon, in Burchell, G., Gordon, C., and Miller, P. (eds) The Foucault Effect: Studies in Governmentality, Chicago: Chicago University Press. 1991.

Foucault, M. 'Society must be Defended', lectures at the Collège de France, 1975-76, in Rabinow, P. (ed.) The Essential Works of Foucault, Vol. 1, Ethics, London: Allen Lane, 59-65. 1997.

Foucault, M. 'The Will to Knowledge', in Rabinov, P. (ed.) The Essential Works of Foucault, Vol. 1, Ethics, London: Penguin Books, 1997.

Foucault, M. 'Spaces of Security: The Example of the Town', lecture of 11 January 1978, from Foucault, Security, Territory, Population, lectures at the Collège de France, 1977-78, trans. Graham Burchell, Basingstoke: Palgrave, repr. 26 Political Geography, 48-56. 2007.

Freeman, A. 'Give and take: distributing local environmental control through land-use regulation', 60 Minnesota Law Review, 883-970. 1976.

Gabel, P. 'Reification in legal reasoning', in Spitzer, S. (ed.) 3 Research in Law and Sociology 25-52, Greenwich, CT: JAI Press, 1980.

Golder, B., and Fitzpatrick, P. Foucault's Law, Abingdon: Routledge. 2009.

Goodie, J. 'The invention of the environment as a subject of legal governance' in Wickham, G., and Pavlich, G. (eds.) Rethinking Law, Society and Governance: Foucault's Bequest, Oxford: Hart Publishing. 2001.

Halfacre, A., and Matheny, A. 'The grassroots at risk: local perceptions and environmental injustice' in Holder, J., and McGillivray, D. (eds.) Locality and Identity: Environmental Issues in Law and Society, Aldershot: Ashgate. 1999.

Hawkins, K. Environment and Enforcement: Regulation and the Social Definition of Pollution, Oxford: Clarendon Press. 1984.

Hervey, T., 'Regulation of genetically modified products in a multi-level system of governance: science or citizens?', 10 RECIEL 3, 321-33. 2001. 
Hilson, C. 'Information disclosure and the regulation of traded product risks', 17 Journal of Environmental Law 3, 305-22. 2005.

Holder, J., and Harrison, C. Law and Geography, Current Legal Issues 5, Oxford: Oxford University Press. 2002.

Howarth, D. Discourse, Buckingham: Open University Press. 2000.

Hunt, A., and Wickham, G. Foucault and Law: Towards a Sociology of Law as Governance, London: Pluto Press. 1994.

Jack, B. Agriculture and EU Environmental Law, Farnham: Ashgate. 2009.

Jarvis, F. 'Save as you spend: consumer protection of the environment and local social cohesion' in Holder, J., and McGillivray, D. (eds.) Locality and Identity: Environmental Issues in Law and Society, Aldershot: Ashgate. 1999.

Kelman, M. 'The past and future of legal scholarship' 33 Journal of Legal Education 432-36, 1983.

Kendall, G., and Wickham, G. Using Foucault's Methods. London: Sage Publications. 1999.

Kennedy, D. Sexy Dressing, etc. Cambridge MA: Harvard University Press. 1993.

Kennedy, D., and Klare, K. 'A Bibliography of Critical Legal Studies', 94 Yale Law Journal, 2, 461-90. 1984.

Laclau, E. and Mouffe, C. 'Post-Marxism without Apologies', New Left Review, Nov.-Dec., 79-106. 1987.

Lange, B. 'Compliance construction in the context of environmental regulation', 8 Social and Legal Studies, 4, 549-67. 1999.

Lange, B. 'Researching discourse and behaviour as aspects of law in action', in Banakar, R., and Travers, M. (eds), Theory and Method in Socio-legal Research, Oxford: Hart Publishing. 2005.

Lange, B. Implementing EU Pollution Control: Law and Integration, Cambridge: Cambridge University Press. 2008.

Lange, B. 'Thinking about procedure: understanding legitimacy in EU environmental governance networks', in Dilling, O., Herberg, M. and Winter, G. (eds) Transnational Administrative Rule-Making: Performance, Legal Effects, and Legitimacy. Oxford: Hart Publishing. 2010.

Lee, M. EU Regulation of GMOs: Law and Decision Making for a New Technology. Cheltenham: Edward Elgar. 2008.

Litfin, K. 'Framing science: precautionary discourse and the ozone treaties', $24 \mathrm{Mil}$ lennium Journal of International Studies, 251-77. 1995.

Macrory, R. 'Transparency and trust: reshaping environmental governance in Northern Ireland', Centre for Law and the Environment, Faculty of Laws, University College London, London, at http://www.ucl.ac.uk/laws/environment/docs/NI_report. pdf 2004.

Malone, A. 'The GM genocide: thousands of Indian farmers are committing suicide after using genetically modified crops', Daily Mail, 3 November 2008, at http:// www.dailymail.co.uk/news/worldnews/article-1082559/The-GM-genocide-ThousandsIndian-farmers-committing-suicide-using-genetically-modified-crops.html.

McHoul, A., and Grace, W. A Foucault Primer: Discourse, Power and the Subject. New York: New York University Press. 2003.

Meidinger, E. 'The Development of Emissions Trading in US Air Pollution Regulation', in Hawkins, K., and Thomas, J. (eds), Making Regulatory Policy, Pittsburgh PA: University of Pittsburgh Press. 1989. 
Richardson, B. 'Environmental law in postcolonial societies: straddling the localglobal institutional spectrum', 11 Colorado Journal of International Environmental Law and Policy 1, 1-82. 2000.

Richardson, G. 'Policing pollution: the enforcement process', 11 Policy Studies Journal 1, 153-164. 1982.

Richardson, G., Ogus, A., and Burrows, P. Policing Pollution: A Study of Regulation and Enforcement, Oxford: Clarendon Press. 1982.

Schmidt, V. 'Discursive institutionalism: the explanatory power of ideas and discourse', 11 Annual Review of Political Science, 303-26. 2008.

Schmidt, V., and Radaelli, C. 'Policy change and discourse in Europe: conceptual and methodological issues', 27 West European Politics 2, 183-210. 2004.

Scott, C. 'Analysing regulatory space: fragmented resources and institutional design', Public Law, summer, 329-53. 2001.

Scott, J. (ed.). Environmental Protection: European Law and Governance, Oxford: Oxford University Press. 2009.

Scott, J., and Holder, J. 'Law and new environmental governance in the European Union', in DeBurca, G., and Scott, J. (eds), Law and New Governance in the EU and the US, Oxford: Hart Publishing. 2006.

Tadros, V. 'Between governance and discipline: the law and Michel Foucault', 18 Oxford Journal of Legal Studies 1, 75-103. 1989.

Teubner, G., Farmer, L., and Murphy, D., Environmental Law and Ecological Responsibility: The Concept and Practice of Ecological Self-organization, Chichester: Wiley. 1994.

Thatcher, M., and Coen, D. 'Reshaping European regulatory space: an evolutionary analysis', 31 West European Politics 4, 806-36. 2008.

Thayyil, N., 'Deliberative turning from a law-science cul-de-sac: speculations regarding community transgenic regulation', Yearbook of European Environmental Law, 133-61. 2008.

Varzari, J. 'Revealing of Remedying Discrimination? Critical Discourse Analysis and Environmental Law in Alberta', M.A. thesis, University of Calgary, at https:// dspace.ucalgary.ca/handle/1880/40941. 2001.

Wheeler, S. 'Socio-legal research' in Cane, P., and Conaghan, J. (eds) The New Oxford Companion to Law, Oxford: Oxford University Press. 2008.

Wood, D. 'Challenging the ethos of the European Union: A Green perspective on EU policies and programmes for rural development and the environment' in Holder, J., and McGillivray, D. (eds), Locality and Identity: Environmental Issues in Law and Society, Aldershot: Ashgate. 1999.

Wynne, B. 'Creating public alienation: expert cultures of risk and ethics on GMOs', 10 Science as Culture 4, 445-81. 2001.

Yoichiro, U. 'Evolving environmental norms in the European Union', 9 European Law Journal, 1, 69-87. 2003. 


\title{
The ecological narrative of risk and the emergence of toxic tort litigation
}

\author{
Jo Goodie
}

\section{I Introduction}

Legal understanding of the environment is contingent; it is shaped by the law's interface with a range of non-legal discourses and ideas. Attempts to govern the environment have stretched and unsettled legal orthodoxy. The environment, as a legal object, is not simply a physical space; it is a contingent and instrumental object, determined by human activity, social values, and legal and non-legal calculations. The environment does not fit readily into any of the usual categories pertaining to legal rights and interests.

The 'environment' acquires its meaning through the continuous interchange of the many differently located understandings and attempts to define and articulate environmental entities, ideas and problems. Since the midtwentieth century, ecology, in synthesising ethics and ecological science, has become the dominant means of understanding the environment and environmental health. ${ }^{1}$ Although it began to emerge much earlier, from the midtwentieth century an environmental way of thinking has shaped the ways in which humans live, work, and recreate. In turn the environment has been defined and limited by patterns of individual and collective consumption. These patterns of consumption have placed certain environments at risk, and have created toxic environments that have become an object of 'risk anxiety'.

This chapter considers the law's delineation of toxic environments, through an analysis of how the common law has assimilated the vocabulary and techniques of risk calculation in the legal assessment of environmental harm and hazard in toxic tort litigation. The chapter consists of seven main sections. The first of these, section 4.2, outlines the emergence of an ecological narrative through which the notion of environment is articulated and acted upon. The second, section 4.3, considers how risk, which is itself the product of a complex of rationalities from the scientific and economic through to the anti-materialism of ecologism, is central to the ecological narrative. A heterogeneous range of risk calculations, vocabulary and techniques have been taken up to articulate and delimit the characteristics of specific environments, and to shape the manner in which we interact with, and within, those 
environments. Section 4.4 discusses the significance of toxic tort litigation, a modern variant of common law actions in negligence and nuisance, initiated by plaintiffs exposed to one of the ubiquitous, but often hidden, toxic hazards of the post-industrial society. The remaining four sections $4.5-8$, analysing how environmental hazards are interpreted, understood, acted upon (or ignored) by the law in toxic tort claims, consider the insurantial, scientific, clinical and commonsense practices of risk. ${ }^{2}$

\subsection{Ecological narrative}

Modern environmental understanding has emerged through the application of technical scientific knowledge, rendered more meaningful through various interpretive frameworks of 'environmental sensibility', which treat the environment, not as a thing, but as a dynamic process of which humans are a part, which has a history, an economy, and a power to transform and be transformed. The ecological narrative through which the environment has been identified and become an object of legal attention embraces two distinct rationalities, the moral agendas and discourse of ecological ethics, and the economic model of scientific ecology. ${ }^{3}$

The emergence of the life sciences and biological discipline comprised various features that impacted upon the calculation, description and understanding applied to the environment, in terms of the explanation or problematisation of nature. Whereas the Nature of the Enlightenment scientist was a wholly material world of things, the ecological narrative, through which contemporary understanding of the 'environment' is constituted, emphasises the relationships and interactions between things. Initially, ecological science theorised and modelled natural systems as tending towards equilibrium; this quite mechanistic and rational understanding began to shift in the 1970s in the face of chaos theory and alternative modelling. A 'new ecology' emerged which understands the operation of natural systems in terms of 'the possibility of instability, variability and uncertainty'. ${ }^{4}$ Epidemiologist Tony McMichael argues that unlike the traditional scientific disciplines contemporary ecological science:

embraces the complex interplay between animate and inanimate components; it studies dynamic, non-equilibrial and non-linear processes. ... To an ecologist the world is neither deterministic nor randomly unpredictable; rather, it is a world of contingent probabilities within mutually adapted, self-ordering systems. ${ }^{5}$

Since the mid-twentieth century, ecology, which synthesises a body of ethical thinking as well as a specifically ecological science, has become the predominant means by which the environment and environmental health are interpreted and understood. ${ }^{6}$ As well as underwriting and inspiring the ethic 
of environmentalism, this ecological rendering of the environment has had practical and political significance. It has identified the 'environment' as a special focus of government, rather than a physical space that is simply the site of public health interventions or population resource dilemmas. The scientific conceptualisation of the 'eco-system' and the theoretical and technical focus of ecological science upon 'energy flows within a closed system' has shaped and modelled our practical scientific engagement with the natural world. ${ }^{7}$ While Humboldt, Darwin and their peers first observed and attempted to map the natural world as a complex of discrete yet interconnected 'environments', their scientific investigations, and many of those that followed, were inherently limited by dependence upon large-scale physical observation and data collection. ${ }^{8}$ Ecological systems modelling has allowed the pragmatic investigation of the interconnectedness of the global environment by simulating the various functions and activities of specific ecosystems, making it possible to efficiently conduct macro-calculations of environmental conditions, the impact of resource exploitation or levels of degradation caused by industrial development. Such scientific knowledge in combination with other knowledges, especially from the social sciences, has led to certain problematisations of the environment, notably the extent of human dependence upon and the limitations of human capacity to control the natural world or the hazards produced by human activity. The extent and pervasiveness of anthropogenically produced environmental hazard is uncertain: while scientific investigation may have initially identified toxins accumulating in the environment, the capacity of science to readily identify the source and extent of environmental harm and toxic risk is limited and often compromised by the 'parochial methods and models' of science itself. ${ }^{9}$ This uncertainty persists across dimensions; environmental risk is not confined by 'geographical (or jurisdictional) boundaries, temporal (or limitation) links and social (duty) relationships between those creating the harm and those who are victims of it'. ${ }^{10}$

\subsection{Disclosing the 'risk' environment}

Risk has become an idiom through which the environment is made 'thinkable' and 'amenable to political deliberations'. The refiguring of environmental uncertainties as probabilities; as 'risks' that can be calculated and managed, sustains the moral, as well as the highly rationalised and technical, aspects of contemporary understandings of the environment. ${ }^{11}$ Paul Rutherford argues that:

the relationship of society to the natural environment is conceived in terms of the language of security and risk; ecological hazards and insecurity must be addressed by putting in place behaviours that minimize risk. ${ }^{12}$

The 'risk idiom' produces its own form of what Michel Foucault would call 'bio-political' and 'bio-economic' reality which shape the ambition (and 
the limits) to control ecological hazards and maintain environmental security. ${ }^{13}$ In various ways, modern environmental governance is shaped by 'risk calculations', these calculations are heterogeneous; the technologies through which risk is articulated are not uniform, and the domains of risk-based governance are diverse and underwritten by similarly diverse conceptions of risk. ${ }^{14}$ Eco-systems along with environmental and human health are mapped and governed through specialist calculations as varied as epidemiology, environmental impact assessment, and protocols for 'scoping' corporate greenhouse gas emissions, ${ }^{15}$ which evaluate the 'risk-weighted consequences' of activities and resource use that have the potential to impact on environmental well being. This form of 'regulatory ecological science does not so much describe the environment as both actively constitute it as an object of knowledge and, through various modes of positive intervention, manage and police it'. ${ }^{16}$ It is these types of calculations and methodologies that are taken up by environmental administrators (as well as tribunals and courts when there is dispute) to make informed calculations of environmental wellbeing.

In pointing to the significance of risk as a means of understanding and acting upon the environment, I am observing, as many governmentality theorists have done, that the institutional spread of risk-focused governance has produced certain approaches to understanding and acting upon the environment. ${ }^{17}$ The predominance of certain forms of scientific risk methodology has not excluded other types of environmental assessment. Risk analyst Aynsley Kellow argues that '[e]nvironmental issues inevitably entail questions of both morality and practicality ... There is no objective scientific basis for public policy in general and environmental policy in particular. ${ }^{18}$ Shifts in societal attitude to risk increasingly impact upon legal attitudes and processes, the governmentality approach adopted here facilitates a closer examination of how the law engages with and assimilates various discourses and practices of risk.

\subsection{Toxic tort}

In the wake of the possibility of identifying the effects of exposure to toxic substances and tracing their synergistic effects, the common-law principles of negligence and nuisance, originally developed in the nineteenth century in response to the new hazards of the industrial age, have been adapted (in the form of toxic tort) to offer a remedy in the face of a new set of previously unknown hazards. ${ }^{19}$

Toxic tort litigation is one of the fora in which factors which 'make the environment an important concern for individuals' are articulated. ${ }^{20}$ It provides a vehicle for discerning the relationship between body, hazard and environment. ${ }^{21}$ Actions in toxic tort endorse and articulate risk anxiety, particularly in those instances where the litigation gives publicity to latent hazards and the risk of exposure to those hazards, which had previously been little known in the public domain. ${ }^{22}$ As Ulrich Beck observes: 
Dangers, it would seem, do not exist 'in themselves', independently of our perceptions. They become a political issue only when people are generally aware of them; they are social constructs which are strategically defined, covered up or dramatized in the public sphere with the help of scientific material supplied for the purpose. ${ }^{23}$

Through its key processes of investigating, judging and reporting on the effects of toxic exposure or the hazardous nature of certain environments and environmental practice, toxic tort litigation reveals the pervasiveness of certain environmental risks. ${ }^{24}$ Toxic tort litigation goes beyond simple identification of a hazard and the risk associated with exposure to that hazard. Indeed the court relies on the application of risk technologies to translate the circumstances of a plaintiff's exposure into a justiciable form. It is the incorporation and reliance upon scientific forms of evidence, such as the actuarial forms of risk assessment of the epidemiologist and the engineer, that have allowed the courts to assume a role of disinterested, yet authoritative, arbiter on risk. But the court does more than consider risk in these technological terms: a closer consideration of toxic tort litigation reveals that while parties must be able to point to objective, technical or scientific risk assessment which support their claim or defence, the success of a plaintiff's or defendant's case will also be determined by evidence of other non-scientific, and quite subjective, calculations of risk. The focus of the litigation is the plaintiff's situated and particular experience of a defined local environment, as well as commonly held attitudes to managing environmental risk, which assumes the plaintiff, not just the defendant, is an informed and 'rational' individual, both risk aware and averse.

Pat O'Malley's ${ }^{25}$ depiction of the three manifestations of risk in the legal domain is useful in delineating how risk operates in toxic tort litigation. The harm caused by exposure to a toxic hazard is the object of the litigation, the purpose of which is to assign responsibility for the management of risk taking; techniques of risk assessment are employed in the litigation to determine the limits of legal liability; and the risks revealed and assessed through the litigation are assigned moral value, the application of the principles of negligence or nuisance either privilege or seek to limit those risks. It is through the litigation's multi-layered assessment of the risk that the environment is situated as a 'complex moral problem invoking notions of value and responsibility'. 26

\subsection{Insurantial practices of risk}

Jane Stapelton observes that the increasing 'public policy reliance' on a prudential response to risk has been paralleled by 'a general broadening of the catchment of situations recognised by the courts as giving rise to tort entitlements'. ${ }^{27}$ The prevalence of liability insurance has transformed 
the law of tort in one other respect as well. It has tended to marginalise individual responsibility as a factor determining the outcome of a claim. Morton Horwitz argues that '[1]iability for injury has become just another cost of doing business, which could be estimated, insured against, and ultimately included in the price paid by the public'. ${ }^{28}$ If one is talking about the standard personal injury claim then Horwitz's assessment of the trajectory of tort litigation is reasonable. John Fleming observes that a defendant's insurance may very likely undermine any deterring or punishing effect. ${ }^{29}$ But examination of toxic tort litigation highlights the continuing significance of individual responsibility as the basis for determining liability.

The availability of liability insurance allows the system of tort law to function but does not make redundant the legal assessment of toxic harm, namely how it came about and what injuries it caused. François Ewald holds that the law and insurance each provide a means of assigning responsibility and making compensation for loss, and that the rationality of each may be applied to the same object to different ends. He says, 'Insurance and law are two practices of responsibility which operate quite heterogeneous categories, regimes, economies; as such, they are mutually exclusive in their claims to totality. ${ }^{30}$ The fundamental difference between the two is that the juridical focus on the occurrence of an event is singular and moral. By contrast, the insurantial approach eschews any question of moral responsibility, and instead factors the probability of such an event occurring and recurring in a predictable rule-like fashion. ${ }^{31}$

Insurers may have a capacity through the rule of subrogation to dominate the litigation process, but they do not litigate as if factors beyond their own actuarial calculations are irrelevant. Courts must weigh up competing accounts of the type of risk to which the plaintiff was exposed. These accounts come from the parties themselves, as well as from experts who provide technical assessments of the degree of risk to the plaintiff of the particular toxic exposure, and also from other lay witnesses, such as workmates, whose role is to provide the court with a real appreciation of the environment in which the plaintiff was exposed to risk.

\subsection{Scientific practices of risk}

Expert scientific evidence relating to causation, and the risk presented by exposure to a particular toxin, toxic event or environment, is an integral part of all toxic tort litigation. It provides the evidence of possibility which courts use to map a global picture of the potential hazards to which a plaintiff may have been exposed. Unlike tort litigation of the nineteenth century, which was premised on the assumption that there is usually a single line of causation linking the defendant's negligence and the plaintiff's injury, in contemporary toxic tort establishing a causal nexus between the plaintiff's injury and 
exposure to a toxic environment is much more complex. In toxic tort cases, the model employed to determine the actual cause of the injuries is not based on direct causality but on a 'multi-factor' approach which understands 'the problem of health in a broader context' whereby 'disease can be attributed to exposure to a variety of toxins as well as the lifestyle and patterns of consumption of plaintiff themselves' ${ }^{32}$ Through the application of such an approach, ill health, disease or injury suffered by the individual is inherently referable to the health of the broader environment. The emergence of toxic tort as an identifiable class of litigation has followed developments in science which have allowed the causes of certain diseases and the side effects of exposure to certain types of chemicals and other toxic substances to be identified. ${ }^{33}$ Although these advances in scientific diagnostics and epidemiology have allowed the possibility of attributing legal liability, establishing that there is a causal link between the toxic exposure and the injury is often speculative at best:

In most toxic tort cases, one or more of these elements is contested ... the state of knowledge with respect to many toxic agents is extremely imperfect ... what is known about a chemical from the general scientific literature almost always has to be supplemented by knowledge acquired about particular individuals and communities of claimants. ${ }^{34}$

The identification and delineation of a toxic environmental hazard is multilayered. As Valverde et al. observe, conceptions of risk are by necessity conflated in toxic tort litigation. ${ }^{35}$ Scientific evidence must be strategically framed by other types of evidence. Evidence such as epidemiological calculations of risk is not created for legal purposes; rather, the parties and the court itself must translate, and consequently transform, the evidence before it can be usefully taken up in the litigation. Indeed, the Australian courts freely acknowledge:

The pragmatic assessment of probable cause as a basis for tortious liability cannot be wholly constrained by the scientific and philosophical purity of epidemiology, which essentially depends upon a comparison of the data obtained in controlled circumstances. ${ }^{36}$

Jenny Steele notes that the court employs a decision-making model which 'constructs a moment of decision which may be purely hypothetical' (knowledge of the risk which exposure to the toxin presented at the time of the plaintiff's exposure) 'and uses this to draw the "right" conclusion' (whether the defendant should have known of the risk and whether the exposure is likely to have caused the injury). ${ }^{37}$

That approach to evaluating and positioning epidemiological accounts of risk is apparent in the leading case of Seltsam v McGuiness (hereinafter 
Seltsam). The New South Wales Court of Appeal held that epidemiological studies 'should be regarded as circumstantial evidence which may, alone or in combination with other evidence, establish causation in a specific case'. The court recognised epidemiology's 'potential utility' in toxic tort cases, because it may be able to 'fill the gap' where 'medical science cannot determine the existence or non-existence of a causal relationship for purposes of attributing legal responsibility'. ${ }^{38}$ In Chief Justice Spigelman's words, epidemiological calculations of risk combine with other evidence like 'strands in the cable', allowing the court to infer a causal nexus between the plaintiff's injuries and the toxic exposure as a matter of 'commonsense'. ${ }^{39}$ But whose commonsense? What counts as common sense in toxic tort litigation? The manner in which scientific disciplines, such as epidemiology, conceive of and articulate risk, necessarily impacts upon the court's conception of the risk, Jasanoff observes that the exercise of the court's discretion (its 'common sense') is inevitably shaped by the degree to which 'judges are swayed by their perceptions of what "science" is and who is a "scientist" when they certify an expert's credibility'. ${ }^{40}$

The degree to which a court aligns 'legal causation with scientific causation' not only determines what type of science will count in the litigation, but it also impacts upon the significance and weight attached to other forms of non-scientific evidence. ${ }^{41}$ Debate about the proper interpretation of the US Supreme Court's ruling on the standards that should apply in determining the admissibility of scientific expert evidence in Daubert $v$ Merrell Dow Pharmaceuticals Inc. (hereinafter Daubert) ${ }^{42}$ demonstrates how assessments of risk such as those produced by epidemiologists are not neutral elements in the legal assessment of risk. Daubert reforms have locked out plaintiffs who have based their claim on 'reliable, but not ideal, scientific evidence'. ${ }^{43}$ Edmunds and Mercer point to the failure of one of the first cases relating to the risk of mobile phone use, in support of the argument that:

Daubert-inspired quests to establish scientific truth ... may assist in discouraging ongoing legal scrutiny of intransigent scientific controversies involving uncertain risks. ${ }^{44}$

The debate regarding the proper interpretation of Daubert is more than just what type of science is to be recognised in the court room. Rather, it concerns 'the social and moral viability of particular technological choices' ${ }^{45}$ The trajectory of the Daubert ruling has been to shift the court's attention away from a holistic focus, in which the 'scientific evidence supports a claim framed in lay terms', towards what Karen Morrow in her analysis of British and Irish nuisance cases has labelled a 'harder' approach to causation, in which the evidence of the plaintiff is marginalised in favour of scientific evidence. ${ }^{46}$ 


\subsection{Clinical practices of risk}

The main consideration of much risk commentary in the social sciences is how risk is produced by collective anxiety and politics, ${ }^{47}$ or as a function of certain forms of scientific or actuarial calculations. ${ }^{48}$ When legal commentators consider the function of risk assessment in litigation, their focus also tends to be on actuarial or other scientific calculations of risk. It is a literature that is rarely interested in how the individual actually copes with, engages with, or is affected by risk.

The clinical approach to thinking about risk, which is prevalent in public health programmes, is taken up in this argument because of its focus on the relationship between expert assessments of risk and the individual as an individual (rather than simply as a member of a risk prone population). The clinician, working on the basis of 'probabilistic indicators of future conditions' or 'risk' to a certain type of patient's health, develops a programme of intervention aimed at minimising these risks. ${ }^{49}$ Despite the broader risk discourse within which any toxic tort litigation takes place, the individual litigating parties are the primary focus of the court. ${ }^{50}$ It is the courts' appreciation of the parties' personal and quite specific experience and exposure to risk, and their behaviour in the face of such exposure, which in large part determines the outcomes of a toxic tort suit. It is suggested here that the clinical risk approach highlights the manner by which the toxic tort litigation constructs a certain type of legal subject, in as much as the success of the plaintiff's case will be in part determined by whether the plaintiff is able to situate themselves as risk averse or irresponsible in the face of known risk. ${ }^{51}$

\subsection{Commonsense practices of risk}

We tend to understand risk in terms of its common or everyday meaning rather than as an actuarial calculation or an object of scientific analysis. In its common, everyday sense 'risk' is a term used to describe danger or hazard. ${ }^{52}$ Risks of this kind are not statistical calculations but sociocultural constructs. Such ideas of risk often have their genesis in a scientific prediction of risk, but have been developed to encompass an array of popular knowledge, beliefs and practices that are not limited by the confines of scientific discourse. ${ }^{53}$ There are two principal ways in which everyday or commonsense understandings of risk impact on the evaluation of a toxic tort claim: first, the plaintiff's particular experience of the toxic exposure and its consequences (matters to which the court pays considerable attention) are necessarily shaped by common or everyday understandings of risk; second, risk in its commonly understood sense is assessed in terms of moral culpability and blame, which imposes responsibility to be risk averse on the plaintiff as much as the defendant. 
Robert Lee argues that: "the public experience of risk is not one of unthinking acceptance of a position expounded by experts, nor is it a simple choice between expert positions'. ${ }^{54}$ Research by cognitive psychologists has demonstrated that,

'lay' people evaluate health and environmental threats according to a different set of criteria than may be reflected in expert assessments. ... the risk perception of lay members of the community appears to be influenced by various contextual factors that lie outside the realm of scientific research. ${ }^{55}$

These factors include: familiarity with a technology, the degree of control which can be asserted over it, and the potential for the application of the technology to have catastrophic effects. Notwithstanding the trend in some post-Daubert litigation in the United States, these everyday calculations of risk resonate in toxic tort litigation as well: the risk the toxic exposure exposed the plaintiff to is not judged according to scientific evidence alone. Sheila Jasanoff observes that in toxic tort litigation the courts tend to

favour a holistic (or medical) to a reductionist, or toxicological model of illness. The holistic view focuses on the suffering individual and asks whether, given the totality of circumstances, this person could have been affected in the stated way by the stated exposure ... this approach presumes that issues of general or specific causation must be addressed together, within the context of the plaintiff's lived life. ${ }^{56}$

In Chappel v Hart the Australian High Court candidly observed that causation is 'a question of fact resolved as matter of commonsense and experience, the conclusion is often reached intuitively'. ${ }^{57}$

Fear, or what Mary Douglas would label the plaintiff's 'risk anxiety', is not an accepted basis for a toxic tort claim. The plaintiff must prove actual physical, mental or economic damage. ${ }^{58}$ Nevertheless, evidence of how the plaintiff has responded to toxic exposure, and the risks that exposure presents, are part of the particulars of the case which impact on the court's 'intuitive' and 'commonsense' assessment of the plaintiff's claim. For example in the case of Maddalena $v$ CSR Ltd and another, the significance the court placed on the plaintiff's subjective appreciation of the consequences of his exposure to asbestos is apparent in its judgment for the plaintiff; the court quoted from the transcript of expert psychiatric testimony which highlighted and detailed the plaintiff's anxiety and fear in the face of a risk increasingly made real:

In my opinion Mr Maddalena lives in fear of death from mesothelioma as a result of his undoubted heavy exposure to asbestos some twenty-five 
or so years ago. He has watched his brother and numerous colleagues die severe, painful and lingering deaths. He suffers from chronic fear. ... He cannot be described as cancerphobic because the term phobic implies no real reason for such a belief. I believe that he has compelling reality and emotional reasons for his belief. ... There has been further accretion of anxiety and fear since the objective demonstration of left lung pathology in the early 1990s. ${ }^{59}$

Whereas the technical calculations of epidemiological risk are treated as objective rather than moral assessments by the courts, everyday notions of risk are a basis for ascribing moral culpability. The fact that expert calculations of risk tend to produce an amoralisation of the dispute does not necessarily preclude non-expert understandings of risk also informing an assessment of liability. ${ }^{60}$ Together with an expectation that the individual will monitor him or herself and be risk-averse, risk in its commonly understood sense has become inextricably linked with blame. ${ }^{61}$ Risk, in modern society, has come to replace the old-fashioned (and in modern secular society now largely discredited) notion of $\sin$ as a term that 'runs across the gamut of social life to moralize and politicise dangers' ${ }^{62}$ The knowability of risk, underpinned by the scientific capacity to identify hazardous activities and substances, imposes responsibility not only on hazard creators but also upon potential victims of such hazards. While the focus of an action in tort is the extent of the defendant's responsibility for the plaintiff's injury, Peter Cane observes that the conduct of the plaintiff is also significant:

Tort law is concerned with people's responsibility for their acts and omissions. And because it deals with interactions between people, it contains principles relevant not only to the conduct of injurers but also to the conduct of victims. ${ }^{63}$

The very fact that toxic tort actions are necessarily premised on what Cane labels the 'correlativity' of the parties, may make them an uncertain prospect if a plaintiff is not able to convincingly argue their moral claim to compensation. Lee, developing Cane's analysis, contends that liability in tort is determined in the context of certain assumptions about socially appropriate conduct; tort law is a means of enforcing 'social rules' ${ }^{64}$ As former Australian High Court Justice Michael McHugh has observed, the application of tort doctrine 'depend not only upon the ascertainment of facts but on a moral and social evaluation of those facts' ${ }^{65}$ For the toxic tort plaintiff, who has been the victim of exposure to a lethal toxic substance in circumstances where others, who had responsibility for their well-being, knew the plaintiff was at risk, the opportunity of a 'day in court' is an opportunity for the moral rightness of their claim to be recognised. Plaintiffs have often been prepared to take their case to trial, even in the last months of their life, 
because they wished to salvage something from their untimely death. Compensation to provide some sort of economic security for their family is no doubt important, but a public vindication that they, and people like them, have been unnecessarily and sometimes callously harmed seems in many cases to be a prime motivation, or at least justification for choosing to litigate rather than settle. It is not being argued here that a court deciding a toxic tort suit necessarily frames its decision solely in terms of the moral culpability of the parties. However, blame and responsibility are central to the discourse within which the case is argued and considered.

The allocation of blame and the finding of liability are influenced by subjective assessments of the moral character and reputation of the litigants. Rabin has observed that there are two different types of plaintiffs in toxic tort litigation, those who are characterised as victims and those who are seen as irresponsible. ${ }^{66}$ Credit is not only at issue in criminal cases; lawyers representing plaintiffs harmed by exposure to toxic substances or hazardous activities use the tactic of the public trial for plaintiffs who have acted responsibly and as far as possible protected themselves against harm. A test case plaintiff is not an individual who has voluntarily courted risk. Liability in toxic tort cannot be assessed outside the context of the broader cultural values about risk taking. On this point, the relative success of two of the most ubiquitous categories of toxic tort, tobacco and asbestos litigation, is instructive. The difference between the relative successes of the asbestos and tobacco toxic tort litigation does not lie in the scientific evidence, as there is a wealth of evidence available regarding the toxic nature of exposure to both asbestos and tobacco. The relative success of each type of tort is founded in the circumstances in which each type of toxic exposure typically occurs - that is, on the individual's attitude to risk and the care and responsibility the individual has taken for him or herself. A plaintiff who has been exposed to asbestos has usually not been in a position or circumstance that allowed them to voluntarily limit their exposure, or even know that they were at risk. By contrast, a smoker plaintiff can be readily characterised as irresponsible, as someone who has not heeded health warnings. Rabin observes this is the case even though the plaintiff could call expert evidence relating to the health effects of smoking or the addictive nature of smoking to support their case. Expert evidence loses its persuasive power and becomes abstract and esoteric in the face of more compelling and real evidence of how the plaintiff actually lives and how they have failed to quit smoking despite being aware of the health warnings about tobacco use. ${ }^{67}$

This focus on the credibility of the plaintiff operates in other toxic tort litigation as well. In their study of several actions relating to the toxic contamination of land and urban housing Toffolon-Weiss and Roberts observe that many of the plaintiffs in those cases were poor and with limited access to quality health care. As a result they had only a limited appreciation of the factors that posed a risk to health. The credibility of these plaintiffs' claims can be readily undermined because the plaintiffs: 
may have been exposed to dangerous work and lifestyle factors that are often presented by the defense as alternative causative factors. Government and corporate officials do not take the symptoms of these people seriously. They attribute the poor health of these communities to unhealthy lifestyles (e.g. eating fatty foods, smoking, drinking alcohol and taking drugs). ... Further, middle class jurors' own prejudices may affect their judgments when viewing poorer individuals with different life experiences. $^{68}$

Karen Morrow's analysis of the nuisance cases in Ireland and England shows a similar approach. Farmers who complained that their health and that of their livestock was affected by toxic emissions had to counter claims that their illness was attributable not to the defendant but to their own unhealthy lifestyle and poor farming practices. ${ }^{69}$ In some cases the causal link between the toxic emissions and damage the plaintiff suffered may well have been tenuous, but the point is that the plaintiff is unlikely to succeed unless she or he can demonstrate they have been risk-aware and risk-averse.

\subsection{Conclusion}

The environment is made 'thinkable' and amenable to different types of legal deliberations through the figure of risk. Analysis of toxic tort litigation provides the opportunity for examining the nexus between the conceptualisation of risk and the legal domain. In judging a toxic tort case the court assesses evidence of the environmental conditions that caused harm to the plaintiff and considers how the plaintiff and others typically functioned in that environment and what sort of calculations they made of any environmental risk; it is in assessing this evidence that a certain form of environmental space and problems are revealed or identified by the litigation. But as Steele observes common use of the term 'risk' obscures the significance of the different forms of risk assessment in toxic tort litigation. ${ }^{70}$ There are at least four interrelated conceptions of risk operating - the scientific, the insurantial, the clinical, and everyday or commonsense notions of risk. The clinical approach to thinking about risk commonly employed in public health programmes is taken up because it allows the analysis to focus on how scientific and technical calculations of risk are conflated with everyday or commonsense notions of the actual risk posed by certain environmental hazards. This clinical perspective also highlights the significance of the plaintiff's ability to situate themselves (or not) as appropriately risk averse in the face of known risk; blame and responsibility frame the court's assessment of the plaintiff's claim.

Typically when legal commentators consider the function of risk assessment in litigation their focus tends to be only on actuarial or other scientific calculations of risk. Everyday or commonsense notions of risk have not been 
the focus of academic debate. They are of course harder to pin down, and not as readily drawn upon as scientific calculations of risk to persuade courts on fine points of causation. Certainly many toxic tort suits fail, and other potential actions are thwarted, by a lack of definitive scientific evidence establishing a causal link between the plaintiff's injuries and their exposure to an environmental hazard. The scientific evidence, or at least its 'objectivity', is, Philippopoulos-Mihalopoulos observes, 'a pedestal on which a presumption rests for the comprehension of risk'. ${ }^{71}$ Non-scientific, everyday understandings of risk play a critical role in how the court comprehends the risk to which the plaintiff was exposed and deserve closer analysis. My own experience as a plaintiff's solicitor, ${ }^{72}$ working in the early 1990 s on these kinds of cases, was that despite the requirement to adduce expert evidence, the particulars of any plaintiff's claim are scrutinised by the court through the lens of everyday or commonsense understanding of both the plaintiff's and defendant's conduct in the face of risk. Toxic tort litigation reveals and reports the existence of environmental hazards in a manner which tends to focus on the impact of the toxin on the plaintiff personally, and publicly delineates the harm they have suffered; it allows the articulation of the real, rather than simply theorised or projected, experience and consequence of toxic exposure. ${ }^{73}$

\section{Notes}

1 McMichael, 2001; Worster, 1994.

2 For further analysis on the following points see Goodie, 2008.

3 Rutherford, 1999b: 101-02.

4 Godden and Peel, 2010; Worster, 1994.

5 McMichael, 2001: 21-22.

6 Worster, 1994.

7 Bramwell, 1989: 4; Worster, 1994.

8 Boughey, 1971: 5-6.

9 Wynne, 1992: 114-24.

10 Lee, 2000: 82.

11 Ewald, 1991.

12 Rutherford, 1999b: 116.

13 Foucault, 1976 [1978]; 1991.

14 Dean, 1999; Valverde et al., 2005.

15 World Business Council for Sustainable Development and World Resources Institute 2004 Greenhouse Gas Protocol, accepted by industry as the de facto measure of corporate greenhouse gas emissions.

16 Rutherford, 1999a: 56.

17 Dean, 1999; O’Malley, 1999; Miller and Rose, 1990.

18 Kellow, 1999: 12.

19 Havemann, 2003; Lee, 2000.

20 Lanthier and Olivier, 1999: 75.

21 Kroll-Smith and Westervelt, 2004.

22 Rabin, 1993.

23 Beck, 1999: 22.

24 Havemann, 2003. 
25 O’Malley, 2004.

26 Coyle and Morrow, 2004: 109.

27 Stapelton, 1995: 820.

28 Horwitz, 1982: 211.

29 Fleming, 1992.

30 Ewald, 1991: 201.

31 Ewald, 1991.

32 Lanthier and Olivier, 1999: 75.

33 Toxic tort as a particular form of negligence action emerged only in the late 1970s; it was first recognised by the Association of Trial Lawyers of America as a distinct category of litigation in 1977, Jasanoff, 1995; Kune and Kune, 2003; Rabin, 1993.

34 Jasanoff, 1995: 119.

35 Valverde et al., 2005.

36 E. M. Baldwin \& Son Pty Ltd v Plane and anor.; Jsekarb Pty Ltd v Plane and anor. (1999) Aust. Tort Reports 81-499

37 Steele, 2004: 9.

38 Seltsam Pty Ltd and anor. v McGuiness (2000) 49 NSWLR 262, 277.

39 Seltsam Pty Ltd and anor. v McGuiness (2000) 49 NSWLR 262, 286.

40 Jasanoff, 1995: 59.

41 Edmond and Mercer, 2002: 103.

42 The Daubert case was one of many actions in the US state and federal courts against the manufacturer of the anti-nausea drug Bendectin. The drug had been prescribed for pregnant women to alleviate morning sickness but was later associated with birth defects in the babies of many of those women who had taken the drug.

43 Cranor and Eastmond, 2001: 9.

44 Edmond and Mercer, 2004: 243.

45 Jasanoff, 1995: 65-66.

46 Morrow, 2000.

47 Beck, 1992; Douglas, 1992.

48 For a survey of this commentary see Lupton, 1999; O’Malley, 2004.

49 O’Malley, 2004: 22.

50 Cane, 1997.

51 Morrow, 2000; Rabin, 1993; Toffolon-Weiss and Timmons Roberts, 2004.

52 Ewald, 1991.

53 Douglas, 1992.

54 Lee, 2000: 86.

55 Peel, 2005: 68.

56 Jasanoff, 1995: 125, emphasis added.

57 Chappel v Hart (1998) 156 ALR 517: 562.

58 Douglas, 1992.

59 Maddalena $v$ CSR Ltd and anor. [2004] WASCA 231: ๆ34.

60 Beck, 1999.

61 Douglas, 1992.

62 Lupton, 1993: 428.

63 Cane, 1997: 13.

64 Lee, 2000.

65 McHugh, 1989: 13.

66 Rabin, 1993.

67 Rabin, 1993.

68 Toffolon-Weiss and Timmons Roberts, 2004: 261. 
69 Morrow, 2000.

70 Steele, 2004: 3.

71 Philippopoulos-Mihalopoulos, 2007: 132.

72 For Slater \& Gordon, one of the major Australian law firms specialising in toxic tort litigation.

73 Kroll-Smith and Westervelt, 2004.

\section{Bibliography}

Beck, U., Risk Society: Towards a New Modernity. London: Sage, 1992.

Beck, U., World Risk Society. Cambridge: Polity Press, 1999.

Boughey, A., Fundamental Ecology, Scranton PA: In Text Educational Publishers, 1971.

Bramwell, A., Ecology in the Twentieth Century: A History, New Haven CT: Yale University Press, 1989.

Cane, P., The Anatomy of Tort. Oxford: Hart Publishing, 1997.

Coyle, S. and K. Morrow, The Philosophical Foundations of Environmental Law: Property, Rights and Nature, Oxford: Hart Publishing, 2004.

Cranor, C. and D. Eastmond, 'Scientific ignorance and reliable patterns of evidence in toxic tort causation: is there a need for liability reform?' 64 Law and Contemporary Problems 4, 5-48, 2001.

Dean, M., Governmentality: Power and Rule in Modern Society, London: Sage, 1999.

Douglas, M., Risk and Blame: Essays in Cultural Theory, London: Routledge, 1992.

Edmond, G. and D. Mercer, 'Rebels without a cause? Judges, medical and scientific evidence and the uses of causation', in Causation and Law in Medicine, ed. Freckelton, I. and D. Mendelson, Aldershot: Ashgate Dartmouth, 2002.

Edmond, G. and D. Mercer, 'Daubert and the exclusionary ethos: the convergence of corporate and judicial attitudes towards the admissibility of expert evidence in tort', 26 Litigation. Law and Policy 2, 231-56, 2004.

Ewald, F., 'Insurance and risk', in The Foucault Effect: Studies in Governmentality, ed. Burchell, G., C. Gordon and P. Miller, London: Harvester Wheatsheaf, 1991.

Fleming, J., The Law of Torts, North Ryde NSW: Law Book Company, 9th edn, 1992.

Foucault, M., The History of Sexuality, Vol. 1, Introduction, New York: Pantheon Books, 1976 [1978].

Foucault, M., 'Governmentality', in The Foucault Effect: Studies in Governmentality, ed. Burchell, G., C. Gordon and P. Miller, London, Harvester Wheatsheaf, 1991.

Godden, L. and J. Peel, Environmental Law: Scientific, Policy and Regulatory Dimensions, Melbourne VIC: Oxford University Press, 2010.

Goodie, J., 'Toxic tort and the articulation of environmental risk', 12 Law Text and Culture, 69-102, 2008.

Havemann, P., 'Genetic modification, ecological good governance and the law: New Zealand in the Age of Risk', 10 James Cook University Law Review, 7-50, 2003.

Horwitz, M., 'The doctrine of objective causation', in The Politics of Law: A Progressive Critique, ed. Kairys, D., New York: Pantheon, 1982.

Jackson, P., 'Passive smoking and ill health: practice and process in the production of medical knowledge', 16 Sociology of Health and Illness 4, 423-47, 1994.

Jasanoff, S., Science at the Bar: Law, Science and Technology in America, Cambridge MA: Harvard University Press, 1995. 
Kellow, A., International Toxic Risk Management: Ideals, Interests and Implementation, Cambridge: Cambridge University Press, 1999.

Kroll-Smith, S. and S. Westervelt, 'People, bodies and biospheres: nexus and the toxic tort', 26 Law and Policy 2, 177-86, 2004.

Kune, R. and G. Kune, 'Proof of cancer causation and expert evidence: bringing science to the law and the law to science', 11 Journal of Law and Medicine, 112-21, 2003.

Lanthier, I. and L. Olivier, "The construction of environmental "awareness", trans. M. Eloy, in Discourses of the Environment, ed. Darier, E., Oxford: Blackwell, 1999.

Lee, R., 'From the individual to the environmental: tort law in turbulence', in Environmental Protection and the Common Law, ed. Lowry, J. and R. Edmunds, Oxford: Hart Publishing, 2000.

Lupton, D., 'Risk as moral danger: the social and political functions of risk disclosure in public health', 23 International Journal of Health Sciences, 3, 425-35, 1993.

Lupton, D., Risk, London: Routledge, 1999.

McHugh, M., 'Neighbourhood, proximity and reliance', in Essays on Damages, ed. Finn, P., Sydney NSW: Law Book Company, 1989.

McMichael, A., Human Frontiers, Environments and Disease: Past Patterns, Uncertain Futures. Cambridge: Cambridge University Press, 2001.

Miller, P., and N. Rose, 'Governing economic life', 19 Economy and Society 1, 1-31, 1990.

Morrow, K., 'Nuisance and environmental protection', in Environmental Protection and the Common Law, ed. Lowry, J. and R. Edmunds, Oxford: Hart Publishing, 2000.

O'Malley, P., 'Governmentality and the risk society', 28 Economy and Society 1, 138-48, 1999.

O'Malley, P., Risk, Uncertainty and Government, London: Glasshouse Press, 2004.

Peel, J., The Precautionary Principle in Practice: Environmental Decision-making and Scientific Uncertainty, Sydney NSW: Federation Press, 2005.

Philippopoulos-Mihalopoulos, A., Absent Environments: Theorising Environmental Law and the City, London: Routledge, 2007.

Rabin, R., 'Institutional and historical perspectives on tobacco tort liability', in Smoking Policy: Law, Politics and Culture, ed. Rabin, R. and S. Sugarman, New York: Harper Torchbooks, 1993.

Rutherford, P., 'The entry of life in to history', in Discourses of the Environment, ed. Darier, E., Oxford: Blackwell, 1999a.

Rutherford, P., 'Ecological modernization and environmental risk', in Discourses of the Environment, ed. Darier, E., Oxford: Blackwell, 1999b.

Stapelton, J., 'Tort, insurance and ideology', 58 Modern Law Review, 820-45, 1995.

Steele, J., Risks and Legal Theory, Oxford: Hart Publishing, 2004.

Toffolon-Weiss, M. and J. Timmons Roberts, 'Toxic torts, public interest law, and environmental justice: evidence from Louisiana', 26 Law and Policy 2, 259-87, 2004.

Valverde, M., R. Levi and D. Moore, 'Legal knowledges of risk', in Law and Risk, Law Commission of Canada, Vancouver BC: UBC Press, 2005.

Weir, L., 'Recent developments in the governance of pregnancy', 25 Economy and Society 3, 372-92, 1996.

Worster, D., Nature's Economy: A History of Ecological Ideas, Cambridge: Cambridge University Press, 2nd edn, 1994.

Wynne, B., 'Uncertainty and environmental learning: reconceiving science and policy in the preventative paradigm', 2 Global Environmental Challenge, 111-27, 1992. 
82 Law and ecology

\section{Cases}

E. M. Baldwin \& Son Pty Ltd v Plane and anor; Jsekarb Pty Ltd v Plane and anor. (1999) Aust Tort Reports 9 81-499.

Chappel v Hart (1998) 156 ALR 517.

Daubert v Merrell Dow Pharmaceuticals Inc 509 US 579, 113 SCt 2786, 125 LEd2d 469 (1993).

Maddalena v CSR Ltd and anor. [2004] WASCA 231.

Seltsam Pty Ltd and anor. v McGuiness (2000) 49 NSWLR 262. 


\section{The precautionary principle}

\section{Practical reason, regulatory decision-making and judicial review in the context of functional differentiation}

\section{John Paterson}

\section{I Introduction}

When it was proposed to incorporate the precautionary principle into the French constitution as part of an environmental charter, the reaction of the scientific establishment in France was radically against it. The Academy of Science and the Academy of Medicine called on the government 'to avoid including the PP in a constitutional text because of the potential catastrophic consequences for scientific development, technological innovation, public health, economic welfare and even environmental protection'. ${ }^{1}$ Such reactions, however, have not prevented its incorporation in a growing range of legal instruments impacting upon environmental law and public health, from international treaties, through national constitutions (including the French) to domestic legislation and regulation. The long-standing conceptual debate about the principle has accordingly more recently been supplemented by discussion of its implementation to produce a series of related questions about its nature and practicability:

- Is the precautionary principle scientific (as opposed, for example, to ideological)?

- If so, can it be made operational in policy and regulatory settings?

- If so, can its implementation be subjected to meaningful judicial review?

- If not, does that call the practical usefulness of the principle into question?

This chapter considers these questions, reviews the competing answers that have been suggested and concludes by defending a stronger role for the courts in reviewing precautionary decision-making than has heretofore been evident in many jurisdictions.

In section 5.2 a positive answer to the question of whether the precautionary principle is scientific is ultimately offered, drawing on the work of David Resnik in the field of the philosophy of science. ${ }^{2}$ The question of the operability of the principle in practical policy and regulatory contexts is then considered in section 5.3 on the basis of one of the key disputes between the 
WTO and the EU. While this demonstrates that there can be strongly contested understandings of the principle in the absence of sufficiently clear definitions in key legal texts, a systems theory reading of the situation cautions against any too simplistic idea that a clearer definition would resolve such problems. While the precise approach to the implementation of the precautionary principle proposed by Resnik would undoubtedly assist in the making of precautionary decisions, the inevitable presence of functionally differentiated social systems in such contexts ensures that a unique and indisputable answer remains out of reach. A reflexive reading of Resnik's approach is accordingly offered as an indication of the limits of what may be hoped for in situations where a decision under ignorance (that is, where it is impossible to assign probabilities to different choices) must be made. This reflexive reading then offers a potential answer to the question raised by Elizabeth Fisher and Ronnie Harding with respect to the appropriate model of administrative constitutionalism that should underpin the implementation of the precautionary principle. ${ }^{3}$ This is important in considering the extent to which the precautionary principle is justiciable, which is considered in section 5.4. Drawing on an analysis of one of the key statements on the principle by the European courts, the difficulties that have beset judicial review of precautionary decision-making are highlighted, while at the same time the potential for the courts to engage in meaningful review is pointed out. The conclusion drawn in section 5.5 is that, while there would rightly be concern about any shift away from the currently deferential attitude of the courts in many jurisdictions when it comes to the review of precautionary decisions by the executive, there is actually much to welcome where such a shift takes place within the context of the adoption of a suitably sophisticated approach to the implementation of the principle, both by the executive and by the courts. What is offered is by no means a magic bullet, but it does have the potential to ensure that, in the context of functional differentiation, all concerned keep in view the fragmented nature of the problems that precautionary decisions are required to respond to as well as the dangers inherent in assuming that there are simple unitary answers.

\subsection{Is the precautionary principle scientific?}

In the context of environmental law the precautionary principle needs to be understood as a component of the overarching concept of sustainable development. The key definition of this concept is to be found in Agenda 21, the preamble to which describes the document as setting out a dynamic programme that 'marks the beginning of a new global partnership for sustainable development'. ${ }^{4}$ The preamble further states that the implementation of this programme is to be carried out 'in full respect of all the principles contained in the Rio Declaration on Environment and Development ${ }^{5}$ and it is among those principles that the precautionary principle is to be found. 
The precautionary principle has been defined in a variety of different ways in a variety of different domestic and international political and legal settings since its first appearance as the 'foresight principle' in Germany in the 1970s, ${ }^{6}$ but the Rio Declaration formulation is the one most often referred to. There it is provided that:

In order to protect the environment, the precautionary approach shall be widely applied by States according to their capabilities. Where there are threats of serious or irreversible damage, lack of full scientific certainty shall not be used as a reason for postponing cost-effective measures to prevent environmental degradation. ${ }^{7}$

The apparent common sense of the basic idea contained in that definition can make the controversy that surrounds the precautionary principle difficult to understand. But the controversy is no less real for all that. The various criticisms directed at the principle have been grouped under five headings by a team at the Royal Institute of Technology in Stockholm. Their review of the literature reveals that the critics are concerned that the principle (1) is illdefined, (2) is absolutist, (3) leads to increased risk-taking, (4) is a value judgement or an ideology, and (5) is unscientific or marginalises the role of science. ${ }^{8}$ It would be possible to consider each of these criticisms individually, but it is suggested here that the first four may be read as specific examples of the fifth. For example, for a statement to be scientific it must be falsifiable. It must, therefore, be sufficiently clearly defined to allow meaningful testing and must by definition be a provisional statement rather than an absolute one. ${ }^{9}$ By the same token, for a statement to be scientific it cannot be a value judgement or based on an ideology unless it also happens to be falsifiable, which might in turn lead to questions about its status as a statement of values or ideology. As regards the criticism of increased risktaking, it will be contended here that a properly scientific understanding of the precautionary principle aims specifically at the reduction of risk at a point when meaningful statements about risk are impossible. It is further suggested, therefore, that a successful response to the criticism that the precautionary principle is unscientific would also represent a successful response to the other criticisms.

Were the 'unscientific' criticism to be shown to be well founded, the precautionary principle would face a very serious problem, which would in turn impact upon sustainable development and indeed environmental law more broadly. Agenda 21 states that science should 'provide information to better enable formulation and selection of environment and development policies in the decision-making process'. ${ }^{10}$ Furthermore, the key role for science is emphasised by the fact that Agenda 21 identifies a series of support programmes: strengthening the scientific basis for sustainable management; enhancing scientific understanding; improving long-term scientific assessment; building up 
scientific capacity and capability. ${ }^{11}$ However, the very fact that the need for these programmes is felt appears to be an admission that science is unable to answer all the questions that sustainable development asks, and it is precisely here that the precautionary principle makes its appearance in Agenda 21:

In the face of threats of irreversible environmental damage, lack of full scientific understanding should not be an excuse for postponing actions which are justified in their own right. The precautionary approach could provide a basis for policies relating to complex systems that are not yet fully understood and whose consequences of disturbances cannot yet be predicted. ${ }^{12}$

Taking all this together, the criticism that the precautionary principle is unscientific is surely not without foundation: Agenda 21 appears to admit that when science is unable to provide an answer, something other than science may be required and that specifically is the precautionary principle. This certainly looks worrying for the principle's proponents, but perhaps the charge of being unscientific is less damaging than has been assumed so far. Might it ultimately amount to no more than a fairly neutral observation? It is submitted, however, that if that is what was intended then the term used would be 'non-scientific'. The critics of the precautionary principle definitely have something else in mind: when applying the term unscientific they seek to convey the message that the precautionary principle is in essence irrational in the sense that it does not allow logical arguments or sound judgements to be made. ${ }^{13}$ If that criticism can be substantiated, it would have very serious implications for decision-making processes that claim to make use of the principle in reaching conclusions about whether, for example, technologies may be developed and deployed and, if so, to what extent. A decision on the basis of the precautionary principle could be taken for the best of motives, but if the principle itself is fundamentally flawed in the way implied by this criticism, then the decision could nevertheless be sub-optimal and perhaps even counterproductive.

There is, then, clearly a pressing need for more clarity on the nature of the precautionary principle to determine whether or not it offers a basis for rational decision-making. In this regard, the work of David Resnik from the field of the philosophy of science is instructive in so far as its starting point is the precise question with which this section of the chapter is concerned: is the precautionary principle unscientific? ${ }^{14}$ The sting of the criticism is already drawn to some extent when Resnik points out that what may properly be described as 'scientific' is controversial even within the philosophy of science itself. Furthermore, he helps to focus and delimit the criticism by pointing out that much will depend upon what society seeks to achieve by utilising the precautionary principle. With these points in mind, Resnik reformulates the basic question so that it reads: is the precautionary principle a rational 
method for making practical decisions? ${ }^{15}$ What Resnik is aiming to do, therefore, is to see whether the precautionary principle properly belongs within the boundaries drawn by the requirements of practical reason. To do that, he distinguishes three types of decision-making situations:

- Decisions under certainty, where the outcomes of different choices are known.

- Decisions under risk, where even though the outcomes of different choices are not known with certainty it is nevertheless the case that probabilities can be assigned to the outcomes of different choices.

- Decisions under ignorance, where it is not even possible to assign probabilities to the outcomes of different choices. ${ }^{16}$

The first situation raises few difficulties and could be said to describe the making of fully informed decisions. The second situation is more complex, but can be dealt with using recognised decision-making approaches, for example, those involving quantitative risk assessment (QRA). Decisions under risk will often be controversial: parties may disagree about which values to input into QRA calculations, about the adequacy of the data set, about the degree of conservatism that is appropriate, and so on. Nevertheless, the very fact that a decision-making technique such as QRA can be employed allows the point of disagreement to be identified relatively easily. A focus for discussion thus exists, around which the strengths and weaknesses of competing arguments can be tested. Furthermore, the very fact that probabilities can be assigned and that techniques such as quantified risk assessment can be utilised means that decisions under risk do not require the application of the precautionary principle. One of the key messages articulated by Resnik, therefore, is precisely that the principle is only applicable to decisions under ignorance.

It is immediately clear, however, that if decisions under risk may be controversial, the situation is likely to be even more difficult for decisions under ignorance. Indeed, if it is not even possible to assign probabilities to the outcomes of different choices, then there is apparently no reason not to assign an equal probability to the best-case and the worst-case scenarios. If that is true, then logically there would appear never to be a reason to discount the worst-case scenario and thus never a reason not to opt for the most precautionary approach. Critics of the precautionary principle such as Charnley accordingly contend that it operates in effect as the principle of inaction. ${ }^{17}$ Defenders of the principle such as Peterson point out, however, that operating the principle in this way is actually to replace it with the principle of insufficient reason. ${ }^{18}$ In so far as Peterson is correct, criticism of the precautionary principle as the principle of inaction is surely wide of the mark and may itself be said to be 'irrational'. ${ }^{19}$

While these problems with the precautionary principle can be discounted as more apparent than real, there is, however, a more fundamental problem 
for Resnik in the form of the criticism levelled by Majone against the precautionary principle, namely that it relies upon an illegitimate distinction between risk and ignorance. For Majone, there is no such clear-cut division, but rather only a knowledge-ignorance continuum. ${ }^{20}$ This may be countered, however, by suggesting that Resnik's tripartite scheme translates into three points on that continuum. ${ }^{21} \mathrm{~A}$ stronger defence is paradoxically provided by Majone himself when he concedes that the precautionary principle does have a limited role, namely where 'losses (or utilities) are unbounded' and where it is 'clearly impossible to calculate expected values', for example, where there is a threat of 'serious and irreversible damage'. ${ }^{22}$ It can accordingly be contended that Majone and Resnik are actually in agreement as to the situations when it is appropriate to resort to the precautionary principle: the boundaries set by Majone coincide with Resnik's definition of decisions under ignorance. Support for this interpretation may be drawn from an analogous situation in tort law characterised by the impossibility of assigning probabilities to one or another causation scenario and where no remedy would available to the plaintiff notwithstanding that a duty of care has been breached and harm has been suffered. Courts in such situations have found it appropriate to deviate from the standard 'but for' and balance of probabilities tests to establish causation and ensure that a remedy is available. ${ }^{23}$ It may be suggested, accordingly, that the precautionary principle is the ex ante analogue of the carefully defined exception that the courts have set down for dealing with harm ex post in situations where it is impossible to assign probabilities. ${ }^{24}$

So far, however, there is reassurance only that contexts exist in which there is a need for an approach to decision-making which can cope with the inability to assign probabilities. There is as yet no clear answer to the question whether such approaches may correctly be described as scientific - courts in the sort of indeterminate causation cases just referred to have indeed been at pains to deny that the decisions they are taking are based on scientific or philosophical as opposed to strictly legal understandings of causation. In order to answer that question it is necessary next to consider how the precautionary principle may be operationalised. Here again, Resnik offers assistance. In brief he sees the operationalisation of the precautionary principle as involving two stages. Firstly, in a given decision-under-ignorance situation it is necessary to consider whether a hypothetical threat is plausible. This is a question that scientists are well placed to answer in as much as they are used to considering whether a given hypothesis is plausible prior to committing limited resources to testing it. Well-established criteria for a test of plausibility are accordingly available within science including: coherence, explanatory power, analogy, precedence, precision, and simplicity. ${ }^{25}$ In so far as a hypothetical threat meets these criteria it may be deemed to be plausible. It will also be possible to differentiate between different hypothetical threats as more or less plausible utilising these criteria and it is therefore possible to demonstrate that there really is no equivalence with the principle of insufficient reason. 
The second stage of Resnik's approach to the implementation of the precautionary principle is to consider whether, in so far as a hypothetical threat is deemed to be plausible, any proposed response is reasonable. Once again, there are well established criteria for addressing such a question (notably within law), including: effectiveness, proportionality, realism, efficiency, consistency and non-discrimination (and it is interesting to note that Resnik here draws inspiration from the European Commission's Communication on the Precautionary Principle). ${ }^{26}$ Thus, in so far as a proposed response to a plausible hypothetical threat meets these criteria, then it may be deemed to be reasonable. It will also be possible to differentiate between proposed responses as more or less reasonable utilising these criteria and it is therefore possible to see that there really is no equivalence with the principle of inaction.

Taken in the round, then, the conclusion to be reached on the question of whether the precautionary principle is scientific is that it is, in so far as this is understood in a sufficiently sophisticated way to cope with the complexity of decision-under-ignorance situations. In other words, there needs to be an acknowledgement of what is distinctive about situations in which it is not possible to assign probabilities to different choices, a recognition that quantified risk assessment techniques have no traction in such contexts, and an acceptance that it is nevertheless possible to take decisions in a way consistent with the requirements of practical reason on the basis of tests that are well established both within science and within law.

\subsection{Can the precautionary principle be made operational in policy and regulatory settings?}

So much for the operationalisation of the precautionary principle as a means of reaching rational decisions in theory, but is there any evidence that this approach is being adopted in practice by policy and regulatory actors? In this regard, the example of the differential approaches to the precautionary principle taken by the WTO and the European Commission with regard to the Agreement on the Application of Sanitary and Phytosanitary Measures is instructive. Article 5(7) of the SPS Agreement provides that:

In cases where relevant scientific evidence is insufficient, a Member may provisionally adopt sanitary or phytosanitary measures on the basis of available pertinent information, including that from the relevant international organizations as well as from sanitary or phytosanitary measures applied by other Members. In such circumstances, Members shall seek to obtain the additional information necessary for a more objective assessment of risk and review the sanitary or phytosanitary measure accordingly within a reasonable period of time. 
The European Commission's interpretation of this measure reads:

The [sanitary or phytosanitary] measures, although provisional, shall be maintained as long as the scientific data remain incomplete, imprecise or inconclusive and as long as the risk is considered too high to be imposed on society. ${ }^{27}$

Majone has described this approach as establishing an extremely subjective standard that relaxes 'all the substantive and procedural constraints on regulatory arbitrariness ... to the point of being non-binding, ${ }^{28}$ And he has criticised the Commission for essentially utilising the precautionary principle to disguise political reasons for adopting and maintaining such measures, specifically pressure from the European Parliament, which is in turn responding to general public unease with regard to globalisation and new technologies such as GMOs. ${ }^{29}$

Considering this dispute, it is possible to discern more clearly some of the contentious issues surrounding the precautionary principle. Firstly, is it unreasonable for a public administration to seek to be responsive to public concern? The Commission has after all, just as often been criticised for being remote and unresponsive. ${ }^{30}$ On the other hand, there are certainly times when public administrations push ahead with policies on the basis that public opinion has essentially reached the 'wrong' decision: the UK government's insistence on the MMR vaccine despite a concerted campaign against it and widespread media and public concern may be cited as a classic example of this situation. ${ }^{31}$ Secondly, is either of the interpretations of the precautionary principle in this case more open to subjectivity than the other? The key difference between them lies in the emphasised portions of the following phrases:

[World Trade Organisation] Members shall seek to obtain the additional information necessary for a more objective assessment of risk and review the sanitary or phytosanitary measure accordingly within a reasonable period of time.

[European Commission] Measures, although provisional, shall be maintained as long as the scientific data remain incomplete ... and as long as the risk is considered too high.

It may accordingly be suggested that opting for one or other of these versions reveals a subjective preference for a more business-oriented approach to precaution in the case of the WTO's language and a more social welfareoriented approach in the case of the European Commission's. A more sophisticated analysis may be provided by systems theory. From that perspective, the approaches taken by the WTO and by the European Commission may be differentiated on the basis that they reveal the operation of different 
communicative social systems. ${ }^{32}$ The first approach may thus be read as a deployment of the code of the economic system (payment/non-payment) and more specifically of a steering programme focused on minimising the deferral of payments. ${ }^{33}$ Similarly, the second approach may be read as a deployment of the code of the system of science (true/false) and more specifically of a steering programme focused on minimising risk. ${ }^{34} \mathrm{As}$ if the distance between these two constructions of the precautionary approach in the context of the SPS Agreement were not already great enough, a systems theory reading of the situation would go on to point out that the system of politics will in turn reconstruct these selections on the basis of its own power code. There is accordingly from a systems perspective apparently no objective solution, as it were, to the problem raised by the different systemic constructions of the precautionary principle that are possible in a given practical setting.

The question is, then, whether Resnik's two tests of plausibility and reasonableness would do anything to assist in this sort of situation. It is first of all necessary to be clear that they do not constitute a mechanism by which a single agreed decision will automatically be reached. It would accordingly be possible to reach either the WTO's or the Commission's conclusion by applying the plausibility and reasonableness tests. In so far as that is the case, it might be objected that this approach adds nothing to an already complex situation and thus should be discounted. It is suggested, however, that any understanding of the precautionary principle in terms of 'brightline standards' is inappropriate, as Fisher and Harding have stressed. ${ }^{35}$ An approach such as Resnik's provides a means of reaching decisions under ignorance within the realms of practical reason on the basis of familiar, well established and accepted standards. While it will not, therefore, generate unique answers, it will encourage transparency and accountability in the making of decisions under ignorance and will in any event reveal the exact location and nature of disagreements in so far as public actors would need to address explicitly the various criteria of the plausibility and reasonableness tests.

From a systems theory perspective, this finding is not at all surprising or disappointing. The theory that is based on the concept of cognitively open but normatively closed systems is by no means taken aback by the conclusion that scientific, economic, political and, for that matter, legal constructions of the same issue are incommensurable and that information cannot be transferred unproblematically between these systems. Some versions of systems theory would continue that analysis to the point where the idea that Resnik's tests could have any hope of contributing to the resolution of disputes about the implementation of the precautionary principle would have to be abandoned. ${ }^{36}$ Other readings of systems theory would, however, perceive in those tests a reflexive potential - in other words, the possibility that the content and application of those tests could constitute an opportunity for structural coupling between the systems in play in a given practical setting. ${ }^{37}$ There would still be no unique conclusion, there would still remain the potential 
for even radically different constructions of the same issue within different systems, but the existence of the tests and the requirement to utilise them would mean that the systems in play would be required to perform simultaneous transformations (even if only momentarily) on the basis of the same extraneous event, which in systems terms is already to say a great deal. This in turn would mean that the systems in play would need to deal with the fact of alternative constructions rather than ignoring them. Again, there is no suggestion here of anything akin to an ideal speech situation, no hope is held out of an intersubjective bridge being built between competing constructions by the simple expedient of the application of the tests of plausibility and reasonableness. ${ }^{38}$ But what is offered, consistent with a systems theory perspective, is the possibility that the application of these tests represents an example of structural coupling and thus the possibility that some selections may become more difficult to make than others. In other words, while even this version of the theory does not imply that systems can observe what they cannot observe, it does allow that the unobservability is observable - what Philippopoulos-Mihalopoulos has referred to as presence in absence. ${ }^{39}$

Before becoming too starry-eyed about this reflexive reading of Resnik's approach, however, it is necessary to be sure that it properly addresses observations made by Fisher and Harding about the implementation of the precautionary principle, specifically the fact that despite considerable development of frameworks to implement it in a range of jurisdictions, little if any thought has been given to the relationship between those frameworks and the underlying theory of administrative constitutionalism. ${ }^{40}$ This is important, they contend, because without clarity in this regard there is a risk that the precautionary principle becomes meaningless. ${ }^{41}$ In considering this issue, Fisher and Harding identify two principal models of administrative constitutionalism, namely the deliberative-constitutive (DC) (which they draw from the earlier work of Deville and Harding) $)^{42}$ and the rational-instrumental (RI) (which they draw from the European Commission's Communication on the Precautionary Principle). ${ }^{43}$ They then check to see, firstly, how each model approaches the sorts of issues raised by the implementation of the precautionary principle and, secondly, whether an understanding of the precautionary principle favours one model of administrative constitutionalism over the other. Given the foregoing discussion it would be particularly instructive to discover whether the reflexive reading of Resnik's two-test approach to the implementation of the precautionary principle favours one model over the other and whether the conclusion mirrors that of Fisher and Harding.

Beginning with the role and nature of the public administration as conceived by each of the two models, the DC model sees an institution constituted with broad deliberative powers that can be adapted to the problem at hand' whereas the RI model sees an 'instrument of [the] legislature that carries out a limited set of tasks on the basis of a rational methodology'. The DC model 
accordingly appears more in tune with modern ideas of stakeholder engagement in the policy and regulatory process, whereas the RI model appears closer to a classical top-down technocratic approach. That is not to say that public participation has no role in the RI model, but whereas in the DC model this is vital to the achievement of a 'deliberative problem-solving process', in the RI model it is rather a matter of aiding accountability and a 'means of identifying preferences'. This difference is reflected in the way in which the two models characterise the problems they seek to regulate. Whereas the DC model understands these to be complex both sociopolitically and physically, the RI model is convinced that they are 'manageable by methodologies'. The same difference informs the way in which the two models understand the nature of the administrative process, with the DC model seeing it as combining 'scientific analysis and deliberation' while the RI model sees a clear 'division between scientific and political processes'. As regards the basis for the justification of decisions under both models, the DC model sees this as constituted both by the giving of reasons and by the fact of deliberation whereas for the RI model this depends upon a demonstration of the fact that the 'decision-maker adhered to predetermined methodologies and standards'. The range of differences that exist between the two models accordingly reflects overall the different motivations for their development. In the case of the DC model, the motivation is the desire to demonstrate 'how the principle can be implemented in any institutional setting' whereas for the RI model the motivation is the desire to demonstrate that 'action pursuant to the principle is accountable and consistent with pre-existing legal obligations' ${ }^{44}$

Fisher and Harding conclude from this comparison of the two models that while the DC model looks at first sight to be the best-suited to the implementation of the precautionary principle, the matter is not necessarily so straightforward and it may be a matter of seeing which approach is best suited to specific circumstances. ${ }^{45}$ They note also that the choice of one or other model in the real world has reflected the preferences of those making the choice. Thus, policy makers have tended to favour the deliberative-constitutive model whereas lawyers have tended to favour the rational-instrumental model. ${ }^{46}$ The reason for the lawyers' choice is surely related to the greater ease with which the RI model (at least as it is more narrowly understood) would be amenable to judicial review.

What happens, however, when the two models are considered in terms of the reflexive reading of Resnik's two-test approach to the implementation of the precautionary principle? Understanding the contention that exists in precautionary decision contexts in systems terms certainly appears to favour the DC over the RI model. There is an acceptance that the issues at stake may be constructed very differently within different systems and that a single, uniform and somehow unquestionably 'rational' answer will only mask rather than resolve the problem. It must be stressed, however, that the systems 
approach moderates the enthusiasm with which the DC model might be embraced, in so far as it highlights the limits that inevitably exist with regard to the achievement of simple, unitary answers to complex precautionary questions. The two-part test understood reflexively provides an opportunity for structural coupling, but it does not hold out any much stronger hope than that. Does all this mean that the RI model is entirely discounted by the reflexive reading of Resnik's two-part test? The answer is a qualified no. That approach could operate under either model but it is important to note that this conclusion only holds good in so far as key aspects of the rationalinstrumental model are understood in a particular way. Specifically, this requires that the rational-instrumental model's focus on adherence to methodology is understood in the broader way that the reflexive reading of the plausibility and reasonableness tests imply and not in a narrowly technocratic way. In so far as the tests were to be understood in such a way, then the systems approach clearly shows that this would be to produce an unacceptably restricted view of the complexity of the problem at hand - one which ignores the presence of other systems in play and of the distinctive constructions of the issues and indeed of the two-part tests that they bring to the situation.

Taken in the round, then, the answer to the question of whether the precautionary principle can be made operational in policy and regulatory settings is once again a qualified yes. Resnik's two-part test offers a practicable approach based on established standards from science and law that nevertheless avoids any misunderstanding that the principle can be expressed as an algorithm. Practical examples, however, reveal the extent to which the implementation of the principle takes place within highly contested settings which in turn reveal that the application of the tests of plausibility and reasonableness will themselves become fractured. Taking a systems view of the situation renders this finding less surprising and in turn offers a possible escape route, albeit one that accepts fracture as inevitable (even necessary) and thus understands the application of the tests in a particular, and specifically reflexive, way. This reading sees the two tests as an opportunity for structural coupling between the systems in play, which nevertheless does not imply the emergence of an intersubjective dialogue nor of an objective resolution. At best, structural coupling encourages a mutual reading of the different constructions, which may appear to be thin gruel to those with higher hopes for the precautionary principle, but which nevertheless may strike a more realistic note with those who have had experience of such situations in practice. Fisher and Harding, however, are surely right to insist that there needs to be greater reflection as to the model of administrative constitutionalism within which the implementation of the precautionary principle takes place. In this regard, the reflexive reading of the two-part test appears to favour the DC model (while insisting on the limitations of normative closure and the extent of what is possible from structural coupling) and would require a particular 
understanding of the RI model, which would either see the narrow view as an example of a purely technocratic construction of the problem and the solution or would call for a broader view which understands that a range of system rationalities are in play. The question that remains, however, is whether any implementation of the precautionary principle could be subjected to meaningful judicial review. It would surely seem to be the case that, if it could not, then the efficacy of the principle would be called into question. It would be one thing to claim that the application of the two-test approach is a rational basis for decision-making under ignorance (understood specifically as the inability to assign probabilities to different choices), but it would be quite another to admit that the application of the tests was itself beyond the reach of judicial review. In such circumstances, what reassurance would there be that the decision-making process had not been hijacked by vested interests whether state or commercial in nature? ${ }^{47}$ What reassurance would there then be that precautionary decisions were indeed imbued with the characteristics of practical reason?

The points made by Fisher and Harding in relation to existing choices as to the models of administrative constitutionalism already raise interesting and potentially troubling further questions in this regard. Does the lawyers' preference for the RI model indicate that only this one is amenable to review and thus that the DC model is not? On the other hand, do the concerns highlighted about the narrowness of the traditional understanding of the RI model indicate that while it may be amenable to judicial review it does not necessarily allow an adequate implementation of the precautionary principle? And beyond these questions, what happens to the prospects for judicial review, firstly, when it is recognised that what is required for a rational implementation of the precautionary principle is something akin to Resnik's two-test approach and, secondly, when more specifically it is recognised that the most realistic reading of those tests in any practical setting is the reflexive one which acknowledges the insights of a systems theory understanding of the complexity of decision-under-ignorance situations?

\subsection{Can the implementation of the precautionary principle be subjected to meaningful judicial review?}

Before a firm conclusion can be reached in this regard, it will be instructive to look at the experience of courts in reviewing precautionary decisions. The courts in the UK are of course well aware of the limits of judicial review and of the questions of technical competence and constitutional propriety that arise should they seek to become too substantively involved in what is properly and reasonably the preserve of the executive. It is thus not surprising to find that the evidence from the UK suggests a very cautious approach on the part of the courts in so far as the precautionary principle is concerned. Fisher concludes her survey of the UK case law by stating that (1) 'while 
many actions are found to be in accordance with the precautionary principle there has been no development of a principled framework for deciding what is precautionary' and (2) 'review tends to be deferential and thus effectively sanctioning the status quo' ${ }^{48}$ On the basis of this assessment of the UK approach, there would appear to be problems in practice associated with making the precautionary principle justiciable.

While a deferential attitude on the part of the UK courts might not be surprising, the Nordic courts might be expected to have a more advanced approach to the precautionary principle, given the fact that these jurisdictions have been at the forefront of the development of environmental law generally. In fact, this turns out not to be the case and surveys of the case law reveal a similarly deferential approach. Studies of the situation in Denmark ${ }^{49}$ and in Finland ${ }^{50}$ both find that judges understand the principle to be more political than legal, with the result that precautionary decisions will not be substantively reviewed. Judicial restraint in Norway meanwhile appears to be due to the fact that the precautionary principle is hardly evident in environmental policy areas and Bugge questions whether it will continue to evolve from an optional into a compulsory principle. ${ }^{51}$ While Sweden has enshrined the principle in its Environmental Code, the position of the judiciary is complicated by the fact that, as Michanek reports, a balancing of interests is allowed that may result in a diminution in its impact. ${ }^{52}$ The evidence from Scandinavia accordingly appears to mirror that from the UK. Judicial restraint is the order of the day on the basis that precautionary decisions are properly for the executive and therefore provided that procedural requirements have been met there will rightly be no substantive second-guessing of the decision-maker.

There is of course a much more extensive jurisprudence on the precautionary principle at the level of the European Court of Justice and the Court of First Instance, but it may not ultimately take us much further in obtaining clarity about the scope for judicial review. Scott and Vos suggest that these courts have also interpreted the principle so as to allow member states considerable discretion to err on the side of caution so long as they provide evidence of scientific uncertainty. ${ }^{53}$ Fisher suggests that the problem with the approach of the ECJ and CFI can be traced back to the fact that the European approach to the precautionary principle represents the paradigm case of the rational-instrumental model of administrative constitutionalism. Furthermore, it appears that this has been narrowly understood in the Commission's Communication on the Precautionary Principle, with the result that it has problematically required decision-makers to engage in risk assessments which, as Resnik's tripartite scheme revealed, are simply inappropriate to decisions under ignorance where it is impossible to assign probabilities. Fisher describes this as a requirement that decision-makers proceed on a factual basis when facts are precisely what are missing. Her reading of the ECJ and CFI jurisprudence suggests that it reflects this tension without 
recognising it. ${ }^{54}$ In other words, there is a failure to appreciate what is distinctive about decisions under ignorance as opposed to decisions under risk.

There would accordingly appear to be two principal obstacles in the way of achieving the meaningful judicial review of precautionary decisions: firstly, the question of whether judges are clear as to which requirements would need to be met in implementing the principle in order to be able to ensure the procedural adequacy of precautionary decisions while maintaining a respectful distance from any trespass on the substantive aspect; secondly, the question of whether judges are clear as to the difference between decisions under risk and decisions under ignorance in order that they may not place unreasonable demands on decision-makers to proceed on a factual basis when it is precisely the absence of the ability to assign probabilities that characterises the sorts of situations in which the precautionary principle is appropriately applied. From the perspective of systems theory (at least the variant that has been outlined above) the justiciability of the precautionary principle is crucial in so far as it is the means by which the fragmented problems that engage the principle can be internalised within the legal system. From the point of view of society within that theory, law's ability to internalise these problems, both at the regulatory and especially at the judicial level, allows normative expectations to be stabilised even in the context of significant uncertainties.

In order to see more clearly what this means in practice, it is instructive to look more closely at one of the key statements on the precautionary principle by the Court of First Instance, namely the case of Pfizer Animal Health SA v Council. ${ }^{55}$ In Pfizer the issue at stake was whether the Community institutions had erred in removing a particular substance from a list of authorised growth promoters for use in agricultural animals on the grounds that it could give rise to antibiotic resistance that could be passed to humans. Article 11 (3) of Directive 70/524 allowed the Commission to commence a procedure to alter the list of authorised antibiotics where this was considered necessary to ensure the protection of human or animal health or the environment following the adoption of a safeguard measure by a member state. The Commission took such action on the basis of the precautionary principle in relation to the antibiotic virginiamycin produced by Pfizer in response to a safeguard measure adopted by Denmark, which ultimately resulted in Council Regulation (EC) 2821/98 removing that antibiotic from the authorised list. Pfizer applied to the Court of First Instance for annulment of the regulation. The judgment in this case is long and complex, and what follows, therefore, concentrates in particular on the court's treatment of the precautionary principle.

The parties to the case were in agreement that at the time when the regulation removing virginiamycin was adopted 'neither the reality nor the seriousness of the risk' of the transfer of antibiotic (specifically streptogramin) resistance from animals to humans 'had been scientifically proven'. ${ }^{56}$ It can immediately be seen, therefore, that this was properly a situation in which the 
precautionary principle would have a role. Pfizer, while conceding that the Community institutions were entitled to take preventive measures of the sort involved in this case, nevertheless contended that they 'did not correctly assess [the] risk' and 'that they adopted a decision for reasons of political expediency without a proper scientific basis' ${ }^{57}$ - thus echoing the sort of critique of the precautionary principle made by Majone discussed above.

In considering this complaint, the CFI begins by noting that both it and the ECJ have held that "where there is scientific uncertainty as to the existence or extent of risks to human health, the Community institutions may, by reason of the precautionary principle, take protective measures without having to wait until the reality and seriousness of those risks become fully apparent'. ${ }^{58}$ Accordingly, in such a situation, 'a risk assessment cannot be required to provide the Community institutions with conclusive scientific evidence' of the reality or the seriousness of that risk. ${ }^{59}$ On the other hand, the same case law is cited by the CFI as authority for the proposition that 'a preventive measure cannot properly be based on a purely hypothetical approach to risk, founded on mere conjecture which has not been scientifically verified'. ${ }^{60}$ What this means is that a preventive measure can be taken only where, even if the existence and extent of a risk have not been conclusively established, that risk nevertheless appears 'to be adequately backed up by the scientific data available at the time when the measure was taken'. ${ }^{61}$

It is already apparent from the previous discussion of the difference between a decision under risk and a decision under ignorance that the CFI's use of language here is unhelpfully loose, even if, digging beneath the surface of the words employed, it appears that it is nevertheless managing in essence to distinguish between these two situations. Hope is raised that there might be greater clarity when the CFI goes on to distinguish 'risk' and 'hazard', ${ }^{62}$ but it immediately muddies the waters further when it asserts that in a case such as this, the purpose of a risk assessment is to assess the degree of probability of a certain product having adverse effects on human health and the seriousness of any such adverse effects'. ${ }^{63}$ This is further compounded when the court proceeds to suggest that 'it is for the Community institutions to determine the level of protection which they deem appropriate for society'. While that is undoubtedly true and entirely unobjectionable, the way in which the Court expresses this fact is less than felicitous:

It is by reference to that level of protection that they must then ... determine the level of risk - i.e. the critical probability threshold for adverse effects on human health and for the seriousness of those possible effects - which in their judgement is no longer acceptable for society and above which it is necessary, in the interests of protecting human health, to take protective measures in spite of any existing scientific uncertainty. ${ }^{64}$ 
The problem here, of course, is that the expression 'critical probability threshold' is meaningless in the context of a decision under ignorance (which the court has previously correctly identified as the appropriate location for the deployment of the precautionary principle) where it is precisely impossible to assign probabilities to different choices. The fact that the court has persisted in using the term 'risk assessment' in the context of precautionary decision situations may well explain why it has been misled in to discussing probabilities where their absence is actually the defining characteristic. This is all the more unfortunate because in other places the court seems much clearer on this point, for example, where it recognises that it may prove impossible to carry out a full risk assessment ... because of the inadequate nature of the available scientific data. ${ }^{65}$ Indeed, the court goes so far as to note that 'unless the precautionary principle is to be rendered nugatory, the fact that it is impossible to carry out a full scientific risk assessment does not prevent the competent public authority from taking preventive measures' ${ }^{66}$ In essence, it appears that provided the public authority has carried out the most thorough scientific assessment possible in the circumstances and provided it is not proceeding on the basis of mere conjecture, then the court will not interfere with the decision to take preventive measures. ${ }^{67}$

At this point, the court takes the opportunity to discuss further the extent to which precautionary decisions are open to review. The court is clear that 'Community institutions enjoy a broad discretion regarding definition of the objectives to be pursued and choice of the appropriate means of action.' As a consequence, the courts may only intervene where 'such discretion is vitiated by a manifest error or a misuse of powers' or where the institutions have 'clearly exceeded the bounds of their discretion'. ${ }^{68}$ Where, as in the present case, the institutions have had to 'evaluate highly complex scientific and technical facts, judicial review of the way in which they did so must be limited'. Furthermore, the court is 'not entitled to substitute its assessment of the facts for that of the Community institutions'. ${ }^{69}$ In this regard, in so far as the institutions took account both of the 'seriousness of the repercussions' should the relevant antibiotic resistance actually be transferred from animals to humans, and of the relevant scientific research, the court concludes that they 'did not make a manifest error of assessment when they came to weigh up their obligations' ${ }^{70}$ The institutions were certainly not obliged, as Pfizer had contended, to wait for the first human death as a result of the relevant antibiotic resistance, before taking action. ${ }^{71}$ As a consequence, 'the Community institutions did not exceed the bounds of the discretion conferred on them' when they concluded that the scientific information available was 'not mere conjecture but amounted to sufficiently reliable and cogent scientific evidence' for the hypothetical link between the use of virginiamycin in animal feed and human antibiotic resistance. ${ }^{72}$

The question remains as to the extent to which the court would be willing to look more deeply into the grounds for the decision taken by the 
institutions. At one point, the court seems to indicate that it has engaged in an exercise of comparing the plausibility of the competing arguments when it states that 'Pfizer's arguments that the development of streptogramin resistance in humans can be more plausibly explained by other factors cannot be accepted'.$^{73}$ But it shortly after seems to indicate the contrary when it states that 'It is not for the Court to assess the merits of either of the scientific points of view argued before it and to substitute its assessment for that of the Community institutions.' Rather in so far as the 'Community institutions could reasonably take the view that they had a proper scientific basis for a possible link, the mere fact that there were scientific indications to the contrary does not establish that they exceeded the bounds of their discretion in finding that there was a risk to human health'. ${ }^{74}$

This consideration of the Pfizer judgment commenced with the observation that there appear to be two main obstacles to meaningful judicial review of precautionary decisions and the foregoing discussion of the case surely only supports this observation. The language of the court clearly does appear to indicate either a difficulty in separating decisions under risk from decisions under ignorance or at least sufficient looseness in the use of terminology to allow this impression to be formed. Similarly, references to 'risk assessment' and 'critical threshold probability' at the very least give the impression that judges are unclear as to requirements to be met in implementing the precautionary principle in order to be able to ensure the procedural adequacy of such decisions. Does this mean that precautionary decisions are not amenable to meaningful judicial review? If so, then the practical usefulness of the principle as a tool of executive decision-making, though defended in the previous section of this chapter, would also be placed in doubt. Furthermore, from a more conceptual perspective, the ability of law to internalise the fragmented problems that engage the precautionary principle, an ability that offers the societal benefit of stabilising normative expectations in the context of significant uncertainty, would be in question.

\subsection{Conclusion}

In seeking to answer those remaining questions, it is important to stress that it is not the point of this chapter to second-guess the court as regards whether or not it was right to decide in favour of the Community institutions and against Pfizer. What the preceding analysis surely does show, however, is that the controversy that has surrounded the judicial review of precautionary decision could be abated were there to be greater clarity in the language used by the courts and, of course, in the first instance by the decision-makers themselves. Were it to be the case that precautionary decision-making proceeded on the basis of the two tests of plausibility of the hypothetical harm and the reasonableness of the proposed response, this would lead not only to more robust decision-making, but also to greater confidence in the quality of 
the decisions. It would also, it is submitted, provide courts with clear procedural requirements, the adequacy of which it would be a much more straightforward matter to review. Again there is no suggestion that precautionary decisions would suddenly become uncontentious, nor that the judicial review of such decisions would please all parties: the systems theory-inspired analysis of such decisions above revealed the extent to which there is in the context of functional differentiation an irreducible fracture in the understanding of the issues at stake and indeed of the precautionary principle itself. The reflexive reading of the two-test approach, however, focuses on the opportunity they offer for structural coupling - to reiterate, not an intersubjective bridge between normatively closed systems, but rather the creation of an opportunity for a mutual reading of competing constructions both of the issues at stake and of the precautionary principle itself. In so far as judges direct their attention to this reflexive aspect of the two-test approach to the implementation of the principle, they will not only help to ensure that precautionary decisions are procedurally robust, but also, crucially, play a role in ensuring, firstly, that such decisions are not misunderstood as unitary onceand-for-all answers to questions which by their nature reflect, perhaps to the greatest extent, the inevitable fracture of concepts and forms in the context of functional differentiation and, secondly, that the principle itself is not misunderstood as a simplistic algorithm.

\section{Notes}

1 Godard, 2006: 73.

2 Resnik, 2003.

3 Fisher and Harding, 2006.

4 Agenda 21, 1992: para. 1.6.

5 Agenda 21, 1992: para. 1.6.

6 See Boehmer-Christiansen, 1994.

7 Rio Declaration, 1992: Principle 15.

8 Sandin et al., 2002: 288.

9 Popper 1972.

10 Agenda 21, 1992: para. 35.1.

11 Agenda 21, 1992: para. 35.4.

12 Agenda 21, 1992: para. 35.3.

13 Paterson 2007.

14 Resnik, 2003.

15 Resnik, 2003: 331.

16 Resnik, 2003: 332.

17 Charnley, 2000: 3.

18 Peterson, 2003: 71.

19 Godard, 2005: 392.

20 Majone, 2002: 104.

21 See also Haenni, 2003.

22 Majone, 2002: 104.

23 See Fairchild v Glenhaven Funeral Services Ltd and others, [2002] UKHL 22.

24 Paterson, forthcoming. 
25 Resnik, 2003: 339; see also Kohlas and Besnard, 1995.

26 Resnik, 2003: 341-42; see also European Commission, 2000.

27 European Commission, 2000: 21.

28 Majone, 2002: 101.

29 Majone, 2002: 107.

30 Lebessis and Paterson, 2001.

31 Horton, 2004.

32 Luhmann, 1995.

33 Luhmann, 1997.

34 Luhmann, 1993.

35 Fisher and Harding, 2006.

36 Luhmann, 1992; King, 2006.

37 Teubner 1993; Paterson and Teubner, 1998; Paterson, 2006.

38 Habermas, 1986, 1989, and see Paterson, 2003.

39 Philippopoulos-Mihalopoulos, 2007.

40 Fisher and Harding, 2006.

41 Fisher and Harding, 2006: 114.

42 Deville and Harding, 1997.

43 European Commission, 2000.

44 Fisher and Harding, 2006: 129.

45 Fisher and Harding, 2006: 131.

46 Fisher and Harding, 2006: 121-32.

47 Charnley, 2000: 3; Charnley and Elliot, 2002: 10366.

48 Fisher, 2001.

49 Basse, 2007.

50 Hollo, 2007.

51 Bugge, 2007.

52 Michanek, 2007.

53 Scott and Vos, 2002.

54 Fisher, 2001.

55 Case T-13/99, [2002] All ER (D) 58 (Sep).

56 Para. 113.

57 Para. 127.

58 Para. 139, citing United Kingdom v Commission, Case C-180/96; National Farmers' Union and others, Case C-157/96, and the judgment of the CFI in Bergaderm and Goupil v Commission, Case T-199/96.

59 Para. 142.

60 Para. 143, citing additionally EFTA Surveillance Authority v Norway, Case E-3/00.

61 Para. 144.

62 Para. 147.

63 Para. 148.

64 Para. 151.

65 Para. 160.

66 Para. 160.

67 Para. 162. See also para. 172.

68 Para. 166.

69 Para. 169.

70 Para. 387.

71 Para. 388.

72 Para. 389.

73 Para. 390.

74 Para. 393. 


\section{Bibliography}

Agenda 21, Earth Summit: The United Nations Programme of Action from Rio, United Nations Conference on Environment and Development, Rio de Janeiro, 3-14 June 1992, http://www.un.org/esa/dsd/agenda21/.

Basse, E. M., 'Comparative analysis of the precautionary principle in the Nordic countries: Denmark', in Implementing the Precautionary Principle: Approaches from the Nordic Countries, EU and USA, ed. Nicolas de Sadeleer, London and Sterling VA: Earthscan, 2007.

Boehmer-Christiansen, S., 'The precautionary principle in Germany: enabling government', in Interpreting the Precautionary Principle, ed. O'Riordan, T. and Cameron, J., London: Cameron May, 1994.

Bugge, H. C., 'Comparative analysis of the precautionary principle in the Nordic countries: Norway', in Implementing the Precautionary Principle: Approaches from the Nordic Countries, EU and USA, ed. Nicolas de Sadeleer, London and Sterling VA: Earthscan, 2007.

Charnley, G., 'Risk analysis under fire', RISK newsletter, first quarter, 3, 2000.

Charnley, G. and Elliott, E. D., 'Risk versus precaution: environmental law and public health protection', 32 Environmental Law Reporter 2, 10363-66, 2002.

Deville, A. and Harding, R., Applying the Precautionary Principle, Sydney NSW: Federation Press, 1997.

European Commission, Communication from the Commission on the Precautionary Principle, COM (2000) 1.

Fisher, E., 'Is the precautionary principle justiciable?', 13 Journal of Environmental Law 3, 315-34, 2001.

Fisher, E. and Harding, R., 'The precautionary principle and administrative constitutionalism: the development of frameworks for applying the precautionary principle', in Implementing the Precautionary Principle: Perspectives and Prospects, ed. Fisher, E., Jones, J. and von Schomberg, R., Cheltenham and Northampton MA: Edward Elgar, 2006.

Godard, O., 'Le principe de précaution et la proportionalité face à l'incertitude scientifique', in Rapport public 2005 : Jurisprudence et avis de 2004 : Responsabilité et socialisation du risqué, Etudes et documents 56, ed. Conseil d'Etat, Paris: Conseil d'Etat, 2005.

Godard, O., 'The precautionary principle and catastrophism on tenterhooks: lessons from a constitutional reform in France', in Implementing the Precautionary Principle: Perspectives and Prospects, ed. Fisher, E., Jones, J. and von Schomberg, R., Cheltenham and Northampton MA: Edward Elgar, 2006.

Habermas, J., The Theory of Communicative Action, Cambridge: Polity Press, Vols 1, 1986, and Vol. 2, 1989.

Haenni, R., 'Ignoring ignorance is ignorant', Philosophy and Probability Working Paper 6, Center for Junior Research Fellows, University of Constance, 2003.

Hollo, E., 'Comparative analysis of the precautionary principle in the Nordic countries: Finland', in Implementing the Precautionary Principle: Approaches from the Nordic Countries, EU and USA, ed. Nicolas de Sadeleer, London and Sterling VA: Earthscan, 2007.

Horton, R., MMR: Science and Fiction: Exploring the Vaccine Crisis, London: Granta Books, 2004. 
King, M., 'What's the use of Luhmann's theory?', in Luhmann on Law and Politics, ed. King, M. and Thornhill, C., Oxford: Hart Publishing, 2006.

Kohlas, J. and Besnard, P., 'An Algebraic Study of Argumentation Systems and Evidence Theory', Technical Report 95-13, Theoretical Computer Science Research Group, University of Fribourg, 1995.

Lebessis, N. and Paterson, J., 'Developing new modes of governance', in Governance in the European Union, ed. De Schutter, O., Lebessis, N. and Paterson, J., Luxembourg: Office for Official Publications of the European Communities, 2001.

Luhmann, N., 'Some problems with reflexive law', in State, Law and Economy as Autopoietic Systems, ed. Teubner, G. and Febbrajo, A., Milan: Guiffré, 1992.

Luhmann, N., Risk: A Sociological Theory, Berlin and New York: de Gruyter, 1993.

Luhmann, N., Social Systems, Stanford CA: Stanford University Press, 1995.

Luhmann, N., 'Limits of steering', 14 Theory, Culture and Society 1, 141-57, 1997.

Majone, G. 'What price safety? The precautionary principle and its policy implications', 40 Journal of Common Market Studies 1, 89-109, 2002.

Michanek, G., 'Comparative analysis of the precautionary principle in the Nordic countries: Sweden', in Implementing the Precautionary Principle: Approaches from the Nordic Countries, EU and USA, ed. Nicolas de Sadeleer, London and Sterling VA: Earthscan, 2007.

Paterson, J., and Teubner, G., 'Changing maps: empirical legal autopoiesis', 7 Social and Legal Studies 4, 451-86, 1998.

Paterson, J., 'Trans-science, trans-law and proceduralisation', 12 Social and Legal Studies 4, 523-43, 2003.

Paterson, J., 'Reflecting on reflexive law', in Luhmann on Politics and Law: Critical Appraisals and Applications, ed. King, M. and Thornhill, C., Oxford: Hart Publishing, 2006.

Paterson, J., 'Sustainable development, sustainable decisions and the precautionary principle', 42 Natural Hazards, 515-28, 2007.

Paterson, J., 'Law's approach to harm in the context of scientific uncertainty: observations from precaution and indeterminate causation', in Perspectives on Causation, ed. Goldberg, R., Oxford: Hart Publishing, forthcoming.

Peterson, M., 'Transformative decision rules', 58 Erkenntnis, 71-85, 2003.

Philippopoulos-Mihalopoulos, A., Absent Environments: Theorising Environmental Law and the City, Abingdon: RoutledgeCavendish, 2007.

Popper, K., The Logic of Scientific Discovery, rev. edn, London: Hutchinson, 1972.

Resnik, D., 'Is the precautionary principle unscientific?', 34 Studies in History and Philosophy of Biological and Biomedical Sciences, 329-44, 2003.

Rio Declaration, Report of the United Nations Conference on Environment and Development, Rio de Janeiro, 3-14 June 1992, Annex I, Rio Declaration on Environment and Development, http://www.un.org/documents/ga/conf151/ aconf15126-1annex1.htm.

Sandin, P., Peterson, M., Hansson, S. O., Rudén, C. and Juthé, A., 'Five charges against the precautionary principle, 5 Journal of Risk Research 4, 287-99, 2002.

Scott, J. and Vos, E., 'The juridification of uncertainty: observations on the ambivalence of the precautionary principle within the EU and the WTO', in Good Governance in Europe's Integrated Market, ed. Joerges, C. and Dehousse, R., Oxford: Oxford University Press, 2002.

Teubner, G., Law as an Autopoietic System, Oxford: Blackwell, 1993. 


\title{
Biotechnology as environmental regulation
}

\author{
Alain Pottage
}

\section{I Introduction}

What should we make of the prospective evolution of biotechnological artefacts into means - rather than simple objects - of environmental regulation? What might be the effects of engineering regulatory norms into the very artefact that is to be regulated? These questions are prompted by the development of a particular approach to the regulation of genetically modified crops, namely, the technique of biological 'containment'. In 2004, as part of a research initiative designed to facilitate the policy of 'coexistence' between GM and non-GM crops, ${ }^{1}$ the European Union funded a programme of research into a set of biotechnological strategies to prevent gene flow from transgenic to conventional plants. The terms of reference of the Transcontainer programme characterise its principal objective as the development of 'genetically modified (GM) crop plants that are "biologically contained":

[I]n order to reduce significantly the potential spread of transgenes of such GM crop plants to conventional and organic crop plants and to wild or weedy relatives, when such exist. Coexistence of GM crops and non-GM crops can be promoted through the implementation of biological transgene containment strategies, while at the same time the potential flow of transgenes from GM crops to wild relatives can be reduced significantly. ${ }^{2}$

Plants would be programmed to function in accordance with regulatory objectives framed by EU bodies and implemented by national authorities. Ultimately, if this approach were taken further, regulatory instruments directed to the behaviour of farmers might be obviated by measures written into the behaviour of the organism itself. It is not yet clear what the ultimate effects of Transcontainer technology and its likely successors will be, but the question of how politics might be inscribed in biotechnological artefacts is a question with a future.

With the theme of this volume in mind, the question is engaging because it divides two ways of thinking about law and ecology. On one hand, the 
prospect of inscribing norms (or politics) into the texture of an organism suggests that the contingencies of regulatory processes - the effects of negotiation, translation, and reflexivity - might be effectively bypassed by technical means. Regulation would become a truly instrumental art. In that sense, bioengineered regulation promises to realise the basic understanding of regulation (and law more generally) as an instrumental operation. Most theories of regulation start from that premise; however 'responsive' it might take regulation to be, theoretical explanation begins within the instrumentalist ambitions of regulatory schemes and introduces social complexity or contingency only secondarily, as a factor that limits or complicates the realisation of instrumental interventions. Even if regulatory measures are not directly enforceable, even if they have to take into account the peculiar cultures of corporate or administrative actors, and even if regulators have strategically to scale up or down through the orders of a 'regulatory pyramid' to find the right means of influence, all of these operations are characterised a priori by the will to instrumentality.

Alternatively, one might approach regulation from the perspective of what Hanjo Berressem (2010) characterises as 'radical paradoxical logic'. ${ }^{3}$ From this perspective, any means/ends schema is, precisely, a 'schematisation'; ${ }^{4}$ that is, it is a way of modelling the world that is referable to a specific observer or observational idiom. The instrumentalist view of the world assumes that the facts - persons and things - which have to be ordered 'ecologically' pre-exist regulatory observation and intervention. The reality, however, is that regulators can only see what they can see, ${ }^{5}$ and what they can see is an effect of their observational schemata. The crucial point is not that the 'ecology' that is apprehended and modelled through the viewfinder of a regulatory discourse is a construct; it is that this specific 'ecology' is just a fold ${ }^{6}$ in the broader ecology of systems or discourses in which regulation is implicated. 'Ecology' appears twice over: as what is seen from within the 'internal point of view' of practitioners or theorists of regulation, and as the differentiated set of discursive processes which condition this internal point of view. What is interesting is the articulation of these two ecologies, which is the point at which paradoxical logic emerges: ecologies in the first sense are immersed in - or immanent in - ecology in the second sense. The conventional, instrumentalist, take on regulation law sees only one 'ecology' - the schema of a common plane across which causative interventions lead (more or less directly or efficiently) to effects - and externalises the processes from which this ecology precipitates and within which it is held steady. These processes - which make up ecology in the second sense - are paradoxical in ways that might be characterised in different ways, depending on one's preferred theoretical idiom. Crudely, social configurations or assemblages are emergent; their being, and that of their elements, does not pre-exist their association and articulation. Readers of Niklas Luhmann will be familiar with the sense in which paradoxicality is made productive by operations 
which fold distinctions into distinctions. But what does all this mean for a study of regulation through technology?

What is in question is the materiality and instrumentality of regulatory technologies. In a now classic exploration of the senses in which 'artefacts have politics', Langdon Winner drew out the ways in which politics might be realised in technical or material means: 'The issues that divide or unite people in society are settled not only in the institutions and practices of politics proper, but also, and less obviously, in tangible arrangements or steel and concrete, wires and transistors, nuts and bolts. ${ }^{7}$ The most celebrated examples are the low overpasses that Robert Moses built over Long Island parkways in the mid-twentieth century; Moses designed these overpasses with headroom of only $9 \mathrm{ft}$ expressly so as to restrict the use of the parkways, the beaches and other recreational facilities that they served to the affluent middle classes, who travelled in private cars, and to exclude poorer people and African Americans, who were more likely to travel in tall buses. ${ }^{8}$ Transcontainer technology might be taken as a contemporary example of the programme of engineering politics into material or technical artefacts. Certainly, some representations of Transcontainer technology ${ }^{9}$ pick up on the sense in which regulation through technology might cut through social contingency by materialising specific means/ends operations, and by automatically generating certain effects in the world. This is where Luhmann's version of 'paradoxical logic' comes in: materialities (and instrumentalities) are an effect of observation. The schemata that frame or fix materiality and instrumentality - the categories of form, extension, motion, causation or effect - are referable to an observer. Materiality and instrumentality are effects of schematisation. More important, these diverse observational idioms or perspectives are reciprocally engaged. The schematisation of a material thing or instrumental operation from any particular perspective will be conditioned by what is seen and said in other observational idioms.

Again, all of this will be familiar to amateurs of radical paradoxical logic. Here, the point is that technological means are just as contingent as the institutional arrangements that they are supposed to bypass; the observation of technologies is integral to what they are and what they do. Materiality is an effect of the terms in which it is observed or schematised, and there are as many materialities (in one) as there are observers or idioms of observation. 'Materiality is sociality'; ${ }^{10}$ that is, materialities that seem to ground or predetermine associations or assemblages of actors or discourses are actually emergent effects of those associations or assemblages. Emergence does not preclude durability. Materialities remain durable, and instrumentalities continue to function instrumentality, because they are contextualised within emergent ecologies whose elements are bound by relations - relations of double contingency, a courbe machinique, or an exchange of competences - in which contingent forms are continuously reiterated or 'refreshed'. Nonetheless, this is still durability within contingency. The sociality that sustains materiality 
can be reconfigured, more or less dramatically, as the inflection of these bonds shifts; as, for example, the knowledge of plant genetics evolves, as legislators respond to public anxieties about GM crops, or as courts develop innovative schemata of causation and liability. Transcontainer technologies can be understood as nexuses within just this kind of (paradoxical) sociality; their materiality and instrumentality is a contingent 'ecological' effect.

\subsection{Antecedents}

In a report published in 2007, the ETC Group traced the origins of the Transcontainer project to the development of genetic use restriction technologies so-called 'terminator technologies'. Genetic use restriction technologies were initially developed as means of engineering intellectual property rights into the behaviour of transgenic plants. Conventional intellectual property rights share the essential limitation of conventional regulatory measures: texts are not self-implementing. The scope and effectiveness of a right depends on the means available to enforce it, and processes of enforcement imply negotiation, translation, and adaptation. Given these limitations the appeal of terminator technologies is obvious. So long as the only economically viable way of exacting royalty payments for seeds is to charge a 'technology fee' related to each successive generation of crops (rather than capitalising anticipated royalties in a single (prohibitive) premium) breeders somehow have to prevent farmers from evading these technology fees by reproducing saved seed. By preventing the reproduction of seeds through second and subsequent generations, terminator technologies would effectively compel farmers to return to suppliers to buy proprietary (and royalty-bearing) seeds each season. So terminator technologies promised to turn plants into the perfect commodity, a form in which, for the first time, rights would be directly inscribed in the essential texture of things. The technology 'explicitly produces property (or, reproduces the plant as property) $;{ }^{\prime 1}$ proprietary rights are 'embedded in the material itself';12 ownership is written 'into the genome'. ${ }^{13}$ From this perspective, terminator technologies promise to enforce patent rights without reference to jurisdictional or cultural limits:

In the agricultural sector, it is possible to foresee the imminent demise of the IPR system as the primary means for channeling returns from innovations to innovators. The advent of genetic use restriction technologies foretells of a future in which seed patents and plant variety legislation is a 'thing of the past'. Future biological innovations will be protected biologically. ... Every country will exist within a 'one size fits all' system that has perfectly enforceable innovation appropriation. ${ }^{14}$

The technique of hybridisation, which was adopted in the early twentieth century, has precisely the same economic effects as terminator technology. 
Crop yields drop significantly in the $\mathrm{F}_{2}$ generation, so fresh seed stock has to be purchased each season. However, some important crops (notably cotton, rice, wheat and soya bean) are not amenable to hybridisation, so breeders are obliged to turn from biological appropriation strategies to legal instruments: trade secrets, shrink-wrap licences, grower agreements, patents and plant variety rights. These crops are the most obvious candidates for the first applications of genetic use restriction technology.

The ambition of genetic use restriction technologies is to automate intellectual property. What does this ideal of automation involve? First, the objective of terminator technologies is to recruit technology as the means of making property rights truly exclusionary. A complex array of gene constructs is composed into a gene switch ${ }^{15}$ that, once activated, would effectively prevent plants from reproducing seeds (and hence the patentable 'invention'). The business of making a gene switch that could function so precisely and reliably as to draw an absolutely hermetic proprietary boundary is far from straightforward, but what is crucial for present purposes is what this ideal (and its representation in critical commentary) says about the institution of property. The representation of terminator technology as a means of perfecting property implicitly reduces conventional, textual, property institutions to the kind of instrumentality that is supposed to constitute the essence of technology. The ambition of terminator technology, which was also reflected in critical commentary and in the use of the 'terminator' epithet, is (finally) to instrumentalise property rights. But if we take materiality and instrumentality as effects of observation, then things are not so straightforward. Far from curtailing processes of negotiation, translation and reflexivity, the technology becomes an occasion for their renewal; more precisely, the technology itself becomes a medium through which these processes are articulated. The meaning and effect of the technology - quite simply, what the technology is and what it does - becomes an effect of the association of diverse (and often opposing) interpretations.

To some extent, this effect is visible in the history of genetic use restriction technologies. When the question of terminator technology was taken up by the 1999 meeting of the Subsidiary Body on Scientific, Technical, and Technological Advice (SBSTTA) of Convention on Biological Diversity (CBD), its commercialisation was opposed on grounds of bio-safety. The draft recommendation that emerged from the meeting of the SBSTTA invoked the precautionary principle in support of the proposition that "products incorporating [terminator] technologies should not be approved by Parties for field testing until appropriate scientific data can justify such testing, and for commercial use until appropriate, authorized and strictly controlled scientific assessments ... have been carried out in a transparent manner'. ${ }^{16}$ At the time of writing the so-called 'de facto moratorium' established by this Decision still held. This characterisation produced two alternative responses from proponents of terminator technology. The first was discursive or institutional, and 
consisted in a challenge to the precautionary premises of the 2000 Decision. At the 2006 Curitiba meeting of the COP to the CBD, a group of nations made a sustained but ultimately unsuccessful attempt to argue that the precautionary principle should be replaced by a procedure of case-by-case costbenefit analysis. The second strategy involved an ironic turn to technology. If the basic objection to terminator technologies was premised on bio-safety, why not turn the technology itself into a bio-safety device? Even if, technically, the essentials of gene switch technology remained the same, the 'technology' in the sense of a purposive intervention took on a very different character. The inherent potentiality of the technologies, and perhaps even their 'original' design, became an effect of the reciprocal inflection of diverse actors or discourses.

The innate adaptability of terminator technology manifested itself soon after the publication of the first patent. A technical report produced for the 1999 meeting of the SBSTTA distinguished between two possible forms of genetic use restriction technology: the original terminator technology, now renamed as a 'variety-specific' genetic use restriction technology, and a newer form of 'trait-specific' technology. Unlike the variety-specific form, trait-specific technologies would allow seeds to be reproduced into subsequent generations, but would block the expression of a particular (proprietary) trait. From the point of view of the farmer, these traits would become optional extras. They would be carried by all successive generations of the plant, pending activation by an external agent which could be bought (under license) from the producer. The virtue of the new variant was said to be that it might 'eventually provide an empowering mechanism to allow public and private priorities to be partially reconciled' (ibid: 14). Terminator technologies were on their way to becoming bio-safety technologies. Gene switch technologies were soon to be promoted as means of excising transgenes from modified plants, either by excising them from the whole plant once they had served their purpose, or by excising them from those parts of the plant in which they were either redundant (for example, a gene construct conferring a mode of pest control may be required only in the roots of the plant) or commercially undesirable (notably fruits or seeds). An editorial in Nature Biotechnology characterised this evolution in terms of the plot of the movie Terminator 2, observing that the 'new Terminator technology, like the robot in Terminator 2, would, it is envisaged, be a humbler, kindlier beast. Its role would not be to prevent resource-poor farmers from gaining illegal access to GM crops. It would be an environmental control mechanism - a way of reducing the unwanted spread of transgenes in field situations'. ${ }^{17}$

\subsection{Coexistence}

According to the ETC Group, the Transcontainer programme is a direct evolution of these more responsive terminator technologies. Politically, the 
appeal of biological containment strategies was said to be that they offered a technical solution to public concerns about the environmental impacts of transgenic plants:

[Agricultural biotechnology's] future commercial success depends on finding a plausible techno-fix to prevent leaky genes from escaping. If governments can be convinced that biological containment of GMOs is technically possible, it will open the floodgates to new markets for GM crops, and commercial-scale production of GM pharmaceutical plants (plants engineered to produce drugs), and GM industrial crops (plants engineered to produce chemical compounds for industrial use), as well as GM trees. ${ }^{18}$

Indeed, according to the ETC Group, the 'double back-up systems' that were proposed by the Transcontainer project promised to make the separation of GM and non-GM crops even more radically and effectively than 'Terminator 2' technology could ever have done. ${ }^{19}$ What this characterisation brings to the fore is the sense of technology as an ultimate realisation of legality; technology reduces legal action to its instrumental essence (in this case the law in question is the law relating to food and agriculture rather than the law of property). Yet, in their response to the ETC Group, the directors of the Transcontainer project observed that only one of the seven containment strategies explored by the project has any technical similarities with terminator technology, and even here the objective of the containment strategy 'is not to restrict the use of the seeds of biologically contained GM crops but to facilitate coexistence with non-GM crops' ${ }^{20}$ The basic premise of the European Union's policy of 'coexistence' is that '[n]o form of agriculture, be it conventional, organic, or agriculture using GMOs, should be excluded in the European Union'. ${ }^{21}$ Restating this premise, the Transcontainer project's response to the ETC Group argued that the project 'is not conducted under the guise of bio-safety [but] with the aim to facilitate the coexistence of GM crops and non-GM crops' ${ }^{22}$ In what sense is the realisation of coexistence different from the realisation of bio-safety?

Regulatory policy in the European Union starts from the premise that 'coexistence is not about environmental or health risks because only GM crops that have been authorised as safe for the environment and for human health can be cultivated in the EU'. ${ }^{23}$ Once the cultivation of GM crops has been authorised by the European Food Safety Authority, following an assessment of the environmental impact of the crops and their specific mode of cultivation, ${ }^{24}$ their coexistence with conventional and organic crops becomes an economic and regulatory question: 'coexistence is concerned with the potential economic loss through the admixture of GM and non-GM crops which could lower their value'. ${ }^{25}$ The basic axiom of coexistence is freedom of choice: producers should be free to engage in their chosen mode of 
agricultural production without being unfairly - or 'disproportionately'26 prejudiced by the activities of other growers, and consumers should be free to exercise their preferences for the material, efficient or symbolic qualities of one or other kind of product. Freedom of choice presupposes clear product differentiation, so the EU's coexistence regime is based on the mandatory labelling of products containing GMOs. GM and non-GM products are distinguished by reference to a threshold criterion: so long as the presence of GM DNA is no more than 0.9 per cent of the product, and so long as the presence of these traces is truly 'adventitious', ${ }^{27}$ that product will still qualify for labelling as a product of conventional or organic agriculture. The reference to a threshold criterion recognises a basic implication of maintaining a heterogeneous agricultural regime; contamination of one production line by another is bound to take place by means of, for example, the inadvertent commingling of seed stock, gene flow across crops, or the incorporation of residues left in farm machinery, transport vehicles, or silos used alternately for GM and non-GM crops. ${ }^{28}$

This is the point at which the economic dynamic of coexistence emerges. How does one balance the interests of GM growers and non-GM growers? Of itself, the adoption of GM agriculture imposes costs on conventional farmers. For so long as consumers continue to differentiate between GM and non-GM crops, and to regard the latter as inferior to the former, then nonGM growers in an unregulated regime of agricultural production would have to take on the costs of measures to ensure the purity of their products. On the other hand, given the practical inevitability of commingling or contamination, a labelling regime that insisted on 0 per cent presence of traces of GM crops in non-GM crops would effectively extinguish GM cultivation. So the point of introducing a non-zero tolerance of (adventitious) contamination is to institute a balance between the interests of the two constituencies or, quite simply, to make some form of coexistence possible. The question then is how to institute the right balance. How should ex ante regulatory rules - essentially rules requiring growers to register GM holdings, to notify their neighbours of GM crop fields, and to cultivate GM crops at specified distances from conventional crops - be framed so as not to create immediate disincentives to the cultivation of GM crops? How far, on the other hand, can one go in facilitating GM cultivation without risking exceeding the threshold of 0.9 per cent 'adventitious' GM content? These questions go to the nature of the ecology in which biological containment devices will operate.

\subsection{Regulatory ecology}

A few years ago, Jürgen Habermas warned that biotechnologies were collapsing the traditional, 'categorical', distinction between the made and the grown, or between 'what is manufactured and what has come to be by nature. ${ }^{29}$ Although the genetic constitution of domesticated species has been 
profoundly modified by centuries of artificial selection, these methods of breeding consisted in an essentially 'therapeutic' mode of intervention, premised on 'a clinical mode of adjustment to the inherent dynamic of nature. ${ }^{30}$ Breeders merely inflected the natural process of growth and evolution, but biotechnologies reduce living tissues and organisms to inert components which can be engineered and programmed: "what hitherto was "given" as organic nature, and could at most be "bred", now shifts to the realm of artefacts and their production'. ${ }^{31}$ The EU's policy of coexistence quite straightforwardly assumes that the distinction between the made and the grown has already collapsed; or, indeed, that it never existed. According to the European Commission, coexistence is merely the latest variation on a timeless practice:

The issue of coexistence is actually as old as agriculture itself. Over numerous generations, the genetic make-up of farmed plants varies significantly from their wild relatives, and cross-pollination is usually regarded as undesirable. In the case of GMOs, there is also the need to ensure that modified genes do not accidentally migrate to conventional, organic, or wild plant species, particularly in the case of genetically modified non-food plants. ${ }^{32}$

Implicitly, by reducing plants to their 'genetic make-up', and hence to a mode of existence that emerged only with the rise of the science of genetics and the business of biotechnology, this proposition represents biotechnological 'making' as the common techne of natural selection, traditional breeding practices, and biotechnological intervention. For present purposes, the eclipse of the old distinction between the made and the grown is less interesting than the fact that coexistence brings with it a new and specific ecology.

The central axis of this ecology is the regulatory technique of traceability. A label is reliable only if it refers to a product whose (relative) purity can be guaranteed, and to guarantee purity one has to be able to follow a product through from its emergence to its point of sale. Formally, traceability means 'the ability to trace and follow a food, feed, food-producing animal or substance intended to be, or expected to be incorporated into a food or feed, through all stages of production, processing and distribution'. ${ }^{33}$ The EU's coexistence regulation prescribes that all products 'consisting of' GMOs (a whole plant or fruit), products 'containing' GMOs (processed plants or fruits), food 'produced from' GMOs (e.g. oils produced from seeds or sugar produced from sugar beet), and animal feed 'produced from' GMOs should be traceable through all stages of their progress 'from farm to fork' ${ }^{34}$ Those involved in the production, transport, storage, and distribution of these food products are responsible for ascertaining their provenance and immediate destination, ${ }^{35}$ and they are required to retain for at least five years all the documents, samples and test results that they might be called upon to supply 
to establish how a traceable product passed through their hands. These obligations are complemented by an assemblage of national inspection procedures that can, where necessary, be mobilised to make the whole trajectory of a GMO and its products visible to regulators. This is regulation as a politics of control, in the specific sense of 'inspection' or 'verification'. ${ }^{36}$ The subjects of a regulatory regime can be called to account at various points and by various means, but these subjects are left to - indeed, have to - schematise and 'integrate' controls into their own ecological horizons in ways that will feed back into the structure and operation of regulatory controls.

The EU's regime of traceability identifies each GMO by reference to 'the transformation event from which it was developed'. ${ }^{37}$ The category of the 'transformation event' refers to the specific act (and effect) of inserting a gene construct in a host organism. Each such act generates a unique molecular pattern that is produced at 'the junction areas, the two regions where the transgenic DNA is "welded" to the genome of the host organism'. ${ }^{38}$ Because transgenic modification is a highly random operation, in which transgenic DNA is inserted into the host genome at unpredictable points, the point of 'welding' will be unique to each act of transformation, even where the act manipulates a gene construct and a plant variety that have been combined before. So a transformation event will be specific to each individual product of genetic modification. Laboratories are required to record the creation and marketing of new transformation events rather than new organisms; each transformation event is assigned a 'unique identifier', a code that identifies a GMO for the purposes of authorisation, registration and, crucially, traceability. ${ }^{39}$ The transformation event functions as the index that traces the reproduction and circulation of the products of each specific act of modification. However, it follows from the logic of coexistence that a transformation event does not indicate 'GMO-ness' as a particular category of being; it functions as the trace of a trace, as a signifier whose signification is an effect of its use and interpretation.

To begin with, the category of the transformation event eclipses the distinction between the 'grown' and the 'made'. This point can be made by way of a contrast between the logic of the transformation event and the characterisation of transgenic plants as patentable 'kinds' of plant. In 1999, in a decision that held that transgenic plants were not 'plant varieties' for the purposes of the European Patent Convention and were therefore eligible for patentability under the Convention, ${ }^{40}$ the Enlarged Board of Appeal of the European Patent Office reasoned that traditional plant breeding and biotechnological intervention were different ways of making or (in)forming plants. It was appropriate to limit the breeders of new plant varieties to the protection provided by the legal form of the plant variety right because these rights were 'only granted for specific plant varieties and not for technical teachings which can be implemented in an indefinite number of plant 
varieties' ${ }^{41}$ Whereas traditional breeders created a specific genus of organism, often distinguishable from related varieties only by minor enhancements, the biotechnology corporations created an entirely different order of genus. The genus of a transgenic plant was not, argued the Board, 'an individual plant grouping to which an entire [genetic] constitution can be attributed ... but an abstract and open definition embracing an indefinite number of individual entities defined by a part of its genotype or by a property bestowed on it by that part'. ${ }^{42}$ In other words, the effect of splicing a transgenic construct into a particular kind of plant is to give that plant a new taxonomic and genotypic identity. The transgenic construct expresses the principle of a super-taxon, a genotypic principle that overwrites the identity of any plant into which it is inserted. ${ }^{43}$ For the purposes of European patent law this means that a novel transgenic plant qualifies as an invention because it consists in 'a claim covering but not identifying plant varieties' ${ }^{\text {' }}$ that is, a claim that 'encompasses' plant varieties but whose 'subject matter' is not a plant variety. ${ }^{45}$

The identification of a transformation event does not have the effect of 'genotyping' organisms in this way. The process of fixing and tracing an event does not involve deciding between - or determining priorities between - 'making' and 'growing' as two alternative ways of bringing organisms into existence and of defining their being. In one sense, of course, the form of a transformation event assumes the difference between the grown and the made; the event is formed at the intersection between DNA of these two kinds, namely the DNA of the transgenic construct and the genomic DNA of the host plant. This index of modification then functions as an indicator of the presence of material (re)produced from the originally modified plant. But in the ecology of coexistence the index is not used to distinguish between two kinds of organism, two kinds of formal cause, or two orders of being; rather, it is used to identify the degree of presence of the material indexed by the trace. The practical premise of coexistence policy namely, that the commingling of GMO and non-GMO material is almost certain to happen at some point in a chain of agricultural production means that the difference between GMO and non-GMO is one of degree rather than one of kind. ${ }^{46}$ What distinguishes the terms is not the presence or absence of the trace of the transformation event but the degree to which it is present. ${ }^{47}$ Within the policy of coexistence, the basic function of the trace is to make the difference between minimal (and hence adventitious) presence and substantial (and hence intentional) presence, and this difference is not the difference between two kinds of being but the difference between two strategies of cultivation and two kinds of label (or market appellation).

The difference between GMO and non-GMO production can be framed in different ways, depending on the interest of the observer and the phase of production that is being observed. All the way down a (traceable) line of production, the difference between GM and non-GM production is an 
effect of interpretation. This is the other side of the politics of 'control'; the measures by which actors and their activities are 'controlled' - in the sense of 'verification' - are interpretively (re)constructed by each of the actors in question. This effect is evidenced by the functions of the transformation event as a technique of control. Javier Lezaun observes that the chief virtue (in regulatory terms) of the transformation event is its precision. Earlier techniques for the identification of GMOs detected the presence of the promoter sequences that are common to many transgenic organisms, thereby 'catching multiple GMOs in one single test' ${ }^{48}$ by contrast, the specific molecular pattern identified by the form of the transformation event allows regulators to distinguish between authorised and unauthorised GMOs, and indeed to trace a DNA fragment back to a specific source, agent, and act of modification ${ }^{49}$ Crucially, this quality of specificity facilitates the co-ordination of a diversity of actors or discourses: when those involved in the process of regulation - corporate laboratories, testing agencies, primary and secondary producers, regulators and administrators - talk about potato EH92-527-1 ${ }^{50}$ they can be sure that they all talking about the same thing. But each actor will construe the presence of traces of a transformation event in different ways. For politicians and campaigners against the cultivation of GM crops what is in question is the rationale of the 0.9 per cent threshold, and, perhaps, of the coexistence policy in general. ${ }^{51}$ For producers and distributors the objective is to develop strategies to keep the presence of traces of GM 'events' below the threshold of 0.9 per cent. For testing agencies, the challenge is to maintain the stability and specificity of the form of the transformation event. ${ }^{52}$ How are these held together in practice? This is where the question of ecology returns.

The transformation event illustrates a crucial aspect of the EU's coexistence policy; in eclipsing the old distinction between the grown and the made, coexistence policy comes close to recognising a regulatory ecology in which instrumentality, durability and materiality are emergent effects of sociality. Although coexistence is officially presented and implemented by reference to instrumental effects, coexistence is articulated by the norm which provides that the degree of (adventitious) presence of GMO-derived material should not exceed the threshold of 0.9 per cent in products labelled as non-GMO products. The norm can be integrated in a variety of ways. For example, for those who still take seriously the distinction between the grown and the made, the norm measures a latitude of impurity, and the practical object is to reduce impurity to a minimum by (for instance) ensuring that seed stocks are rigorously differentiated. For farmers considering adopting GM crops the 0.9 per cent norm is a measure of the potential expense of establishing spatial segregation distances (see below), or a measure of their potential liability to neighbouring farmers. For consumers, the 0.9 per cent norm underwrites the validity of labels, and these labels communicate information that can be acted upon in various ways. What is true of the norm is 
also true of the instruments through which it is operationalised: the transformation event, techniques of traceability, and, perhaps, Transcontainer technologies, are similarly diffracted.

\subsection{Ecological modelling}

The objective of the Transcontainer project is 'to facilitate coexistence by containing GM plants next to conventional plants in neighbouring fields'; the premise is that '[containment] has the potential to allow the application of shorter isolation distances between GM plants and fields with conventional or organic crops'.$^{53}$ In other words, biological containment measures are supposed to complement or (partly) replace more conventional techniques for keeping GM and non-GM crops apart. In 2009, a European Commission report reviewed the measures taken by fifteen member states in implementing the principle of coexistence. ${ }^{54}$ The report identified two basic kinds of regulatory measure: the first kind consisted in 'information, registration and training procedures', which (e.g.) require prospective GM farmers to seek authorisation from a public authority before they embark on cultivation, or to notify their neighbours or other interested parties; the second kind consisted in what the report identified as 'technical segregation measures'. ${ }^{55}$ Classically, these 'segregation measures' take two forms: isolation distances and buffer zones (or pollen barriers). An isolation distance sets a fixed, species-specific, distance between GM crop fields and neighbouring non-GM fields with sexually compatible crops, the object being to contain GM pollen drift within a specified radius. Whereas isolation distances are essentially inert barriers, buffer zones surround fields of GM crops with non-GM crops of the same species, the principle being that these sexually compatible plants would effectively absorb gene flow from their GM analogues.

Figuratively, to use Deleuze's distinction between discipline and control, regulatory policy construes both spatial segregation and Transcontainer technologies as modes of discipline (moulding) rather than control (modulation). Plants are localised, identified and contained, either by means of spatial quarantining or by means of techniques that are supposed to make plants inhabit - that is, behave in - space in a specific, predictable, and quasi-mechanical way. Both techniques presume a conventional model of ecology, in which the relations between plants and people play out in an objective spatial extension, which is taken to be the common medium of social and biological existence. The behaviour programmed into 'biologically contained' plants would be a 'behaviour' adjusted to the characteristics of this common 'ecological' domain. For some practitioners of coexistence policy, the advantages of building spatial containment into plants were not clear. The Commission's decision to fund the Transcontainer project apparently 'surprised' some national regulators, for whom spatial segregation techniques were entirely adequate to the task of ensuring coexistence in the phase of 
cultivation. ${ }^{56}$ Although this representation might overlook some of the implications of engineering politics as artefacts, the perception of techniques of biological containment as enhanced versions of existing regulatory techniques is a good place to begin exploring how material technologies are animated by diverse schematisations. Already, the complexities of the spatial measures that might eventually be complemented or replaced by Transcontainer technologies tell us a good deal about the way in which material forms are multiplied by observation.

The difficulties of fashioning an ecology of coexistence are reflected in the variability of spatial segregation distances. In the case of some common GM crops, notably oilseed rape, isolation distances can be quite significant. For example, Luxembourg and Latvia require producers of GM oilseed rape crops to maintain a minimum isolation distance of, respectively, 3,000 $\mathrm{m}$ and 4,000 $\mathrm{m}$ between GM and non-GM crops $^{57}$ In the case of maize, the Commission's report observes that generally 'isolation distances for maize production range between $25 \mathrm{~m}$ and $600 \mathrm{~m}$ with respect to conventional maize and between $50 \mathrm{~m}$ and $600 \mathrm{~m}$ regarding organic maize'. ${ }^{58}$ So, for example, Germany requires cultivators to keep a fixed distance of $150 \mathrm{~m}$ between $\mathrm{Bt}$ maize and conventional maize, and $300 \mathrm{~m}$ between $\mathrm{Bt}$ maize and organic maize. ${ }^{59}$ Before these regulations were promulgated German farmers relied on the recommendations of the GM seed companies, which proposed an isolation distance of only $20 \mathrm{~m} .{ }^{60}$

To begin with, the extent of an isolation distance will depend on the science of plant behaviour. Plants have different pollination behaviours and differing potentials for gene flow by means of pollen drift; ${ }^{61}$ their seeds can be more or less long-lived or viable in the soil seed bank; they have different climate responses and different sensitivities to biogeographical factors such as the prevailing wind, herbivore abundance, the density of pollinating insects, or seedling mortality. These natural propensities establish one context for the calibration of spatial segregation measures. From a regulatory perspective, one has to take into account not only the behaviour of plants in one phase or season of cultivation, but also the likely effects of the accumulation of seeds and other residues in the soil. And any regulatory ecology has to take into account how plants behave in relation to humans. For the most part, accounts of the EU's coexistence policy work within a schematisation that simplifies the contingencies of space. Many accounts are exercises in agricultural economics that start from the assumption that 'each farm [is] managed by a risk-neutral and profit-maximizing decision maker' (farmer). ${ }^{62}$ Given that assumption, the crucial question about existing or proposed spatial segregation measures is how or whether they relate the behaviour of the rational farmer to the behaviour of plants in such a way as to achieve the two basic objectives of coexistence: the objective of choice, which requires proportionality between the two types of cultivation, and the objective of ensuring that GM and non-GM products are actually held separate. The 
terms of reference of the Transcontainer project quite explicitly take this economic matrix as the framework within which the effects of biological containment strategies will be modelled; the project seeks to calculate the 'maximum incremental social tolerable irreversible costs of the usage of GM plants', and hence to explore 'the reversible and irreversible costs and benefits for the private sector (technology providers, farmers, agro-food chain operators, occupational safety for farmers, investment in cultivation machinery, etc.) and the public sector (regulations, environment, biodiversity, etc.) ${ }^{63}$ So the ecology of coexistence is premised on the way that landscapes are apprehended by rational human actors; landscape is the common medium in which plants and humans interact, but it is mapped on a grid of economic co-ordinates and vectors.

Studies in the design of coexistence regulations propose that one should take into account 'the geographical influence of landscape, land fragmentation, and field configuration on the impact of GM crops' ${ }^{64}$ So, for example, if the agricultural landscape is divided into a number of smaller farms, significant isolation distances will be a greater disincentive to the cultivation of GM crops than it would in a landscape of larger farms; the costs of notification and (in certain cases) negotiation will increase in direct proportion to the number of proximate neighbours, and the area of land that has to be kept uncultivated in order to maintain an isolation distance will be proportionally greater than it would be in the case of larger holdings. Similarly, the size of farms, and the nature of farm tenures, will make so-called 'domino effects' more or less likely; farmers deciding whether or not to adopt GM cultivation might be dissuaded by the costs of implementing isolation distances, and as more and more farmers commit to non-GM cultivation they might (collectively) be more concerned to ensure the identity of those non-GM crops, and therefore more likely to insist on maximal compliance with ex ante regulations. The broad point is that spatial regulations have to be responsive to the ways in which rational farmers approach the implementation of ex ante measures. Empirical investigations have given a sense of the factors which shape the perceptions of farmers. For example, a study carried out in Portugal, where farmers are likely to adopt transgenic maize in order to insure against losses caused by the European corn borer, confirmed that fixed isolation distances and intensive registration and information procedures are likely to present smaller farmers with a steeper regulatory gradient. The conclusion was that regulation premised on rigid isolation distances 'reduces rather than supports coexistence'. ${ }^{65}$

In practical terms, this might mean, for example, that buffer zones are better (and more adaptable) regulatory instruments than isolation distances: the area of a buffer zone is usually less extensive than that of an isolation distance; the crop grown in a buffer zone can be harvested and sold (provided it is labelled as a GM product); buffer zones are potentially more flexible than isolation distances because they are (potentially) open to 
negotiation between farmers. ${ }^{66}$ From the perspective of agricultural economics, negotiation is the ideal of regulation. The European Union's coexistence guidelines observe that 'groups of farmers in a neighbourhood may achieve a significant reduction in the costs related to the segregation of GM and non-GM production types if they co-ordinate their production on the basis of voluntary agreements' ${ }^{67}$ In Germany, distances may be modified by private agreement - and ex post liability principles will be modified accordingly. ${ }^{68}$ More broadly, prescriptive regulatory measures are subject to bargaining in much the same way as Coasean logic takes property rules and liability rules as means of bargaining towards economic efficiency.

\subsection{Conclusion}

What does this brief review suggest about the likely ecology of biologically contained plants? Crudely, the effect of Transcontainer technologies would be to minimise zones of spatial containment, and the extent of that effect will depend on the particular technology that is adopted. The Transcontainer project focuses on three particular techniques: 'controllable fertility', which uses gene switches to prevent transgenic plants from producing viable seeds; 'controllable flowering', which would result in non-flowering varieties of crops whose commercial value lies in their vegetative parts; and 'chloroplast transformation', which would eliminate transgenes from plant pollen by engineering constructs into the chloroplasts rather than the nuclear genome ${ }^{69}$ Many of the variables involved in calibrating spatial segregation distances will immediately come into play in deciding which of these techniques to adopt. For example, even if containment techniques do function effectively, the cost of the technology would have to be such as to reduce the gradient faced by potential adopters of GM crops. Crucially, the choice of technique will depend on the nature of the crop. For example, controllable flowering technologies would be viable only in the case of crops (notably trees) whose commercial value is not dependent on the maturation of their flowering parts. Similarly, in the case of flowering crops such as oilseed rape, which disperse pollen over an extensive area and which are therefore ideal candidates for containment by means of controllable fertility technologies, these technologies will be viable only if they overcome the difficulties involved in timing the activation of the gene switch to allow the oil-rich seeds of the plant to mature.

Much will depend on the efficacy and reliability of the technology. When BASF's Amflora potato was approved for cultivation, the European Commission specified that the potato should be cultivated in such a way as to reduce the risks of residue GM potatoes remaining in the soil after harvest, or of tubers being distributed adventitiously. In a sense, because they reproduce asexually, potatoes are less volatile than the flowering plants with which 
the Transcontainer project is concerned; 'genetic drift' is an effect of immediate material contiguity rather than pollen dispersal. But the terms of the authorisation illustrate the point that potential - perhaps unavoidable residues of GM cultivation have significant long-term implications for any regime that is sensitive to the degree of presence of GM products. If GM cultivation becomes effectively irreversible due to the effects of residues, what does that mean for the policy of coexistence? The more crucial point is that cultivation is just one phase in the processes of production traced out by the EU's regime of coexistence. By minimising segregation distances, containment technologies might transform the ecology of cultivation. In the economically mapped landscape of cultivation, segregation distances would no longer have the effect of making GM cultivation uneconomic for certain farmers. But one would still have to ask how cultivation is framed by other phases in the process of agricultural production. What is the likelihood of the 'commingling' of 'contained' seeds and 'non-contained' seeds, whether GM or non-GM? To what extent can the immediate products of 'biologically contained' plants be kept apart from those of non-GM crops? With concerns about the efficacy of the technology in mind, might legislators (re)impose spatial segregation in order to add a 'political safety factor'?"

The likely operation of Transcontainer technologies would be analogous to the operation of other basic technologies of coexistence. By analogy with the form of the transformation event or the operation of traceability procedures, one might say that the instrumentality of containment techniques would be an effect of sociality (that is, sociality as paradoxical multiplicity). That is, as in the case of these analogous techniques, the operation of containment technologies would be framed or conditioned by the basic norm of coexistencethe requirement that non-GM products should contain no more than 0.9 per cent of GM material. To return to a proposition introduced earlier in this chapter, the norm is a variable nexus, or a form 'brings people [or discourses] together because it divides them'. ${ }^{71}$ And although regulatory politics might be inscribed or materialised in the behaviour of plants, this materiality will be as much an effect of observation as that of the transformation event. So the ecology that really matters to the operation of containment technologies is not the linear 'ecology' projected by the regulatory will to instrumentality, but the paradoxical ecology of emergent sociality.

\section{Notes}

1 Between 2004 and 2009 the European Union's Sixth Framework Programme for Research (FP6) funded three associated research projects: the SIGMEA project, which sought to model gene flow by simulating the flow of pollen across a virtual landscape (LandSFACTS), and which simulated the way that (rational) farmers allocate crops to fields (see http://www.inra.fr/sigmea) and the Co-Extra (Co-Existence and Traceability) project, which sought to develop techniques for the traceability of GMOs, ranging from biological methods for detecting GMOs 
to regimes for separating GM and non-GM products throughout the phases of production and distribution, 'from farm to fork' (see http://www.coextra.eu).

2 See http://www.transcontainer.wur.nl/UK/questionsanswers/.

3 Cited by Andreas Philippopoulos-Mihalopoulos in Chapter 1 of this volume (n. 16).

4 This (Kantian) term is taken from one of the principal exponents of 'radical paradoxical logic', Niklas Luhmann. See generally Luhmann 1995.

5 See Luhmann 1989: 22-23: 'In a somewhat different, Wittgensteinian formulation, one could say that a system can only see what it can see.'

6 Or, to borrow John Rajchman's term, 'perplication'; 'creative distantiation in the midst of things' (Rajchman 1998: 17).

7 Winner 1980: 128.

8 Winner 1980: 123-24.

9 See generally ETC Group 2007.

10 See Latour and Lépinay 2008: 47.

11 Van Dooren 2007: 76.

12 CBD 1999: paragraph 108.

13 Van Dooren 2007: 71.

14 Swanson and Goeschl 2005: 693.

15 An animated presentation is set out in the online supplementary materials to Hills et al. (2007).

16 CBD 1999: 47.

17 Keenan and Stemmer 2002: 215.

18 ETC Group 2007: 4.

19 ETC Group 2007: 8, 23-25.

20 Transcontainer 2007b: 2.

21 European Union 2003a, Recital 1.

22 Transcontainer 2007b: 1.

23 European Union 2003a.

24 At the time of writing, the Amflora potato, which was approved for cultivation by the European Commission in March 2010, was the first GM crop to be approved since 1998.

25 European Union 2003a.

26 European Commission 2006: para. 2.1.4.

27 Meaning 'low-level, technically unavoidable and unintended presence' (Directive 2001/18/EC, 29).

28 For a survey of these in relation see Messean et al. 2006.

29 Habermas 2003: 46.

30 Habermas 2003: 46.

31 Habermas 2003: 12.

32 European Commission 2006: 8.

33 European Union 2002: article 3.

34 European Union 2003b.

35 European Union 2003b: article 3.3.

36 See Deleuze 1990.

37 European Union 2003b: article 3.4.

38 Lezaun 2006: 511.

39 The identity of each transformation event - and hence the specificity of each unique identifier - is ultimately guaranteed by a deposit of biological material in the European Commission's Institute of Reference Materials and Measurements.

40 Article 53(b) of the European Patent Convention excludes 'plant or animal varieties' from patentability.

41 European Patent Office 2000: point 3.10. 
42 European Patent Office 2000: para. 3.1.

43 The inventor aims at providing tools whereby a desired property can be bestowed on plants by inserting a gene into the genome of those plants. Providing these tools is a step which precedes the further step of introducing the gene into a specific plant. Nevertheless, it is the contribution of the inventor in the genetic field which makes it possible to take the second step and insert the gene into the genome of any appropriate plant or plant variety. Choosing a suitable plant for this purpose and arriving at a specific, marketable product, which will mostly be a plant variety, is a matter of routine breeding steps which may be rewarded by a plant breeders' right. The inventor in the genetic engineering field would not obtain appropriate protection if he were restricted to specific varieties, for two reasons: first, the development of specific varieties will often not be his field of activity and, second, he would always be limited to a few varieties even though he had provided the means for inserting the gene into all appropriate plants (European Patent Office 2000: para. 3.8).

44 European Patent Office 2000: point 3.8.

45 European Patent Office 2000: point 3.1.

46 Of course this degree can be almost negligible; many contracts stipulate a maximum degree of 0.1 per cent, but the distinction is necessarily one of degree.

47 As a result, the form of the transformation event 'denatures' the distinction between the grown and the made. It materialises the difference between these terms into a singular trace - a molecular junction - which then marks (to a different degree) both sides of the distinction between GMO and non-GMO products. The distinction is turned into a unity and then divided again in such a way as to eclipse the terms that were originally unified.

48 Lezaun 2006, 510.

49 So 'two apparently identical GMOs, identical organisms sharing the same set of transgenic elements could still be differentiated at the level of the transformation event' (Lezaun 2006: 510).

50 EH92-527-1 is the transformation event that characterises the BASF Amflora potato, whose unique identifier is BPS-25271-9.

51 The Amflora potato offers a good example; the object of the genetic modification is to produce only that starch (amylopectin) which is optimal for the production of paper and textiles. Critics of the decision to authorise cultivation of the Amflora potato (notably the parliament of Austria and the government of Italy) objected that the dissemination of the potato might weaken the efficacy of certain antibiotics.

52 As Lezaun 2006 points out, the form of the transformation event presupposes and precipitates from the coupling of a number of discursive and non-discursive practices: "the level of specificity of the "transformation event" must be understood as the intersection of multiple legal and technical trajectories, rather than as a quality intrinsic to the unit of regulation, or to the analytical tools capable of detecting it'.

53 Interview with Piet Schenkelaars, Transcontainer 2007a.

54 See generally European Commission 2009: para. 7.

55 See European Commission 2009: para. 7.2.

56 Transcontainer 2007a: 5.

57 Beckmann et al. 2006.

58 European Commission 2009.

59 Consmüller et al. 2009: 49.

60 Consmüller et al. 2009: 49.

61 For example, one might distinguish between 'actual' gene flow and 'potential' gene flow, or rates of deposition of pollen and rates of fertilisation (see Ceddia et al. 2007: 171). 
62 Beckmann et al. 2006.

63 Transcontainer 2007a.

64 Demont et al. 2008: 2.

65 Skevas et al. 2009: 60.

66 Demont et al. 2008: 3.

67 European Commission 2003a: 46.

68 European Commission 2009.

69 For a summary see Transcontainer 2007a: 3.

70 With respect to spatial segregation distances, refer to the fact that an ecology measure might be increased to reflect a 'political safety factor' (Demont et al. 2008: 12).

71 Latour 2004: 13.

\section{Bibliography}

Beckmann, Volker, Claudio Soregaroli and Justus Wesseler, 'Governing the Coexistence of GM Crops: Ex-ante Regulation and Ex-post Liability under Uncertainty and Irreversibility', Discussion Paper 1206, Institutional Change in Agriculture and Natural Resources (ICAR), Division of Resource Economics, Department of Agricultural Economics and Social Sciences, Humboldt University Berlin, 2006.

CBD (Convention on Biological Diversity), Subsidiary Body on Scientific, Technical and Technological Advice, Consequences of the Use of the New Technology for the Control of Plant Gene Expression for the Conservation and Sustainable Use of Biological Diversity, UNEP/CBD/SBSTTA/4/9/Rev. 1, 1999.

Ceddia, M. Graziano, Mark Bartlett and Charles Perrings, 'Landscape gene flow, coexistence and threshold effect: the case of genetically modified herbicide tolerant oilseed rape (Brassica napus)' (2007) 205 Ecological Modelling, 169-80.

Consmüller, Nicola, Volker Beckmann and Christian Schleyer, 'The role of coordination and cooperation in early adoption of GM crops: the case of $\mathrm{Bt}$ maize in Brandenburg, Germany' (2009) 12910 AgBioForum, 47-59.

Deleuze, G., 'Postscriptum sur les sociétés de contrôle', http://1libertaire.free.fr/ DeleuzePostScriptum.html, 1990.

Demont, M. et al., 'Are EU spatial ex ante coexistence regulations proportional?' Twelfth Congress of the European Association of Agricultural Economists, 2008.

Directive 2001/18/EC of the European Parliament and of the Council on the deliberate release into the environment of genetically modified organisms and repealing Council Directive 90/220/EEC.

ETC Group 2007.

European Commission, Report on the Implementation of National Measures on the Coexistence of Genetically Modified Crops with Conventional and Organic Farming, COM (206) 104 final, 2006.

European Commission see generally Report from the Commission to the Council and the European Parliament on the Coexistence of Genetically Modified Crops with Conventional and Organic Farming (SEK 2009).

European Patent Office, Transgenic plant/Novartis, Decision of the Enlarged Board of Appeal dated 20 December 1999, G 1/98, OJ EPO 2000, 111, 2000.

European Union, Regulation (EC) No. 178/2002 of the European Parliament and of the Council of 28 January 2002 laying down the general principles and requirements of food law, establishing the European Food Safety Authority and laying down procedures in matters of food safety, 2002. 
European Union, Commission Recommendation, Guidelines for the Development of National Strategies and Best Practices to Ensure the Coexistence of Genetically Modified (GM) Crops with Conventional and Organic Farming C, Official Journal of the European Communities, L189, 36-47, 2003 a.

European Union, Regulation (EC) No 1830/2003 of the European Parliament and of the Council of 22 September 2003 concerning the traceability and labelling of genetically modified organisms and the traceability of food and feed products produced from genetically modified organisms and amending Directive 2001/18/EC, 2003b.

Habermas, J., The Future of Human Nature, Cambridge: Polity Press, 2003.

Hills, Melissa J., Linda Hall, Paul G. Arnison and Allen Good, 'Genetic use restriction technologies (GURTs): strategies to impede transgene movement', Trends in Plant Science 12, 4 (2007), 177-83. Supplementary materials at DOI 10.1016/j. tplants, 2 February 2002.

Keenan, R. J. and Stemmer, W. P. C., 'Nontransgenic crops from transgenic plants', Nature Biotechnology 20 (2002): 215.

Latour, B., 'Matters of fact' in Making Things Public, ed. Latour, B. and Weiber, W., Cambridge MA: MIT Press, 2004.

Latour, B. and Vincent Antonin Lépinay, L'Economie : science des intérêts passionés, Paris: La Découverte, 2008.

Lezaun, J., 'Creating a new object of government: making genetically modified organisms traceable', 36 Social Studies of Science 4, 499-531, 2006.

Luhmann, N., Ecological Communication, Cambridge: Polity Press, 1989.

Luhmann, N., Social Systems, Stanford CA: Stanford University Press, 1995.

Messean, A., F. Angevin, M. Gomez-Barbero, K. Menrad and E. Rodriguez Cerezo, 'New Case Studies on the Coexistence of GM and non-GM Crops in European Agriculture', Technical Report EUR 22102 EN, http://ftp.jrc.es/EURdoc/22102ExeSumm.pdf, 2006.

Rajchman, J., Constructions, Cambridge MA: MIT Press, 1998.

Skevas, T., Wesseler, J. and Feveiro, P., 'Coping with ex-ante regulations for planting Bt maize: the Portuguese experience', 12 AgBioForum 1, 60-69, 2009.

Swanson, T. and Goeschl, T., 'Diffusion and distribution: the impacts on poor countries of technological enforcement within the biotechnology sector', in International Public Goods and Transfer of Technology under a Globalized Intellectual Property Regime, ed. K. E. Maskus and J. H. Reichmann, Cambridge: Cambridge University Press, 2005, pp. 669-94.

Transcontainer, report of workshop for coexistence regulators and advisers, 18 April $2007 \mathrm{a}$. Transcontainer, 'Transcontainer's reply to the ETC Group communiqué', 26 June 2007b. Van Dooren, T., 'Terminated seed: death, proprietary kinship and the production of (bio)wealth', 16 Science as Culture 1, 71-94, 2007.

Winner, L., 'Do artifacts have politics?' 109 Daedalus 1, 121-36, 1980. 


\section{Perspectives on environmental law and the law relating to sustainability}

A continuing role for ecofeminism?

\section{Karen Morrow}

\section{I Introduction}

Diversity is, in many ways, the basis of women's politics and the politics of ecology; gender politics is largely the politics of difference. Eco-politics, too, is based on nature's variety and difference. ...

Due in part to these inherent qualities, ecofeminism can be understood as a significant aspect of the politics of inclusion. Ecofeminism is rooted in the dynamic and diverse social and political milieu provided by feminist and ecology movements. As such, it recognises the pervasive, complex and multifarious nature of oppression/exclusion. Sustainability too, with its emphasis on the role of bottom-up participation in governance in augmenting orthodox international practice in this area, also espouses the new inclusiveness. The foundational Brundtland Report is notable in this regard, observing that:

The law alone cannot enforce the common interest. It principally needs community knowledge and support, which entails greater public participation in the decisions that affect the environment. This is best secured by decentralizing the management of resources upon which local communities depend, and giving these communities an effective say over the use of these resources. It will also require promoting citizens' initiatives, empowering people's organizations, and strengthening local democracy. $^{2}$

While it is important to recognise that 'participation and sustainable development are both ambiguous concepts, ${ }^{3}$ the potential for productive linkage and synergistic dialogue between ecofeminism and sustainability in respect of advocating and actualising more inclusive approaches to environmental decision-making is clearly worthy of further examination.

Realising the full potential of inclusive approaches to decision-making requires not only social and political change but also ultimately institutional and legislative innovation in order to address the manifest inequalities that 
exclude certain voices from participation and power in the current polity, to the detriment of (amongst other things) sustainability. Discussion here will focus on the continuing relevance of ecofeminism and related approaches (specifically Lorraine Code's concept of 'ecological thinking') in promoting debate in their specific spheres and in making a potentially significant contribution to a more inclusive political (and emerging legal) praxis in the sphere of sustainability. Particular emphasis will be placed on the contribution of inclusive ecofeminist approaches to developing more sustainable decision-making processes, specifically through advocating an expanded view of viable inputs into both discursive and deliberative systems. This discussion builds on the broad approach towards valid participation that is already evident in environmental sociology, ${ }^{4}$ and considers its ripeness for extension into the legal sphere.

\subsection{Sustainability and the new inclusiveness}

The principles that may be regarded as supporting sustainability, while not uncontroversial in themselves, ${ }^{5}$ are, to a degree, the product of the interplay between global governance and increased awareness and scientific understanding of the now potentially perilous impact of human activity on the biosphere across a range of functions, such as pollution, resource scarcity, loss of biodiversity and global warming. At the same time, moral, political and legal imperatives have also played a substantial role in fashioning sustainability thought and action. Spurred on by the work of economists ${ }^{6}$ and scientists $^{7}$ in particular, the international community sought to initiate change, ${ }^{8}$ notably through setting up the World Commission on Environment and Development (WCED) to investigate sustainability. The WCED initiated a global consultation process (in itself exhibiting the new inclusiveness), culminating in the report Our Common Future. ${ }^{9}$ The report posited the need for, what would in social, economic, environmental and, not least, political terms ${ }^{10}$ constitute a radical change in the way humanity interacts with the environment. However, underpinning the headlining (and indeed headline-grabbing) concept of sustainable development ${ }^{11}$ invoked by the Brundtland Report, lies the fundamental recognition that, to achieve sustainable development, the international community would need to alter not only the ways in which humanity relates to the environment but also the ways in which people relate to one another. To fully achieve this would require a fundamental re-visioning of prevailing concepts and systems of governance.

The viability of sustainable development as presented in the Brundtland Report is based in part on the concept of sustainable governance, which looks wider than the traditionally empowered categories of political actor in order to incorporate all stakeholders in a process that is as much, if not more, about growing sustainability up from grass-roots level as it is about attempting to promote it from above: 
We call for a common endeavour and for new norms of behaviour at all levels and in the interests of all. The changes in attitudes, in social values, and in aspirations that the report urges will depend on vast campaigns of education, debate and public participation.

To this end, we appeal to citizens' groups, to non-governmental organizations, to educational institutions, and to the scientific community. They have all played indispensable roles in the creation of public awareness and political change in the past. They will play a crucial part in putting the world on to sustainable development paths, in laying the groundwork for Our Common Future. ${ }^{12}$

The Commission's own methodology showed a commitment to wide participation in terms of information gathering process: notably, its deliberations were informed by the innovative use of public hearings dispersed across the globe to elicit information from a broad range of stakeholders. ${ }^{13}$ The need for governance reform to give voice to those normally excluded for decisionmaking processes is clearly articulated in the report:

It could be argued that the distribution of power and influence within society lies at the heart of most environment and development challenges. Hence new approaches must involve programmes of social development, particularly to improve the position of women in society, to protect vulnerable groups, and to promote local participation in decision-making. ${ }^{14}$

Concepts of intergenerational and intra-generational equity are also pressed into service to underpin the need for an inclusive approach to decision-making:

Even the narrow notion of physical sustainability implies a concern for social equity between generations, a concern that must logically be extended to equity within each generation. ${ }^{15}$

While the intergenerational equity issues are philosophically fraught with (perhaps insurmountable) difficulties which tend to preoccupy the academy, the more immediate issues of intra-generational justice merit just as close attention, since: ' ... many problems of resource depletion and environmental stress arise from disparities in economic and political power'. ${ }^{16}$ In this context, the fact that the WCED identified: '... a political system that secures effective citizen participation in decision-making' ${ }^{17}$ as the first plank in the strategy for pursuing sustainable development seems particularly apposite. The Commission recognised that the contribution of NGO networking and other activities to sustainability praxis was already significant and growing even at this stage. ${ }^{18}$ In light of this, the report went so far as to 
advocate a role for law in securing formal participation and supporting rights for NGOs as a core concern:

Recognition by states of their responsibility to ensure an adequate environment for present as well as future generations is an important step towards sustainable development. However, progress will also be facilitated by recognition of, for example, the right of individuals to know and have access to current information on the state of the environment and natural resources, the right to be consulted and to participate in decision-making on activities likely to have a significant effect on the environment, and the right to legal remedies and redress for those whose health or environment has been or may be seriously affected. ${ }^{19}$

While the Brundtland Report enthusiastically embraces the notion of an extremely prominent role for NGOs in progressing the sustainability agenda as an unalloyed good, a note of caution must be sounded: there is a danger that NGOs come to be seen, and to see themselves as acting, as a form of proxy for the public in terms of participation. This raises issues of the viability of NGOs' credentials in this regard, not least their ability to be representative of the public. Furthermore, over-reliance on NGO participation also raises the possibility of the public delegating both responsibility and activism to professional NGOs. These factors combine to leave little space for direct citizen involvement in decision-making processes. ${ }^{20}$ However, in particular where international law is concerned, but also, arguably given the complexity of environmental decision-making contexts, in the domestic sphere, it may be the case that, for most citizens, meaningful participation is beyond their grasp without the mediation and assistance of NGOs. In any event, post-Brundtland, the participation issue quickly became pressing, in particular in light of the crucial role played by environmental concerns in spurring the UN to action on sustainability in the UNCED in Rio in 1992.

The ongoing work of the Commission for Sustainable Development (CSD) in its appointed task of fostering the development of Agenda 21 has played an important part, in principle at least in opening up governance in light of the sustainability imperative. It was only, however, at the World Summit on Sustainable Development (WSSD) in Johannesburg in 2002 that the sustainable governance agenda really came to the fore in the international community. The WSSD, in contrast to Rio, which was arguably dominated by NGOs, had a strong business steer ${ }^{21}$ in tandem with broader developments in this area in the popularisation and practice of Corporate Social Responsibility. One result of this was that a major theme of the summit was to develop 'partnership' approaches to governance. In so doing, it placed already powerful major groups, notably those representing business, industry, science and technology centre stage and, arguably effectively marginalised other stakeholders in terms of influence if not participation. On the 
positive side, by drawing diverse parties into a co-operative endeavour (though this may in and of itself be problematic), the practice of partnership at least attempts to harness broader participation to defuse conflict and pursue goals. It also serves to render co-operation more formal and businesslike. In any event, post-Johannesburg, civil society participation is now the norm in sustainability contexts generally and with respect to partnerships in particular. Partnership as pursued at the WSSD and beyond, while viewed on the whole as a fairly positive development (if limited by voluntarism) by some commentators, ${ }^{22}$ is seen as negative by others. ${ }^{23}$ On balance, while partnership is currently very much in vogue, it remains to be seen whether it actually offers much in the way of substantive change in the business of governance.

For all the interesting and often useful strategies adopted by the CSD in response to its ambitious and innovative remit to foster the sustainability agenda (in particular in actively involving major groups in its activities), it must be said that it remains a weak and marginal body, ${ }^{24}$ even within the UN. In any event, through developments in sustainability governance under the auspices of the CSD it has become clear that, for good or ill, the praxis of participation in governance for sustainability is, even where formal appearances remain broadly consistent, ${ }^{25}$ capable of constantly changing and evolving, often quite profoundly, over time. ${ }^{26}$

\subsection{Gender and the new inclusiveness}

The value of looking at gender-based exclusion from power and decisionmaking is not only of interest in its own right. It also offers potentially valuable insights into the participation of marginalised and excluded groups in environmental law and the sustainability praxis more generally, as, in part, the latter attempts to address a multiplicity of excluded groups including women. In addition, inter-group permeability means that, for many women, the reality of their experience in this regard is the product of multiple/compounded exclusion, making the need to address the interactions between gender and other forms of marginalisation a particularly pressing one.

At the outset, it should be noted that, despite internal differences, the women's movement had established global networks at its disposal that arguably meant it was comparatively well placed to exploit the opportunities provided by the forging of the sustainability agenda. ${ }^{27}$ This, together with a cooperative modus operandi, enabled the women's movement to develop a clear role in the new, more consensual sustainability-based governance. At the Rio Earth Summit, women's groups exploited the opportunity to influence agenda-setting provided by the more inclusive approach emerging in this area as espoused by the Brundtland Report. In particular, the women's movement was successful in promoting substantial changes to the draft of Agenda 21 (rendering the content of the formerly gender-blind working 
document gendered throughout in its final form) through the pre-UNCED work of the UN Environment Programme/Women's Environment and Development Organisation-run World Women's Congress for a Healthy Planet. Women were also included in the major groups whose participation was deemed crucial to progressing sustainability in Agenda 21. Significantly, gender also gained specific coverage in Principle 20 of the Rio Declaration. In principle, subsequent UN initiatives such as the Beijing Platform of Action $^{28}$ and the Commission on the Status of Women's Agreed Conclusions on the Status of Women and the Environment ${ }^{29}$ have continued to develop the integration of gender and environmental issues, albeit often with limited practical impact. ${ }^{30}$

Underpinning the Brundtland-inspired approach adopted by Agenda 21 is the recognition that sustainability is founded on sustainable decision-making which in turn requires participation in and ownership of decisions by all stakeholders, from the major groups to the individual. A viable sustainability paradigm therefore requires a shift in the locus of action far beyond traditional state actors and the privileged cohorts that comprise the establishment in the development of international law and policy. Inclusiveness is particularly important here, as women are under-represented in these contexts, and as a result the established role of women in respect of the environment often imposes responsibility without power. If, as argued by the Brundtland Report, the success of sustainability depends on grass-roots change, this is not a viable prospect in the absence of empowerment of those who are expected to deliver on this - many of whom are women. ${ }^{31}$ Law, of course, has a role to play in addressing these issues. However, even when well intentioned (which is not always the case), the law can unintentionally aggravate adverse gender impacts in the environmental sphere. ${ }^{32}$ Still, sustainability demands sustainable outcomes, and to achieve this, decisions must be arrived at in a sustainable way, i.e. through sustainable processes produced by sustainable institutions; law must therefore be pressed into service to concrete effect in this regard.

In the past, strategies for tackling gender issues tended to focus on achieving gender neutrality as the solution. More recent thinking indicated that this may not be the answer and that better results on the ground could be achieved, first by developing policies focused on women, ${ }^{33}$ and to a greater degree by adopting the more thoroughgoing gender awareness espoused by what has become known as 'gender mainstreaming'. Gender mainstreaming represents a third generation of gender policy (after 'in principle' recognition and 'women's issues' phases). Like sustainability, gender mainstreaming necessarily requires the adoption of an integrationist approach to developing law and policy. Gender mainstreaming had its practical origins in the failures and limitations of first and second generation policies on women. Its theoretical basis, on the other hand, can be found in the UN's 1995 Beijing Conference on Women, and in a more developed fashion, in the 
Beijing Plus-five Conference, Women 2000: Gender, Equality, Development and Peace for the Twenty-first Century. The 'in principle' commitment at such a high policy level was followed up by the introduction of System-wide Plans for the Advancement of Women and by a whole raft of internal guidance and training across the UN. A useful working definition of gender mainstreaming has been provided by the UN Economic and Social Council, which characterises it as:

... the process of assessing the implications for women and men of any planned action, including legislation, policies or programmes, in all areas and at all levels. It is a strategy for making women's as well as men's concerns and experiences an integral dimension of the design, implementation, monitoring and evaluation of policies and programmes in all political, economic and societal spheres so that women and men benefit equally and inequality is not perpetuated. The ultimate goal is to achieve gender equality. ${ }^{34}$

The Council of Europe offers an alternative version comprising:

a gender equality strategy that aims to transform organizational processes and practices by eliminating gender biases in existing routines, involving the regular actors in this transformation process. ${ }^{35}$

Despite cosmetic differences, both definitions share the same basic aim of gender equality. While each encapsulates practically focused initiatives, they are both also geared (implicitly in the case of ECOSOC and explicitly in that of the Council of Europe) to the more profound issue of changing organisational culture.

The central problem is that, while the principles of both gender equality and sustainability may be fairly broadly accepted, principles do not make prescriptions. In both cases, realising these fairly abstract goods in practical terms is fraught with disagreement and difficulty, amplified by the additional complexity arising from the overlap between gender and sustainability. The OECD has taken an in-depth look at the relationship between gender and sustainable development ${ }^{36}$ as part both of its Horizontal Programme on Sustainable Development, and its contribution to the ongoing work of the CSD in this area. The OECD's approach tackling cross-cutting issues in this area is to 'engender' its analytical, statistical and policy work ${ }^{37}$ in order to improve its policies and foster more sustainable development. Its focus tends to be on immediate practical concerns such as health and education, though it also recognises that the societal substructure, including political participation and legal rights, also need to be addressed. This is commendable in real terms, as bodies tend to respond more effectively to concerns that can be addressed in practical terms rather than to more profound needs for change 
in organisational culture. ${ }^{38}$ At the same time, this focus can be rather reductionist: there is a very real danger that a goal-setting and a tick-box-approach focus can become somewhat myopic. While intuitively appealing to a degree and arguably capable of solving some problems in isolation, the 'practical' approach can ultimately miss the underlying point and avoid the major issues that are the cause of the symptoms tackled.

\subsection{Ecofeminism and sustainability}

Karen Warren, a leading scholar in the field, describes ecofeminism as providing multicultural (on social domination in its many and varied forms) and pluralist perspectives ${ }^{39}$ on:

... a variety of so-called 'women-nature connections' - historical, empirical, conceptual religious, literary, political, ethical, epistemological, methodological and theoretical connections on how one treats women and the earth. ${ }^{40}$

Warren further characterises the ecofeminist perspective as twofold: identifying and tackling patriarchy, but also developing 'practices, policies and theories which are not male-gender biased', and which recognise the role of humans as 'ecological beings'. ${ }^{41}$ It is in the latter elements that a great deal of potential common ground may be found with the sphere of sustainable governance, in so far as the experience of some of the major groups identified in Agenda 21, labouring under what Slicer terms 'related multiple social oppressions', is concerned. ${ }^{42}$

In its early years, ecofeminism was somewhat unfairly criticised as narrowly ecologically focused and simplistic. This has not, however, been borne out by its subsequent rapid growth in both range and sophistication..$^{43}$ Ecofeminism was also rather more justifiably criticised for being dominated by white Western theorists. ${ }^{44}$ Comparatively soon, however, it developed a more dispersed character, through distinctive and influential contributions by women of colour and the developing world. ${ }^{45}$ Drawing on its own rhetoric of inclusiveness, therefore, ${ }^{46}$ ecofeminism ${ }^{47}$ is now best understood as a very broad church indeed. At the same time, ecofeminism is recognised as a multifaceted and contested area of discourse. This does not, however, decrease its salience. In fact, its fluid and dynamic nature is one of its strengths. ${ }^{48}$ The same may be said for ecological discourse, which is also neither unified nor unifying, but conflicted and unstable, and consequently creative and vibrant. ${ }^{49}$ Such 'creative conflict' perspectives draw to some degree on work such as that of Ferguson on identity politics and as a result identify the difficulty or desirability of defining a 'collective' or 'community'. Both ecological and ecofeminist discourses do seem capable of accommodating the inevitable contestation of the nature of such 'commonalities' and this does 
not in and of itself render them otiose for practical purposes ${ }^{50}$ and may actually enable them to thrive. Ferguson in turn builds on Zerilli's work, ${ }^{51}$ making the point, highly relevant when considering the strong activist component of ecofeminism, that, in many respects, practice and participation are more important than identity claims in defining commonality. ${ }^{52}$ The inclusiveness of such practice/participation-based views of identity is further enhanced (if also to a degree problematised) by the fact that identities are necessarily the complex product of 'multiple, overlapping and sometimes competing practices'. ${ }^{53}$ It should therefore be noted that attempts to describe them on the basis of class membership will always sacrifice accuracy to simplicity.

In addition to the advantages offered by a practice/participation based approach, ecofeminism's expansive philosophical, social, political and economic foundations include both activist and philosophical practice in its form and content. This ensures that ecofeminism offers a range of different but related lenses through which to view environmental issues in general and environmental decision-making in particular. The many voices that have emerged in the development and maturation of ecofeminism have played significant (if not entirely compatible) roles and have, at the very least, led it to become a vibrant, sustained and dynamic part of social and political discourse. It is therefore to be hoped that it will also become part of a legal landscape, especially in relation to inclusiveness in the context of sustainability. This aspiration sits well with Sandilands' identification of ecofeminism's greatest potential as:

... the democratic politicisation of gender and nature ... challenging hegemonic identifications, ... [and] opening up new spaces of social and political (and ecological) life to scrutiny and debate and of tackling the discursive relations in which problematic gendered and ecological relations are embedded. ${ }^{54}$

In light of this, ecofeminism has already made important contributions in a broader theoretical context, not least in its contribution to feminist political ecology, which regards gender as a 'critical variable' in human interaction with the environment ${ }^{55}$ and sees 'gendered knowledges and spaces and women's collective struggles' as central ${ }^{56}$ to the realisation of sustainable political and ecological practices. Its potential to make a broader contribution to further developing the theory and practice of sustainability and the law that supports it is clear.

\subsection{Considering Code's ecological thinking}

According to some commentators, despite a raft of gender initiatives in a variety of fields, while: 
... there has been a lot of dialogue on the intrinsic link between citizenship and environmental issues or feminism ... there has never been an attempt to link the two to derive the complex political connection. ${ }^{57}$

This is arguably too dismissive of the existing working theories of ecofeminism, despite the fact that practical progress has thus far been rather limited. As things stand, arguably the most interesting developments in ecofeminism in terms of its contribution to broader debate and its ability to forge new connections and inclusiveness, lie in its contribution to feminist philosophy. Lorraine Code's work in this area is of particular interest. Building on clear ecofeminist foundations, she has developed her earlier work on gender, considering feminist epistemology in the context of broader axes of oppression, ${ }^{58}$ into a concept which she terms 'ecological thinking' ${ }^{59}$ She defines the latter as:

... not simply thinking about ecology or about the environment: it generates a revisioned mode of engagement with knowledge, subjectivity, politics, ethics, science, citizenship and agency. ... ${ }^{60}$

Thus defined, ecological thinking provides an interesting and even revolutionary perspective from which to ponder the need to alter political and legal theory and practice in order to meet the challenges posed by a biosphere compromised by human activity. Despite superficial appearances and explicit acknowledgement of Rachel Carson ${ }^{61}$ and other environmental scientists' work, Code's approach is not a work of traditional ecology. Rather, it seeks to draw on the methodologies, currency and indeed ubiquity of ecology in modern life and thought to inform a broader approach to societal ordering. This fits well with Koggel's broader observation that: 'epistemological, moral and political projects are intertwined'. ${ }^{62}$

Code's concept of ecological thinking responds to this challenge in a number of ways. First, by consciously promoting the development of more inclusive forms of decision-making - advocating what she terms "collaborative epistemic negotiation' ${ }^{63}$ This negotiative process provides the means whereby 'knowledge claims' become adopted in environmental policy', ${ }^{64}$ and looks at policy debate as a heuristic device to take such claims from contested to accredited, effectively democratising this process. Given the situated and embodied nature of our relationship to the world around us, the case for adopting the new inclusiveness and arriving at what Jasanoff terms 'co-production' of knowledge and policy ${ }^{65}$ in this context is particularly marked. Code's approach also ties in convincingly with the 'pivotal' ${ }^{66}$ Foucauldian perspective that views power-based approaches to societal ordering as inadequate to take into account the 'diffused nature of control' in modern society ${ }^{67}$ and postulates by way of remedy the adoption of a discursive element in attempts to address such concerns. As Ockwell and Rydin succinctly express it: 
Foucault highlights the regulatory power of discourses as they act to select appropriate and meaningful utterances and actions within a struggle for hegemony in the policy-making process. $^{68}$

Hajer applies a 'post-Foucauldian framework', ${ }^{69}$ adapting this analysis in an environmental context and arguing that a discursive approach is particularly well suited to deal with the conflict situations that arise therein. Ockwell and Rydin's comments on Hajer's work are useful:

... discourses are the product of institutional practices and individual activities that reflect particular types of knowledge. They are produced actively through human agencies that undertake certain practices and describe the world in certain ways. Actors do not, however, act within a vacuum. Discourses simultaneously have structuring capabilities as they provide parameters within which people act and shape the way actors influence the world around them. ${ }^{70}$

They particularly admire Hajer's 'story-line' approach to discursive solutions for conflict, as both combining different threads into a narrative and proving an evaluative context for contested claims:

... story-lines also play an essential role in positioning actors, adding credence to the claims of certain groups and rendering those of other groups less credible. ${ }^{71}$

In terms of processing knowledge claims, sociology has shown in particular over the last part of the twentieth century, ${ }^{72}$ that ${ }^{6} \ldots$ knowledge is socially constructed and shaped by the institutional contexts within which it is generated and accredited' ${ }^{73}$ In response to such an understanding, inclusiveness plays a particularly significant role in Code's approach, in terms of process and by actively seeking to address the multiple foci of institutional exclusion including: gender and sex, race, class, and postcolonialism and draw these perspectives into established policy and decision-making processes. The goal here is not, however, limited to pursuing inclusiveness but also in part to adapting, enriching and expanding societal engagement with knowledge claims in the development of more equitable but also crucially more effective praxis. ${ }^{74}$

In consequence, Code regards the realisation of ecological thinking as requiring:

... a revisioned mode of engagement with knowledge, subjectivity, politics, ethics, science, citizenship, and agency that pervades and reconfigures theory and practice. ${ }^{75}$ 
As a result, ecological thinking aspires to actualising the new inclusiveness through developing a more holistic and less compartmentalised approach to decision-making. The aim of ecological thinking in this regard is far-reaching, seeking not only to tackle atomisation but also to replace attempts to address it by mere synthesis, that represent the current norm, with a much more ambitious holism. ${ }^{76}$ Still, as Læssøe rightly states, primacy of place arguably needs to be assigned to professional (scientific and technical) knowledge because:

... the complicated problems related to technological development and the associated environmental implications grant experts and technocrats considerable power to influence political decisions that have major consequences for the lives of ordinary citizens. ${ }^{77}$

This, however, cannot tell the whole story. It is increasingly accepted that knowledge claims are contested. ${ }^{78}$ Some disciplines, notably environmental sociology, are disposed to engage head-on with the concept of contested knowledge; in particular recognising the "... shortcomings of abstracted and "neutral" scientific knowledge in dealing with complex, uncertain, and deeply value-laden environmental questions'. ${ }^{79}$ On the other hand, where the law is concerned, 'objectivity' is often used to justify technocracy ${ }^{80}$ and an almost blind faith in science. This is not to say that the contestability of knowledge is not discussed: Steele, for example, sees value in carefully considering dissenting views ' ... particularly in an area where there are many uncertainties'. To this end, this discussion will focus on the potentially discourse transforming integration of what is often, arguably somewhat unhelpfully, termed 'situated knowledge'81 (all knowledge is, after all situated in some way) into institutional understanding. Steele identifies a number of the potential benefits of such knowledge as including, in some cases, where it is generated by affected parties, offering 'greater understanding' of the issues involved. In the alternative, knowledge contributed by interested parties enjoying broader cogent experience can offer the 'bread of reflection'. ${ }^{82}$

It is unsurprising therefore that Code strongly critiques what may be termed the prevailing super-dominance of professionalism in decision-making processes and the consequent erosion of public trust in both the procedures and their outcomes that is one of its most corrosive results. Code's approach in this area complements the work of sociological theorists such as Beck. ${ }^{83}$ Much of her emphasis lies in examining the customary (though increasingly questioned $^{84}$ ) dominance and almost talismanic invocation of science as justification in current decision-making processes and the characterisation of scientific knowledge as ' ... the most objective, certain, and sophisticated knowledge humankind has achieved ... , ${ }^{85}$ As a result, she sees the scientific community and their claims enjoying enormous (and not always warranted) epistemic authority and creditability. ${ }^{86}$ The growth of 
constructionist analysis ${ }^{87}$ of science is a significant consideration in this regard, arguing that:

Science is 'just' a contingent and historical culture or form of life - a communal and local language game without any privileged access to objectivity and truth. Scientific knowledge is 'constructed' much like other knowledge; it is local and contextual, maybe 'gendered' and politically suspect. ${ }^{88}$

According to this view, scientific knowledge, far from being able to support special claims to objectivity, precision and validity, is in at least some respects, as indeterminate and shaped by cultural factors as lay knowledge. ${ }^{89}$ In light of such observations, Code regards continued unquestioning acceptance of the super-dominance of science and its claims as dangerously combining to mask hidden influences, interests and agendas.

Code's analysis of the influence of science in decision-making could (and indeed arguably should) just as cogently be applied to that of professional politicians and administrators, whose own expertise and resultant authority is just as entrenched in processes and practices as that of the scientific community. The dominance of the political, scientific and ultimately economic establishment in decision-making appears to remain the case despite ostensible efforts to embrace the new inclusiveness. This is demonstrated in Pesendorfer's work on the legal control regulation of chemicals in the EU. He views regulation in this area as traditionally based on 'hard scientific facts' ${ }^{90}$ Pesendorfer observes that, despite a move on paper towards incorporating more inclusive approaches to regulatory issues in this sphere under the REACH reforms, outcomes offer little change 'business as usual'. In arriving at this conclusion, Pesendorfer identifies a number of factors that contribute to this situation, namely:

... structural factors (institutional arrangements, power of industry), the broader context (... world trade, neo-liberal globalisation, Lisbon goals) and the dominant belief system (paradigm) shared by the major actors lessen ambitious goals and that new modes of (participatory) governance have an impact on only the debate, not the output and outcome. ${ }^{91}$

Pesendorfer views the REACH regulation as ultimately being characterised by a series of ongoing conflicts between what he terms 'advocacy coalitions'. ${ }^{92}$ Despite the apparent opening up of the regulatory process, the vast power, resource and influence differentials between the 'business coalition' on the one hand and the 'Green coalition' on the other had a huge impact on the end result, ${ }^{93}$ and the locus of debate and decision were shifted from the environmental to the economic sphere. The new inclusiveness may have given the green coalition an opportunity to participate in the regulatory 
decision-making process. It did not, however, ensure that it would exert actual influence on outcomes. ${ }^{94}$ This calls into question the viability of inclusive/participatory governance. The value of the new inclusiveness is not confined to participation for its own sake (though this is beneficial in the processes of sustainable governance) but includes the broadening of the range of inputs into regulatory decision-making to render regulatory outcomes themselves more sustainable. Pesendorfer's analysis of the operation of REACH demonstrates a degree of intractability in the face of attempts to reform regulation and embrace inclusiveness that is arguably equally applicable to the broader environmental regulatory milieu and gives rise to profound cause for concern.

In response to the continuing dominance of such privileged classes of knowledge, ecological thinking invokes the application of a more dispersed methodology for decision-making, advocating a horizontal and integrated rather than a vertical and segregated, approach to knowledge gathering and decisionmaking. The task of the new inclusiveness is to admit knowledge to both counter and complement the 'dominant social-political imaginaries' of the machinery of the scientific and political/administrative communities. ${ }^{95}$ This requires the development of a more catholic approach to information gathering and knowledge generation; one that allows commensurate value to be placed on 'local, lay, experiential and intuitive' ${ }^{96}$ knowledge in addition to materials from the professional realm. In light of such concerns, Steele underlines the importance of complementary knowledge in the following terms:

Scientific claims are increasingly debated in the public realm, and citizens are supposedly more able to gain access to information on the basis of which knowledge-claims can be asserted and questioned. It has been argued that civil society is thus increasingly well informed, and citizens increasingly aware that the claims of science are disputable ... One suggestion here is that the public through its scepticism and willingness to question scientific claims, may provide important decision-making resources in respect of information, where those with responsibility for decisions choose to recognize this. ${ }^{97}$

One possible response to this issue is to advocate with Irwin the development of "citizen science" 98 in order to broaden what are regarded as cogent knowledge claims. This, however, brings unwelcome conceptual baggage and arguably requires the excluded to ape the form of the mainstream as a prerequisite for inclusion. A preferable term, therefore, would be quotidian epistemology. Quotidian epistemology encapsulates understanding based on lived experience, generating, to borrow Code's analysis, knowledge that is '... part of and specifically located in a social-physical world that constrains and enables human practices'. ${ }^{99}$ Quotidian epistemology by its very nature encapsulates spatial knowledge, recognising that: 
Place matters because without a recognition of and attachment to places, we cannot defend the environment, we cannot feel a struggle, we cannot fight for anything [Nonetheless] ... we need to recognise the different ways and the different places that we are attached to. They are not all natural. ${ }^{100}$

But at the same time it extends to embrace all other dimensions of experientially acquired or lived knowledge.

The concept of quotidian epistemology shares some features of Lyotard's 'narrative knowledge', ${ }^{101}$ not least in adopting an expansive approach to knowledge itself, founded on the recognition that 'it coincides with an extensive array of competence-building measures' ${ }^{102}$ Both suggest a pluralistic approach that is helpful in addressing the significant 'blind spot' in science-dominated decision-making processes. ${ }^{103}$ Furthermore, both approaches underline the distinction between knowledge and learning, identifying science as a (limited) subset of the latter. Lyotard acknowledges the specific limitations of scientific knowledge in its reliance on experiment-based verification, and more significantly for present purposes, also notes that the validity of its claims depends on its expression in 'the language judged relevant by the experts'. ${ }^{104}$ In considering scientific and non-scientific (in his approach narrative) knowledge, while Lyotard regards the two as essentially incommensurable, he acknowledges the variable influence that they exert on one another; more significantly, he views 'the former's existence as no more - and no less - necessary than the latter's'. ${ }^{105}$

Quotidian epistemology is however distinguishable from Lyotard's narrative knowledge in that it is not to be equated with custom or the self-legitimating narrative as its quintessential form. Rather, it is based on observation and experience and therefore claims a type of evidence-based validity, though not one determined by the strict scientific canon. More broadly evidenced experiential claims of this type have a long-established pedigree in the law and quotidian epistemology therefore owes its validity to a spatially located and experienced understanding of a lived environment rather than to status accorded to it as quasi-customary knowledge. Furthermore the value of quotidian epistemology lies in adding a significant additional dimension to evidence-based argument in contested decisions. In this regard, quotidian epistemology ultimately seeks to augment and more effectively socially locate technical understanding by adopting a broader approach to decision-making. This is founded on integrating additional available and useful multiple knowledges that are generated by attested lived experience into the realm of legitimate and indeed necessary consideration. Quotidian epistemology aims to draw on the full richness and resource of experience in additionally informing decisionmaking processes and outcomes to achieve multi-dimensional and therefore optimal consideration of the mandated actions that result. That quotidian knowledge is inherently and necessarily diverse in nature as a result is not a weakness, but part of its value and utility. Code's ecological thinking, 
focusing, as it does, on details, difference and their significance, rather than on trying to bluntly fit everything to a 'one size fits all' prescription, is exceptionally well geared to promote, value and exploit quotidian knowledge. This mutually supportive accommodation is further bolstered by the emphasis within ecological thinking on dealing with what Code terms 'evidential analogies and disanalogies', which

... combines careful readings of evidence characteristic of empiricism in its creative, deliberative versions with investigations that locate events, experiences, symptoms, social issues, problems within wider patterns of power and privilege, oppression and victimization, scarcity and plenty, joy and sorrow. ${ }^{106}$

While quotidian knowledge is tied to embodied experience and necessarily flexible in nature, Code argues that it is not thereby reduced to the merely relativistic but rather "... it is sufficiently coherent to be interpreted and enacted across widely diverse situations' ${ }^{107}$ This is in part due to the fact that Code views knowledge as the product of a collective and 'deliberative process of negotiation', ${ }^{108}$ which is necessarily reflexive and iterative in nature but also grounded in physical and historical reality and that as a result, both the contested process of negotiating knowledge, and the constraints imposed by reality, prevent a descent into what Saarikoski terms the 'abyss of relativism'. ${ }^{109}$ Koggel's analysis of ecological thinking is helpful here. Koggel recognises that 'knowledge is provisional, dynamic and changing' and furthermore that:

Responsible knowing emerges through engagement in and interaction with the world and through a process of critical reflexivity about the role of humans and of the environment in shaping communities, ecosystems and the world as a whole. ${ }^{110}$

Nonetheless, social constructivism rightly suggests, quotidian knowledge should be just as open to testing and evaluation as any other type of knowledge claim: its validity, cogency and relevance are not to be accepted without question. ${ }^{111}$ This adds a new multidimensionality to the negotiation of knowledge, in terms of its construction and accreditation and to addressing conflicting knowledges. ${ }^{112}$ This will inevitably feature multifaceted conflicts along the spectra from scientific and quotidian and intra-scientific and intra-quotidian camps and also to the forging of variable alliances between them in specific contexts. Such complexity is however to be embraced rather than rejected if we are taking ecology as our model, since:

Ecosystems are inherently variable and complex, a fact often obscured by the simplicity with which environmental problems are portrayed and policy solutions prescribed. ${ }^{113}$ 
Code's approach arguably favours strategies that are very familiar to those steeped in the historic common-law case-based methodology. The broad application of legal principles (rather than specific prescriptions) on a caseby-case basis to the facts in hand, for example in the law of nuisance, necessarily produces decisions that are specifically spatially founded and located. ${ }^{114}$ The determination of disputes that are the subject of judicial consideration in this context is, in theory at least, the result of a combination of expert opinion (legal and increasingly scientific) and the quotidian (law would usually term this 'subjective') experience of claimants sufficiently resourced and motivated by experienced interference with private property rights ${ }^{115}$ to initiate proceedings. The core concept of reasonableness in nuisance, where physical damage to neighbour's property is always unreasonable and the actionability of intangible interference with a particular claimant's use and enjoyment of land is judged against broadly accepted societal standards of behaviour, has long served to accommodate individual quotidian experiences on the one hand, while preventing relativism from prevailing in the application of the law on the other. However, as the twentieth century progressed, the role of the scientific experts in this area came, as the result of judicial deference, to often (but not always) dominate decision-making. Typical of the former all too frequently manifest situation is the case of Graham and Graham v Rechem [1996] Env LR 158, at the time the second-longest civil case in English legal history, in which the claimants' evidence of the alleged impacts of the defendant's neighbouring incinerator on their own health and that of their livestock was roundly dismissed by the court. This can, however, be contrasted with the approach adopted by the court in Blackburn v ARC [1998] Env LR 469 which found the claimants' observations on the impact of a neighbouring landfill site on their property rights germane to the determination of the case. While what may be termed quotidian knowledge was utilised and valued by the courts in Blackburn ${ }^{116}$ it was done in rather qualified terms and with a limited impact on the outcome. In both instant cases, while the claimants succeeded, redress was confined to damages rather than halting the activities causing the interferences complained of.

Finally, the identification of responsibility as a key tenet of Code's theory is an important safeguard against the potential for her concept of ecological thinking to promote relativism in the generation of knowledge: central to her theory is the idea that knowledge brings with it responsibility and that this applies to all knowledge holders, both individually and collectively. Responsibility also rests with all, regardless of gender and in recognition of this, change is required to 'create an impact on collective decision-making', ${ }^{117}$ an area in which there is much to be done: as Basu puts it, 'although citizenship is supposed to be gender neutral, it is in fact an extremely gendered activity'. ${ }^{118}$ This is also true of many of the activities attached to citizenship, since the concept is necessarily status based. In response to this and the recognition that ecological concerns invoke debate on notions of responsible 
citizenship $^{119}$ and trust, substantive change is required in the practices of citizenship with massive ramifications for the way in which decisions are made:

Granting centrality to responsibility in this ecological framework affirms a pivotal role for consultative, deliberative, negotiated decisions in constructing, claiming and circulating knowledge. ${ }^{120}$

The fact that Code's concept of ecological thinking is so clearly predicated on an understanding of the complexity and interconnections that characterise society is absolutely crucial to its construction. These features form part of a wider project geared towards what Code terms 'ideal cohabitation' ${ }^{121}$ in respect of both the human and the natural world in a more viable and just society. Furthermore, Code sees a significant virtue of ecological thinking as providing the impetus to 'reconsider the power and value of the small', ${ }^{122}$ an approach that fits well in principle with, for example, the 'best practice' approach adopted towards sustainability by the UN's Commission for Sustainable Development (CSD), considered above. Even so, Code is nervous of equating the global with the local, fearing that to do so ' ... posits an illusory symmetry between the two'. ${ }^{123}$ While this concern may be justified in some respects, for example in that what is local is knowable in a way that what is global is not, it should not be allowed to mask the fact that significant commonalities do exist in the many locals that together make up the global in any given context and that there is a great deal to be said for dialogue and dissemination of experience between them. Indeed Code herself sees the value of the power of experience of the particular to 'generate analogies', ${ }^{124}$ though not, by conscious vigilance for disanalogies, prescriptions that are more broadly applicable.

Taken as a whole, ecological thinking is far removed from the often largely cosmetic changes to political praxis suggested by a grafting on of sustainability to business as usual models. Its realisation would profoundly challenge current societal, political and legal practice on a number of significant levels in general, and demand a significant reworking of notions of citizenship and participation in particular. It is more likely that the radical demands of sustainability will be met in an extensive and ambitious recasting of currently unsustainable modes of action, rather than in desultory tinkering with a system that is comprehensively failing to deliver; ecological thinking has a great deal to offer as one possible approach to engaging with this imperative challenge.

\subsection{Conclusion: Toward a productive synthesis?}

Whilst ecofeminism is an inherently inclusive concept, hugely malleable and multi-faceted, and as such manifesting itself in a myriad of forms, it exhibits 
core characteristics that have a great deal of relevance more generally. In placing a clear emphasis on participation and promoting an active and engaged citizenship, all of which are significant elements in both Code's ecological thinking and broader feminist political activism, ${ }^{125}$ ecofeminism sits well with the dispersed notions of decision-making and responsibility that underpin sustainability. Likewise, the fact that feminist thought in general, and ecofeminism and ecological thinking in particular, posit the necessity of incorporating quotidian or lived experience into politics ${ }^{126}$ also shares core values that sit well with the need and desire to incorporate grassroots elements that are central to sustainability theory and practice. This is particularly the case since so much activity in the realm of sustainability focuses on activities that lie without the usual channels of law and policy development, in what McAfee and Snyder have termed 'the non-governmental places of common problem solving ${ }^{127}$ located in civil society. As Ferguson states:

... just as biological sex does not exhaust the meaning of gender, citizenship does not exhaust the meaning of civic identity. ${ }^{128}$

It is therefore essential that those excluded from predefined commonalities and established channels of influences are positioned, through the empowerment of civil society in its most inclusive form, to attempt to address and contest their exclusion as they see fit and agitate to challenge the status quo. In light of this, there is also much to be said for embracing what Underhill-Sem identifies as the "partnership ethos' ${ }^{129}$ of ecofeminism. ${ }^{130}$ This partnership ethos needs to be more fully exploited in a range of ways encapsulating the partnership between the natural world and humanity, and where humanity is concerned, between professional (scientific, technical, political and administrative) and quotidian knowledge holders.

In the author's opinion, crafting a viable basis for effective interactions between civil society and governmental systems in the broadest sense of the term provides the current locus for discussion and debate of developing the new inclusiveness that must provide the core of any workable and working concept of sustainable governance. A key problem, central to the relevance of ecofeminist and other dominance-challenging perspectives, lies in the fact that, while the moral imperative and possibly even the justice of bringing such excluded views to the table is clear, their viability in actually securing any change in approach and more specifically outcome, is open to serious question. Code addresses this issue by pointing out that, despite their manifest disadvantages, resistance movements have already to some degree managed to exert influence for change in a number of areas, gender among them. ${ }^{131}$ In light of this, advocacy both within and without the system, although as Code rightly points out problematic, has done a great deal to open doors to those formerly excluded from decision-making processes. It is here that law has had the potential to add to developments, though whether 
it has actually delivered much is at this stage highly debatable. However, at the very least, once participation becomes entrenched in soft or hard law, while the influence exerted by formerly excluded groups may not necessarily be proportionate to their social or moral claims, it cannot be so easily disregarded, at least in formal terms. Once procedural entitlements are embraced in law, substantive claims can at least be aired in a highly visible fashion that will, it is to be hoped, make them more difficult to ignore.

Many of the values that this new governance must exhibit can be drawn from broader feminist and ecofeminist theory. These include: an active citizenship founded on participation, with all environment actors promoting participation based on practice rather than simply predicated by status. Shiva persuasively identifies participation as a 'vital human need' ${ }^{132}$ However, it must also be observed that participation, while important in its own right, in order to be meaningful needs to be evaluated in terms of the ability of all participants, not merely to play a part in processes, but also to exert a proportionate influence on the determination of outcomes. ${ }^{133}$

The adoption of inclusiveness in respect of participation in knowledge gathering, policy-making and decision-making, seeks to accommodate the rights of active citizens to meaningfully contribute to addressing and valuing diversity, rather than attempting to impose an artificial uniformity on processes. Such inclusiveness must place commensurate value on the input of all voices to debate and on decision-making based on the cogency of their contribution, broadly interpreted, to the issues in hand.

Inclusiveness seeks to deliver, where possible, a truly consensual (negotiated rather than imposed) approach to knowledge gathering and decision-making processes. While consensual outcomes to such processes may not be possible, as ultimately difficult choices must be made, these will at least be arrived at on the basis of having heard and carefully considered contributions by a whole range of participants. In this respect, inclusiveness offers not so much a cure for, as a necessary counter to the dominance of individualism that characterises much of modern political thought and the laws that it gives rise to.

Furthermore, an inclusive and consensual mode of knowledge gathering and decision-making offers the opportunity to place the shared priorities and collective concerns generated by the demands of sustainability much more prominently within the frame for consideration than is presently the case while, at the same time valuing the contribution of the individual in what Lee terms 'ethical association - an association that sees the need to respect the dignity and agency of each individual', that ultimately enriches democracy. ${ }^{134}$

Finally, in practical terms, it is vital to increase in knowledge gathering and decision-making processes the range and depth of inputs to incorporate not only professional but also quotidian knowledge. This is a prerequisite in order to fashion effective sustainable governance that reflects the complexity of reality and to address the enormous and intertwined social, economic and environmental challenges of progressing the concept of sustainability more 
generally. If human ingenuity is to address the challenges posed by sustainability, we surely cannot afford to be profligate with this resource by discounting huge tracts of knowledge and experience wholesale because it fails to fit the dominant professional knowledge paradigm. To this end it is crucial that we consciously address

the inertia of knowledge practices that stems from their embeddedness in institutional structures. ... ${ }^{135}$

At the same time, our relationship with the environment is also geographically, historically, socially, politically, economically, technologically, culturally and ultimately legally constructed and our approach to progressing sustainability in each of these areas and in the complex interconnections between them is a matter of ever increasing importance. However, over a decade and a half on from Rio, despite developments on paper, the rhetoric of sustainability thus far has made little difference on the ground; environmental degradation continues apace; and despite lip service being paid to participation, in particular though notions such as stakeholding and partnership, the locus of power remains firmly entrenched in the status quo, with the market ultimately at its core. ${ }^{136}$ In this regard the development of policy and law consistently continues to fail to keep pace with human-made impacts on the natural world, a position by its very nature unsustainable and perilous to both biosphere and humanity. The Brundtland Report stated:

National and international law has traditionally lagged behind events. Today, legal regimes are being rapidly outdistanced by the accelerating pace and expanding scale of impacts on the environmental base of development. Human laws must be reformulated to keep human activities in harmony with the unchanging and universal laws of nature. There is an urgent need;

- to recognise and respect the reciprocal rights and responsibilities of individuals and states regarding sustainable development,

- to establish and apply new norms for state and interstate behaviour to achieve sustainable development,

- to strengthen and extend the application of existing laws and international agreements in support of sustainable development, and

- to reinforce existing methods and develop new procedures for avoiding and resolving environmental disputes. ${ }^{137}$

However, little substantive progress has been achieved on any of these fronts and, as yet, despite ever increasing scientific knowledge of the vulnerability of the biosphere to human activity and quotidian experience of the impacts of environmental degradation and resource scarcity across the globe, there is no truly significant political or legal development to shift sustainability beyond mere formalism. 
Perhaps the last word is best left with Code, who observes that:

... theories of knowledge are neither self-contained within philosophy nor isolated from people's lives in the societies where their ideals and standards prevail. ${ }^{138}$

The same is undoubtedly true of laws. Law has the potential to at least facilitate developing the viability of the new inclusiveness in order to begin, albeit tardily, to actualise sustainability by exploiting its potential to mandate broader participation in sustainability praxis. As things stand, and if the established global polis and the law that it generates continue, society will at best lag behind the environmental imperatives and at worst actually retard progress. In light of the pressing ecological problems that we now face, it is about time we harnessed the potential of law, to see it come of age in enabling us to exploit the full breadth of available resources in the attempt to forge not just a better way of living but a sustainable one.

\section{Notes}

1 Shiva, 1993: 160 et seq.

2 WCED, 1987: chapter 2, para. 77.

3 Læssøe, 2007: 233.

4 See, for example, Saarikoski, 2007.

5 See, for example, Princen, 2003.

6 Notable early contributions by individuals include Boulding, 1966, and by groups such as the Club of Rome, in particular in Meadows et al., 1972.

7 Including distinguished work of individuals such as Carson, 1964, and Lovelock, 1982, and the ongoing work of groups such as the IUCN and the IPPC.

8 Another example of the international community's engagement with the need for systemic change is found in ICIDI, 1980 (better known as the Brandt Commission), on which Brundtland also served.

9 Also known as the Brundtland Report, WCED, 1987.

10 The whole thrust of Brundtland, however, remained largely driven by the concept of continued growth powered by increased efficiency and technological optimism, which many would argue fails to grasp the idea that growth is ultimately limited by the earth's carrying capacity.

11 Drawing on the concept first advocated in the IUNC, UNEP and WWF's 1980 World Conservation Strategy.

12 WCED, 1987: 'Chairman's foreword'.

13 WCED, 1987: annexe 2, 'The Commission and its work'.

14 WCED, 1987: chapter 1, para. 43.

15 WCED, 1987: chapter 2, para. 3.

16 WCED, 1987: para. 16.

17 WCED, 1987: para. 81.

18 WCED, 1987: chapter 12, para. 12.4.1.

19 Our Common Future, chapter 12.5, para. 82.

20 See Cullen and Morrow, 2001; Læssøe, 2007: 237.

21 Morrow, 2010b.

22 Runnalls, 2008: 23, 26. 
23 Morrow 2010b.

24 Runnalls, 2008: 22.

25 Læssøe, 2007: 23.3.

26 See Læssøe, 2007, for an illustrative treatment of evolving practice in public participation in domestic law and policy.

27 For a fuller discussion of relevant developments see Morrow, 2006.

28 General Assembly Nineteenth Special Session: Overall Review and Appraisal of the Implementation of Agenda, 21 A/s-19/29, 27 June 1997.

29 www.un.org/womenwatch/osagi/gmsustdevelop.htm.

30 See Morrow, 2006: 45 et seq.

31 See Rocheleau et al., 1996: 3-23.

32 See Rocheleau et al., 1996, re. land reform in Kenya, which, in formalising title, excluded many customary forms of use which had been enjoyed primarily by women.

33 See, for example, OECD (2008): 19.

34 ESCOR Res. 1997/2, 4, UN Doc. E/1997/LO (17 July 1997).

35 Council of Europe, 1998.

36 OECD (2008).

37 OECD (2008), p. 7.

38 See, for example, Benschop and Verloo, 2006.

39 Warren, 1994: 2.

40 Warren, 1994: 2.

41 Warren, 1994: 2.

42 Slicer, 1994: 29 et seq.

43 See, for example, Patel, 1996: 66-71.

44 Notably Merchant: 1981.

45 See, in particular, the Chipko movement and the work of individual activists such as Vandana Shiva.

46 Ferguson, 2007: 30.

47 While it may be more accurate to speak of 'ecofeminisms', for the purposes of this discussion ecofeminism will be taken to encapsulate the broadest possible range of the concept.

48 Basu, 2009: 3.

49 Code, 2006: 7.

50 Ferguson, 2007: 30.

51 Zerilli, 1998.

52 Ferguson, 2007: 35-38.

53 Ferguson, 2007: 40.

54 Sandilands, 1999: xviii.

55 Rocheleau et al., 1996.

56 Underhill-Sem, 2009: 40.

57 Basu, 2009: 8.

58 Notably Code, 1991.

59 Code, 2006.

60 Code, 2006: 5.

61 Code, 2006: passim.

62 Koggel, 2008: 179.

63 Code, 2008: 200.

64 Ockwell and Rydin, 2006.

65 Jasanoff, 1990.

66 Ockwell and Rydin, 2006: 382.

67 Foucault, 1979, 1990. 
68 Ockwell and Rydin, 2006: 381.

69 Hajer, 1995; Hajer and Wagenaar, 2003.

70 Ockwell and Rydin, 2006: 383.

71 Ockwell and Rydin, 2006: 384.

72 Lyotard, 1984.

73 Ockwell and Rydin, 2006: 379.

74 Code, 2006: 4.

75 Code, 2006: 5.

76 Code, 2006: 4.

77 Læssøe, 2007: 233-34; Nelkin, 1975.

78 See, for example, Saarikoski, 2007.

79 Saarikoski, 2007: 488.

80 Fisher, 2003.

81 See, for example, Steele, 2001.

82 Steele, 2001: 437.

83 Beck, 1992.

84 Beck, 1992.

85 Code, 2006: 244.

86 Code, 2006: 244.

87 Saarikoski, 2007: 489; some in the scientific community acknowledge the importance of constructionist approaches: see, for example, Schneider, 2001.

88 Fuchs, 1997.

89 Wynne, 1996; Philippopoulos-Mihalopoulos, 2007, in particular 130-45.

90 Pesendorfer, 2006: 95.

91 Pesendorfer, 2006: 96.

92 Peterson, 2004: 121.

93 Pesendorfer, 2006: 99.

94 Pesendorfer, 2006: 107.

95 Code, 2006: 4-5.

96 Ockwell and Rydin, 2006: 380.

97 Steele, 2001: 437.

98 Irwin, 1995.

99 Code, 2006: 5.

100 Underhill-Sem: 2009, 35-36.

101 Lyotard, 1984.

102 Lyotard, 1984: 19.

103 Philippopoulos-Mihalopoulos, 2007: 142.

104 Lyotard, 1984: 18.

105 Lyotard, 1984: 26.

106 Code, 2006: 280.

107 Code, 2006: 5.

108 Code, 2006: 6.

109 Saarikoski, 2007: 488.

110 Koggel, 2008: 179.

111 Collins and Evans, 2002.

112 Ockwell and Rydin, 2006: 380.

113 Ockwell and Rydin, 2006: 381.

114 This view shares commonalities with Kristin Schrader-Frechette's work on the philosophy of ecological science, in particular Schrader-Frechette, 2002.

115 As per Hunter v Canary Wharf [1997] AC 655.

116 As with environmental claims arising under the route provided by the Human Rights Act 1998, such as Dennis v Ministry of Defence [2003] EWHC 793. 
117 Basu, 2009: 9.

118 Basu, 2009: 10.

119 Dean, 2001.

120 Code, 2006: ix.

121 Code, 2006: 24.

122 Code, 2008: 199.

123 Code, 2008: 200.

124 Code, 2008: 200.

125 Man Ling Lee, 2007.

126 Man Ling Lee, 2007, at p. 165.

127 McAfee and Snyder, 2007.

128 Ferguson, 2007: 40.

129 This is distinct from the narrower concept of partnership as it is understood and practised in the sustainability context discussed above.

130 Underhill-Sem, 2009: 33.

131 Code, 2008: 200.

132 Shiva, 1993: 78.

133 See, for example, Goudie and Kilian, 1996.

134 Man Ling Lee, 2007: 176.

135 Grasswick, 2008: 152.

136 Princen, 2003: passim.

137 WCED, 1987: chapter 12.5, 'Providing the legal means', para. 80.

138 Code, 2006: 4.

\section{Bibliography}

Basu, K. 'What is ecofeminism?' in D. Mitra and K. Basu (eds) Ecofeminism: An Overview Hyderabad: Icfai University Press, 2009.

Beck, U. Risk Society: Towards a New Modernity London: Sage, 1992.

Benschop, Y. and Verloo, M. 'Sisyphus' sisters: can gender mainstreaming escape the genderedness of organizations' 15 Journal of Gender Studies 1 19-33, 2006.

Boulding, K. E. 'The economics of the coming Spaceship Earth' 1966 at http://dieoff. org/page160.htm, accessed 22 May 2009.

Carson, R. Silent Spring London: Readers' Union, 1964.

Code, L. What Can She Know? Feminist Theory and the Construction of Knowledge Ithaca NY: Cornell University Press, 1991.

Code, L. Ecological Thinking: The Politics of Epistemic Location Oxford: Oxford University Press, 2006.

Code, L. 'Thinking about ecological thinking' 23 Hypatia 1 187-203, 2008.

Collins, H. and Evans, R. 'The third wave of science studies: studies of expertise and experience' 32 Social Studies of Science 235-96, 2002.

Cooke, B. and Kothari, U. (eds) Participation: the New Tyranny? London: Zed Books, 2001.

Council of Europe, Gender Mainstreaming: Conceptual Framework, Methodology and Presentation of Good Practices Strasbourg: Council of Europe, 1998.

Cullen, H. and Morrow, K. 'International civil society in international law: the growth of NGO participation' 1 Non-state Actors and International Law 7-39, 2001.

Dean, H. 'Green citizenship' 35 Social Policy and Administration 5 490-505, 2001.

Ferguson, M. L. 'Sharing without knowing: collective identity in feminist and democratic theory' 22 Hypatia 4 30-45, 2007. 
Fisher, F. Reframing Public Policy: Discursive Politics and Deliberative Practices Oxford: Oxford University Press, 2003.

Foucault, M. Discipline and Punish: the Birth of the Prison New York: Vintage, 1979.

Foucault, M. The History of Sexuality, Vol. 1, An Introduction London: Penguin, 1990.

Fuchs, S. 'A sociological theory of objectivity' 11 Science Studies 1 4-26, 1997.

Grasswick H. E. 'From feminist thinking to ecological thinking: determining the bounds of community' 23 Hypatia 1 150-60, 2008.

Goudie, S. and Kilian, D. 'Gender and environmental impact assessment' 29 Agenda: Women and the Environment 43-54, 1996.

Hajer, M. A. The Politics of Environmental Discourse: Ecological Modernisation and the Policy Process Oxford: Oxford University Press, 1995.

Hajer, M. A. and Wagenaar, H. Deliberative Policy Analysis: Understanding Governance in the Network Society Cambridge: Cambridge University Press, 2003.

Independent Commission on International Development Issues (ICIDI) North-South: a Programme for Survival: Report of the Independent Commission on International Development Issues London: Pan Books, 1980.

Irwin, A. Citizen Science: a Study of People, Expertise and Sustainable Development London: Routledge, 1995.

IUNC, UNEP and WWF World Conservation Strategy Nairobi: UN Environment Programme, 1980.

Jasanoff, S. The Fifth Branch: Science Advisors as Policy Makers Cambridge MA: Harvard University Press, 1990.

Koggel, C. M. 'Ecological thinking and epistemic location: the local and the global' 23 Hypatia 1 177-86, 2008.

Læssøe, J. 'Participation and sustainable development: the post-ecologist transformation of citizen involvement in Denmark' 16 Environmental Politics 2 231-50, 2007.

Lovelock, J. Gaia: A New Look at Life on Earth Oxford: Oxford University Press, 1982.

Lyotard, J. F. The Postmodern Condition: a Report on Knowledge Manchester: Manchester University Press, 1984.

McAfee, N. and Snyder, R. C. 'Feminist engagements in democratic theory' 22 Hypatia 4 vii-x, 2007.

Man Ling Lee, T. 'Rethinking the personal and the political: feminist activism and civic engagement' 22 Hypatia 4 163-79, 2007.

Meadows, D. H. et al., The Limits to Growth: a Report for the Club of Rome Project on the Predicament of Mankind London: Earth Island, 1972.

Merchant, C. The Death of Nature: Women, Ecology and the Scientific Revolution London: Wildwood House, 1981.

Mitra, D. and Basu, K. (eds) Ecofeminism: An Overview Hyderabad: Icfai University Press, 2009.

Morrow. K. 'Gender, law and environmental citizenship' in S. Buckingham and G. Lievesley (eds) In the Hands of Women: Paradigms of Citizenship Manchester: Manchester University Press, 2006.

Morrow, K. 'Sustainable development, major groups and stakeholder dialogue: lessons from the UN' in D. French (ed.) Global Justice and Sustainable Development Leiden: Nijhoff, 2010b.

Morrow, K. 'Worth the paper they are written on? Human rights and the environment in the law of England and Wales', 1 Journal of Human Rights and the Environment 1 66-88, 2010a. 
Nelkin, D. 'The political impact of technical expertise' 5 Social Studies of Science 2 35-54, 1975.

Ockwell, D. and Rydin, Y. 'Conflicting discourses of knowledge: understanding the policy adoption of pro-burning knowledge claims in Cape York peninsula, Australia' 15 Environmental Politics 3 379-98, 2006.

OECD Gender and Sustainable Development: Maximising the Economic, Social and Environmental Role of Women (2008) at http://www.oecd.org/dataoecd/58/1/40881538.pdf.

Patel, Z. 'Women and environmental management' 29 Agenda: Women and the Environment 66-67, 1996.

Pesendorfer, D. 'EU environmental policy under pressure: chemicals policy change between antagonistic goals?' 15 Environmental Politics 1 95-114, 2006.

Peterson, J. 'Policy networks' in A. Wiener and T. Diez (eds) European Integration Theory Oxford: Oxford University Press, 2004.

Philippopoulos-Mihalopoulos, A. Absent Environments: Theorising Environmental Law and the City, London: Routledge, 2007.

Princen, T. 'Principles for sustainability: from cooperation and efficiency to sufficiency' 3 Global Environmental Politics 1 33-50, 2003.

Rocheleau, D., Thomas-Slayter, B., and Wangari, E. 'Gender and environment: a feminist political ecology perspective' in D. Rocheleau, B. Thomas-Slayter and E. Wangari (eds) Feminist Political Ecology: Global Issues and Local Experiences London: Routledge, 1996.

Runnalls, D. 'Our common inaction: meeting the call for institutional change' 50 Environment 6 19-28, 2008, at www.environmentmagazine.org.

Saarikoski, H. 'Objectivity and the environment: epistemic value of biases' 16 Environmental Politics 3 488-98, 2007.

Sandilands, C. The Good-natured Feminist: Ecofeminism and the Quest for Democracy Minneapolis MN: University of Minnesota Press, 1999.

Schneider, S. 'A constructive deconstruction of deconstructionists: a response to Demeritt' 91 Annals of the Association of American Geographers 338-44, 2001.

Shiva, V. 'Women's indigenous knowledge and the Biodiversity Convention' in M. Mies and V. Shiva (eds) Ecofeminism London: Zed Books, 1993.

Shrader-Frechette, K. Environmental Justice: Creating Equity, Reclaiming Democracy (Environmental Ethics and Science Policy) USA: Oxford University Press, 2002.

Slicer, D. 'Wrongs of passage: three challenges to the maturing of ecofeminism' in K. J. Warren (ed.) Ecological Feminism London: Routledge, 1994.

Steele, J. 'Participation and deliberation in environmental law: exploring a problemsolving approach' 21 Oxford Journal of Legal Studies 3 415-42, 2001.

Underhill-Sem, Y. 'Why a feminist perspective is urgently needed in ecological issues and related social struggles of the time' in D. Mitra and K. Basu (eds) Ecofeminism: An Overview Hyderabad: Icfai University Press, 2009.

Warren, K. J. 'Introduction' in K. J. Warren (ed.) Ecological Feminism London: Routledge, 1994.

World Commission on Environment and Development (WCED) Our Common Future Oxford: Oxford University Press, 1987.

Wynne, B. (1996) 'May the sheep safely graze? A reflexive view of the expert-lay knowledge divide', in S. Lash, B. Szerszynski and B. Wynne (eds) Risk, Environment and Modernity: Towards a New Ecology London: Sage, 1996.

Zerilli, L. 'Doing without knowing' 26 (4) Political Theory 435-58, 1998. 


\title{
Animals and the future salvation of the world
}

\author{
Piyel Haldar
}

Without the ... hope of the last judgement, the Western legal tradition could not have come into being. ${ }^{1}$

\section{I Introduction}

The term 'environmental law' suggests two possible sources of sovereignty. On the one hand, and somewhat obviously, 'law' refers us to the full constitution of protocols, decision making procedures and statutes determined in the name of national sovereignty, as well as to the more general principle of jurisdiction under which all decision making and norms are proscribed by legal sovereignty. On the other hand, 'environmental law' draws from broader non-legal and non-state principles (scientific, philosophical, cultural) relating to the care, remediation and management of the biophysical sphere. It simultaneously alerts us to the possibility that the environment itself might be regarded as sovereign; that it is the environment itself, its fate and its future in the face of human-made catastrophe, that ought to determine the decision making process, the terms of agreements and indeed the very structure of social life and culture. A sort of green sovereign emerges from the earth itself. Characterised as mother, cosmic force, gaia, the future, or any number of other avatars, such sovereignty calibrates the efficacy and merit of the law only in its own best interests.

And yet, from the perspective of modern legality, there is no real competition between these two sovereign principles. To decide environmental issues within the legal arena already acknowledges that the status of the environment falls below the requisite standards expected of sovereignty. The clear triumph of law over the environment indicates, and indeed, rests upon a hierarchical distance between 'man' and what he inhabits. Equally, what allows for the superiority of 'man' over the natural environment has to do with the sovereignty of law itself. In order to chart the emergence of law's role in what Giorgio Agamben calls the anthropological machine - the discursive and material apparatuses that maintain the distinction between humanity and animality - what has to be understood is how law, just like 
post-pagan and post-axial religions, overturns a state of affairs in which man was subject to the sovereignty of the environment. ${ }^{2}$ Law, in other words, reverses a once-held state of affairs in which nature once determined the law.

By focusing on a range of Christian didactic literature dealing with animals, this chapter ${ }^{3}$ charts the process from which the environment is seen as sovereign to the excision of nature in the role of world formation; a process that might be described as moving from the verdant to the desiccated. Moving from an understanding of standards of normativity that are measured by and inhere within the natural environment, such literature culminates in what might be termed the modern juridico-anthropological machinery that separates man from the very environment he inhabits. What will be argued is that the primacy of law over nature is rooted in a particular mode of Christian hermeneutic that posits an exterior law that establishes the natural scheme of things and cultivates man accordingly. Nature becomes a mere cipher for divinity and for a law. It hides the ultimate source of life and provides clues as to the character of a universal law. Nature as a mystical set of clues or ciphers thus engenders and cultivates in Christian subjectivity a process of decoding. The environment we inhabit is to be read as a text subsisting outside the self; it has to be cracked and deciphered only through the internalised process of human reasoning. The various chronicles that present the hermeneutic imagining of the natural environment simultaneously present us with an understanding of Law's process of becoming other: the making possible and regulation of social relations within culture operates only through the imaginary order of nature.

In charting the role played by Christian didactic, what will be argued further is that this historical process leading to the legal excising of nature and animality does not completely disavow a certain characteristic of sovereignty associated with the natural world. This characteristic might be defined in relation to a notion of a coming salvation. What will become clear is that the animals that form the subject matter of the literature under investigation in this chapter take a certain pride of place not simply because they betray Divine mystery but because they usher and indicate a specifically Christian idea of a future salvation. Animals, being God made yet separated from the Adamic heredity of man, existed without original sin. They alone retained a purity denied to post-lapsarian humanity and were given what Ernst Kantorowicz terms a 'halo of perpetuity'. ${ }^{4}$ Thus, Kantorowicz notes, the biblical homily of the little donkey who carries Christ into Jerusalem on Palm Sunday perfectly illustrates the relationship between animals and the economy of salvation. The donkey is at once physical flesh and can thus be returned by Christ to his original owner once he has carried out his function of transport. But the sinless donkey is also sempiternal, messianic and 'haloed'. It is the immortal quality of the animal messianum that stays with Christ in the Holy City which is itself an allegory of eternity. ${ }^{5}$ Because pure, these animals were best suited to the purpose of describing to Christian 
man all that he needed to be saved: 'But ask the animals and they will teach you.' 6

It is this Christian notion of a future and eternal salvation that makes animal didactic literature so relevant and characterises modern law's relationship to sovereignty. It is a feature associated with the idea of nature's proximity to sovereignty that is retained by Western legal systems. There are a number of ways in which this observation about the normative dimension of fabulous animals impacts on the specific understanding of law. The idea of salvation is clearly incorporated into understandings of political sovereignty. Any declaration of a state of exception, which for Carl Schmitt determines the nature of sovereign, for example, is a rhetorical moment that is accompanied by the dubious statement that 'eventually all will be all right' or 'the end justifies the means'. Consequently, all other present priorities are suspended, deemed non-urgent, until some future resolution has been achieved; until the global economy has been put in order, until we are once again unified in the name of capitalism, until the enemy has been defeated, until the terror has subsided. The exception is always that which lives in the shadow of an imagined future. The Christian literature on animals presents Western legal thought with the idea that the future provides a single voice that speaks pro nobis. Law, in other words, is not simply coordinated by the past, by the wisdom of elders, or by tradition. It refers equally to, and is defined equally by, the future, by hope and by the concept of salvation.

More specifically, however, and to the extent that it incorporates at least something of current environmental concerns, environmental law perfectly reflects this key logic of modern Western legal systems. That is to say, in attempting to initiate the sovereignty of the environment, it too looks toward some significant future point in which salvation might be reached. Environmental action groups might well take a stance that is seemingly and vehemently anti-legal and anti-state. To be sure, there is a great deal to be said about claims that our faith in law has disintegrated, that political language can only inadequately express planetary disaster and that the covenant of things is broken. But the call to 'save the planet' is simply a provocation of the most conservative and conserving of sovereign principles that determine the law by turning to the language of the future as something absolute that hold things together. It becomes one call among many that attempts to steer the trajectory of political and legal discourse towards an anticipated horizon. The environment and the non-human animal that inhabits it do not only remind man of an uncivilised or anarchic past but cipher an idea of the future to be harnessed as a regulatory principle.

The features of Christian literature that establish both the juridicoanthropological machinery and the soteriological discourse in the heart of the present chapter might be preliminarily highlighted. First, animals depicted in the early Christian, or physiologus bestiaries symbolised the mystery of creation, the divine provenance of all things and the attributes of that 
divinity. In so doing, a specific hermeneutics developed in order to reveal through the animal kingdom a logos which was higher than anything that might be said to reside in nature. Second, a later medieval development in the literature used the same animals in order to allegorise a normative code for the behaviour of man in preparation for his salvation. Here the bestiary emblematised man rather than god; the animal, as it were, penetrated man. This process will be examined by tracing the development of animal symbology across three broad categories of relevant literature that constitute the medieval obsession with animals. These are natural histories, mystical zoography (or the physiologus bestiaries) and later medieval bestiaries. Each will be examined in turn, paying attention to the development of a semiotic system that carefully arranges the place of man within his environment, in relation to Divinity and finally in relation to notions of redemption.

\subsection{Pagan mythology and Aristotelian zoology}

While not directly or obviously Christian in their moralising content, it is important briefly to note two substantial categories of literature that occupy a relationship to, and influence, the later Christian bestiaries. First are the collections of mythologies, such as those of Aesop and Ovid. ${ }^{7}$ In their explicit and implicit worshipping of nature, pagan mythology quite obviously stood in direct contrast to Christianity. Animals, here, did not symbolise a divine entity separated from the environment; they did not instruct by virtue of divine provenance. Nevertheless, individual characters and narratives from this sub-genre of literature were incorporated and transformed into the bestiary tradition. It is through the transformation from paganism to Christianity that a new hermeneutic structure is developed that, as will be shown, radically transforms man's relationship to the animal kingdom.

The second category of pre-Christian animal literature might loosely be termed Aristotelian and incorporates a broad range of natural histories (such as Pliny's Natural History) ${ }^{8}$ and encyclopaedias (such as Isidore of Seville's Etymologiae). ${ }^{9}$ Descriptive and anecdotal, these were largely clear of any sort of explicit moralising. They were, quite obviously, as the term 'natural history' suggests, inquiries into the infinite variety of nature. Meticulous surveys are provided of known geography, ethnography, anthropology, physiology, botany, agriculture, horticulture, metallurgy and mineralogy. Each natural history would therefore devote a significant volume to a zoological survey of the world. Predominantly influenced by Aristotle's History of Animals, ${ }^{10}$ classical zoology was concerned with tabulating the ontological place of animals within the natural universe. Members of the living kingdom were placed into chapters depending on their genus and differences. While these classical accounts might include oddities and improbabilities, the authors cling to firm facts (albeit facts that were often transmitted anecdotally). As with the mythological, or Aesopian, tradition, Aristotelian histories held no clue as to 
any divine providence that may or may not subsist within nature. The environment, a set of self-sovereign facts, simply existed. The environment held no moral value and provided no hidden narrative lesson about man's place on Earth. As a result of this lack of moralising, later theologians would accuse the classical authors of these merely technical histories of having falsified the world soul, voiding nature of any symbolic and divine ordinance. Nevertheless, such logical classification, which culminated in being expressed according to the epistemological model of the Porphyrian tree, is not totally removed from the realms of the more fabled and fabulous bestiaries. ${ }^{11}$ It ought to be remembered that in Book VIII of his Natural History Pliny records his belief in the existence of werewolves as well as 'the amphisbaena, the basilisk, the catablepa, the crocoti, the corocoti, the leukocroti, the leontophont and the maticore, all destined to go on to crowd the bestiaries of the Middle Ages'. ${ }^{12}$ There is more to the influence of the Aristotelian natural histories since, as shall be argued, the natural history of animals lays a descriptive field on which the symbolic animal, in the most didactic examples of Christian animal literature, is allowed to graze!

\subsection{The post-pagan bestiarum vocabulum}

The normative turn in distancing the sphere of humanity from its environment begins with the incorporation of pagan mythology and Aristotelian histories into more symbolically charged Christian didactic. This Christian tradition of animal literature consists of the curious mystical compendia derived largely from the Physiologus (the title is seldom translated but, when it is, it is usually as 'Naturalist') as well as the various Patristic Hexahemera (accounts of the six days of Creation). ${ }^{13}$ Dating from the second century AD, the Physiologus in particular (correctly or incorrectly attributed to a 'Theobaldus' who lived, if he did live, in Alexandria) collected from the pre-literate tradition of Mediterranean folklore a number of these animal tales and herded them towards Christian homily. The text is organised into forty-nine chapters each of which is devoted to the characteristics of an actual or fabulous animal; each animal is illustrative of some aspect of Christian doctrine. The Physiologus stands as a particular and significant example of the Christianisation of pagan deities. Christ the 'aethereal bee' buzzes around, as it were, pollinating a once pagan life with his own Divinity. The eagle as an emblem of Jupiter, for example, metamorphosed into an emblem of John the Baptist. ${ }^{14}$ The Physiologus and various later translatio (there are innumerable examples of post-Theobaldus Physiologus bestiaries), were regarded as much more than a 'system of mystical zoology'; they were more a species of Christian didactic.

Appointed by monasteries and illuminated by monks, the Physiologus bestiaries form a tradition of Christian literature in which animals were only ever allegorical. Such texts were symbolic rather than natural; Augustinian 
rather than Aristotelian. Just as they attempted to take over pagan thought, they also rejected the scientific studies of Aristotle and pretensions of both Pliny and Aelian. ${ }^{15}$ As a consequence, the taxonomy of animals was not constrained by any sense of actuality but by (collective) imagination. No distinction was made, nor should be made, between the credible and the incredible; the fabulous was permitted to mix quite freely with the actual. With no apparent theoretical difficulty, unicorns, onocentaurs, jacalus, ichneumons, ieucrots, alerions and amphisbaena coexisted with blackbirds, camels, giraffes, oxen, asps or dogs. Whatever the animal, they became perceptual figures of that other scene or primary Cause. The clear purpose to the Physiologus bestiaries was not the impersonal or meticulous observation of nature. Nature was but the conduit, or cipher, pointing to God. Consequently, the acts or habits for which the animals of these bestiaries were renowned were similarly allegorical. Thus the fable of the lion who never closes his eyes (et quotiens dormit, sua nunquam lumina claudit) ${ }^{16}$ was to be read as Christ's eternal watchfulness over the souls of men. Salamanders who could not be consumed by fire referred to the righteousness of Christ. Hydra (enhydro), who ate the intestines of a crocodile from the inside, represented Christ saving souls from the depths of hell. Unicorns who could be tamed only by a young virgin were allegorical of Divine purity. Barnacle geese that grew on trees, or ant-lions that were the offspring of both lion and ant were all examples of hidden and mystical providence and therefore True. ${ }^{17}$ The adoption of the Physiologus by early Patristic teaching was grounded in the capability of animal allegories in making known the mysteries of Christ or the Divine creation and, consequently, came to be appropriated as a key medium in broadcasting the 'lessons' of the New Testament. By the later Middle Ages the animals of the Physiologus decorated chancels and chapels, were embroidered on sacerdotal vestments and wrought upon ecclesiastical furniture, vessels and reliquaries. What mattered about this esoteric text was emphatically not the empirical observation of the Aristotelian natural histories but rather the element of 'make-believe' or faith. The discourse on the becoming of nature (physiologia) is here inextricably linked to the discourse on the genealogy of the Gods (theologia). ${ }^{18}$

In different terms, linking physiology to theology presents the structure of the world as an ordained and unified whole. Nature, tabulated by the Aristotelians as manifold, is defined within the bestiary tradition as disclosing only one true providential nature. Nature ceases to exist as a factual selfsovereign existence. This is why the difference between actual and imaginary creatures cannot be maintained. The environment is simply a cipher, a tool, symbolic fodder to feed the Christian appetite for God. The assimilation of paganism, however, was not a straightforward act of putting ancient animal figures to Christian use. Under Christianity, a new theory of signs had to be developed according to which the physicality or imaginary qualities of the natural environment referred not to itself but to an abstract idea. That such 
reference could be made known only through symbol or allegory was fully concordant with the semiotic formula of Origen and Augustine by which created objects in nature were suffused with both literal and symbolic meaning. The word 'lion' referred to an object lion that in turn referred to yet another object (the divine). The allegorical path opened up in order to reveal what, without this semiotic formula, would remain hidden. The Heraclitean fragment 'nature loves to hide' (phusis kruptesthai philei) was given a particular spin. What nature hid was an external divinity and its revelation could be made only through semiotic exercise or, in other words, through man's reason. ${ }^{19}$ Cassian in the fifth century clearly distinguished allegorical from historical knowledge for precisely these reasons. Allegorical knowledge (along with tropological, and anagogic knowledge) was spiritual knowledge. ${ }^{20}$ The Physiologus was thus hermeneutic in design and to be described as claves scripturae sacrae (key to the holy scriptures).

Moreover, the deciphering of animal symbols and allegory is to be considered crucial to the constitution of Christian subjectivity, for only man can decipher, since his alone is the province of reason. This is what allows him to impose his sovereignty over the natural environment and distinguishes him from both animals and pagans. That is to say, the manner in which man emerges triumphant over beasts in the didactic tradition of animal literature is based not so much on the attribution of logos as on the ability of man alone to determine and thereby possess meaning in the world. The determination of animal symbology is given its most coherent systematisation as a result of Christian semiology. Indeed, the normative function of animal symbology was never as strong as during the long process of Christianising the West. Under paganism, the (symbolic) function of animals was a celebration of nature as the Goddess natura. Nature was in and of itself both a matter of ontology and of destiny. On the part of ontology, man cohabited with nature; his being was only ever being-with nature. On the part of destiny, the word 'symbolic' would be a misnomer, for the animal did not refer to natura but was natura. It is Christianity that introduces the symbolic schema by putting into effect the radical revolution in religious thinking inaugurated by the great thinkers of the Axial Age and famously analysed by Karl Jaspers. ${ }^{21}$ Christianity opposed the social bond existing between man and nature. Indeed, while borrowing from pagan animal lore, Christian literature of this kind completely opposes pagan zoolatry and places instead a vertical bond between man-below and God-above. Christianity thus transforms our relationship to the world by eradicating this sense of being-with animals and splitting the here below from the divine other. ${ }^{22}$ Under Christianity, animals took on symbolic valency by pointing to, or becoming, 'ciphers' of an exteriority that transcended nature. ${ }^{23}$

The Christian semiotic formula alerts us to a further significant development in the shift away from paganism. It has to be stressed that the distinction between the fabulous and the actual is unimportant to the medieval 
reception of these texts. The modern distinction between imagination and perception cannot be applied to this species of literature whose purpose is far from scientific. The material constitution of animal bodies are only symptoms of an ancient intelligible life force, an a priori soul that exists before nature. ${ }^{24}$ Nature is but a secondary symptom that along with imaginary beasts points to a hidden logos that knows no distinction between form and myth. In this sense, Christianised fables are also denunciatory of pagan worship of the Goddess naturalphysis who ruled over men's souls. There could be nothing more unnatural to Christianity than the worship of nature; nothing more given to the darkness of the soul than the zoolatrous worship of a cat, pig or bull. Under Christianity, nature simply stands in as messenger for that absolute idea, that absolute reference, that hidden $\log o s$, etc. The position is maximised by St Paul: 'God is clearly seen by the mind's understanding of created things. ${ }^{25}$ The natural world was to be treated only as a vivid scripture, a 'living manuscript', that codified and revealed all the qualities of the Christian Divinity and the tremendous mystery of His creation: 'This whole visible world is a book written by the finger of God. ${ }^{26}$ In this sense, nature took its place alongside the Bible and the inner soul in the provision of divine exemplars. That the logos hid in nature forced everything that resides in the world to be subject to a Christian meaning. Allegory established law over nature. It fixed the stars in position. And, once a law is admitted as sovereign, the whole empyrean extent of the animal kingdom knew its place. Aristotelian natural histories, according to medieval theologians, had failed to establish a world soul precisely because they failed to recognise this law.

It is according to this semiotic scheme that Christianity instituted a revolution in the relationship between man and animal and in the very status of what it meant/means to be in the world. In rejecting the pagan worship of animals in favour of a higher law, Christianity turns man against nature. Under paganism any aggression towards nature, however necessary such as hunting, had to be compensated. A balance had to be restored through the protocols of ritual sacrifice. ${ }^{27}$ Nature, in other words, was to be received only under conditions of profound ontological humility. Under Christianity, on the other hand, natural life surrenders to a higher logos. Rather than received, nature is to be consumed and its meaning controlled. In the theological terms set out by Karl Jaspers, nature (whether the natural world, or our natural biological selves) becomes a 'cipher', something other than its appearance. Christian allegory killed the animal spirit of life in order to make it speak of this exterior and supernatural otherness. The Christian subject consented to nothing other than a logos completely separated from the here-below. The description Marcel Gauchet gives to Christianity as 'the religion that brings about the exit from religion' must be understood not simply in terms of the syncretic unification of disparate religious beliefs. ${ }^{28}$ Rather, the revolution in religious thinking is one that brought about the primacy of law over nature. Animals were no longer worshipped, the 
environment no longer needed to be appeased through pagan rituals. Nevertheless, the natural environment provide a hermeneutic key that indicated the sovereignty of the logos.

\subsection{Later bestiaries}

However, the business of deciphering animals alone does not grant man his triumph over nature and account needs to be taken of a further shift brought about in the late medieval literature. This further shift emerges out of a third category of animal literature popularised onwards from the twelfth century. This category might be characterised broadly as a synthesis of the previous two. These later medieval bestiaries combine the descriptive flavour of the natural histories/sciences with the mysterious signification of the Physiologus. The natural and visible world, in other words, functioned in much the same way as other symbolic images and alerted medieval man to the Christian scheme of things and the Divine plan. However, keener stress was placed on the scientific descriptions of the Aristotelian tradition. They adopt their own didactic structure commonly by proceeding from 'observed' details of particular animals to anecdotes and fables that, like those of the Physiologus, are constructed as allegories. Thus, for example, the idea that 'towards man the nature of the Lion is kind, so that they cannot become angry unless attacked' refers to the ideal qualities of noble personality by highlighting the supposed qualities of actual lions. ${ }^{29}$

The significance of this category of texts, and what properly distinguishes them from other categories of animal literature, is that what is being allegorised is not always, or solely, the hidden qualities of the Christian logos. The allegorical function of the late medieval bestiary is no longer simply to transmit the divine cause and provenance of life, nor is it simply to make manifest the biblical qualities of Christ. Rather, animals become symbolic of Christian values and the ideal qualities of man. The hidden logos that inheres in nature determines and instructs behaviour and social relations. The natural environment comes to be treated as a source for the instruction of man in all manner of social and cultural activities. This development seems to have been neglected by literary scholars of this genre. The 'love bestiary' of Richard de Fournival, for example, is famously formatted as a troubadour disquisition on amatory practices. $^{30}$ Its primary allegorical referent is the male lover, his fortunes and his melancholy. The lover is represented in turn as a unicorn kneeling before a virgin, a cockerel crowing for his love, a braying ass, a dying swan and, finally with triumphal misogyny, a dog returning to his own vomit.

Bestiaries such as Fournival's, guide a course of action and steer man towards proper conduct. The emphasis crucially moves from faith to living. Two sources might be said to influence this shift. The first is the influence of the following biblical aphorism: 'But ask the animals and they will 
teach you. ${ }^{31}$ In bestiaries less bent on romantic pursuits, animals reprove and instruct on all manner of human behaviour. They warn, for example, of the dangers that lie in wait for man along the heaven-bound path; hence the dragon, represented in the Aberdeen bestiary, which lies in wait and traps the unwary elephant. The second source is an increasing reliance on Aristotle's natural history, according to which the human-like features of animals are instructive. Edward Topsell's History of Four-footed Beasts (1607), for example, invokes Aristotelian natural history in order to provide a neat lesson against murder and tyranny: 'Were this not a good persuasion against murder, to see all beasts so to maintain their natures, that they kill not their own kind? ... And what King is not invited to clemency, and dehorted from tyranny, seeing the King of Bees hath a sting, but never useth the same?'32 In his entry for the bull, Topsell cites the proverb 'He may bear a bull that hath born a calf.' Or the corruption of youth increases with age. The epimythia is summarised in the following anecdote: 'Quartilla was a woman of most vile reputation for uncleanness because she said when she was little she lay with little ones like her self, and when she grew bigger, she applyed her self to the pleasure of elder men, growing in filthness as she had increased in years. ${ }^{33}$

The natural world invariably described as a sacred manuscript now became the province of imitation. Following Andreas PhilippopoulosMihalopoulos's etymological breakdown of the term, a proper 'ecology', or logic of the oikos, emerges that connects ecology to iconology (the logic of the icon) as the figurative focus of contemplation and imitation. ${ }^{34}$ In the words of Alan of Lille, 'Every creature of this earth/is as if a picture or a book./It is a mirror of ourselves. ${ }^{35}$ Thus, while man replaced God as the symbolic referent, the hermeneutic exercise that characterised the early Physiologus bestiaries remained intact. Here, nature was to provide a sacred key to the norm of human conduct. According to Thomas de Cobham, 'the whole world is full of diverse creatures, like a manuscript full of different letters and sentences in which we can read whatever we ought to imitate or flee from' ${ }^{36}$ This hermeneutic act of deciphering fully conformed to the cultural shift of the twelfth-century renaissance towards man-centred thought.

These later bestiaries are no less esoteric than those of the Physiologus bestiaries; for the proscribed norm not only has to be imitated but also to be incorporated within the subjective self. In more precise terms, nature was the incarnation of quality, the imago virtutis. Through the contemplation of the bestiary, man constructed within his soul the arca sapientiae, the dwelling place for divine wisdom. As Peter Goodrich notes of emblems more generally (and of Alciato's in particular), the exemplars and their norms 'are not simply prosaic statements of miniscule and technical rules. They attach to life, they go within. ... they institute life, they pass on the habitus of the human. ${ }^{37}$ The path to wisdom, the construction of the arca sapientiae, did not arise out of simple contemplation. It was a matter of hermeneutic and 
rational decoding and as such was reflected in a more complicated semiotic schema than that which arose from that other, albeit similar, genre of Christian literature dealing with virtue and vice, and with the psychomachia (the fight for 'mansoul') of the Christian subject. ${ }^{38}$ The passionate life energy of animals did not lend themselves obviously to the schematised personification of virtue and vice; the range of moral qualities illustrated by bestiaries were broader and the stark division between them did not apply. Individual animals, by dint of natural and fantastic history, were given qualities more flexible than the seven virtues and were capable of a wider spread of vices. Animal passions were not simply malignant (or simply benevolent) but rather through action symbolised the complex elemental intensity of human action. These bestiaries found greater flexibility in recording different, more nuanced, states of being in the human soul while at the same time allowed for a meditation upon the meaning of 'passion' as a specific Christian mode of perfection. They laid out for inspection the more extensive emotional grammar of man (a brief scan of the literature would reveal the following and more: frugality, pluckishness, prevision, malice, lust, ill temper, uncouthness, industry, pertinacity, sportiveness, cowardice, lumpishness, submission, deceit, longevity, chastity, verbosity, and so on). It was through the symbolic animal that man could take himself apart in order to reflect on his ideal constitution, his potential for completeness or his departure from the divine plan.

In semiotic terms, such literature might also be distinguished from other genres of Christian didactic in so far as they relied on shifting signifiers. Without any loss to the overall coherence or economy of an individual piece of work, animals were capable of springing about from referent to referent. Often a single animal would be riddled with qualities of virtue and vice; a single animal might serve the church or might be a stooge of His Satanic Majesty. Hence the partridge signals characteristics as varied as fidelity, the devil, unjust wealth and false parenthood. Or a lion was both ferocious and compassionate. Predictably enough, Alciato emblematised the bull as being straightforward, a strong and valiant warrior. But, for him, the bull also demonstrated restraint, since it was (and may still be) known for keeping away from pregnant females. The lesson according to Alciato, is that 'we ought to suffer much, and keep our hands away from things forbidden'. ${ }^{39}$

All the fundamentals of ethical man were to be found among animals. The imaginary order of the natural world provided a model for imitation that helped establish the social (non-natural) order of the Christian world. What is, of course, paradoxical is that these animal qualities, which in an ideal state represented moral and Christian perfection, would also enable man to designate himself as cultivated, civilised and non-animal. In order to distinguish himself from the bestial order, man mirrored those virtues of animality that better represented perfection and salvation. As Nietzsche observes of man, 'he envied the wildest, most courageous animals and robbed all their virtues; only thus did he become man'. ${ }^{40}$ 


\subsection{Salvation}

In spite of the disavowal of the pagan notion of primacy of the natural world, animals nevertheless retained a proximity to a certain sovereignty. Animals occupied two temporal points in the trajectory of man's development. They were placed at the forbidden and pagan point of departure; they marked the point from which man distanced himself. At the same time, and more important, they indicated man's destiny, an end point of perfection and salvation. Animals provided an orthopaedic model of behaviour but they did so in order to indicate the day of judgement and the possibility of redemption as the organising principle of terrestrial life. Clues to the life hereafter in other words, were held locked in the imaginary order of the natural environment. The point is emphasised by a number of key animals in the bestiary, most commonly the phoenix. Lactantius's Carmen de Ave Phoenice (Song of the Bird Phoenix) written in the fourth century, became immensely popular from the eleventh century onwards, making its way into later versions of the Physiologus. ${ }^{41}$ It is given central emphasis in the Anglo-Saxon Codex Exoniensis (the Exeter Book):

\section{O happy bird that knows}

No bond of love! Death is thy only love,

Thy one delight is death! Thou longst for death, That thou may'st be new born. Thou art thyself, Yet not the same, thyself yet not thyself, Attaining life eterne through fecund death. ${ }^{42}$

The legend came to signify more than the singular event of Christ's resurrection. It is man's longing that is turned towards death/eternal life signifying the potential for all mankind to rise from the ashes, purified and ready to enter paradise. This turn toward the possibility of salvation and redemption also informed a slightly different pedagogic function of fabulous beasts both in literature and ecclesiastic architecture. Such beasts, while directed towards man, were reified as portents rather than as ideal qualities. For, as Topsell puts it, 'beasts both of natural and extraordinary shapes [show] to prophets, the ruin or uprising of beastly states and kingdomes'. ${ }^{43}$ These were the beasts of the Revelations of St John the Divine heralding the ultimate destination and end of time. But such beasts were also to be found in the Liber Monstrorum de Diversis Generibus (The Book of Monsters of Various Kinds) and the Epistola Alexandri ad Aristotelem (Letters from Alexander to Aristotle), both of which located these beasts in the filth and excess of the geographical East. ${ }^{44}$ Examples include the dentestyrannus (or tyrant's tooth), giant bats, the eternal beast, etc. Whether biblical or epistolary, these fantasmatic beasts indicate and warn of God's plan. ${ }^{45}$ As Edward Evans notes, the great atonement is to be signalled by 'the disappearance of all antipathies between savage 
beasts and their natural prey ... ${ }^{46}$ The lion will lie down with the lamb. Eden will return.

In other words, both in terms of heralding the Judgement to come, and in heading a moral march towards salvation, what is emphasised is the profound ephemerality of 'man's' life itself. The natural environment, omni-temporal, God-made and prophetic reminds the Christian subject that the regulated social order is lacking and temporary. Cultural life remains but a wisp compared with the more divinely proximate creatures of the non-cultural environment. Indeed, this life-itself of man is conceived of only as unhappy and unnatural. The lesson is illustrated in the Physiologus through the habits of the partridge which steals eggs from other birds. For, once hatched, the kidnapped bird eventually flies off to find its true parents. Similarly, man must 'return to his true father and away from the unnatural parentage which is what terrestrial life is' ${ }^{47}$

In spite of his rationality, any correction in the behaviour of man was only a temporary state of affairs. Terrestrial life remained radically vile and longing was only for death and eternal life. It does not seem that Christians had a happy walk to perfection; life could only be lived in a state of exception and anticipation. Man was rendered low by virtue of his incorrect status and shown to be deficient through the mirror of symbolic animal. Animals were, in other words, a reminder of man's imperfect and abeyant subjectivity.

We might add that in the terminology of the common law, 'abeyance' refers to the principle that interrupts genealogy and inheritance. Property, for example, cannot vest in a named beneficiary until all ancestors or preceding owners die: the maxim nemo est haeres viventis (no one can be heir to a living person) might be taken as a synecdoche of the theological state of waiting for death. Lacanian theory has of course drawn attention to the lack at the heart of subjectivity, and the subject's relation to an impossible object of desire. Christian soteriology conceives of this lack in terms of waiting or preparation, while the object of desire (salvation) becomes key to the manipulation of souls. The humiliation for Christianised man is that his abeyance rests upon a certain sovereign status that stubbornly remains attached to the very natural order he seeks to subjugate.

\subsection{Conclusion}

In allegorising a foundation to which all behaviour is measured, animal literature instigates a break in the relationship between man and animal. The sacred comes to be exteriorised and separated from the environment. Moreover, according to this economy, the symbolisation of the sacred foundation through the figuration of animals further consolidates this breach by cultivating man as distinctly nonanimal endowed with a capacity to read and decode the world. But in directing behaviour towards a definite salvation, animal literature institutes an idea of sovereignty that is defined only in relation to an imagined future salvation. 
The concept of the future initiated by animal didactic literature cannot be understood as the unknowable horizon of a future to come. It cannot be equated in any sense to the radical messianic idea of l'avenir so beautifully explicated by Derrida ${ }^{48}$ Within Christian soteriology everything is known and predetermined. The future becomes the exact spot toward which man must face and progress. Placing the promise of redemption at the core of existence wrought heavy changes in the orientation of man who was to invest both in God the father as well as in a salvation through Christ the Son. Salvation, a spiritual exteriority, a faith in another world, became the foundational requirement that was to give meaning to all social existence. Moreover, the possibility of salvation points to a divine plan according to which the whole political organisation of the church was to conform. Salvation, in other words, instituted a machinery for the terrestrial and political management of an overarching plan. It was after the Gregorian reforms in particular that the general notion of salvation was incorporated into the social programme of Roman law. The Church was to legalise the present saeculum in anticipation of the next world. Thus, for example, given that animals indicated the imperfect nature of man, the whole of secular existence was to be condemned and defined in relation to penal existence; punishment was rationalised to reflect the tripartite distinction between heaven, hell and purgatory. The power over naked life was justified and measured in anticipation of that which the animal and the natural environment were ciphers.

\section{Notes}

1 Berman, 1983: 558.

2 Agamben, 2004.

3 Dedicated to Lila Haldar for her fondness of animal stories. Thanks to Anton Schutz, Peter Goodrich, Elena Loizidou, Andreas Philippopoulos-Mihalopoulos and the participants of the seminar he organised at Westminster University on Critical Environmental Law.

4 Kantorowicz, 1957: 78-86.

5 Kantorowicz, 1957: 85.

6 Job 12:7.

7 Ovid, Metamorphoses; Aesop, Fables.

8 Pliny the Elder, Natural History; Aelian, On Animals.

9 Isidore of Seville, Etymologiae, Book XII.

10 Aristotle, Historia Animalium.

11 The Arbor Porphyriana is a hierarchical method of classifying genus and species. Its modern avatar lies in the field of cladistics.

12 Calvino, 1987: 79.

13 Theobaldus, Physiologus.

14 For more detail on how the Church Fathers legitimated the use of pagan literature see Bradley, 1995: xi-xxiii.

15 Hugh of St Victor, The Didascalion.

16 'And he never shuts his eyes however often he sleeps,' 'De Leone' in Theobaldus, 1972: 27. 
17 A full range of animals, along with their primary sources and their allegorical messages, is to be found at http://www.bestiary.ca.

18 Hadot, 2006: 40.

19 This Heraclitean fragment has been extensively commented upon by Hadot, 2006.

20 Cassian, Collationes Patrum Sceticorum, discussed in Evans, 1896.

21 Jaspers, 1953.

22 Gauchet, 1999: 67.

23 Generally on his theory of ciphers see Jaspers, 1955.

24 Hadot, 2006: 7-28.

25 Paul, Rom. 1:20.

26 Hugh of St Victor, De Triebus Diebus.

27 One such example might be the short-lived punishment under Roman law known as the Poena Culleo. Here the crime of patricide, conceived of as a crime against nature (even the crime against nature), was punished by placing the perpetrator in a leather sack with a cock and a monkey. The sack was then hurled into the sea.

28 Gauchet, 1999: 67.

29 Isidore of Seville, Etymologiae, Book XII, cap. ii, line 6.

30 Richard de Fournival, Bestiaire d'Amour.

31 Job 12:7.

32 Topsell, 1967, a late, perhaps even the last, example of the medieval bestiary. Its heavy Aristotelian style seems to predict the science of zoology.

33 Topsell, 1967: 50.

34 Chapter 1 of this volume.

35 Omnis mundi creatura, 'Quasi liber et pictura:/Nobis est et speculum,' cited in the Latin in Curtius, 1953: 319-26, my translation.

36 Thomas de Cobham, Summa de Arte Praedicandi, ed. F. Morenzoni (Brepols, Turnhout, 1988), p. 275, cited in Camille, 1999: 355.

37 Goodrich, 2006: 27.

38 The original Psychomachia by Prudentius is a purely allegorical poem based on the typological hermeneutics of the virtues and vices; Psychomachia, pp. 274-344.

39 Alciato, Emblematum Liber, Emblem 34, http://www.mun.ca/alciato/.

40 Nietzsche, Thus Spake Zarathustra, iv.4.

41 Lactantius, Carmen de Ave Phoenice, 163-70, reprinted and translated as an appendix in Stanburrough Cook, 1919: 163-70.

42 Codex Exoniensis, ff. 55b-65b reprinted in Stanburrough Cook, 1919.

43 Topsell, 1967, Dedicatory epistle.

44 On the fantasy of Eastern excess see Haldar, 2007.

45 The composite manuscript Cotton Vitellius A. xv contains the texts of Beowulf, along with the Liber Monstrorum, the Epistola Alexandri ad Aristotelem and the Wonders of the East. Each of the texts is reprinted with a translation as an appendix in Orchard, 1995.

46 Evans, 1896: 30.

47 Theobaldus, Physiologus.

48 Derrida, 2000.

\section{Bibliography}

Aelian. 1912. On Animals. Loeb Classical Library, Cambridge MA: Harvard University Press.

Aesop. 1912. Aesop's Fables, trans. Vernon S. Jones. London: Heinemann. 
Aesop. 1998. Aesop: The Complete Fables, trans. Olivia and Robert Taylor. New York: Penguin.

Agamben, Giorgio. 2004. The Open. Stanford CA: Stanford University Press.

Agamben, Giorgio. 2007. 'In praise of profanation', in Profanations, trans. Jeff Fort, New York: Zone Books, pp. 73-92.

Alciato, Andrea. Emblematum Liber, Emblem 34, in Alciato's Book of Emblems, the Memorial Web Edition in Latin and English. http://www.mun.ca/alciato/e034.html. Accessed 2008.

Aristotle. 1984. Historia Animalium. 10 vols, Loeb Classical Library, Cambridge MA: Harvard University Press.

Atterton, Peter, and Matthew Calarco. 2004. Animal Philosophy: Ethics and Identity. London: Continuum.

Augustine. Civitas Dei, xvi.viii.

Bartholomaeus Anglicus. 1260. De propietatibus rerum.

Bataille, Georges. 2008. The Cradle of Humanity: Prehistoric Art and Culture. New York: Zone.

Baxter, Ron. 1998. Bestiaries and their Users in the Middle Ages. London: Sutton.

Berman, Harold. 1983. Law and Revolution: The Formation of the Western Legal Tradition. Cambridge MA: Harvard University Press.

Bradley, S. A. J. 1995. Anglo-Saxon Poetry. London: Dent.

Bumper Development Corporation Ltd v Commissioner of Police of the Metropolis and others (Union of India, claimants) [1991] 4 All ER 638-49.

Calvino, Italo. 1987. 'Man, the sky and the elephant: on Pliny's Natural History' in On Nature; Nature, Landscape and Natural History, ed. Daniel Halpern. San Francisco: North Point Press, pp. 70-79.

Camille, Michael. 1999. 'Bestiary or biology? Aristotle's animals in Oxford, Merton College MS 271', in Aristotle's Animals in the Middle Ages and Renaissance, ed. Carlos Steel et al. Leuven: Leuven University Press.

Cohen, Esther. 1986. 'Law, folklore and animal lore', Past and Present 110: 6-37.

Curtius, Ernst Robert. 1953. European Literature and the Latin Middle Ages. New York: Harper \& Row.

Derrida, Jacques. 2000. Of Hospitality. Stanford CA: Stanford University Press.

Epiphanius. Sancti epiphianii ad physiologum.

Eucharius. Liber formularium.

European Convention on Human Rights, Article 9.

European Council Directive 77/391/EEC.

Evans, Edward Paysan. 1896. Animal Symbolism in Ecclesiastical Architecture. London: Heinemann.

Friedman, John. 1981. The Monstrous Races in Medieval Art and Thought. Cambridge MA: Harvard University Press.

Friedman, John. 1989. 'The marvels-of-the-East tradition in Anglo-Saxon art and thought' in Sources of Anglo-Saxon Culture, ed. Paul Szarmach. Kalamazoo MI: Medieval Institute Publications.

Gauchet, Marcel. 1999. The Disenchantment of the World: A Political History of Religion, trans. Oscar Burge. Princeton NJ: Princeton University Press.

Gesner, Konrad. 1551-87. Historia animalium. Zurich.

Goodrich, Peter, Lior Barshack and Anton Schutz, eds. 2006. Law Text Terror: Essays for Pierre Legendre. London: Glasshouse. 
Goodrich, Peter. 2006. 'A Theory of the Nomogram' in Peter Goodrich, Lior Barshak and Anton Schutz, eds. Law Text Terror: Essays for Pierre Legendre. London: Glasshouse.

Gravestock, Pamela. 1999. 'Did imaginary animals exist?' in The Mark of the Beast: The Medieval Bestiary in Art, Life and Literature, ed. Debra Hassig. New York: Garland.

Hadot, Pierre. 2006. The Veil of Isis: An Essay on the History of the Idea of Nature, trans. Michael Chase. Cambridge MA: Harvard University Press.

Haldar, Piyel. 2007. Law, Orientalism, Postcolonialism: The Jurisdiction of the Lotus Eaters. New York: RoutledgeCavendish.

Hassig, Debra. 1995. Medieval Bestiaries: Text, Image, Ideology. Cambridge: Cambridge University Press.

Herodotus. Histories.

Hugh of St Victor. De Triebus Diebus.

Hugh of St Victor. The Didascalion.

Isidore of Seville. 2006. Etymologiae, Book XII. Cambridge: Cambridge University Press.

James, M. R., ed. 1928. The Bestiar, being a Reproduction in full of MS. Ii 4. 26 in the University Library, Cambridge, with Supplementary Plates from other Manuscripts of English Origin, and a Preliminary Study of the Latin Bestiary as current in England. Oxford: Roxburghe Club.

Jaspers, Karl. 1953. The Origin and Goal of History. London: Routledge.

Jaspers, Karl. 1955. Reason and Existenz. New York: Noonday Press.

Julius Gaius Solinus. De mirabilis mundi.

Kantorowicz, Ernst. 1957. The King's Two Bodies: A Study in Medieval Political Theology. Princeton NJ: Princeton University Press.

Lactantius, Carmen de Ave Phoenice, 163-70, repr. and trans. in Stanburrough Cook, The Old English Elene, Phoenix and Physiologus. New Haven CT: Yale University Press, 1919.

Mondzain, Marie-Jose. 2003. Image, Icon, Economy. Stanford CA: Stanford University Press.

Nietzsche, Friedrich. 1887. On the Genealogy of Morals. Oxford: Oxford University Press, 1996.

Nietzsche, Friedrich. 1954. Thus Spoke Zarathustra, trans. Walter Kaufmann. New York: Penguin.

Orchard, Andy. 1995. Pride and Prodigies: Studies in the Monsters of the Beowulf Manuscript. Cambridge: Brewer.

Ovid. Metamorphoses.

Pliny the Elder. Natural History.

Porsia. Liber monstrorum.

Prudentius. Psychomachia, in Prudentius, Vol. 1, Loeb Classical Library. Cambridge MA: Harvard University Press, 1993.

$R$. (Williamson) v Secretary of State for Education and Employment (2005).

Richard de Fournival. 1986. Bestiaire d'amour in Master Richard's Bestiary of Love and Response, trans. Jeanette Beer. London: University of California Press.

Sayers, Dorothy L. 1987. Gaudy Night. London: Hodder \& Stoughton.

Stanburrough Cook, Albert., ed. 1919. The Old English Elene, Phoenix and Physiologus. New Haven CT: Yale University Press; London: Humphrey Milford. 
The Aberdeen Bestiary. Aberdeen University Library MS 24.

The Ashmole Bestiary. Bodleian MS Ashmole 1511.

Theobaldus. 1972. Physiologus, ed. P. T. Eden. Leiden and Cologne: Brill.

Thomas de Cobham. 1988. Summa de arte praedicandi, ed. Franco Morenzoni. Turnhout: Brepols.

Thomas of Cantimpre. Liber de natura rerum, 1230-45.

Topsell, Edward, ed. 1967. The History of Four-footed Beasts and Serpents and Insects, describing at large their True and Lively Figure, their several Names, Conditions, Kinds, Virtues (both Natural and Medicinal) Countries of their Breed, their Love and Hatred to Mankind, and the wonderful Work of God in their Creation, Preservation and Destruction, taken principally from the Historiae Animalium of Conrad Gesner, 3 vols. London: Frank Cass.

Tsedek v France, 2000, European Court of Human Rights.

Wittkower, Rudolf. 1942. 'Marvels of the East: a study in the history of monsters', Journal of the Warburg and Courtauld Institutes 5: 159-97.

Wooton, Edward. 1552. De differentiis animalibus libri decem. Paris. 


\title{
Seeking spatial and environmental justice for people and places within the European Union
}

\author{
Antonia Layard and Jane Holder
}

\section{I Introduction}

This chapter ${ }^{1}$ explores the interaction between solidarity, territorial cohesion and environmental justice within the EU. It considers how the spatial focus at the heart of territorial cohesion, and the funding streams attached, now provide a novel and significant way to address environmental inequality. This is premised on the notion of solidarity between people and places within the territory of the EU. Taken together, environmental justice, territorial cohesion and spatial solidarity embrace a common core: they all suggest that location should not be a disadvantage. Relying on the still inchoate and contested concept of territorial cohesion, policy makers and advocates are able to extend their claims still further. They are able to use cohesion funding, treaty provisions and legal prescriptions to pursue environmental justice in situ, creating positively 'just environments' from the ground up. This provides a novel and exciting way to seek spatial and environmental justice for both people and places within the EU.

Environmental law is spatially situated. Its 'stuckness'2 ensures that the qualities of each site are as significant to environmental regulation as the nature of the regulated activity itself. Each determination must ultimately be made in situ, evaluating how activities and uses impact upon humans, other species, habitats or ecosystems. This spatial understanding of environmental law patterns EU environmental law in particular. We see it, for example, in Natura 2000, ${ }^{3}$ with its network of protected sites, conceived of as a series of pan-European ecological places. Similar place-making underpins the use of spatial units as the foci for public governance, particularly the river basin management at the heart of the 2000 Water Framework Directive ${ }^{4}$ and the focus on individual European seas that underpins the 2007 Marine Strategy Framework Directive. ${ }^{5}$ It is inherent in the drawing of nitrogen vulnerable ${ }^{6}$ and air quality management ${ }^{7}$ 'zones' where environmental obligations are imposed differently either side of the line. Perhaps most significantly of all, this rolling out of environmental law on an explicitly spatial basis is increasingly underpinned by the funding at the heart of EU regional policy. Here $€ 105$ billion has been allocated to the 
'green economy'8 including $€ 8.7$ billion allocated to territorial co-operation ${ }^{9}$ with the 'flagship' Baltic Sea Strategy, which itself draws on over $€ 50$ billion of cohesion funds. ${ }^{10}$ These strategies provide spatial form to integrative and holistic projects that address environmental concerns within boundary lines.

At the heart of this regional place-making activity is the concept of 'territorial cohesion', an idea that remains subject to multiple and contested definitions. Its goal has been formulated by the Commission as encouraging 'the harmonious and sustainable development of all territories by building on their territorial characteristics and resources' ${ }^{11}$ This calls on principles of economic liberalism as well as drawing on 'harmonisation', importing a form of coherence and equivalence and placing the concept firmly within the EU's pantheon of integrated policy and decision-making. The interpretation is underpinned by the new coupling in Article 3 of the Treaty on the European Constitution, requiring the Union to "promote economic, social and territorial cohesion' as well as the pursuit of 'solidarity'. ${ }^{12}$ These strands of territorial cohesion and solidarity are drawn together in a growing, and rather explicit, territorial project: the creation of the idea of a Single European Territory. This notion is fostered by the many references in policy documents to 'the Territory of the EU' as a given physical reality. ${ }^{13}$

This spatial delineation of EU territory draws on a normative core in favour of European integration and increasingly on an idea of what the 'Union' entails. Central to these normative claims is the reliance on 'solidarity', a concept that has for some time now lain at the core of the EU's embryonic social welfare project yet remains largely unarticulated and frequently rhetorical. While the draft of the Treaty on European Union proposed solidarity between 'Member States and their peoples', the solidarity between people was ultimately relegated to the non-binding, preambular provisions: Article 3 now calls only for solidarity 'between Member States'. Still, in the absence of legal precision the historical and political antecedents of the idea of solidarity remain. It is a principle that hints at communality and demos, those fraught ideas within the EU predicated on an understanding of common interest. Within the EU Treaties and other texts, solidarity has both an internal and an external dimension characterising aspects both of relationships within the European Union and of the EU's relations with the outside world. ${ }^{14}$ It is not an idea that necessarily needs to end at the borders of the EU.

Moreover, solidarity can exist not only between Member States and people but also, and significantly in light of the objective to achieve territorial cohesion, between places. This spatial component is often emphasised by the linking of both solidarity and territorial cohesion with a commitment to provide 'services of general economic interest', reflecting an understanding by French regional planners of territorial cohesion as founded in support for communities that perpetuate a preferred understanding of place. This represents a French interest in pursuing redistributive policies within a regional context, the so-called aménagement $d u$ territoire. Such intervention is based not merely on relative 
GDP (as in EU cohesion policy) but is rooted within the French administrative model. This reflects a cultural dimension. 'Europeans, it is argued, are rooted in the soil ... In their desire to continue to live where they have for generations they deserve public support. ${ }^{\text {'15 }}$ This understanding of territorial cohesion as at least partly a cultural mechanism evokes a more emotive landscape than the technical provisions inserted into EU policy-making as a desire to protect the peripheries of the EU. Article 174 of the TFEU focuses on geographical difference, requiring cohesion policies to 'pay attention' to 'rural areas, areas affected by industrial transition, and regions which suffer from severe and permanent natural or demographic handicaps such as the northernmost regions with very low population density and island, cross-border and mountain regions'.

Compared with solidarity, the idea of cohesion is more clearly understood within EU parameters, primarily through the projects it provides. It is a vehicle for funding, one that has long struggled to balance the apparently twin objectives of competitiveness and wealth production on the one hand and social cohesion and convergence on the other with a budget that is set to exceed that for agriculture by 2013. Despite this extensive funding, there is an inherent tension here in that while both the twin objectives of stimulating economic growth and competitiveness and of addressing low levels of wealth and resources both aim at improvement, 'one is about winners and losers while the other is about redistribution'. ${ }^{16}$ Nevertheless, these multiple objectives are translated into the contested and still unformed concept of territorial cohesion that draws on strands of both existing cohesion policy and its legacy in integrative spatial planning, making both emotive and technical claims. While the substantive legal acquis may remain fragmented, cohesion funding, particularly as channelled through the 'territorial co-operation' objective, has the capacity to transform the idea of territorial cohesion into more than merely a territorial dimension to existing social and economic policies on cohesion. Territorial cohesion coupled with a sense of solidarity aims, as the Third Cohesion Report put it, to ensure that: "people should not be disadvantaged by wherever they happen to live or work in the Union' ${ }^{17}$ This embraces a spark of spatial justice, ${ }^{18}$ suggesting that there could be solidarity between both people and places. Solidarity as a normative claim is underpinned by the practice of cohesion: both are attempting to reduce disparities between people and places within the territory of the EU.

This coupling is significant for environmental law and claims for environmental justice in particular since regional policy has a growing, yet often rather under-appreciated, ${ }^{19}$ environmental strand. The intervention of an EUwide conception of solidarity and a drawing on the funding streams within cohesion policy to achieve these integrative aims is becoming increasingly significant as a new way 'to do' environmental law. Cohesion policy already provides environmental funding 'carrots' to supplement regulatory 'sticks', and has already been instrumental in ensuring greater and more effective implementation of environmental law. 
Now, and perhaps even more significantly, cohesion policy is beginning to influence environmental law in an explicitly spatial way. Cohesion policy has itself been spatial from the outset, dividing up Member States by using the nomenclature of territorial statistics into NUTS 2 regions and then comparing them by reference to economic, employment and other, quantifiable, markers. The funding cohesion policy entails and the place-making projects regulators increasingly support, coupled with the inescapably spatial quality of environmental law, creates real possibilities for the environmental justice project within the EU. ${ }^{20}$ This movement reflects the broad consensus that, despite aspirations to pollution prevention and reduction, harm cannot be eradicated: there is no imminent prospect of an ecotopian state. ${ }^{21}$ Accepting this reality, the environmental justice project raises the question of how environmental risks and harms should be spatially distributed, calling on politicians, administrators and developers to ensure that if exposures cannot be eliminated entirely that they are in some way proportionate. Taken together, the concepts of territorial cohesion, spatial solidarity and environmental justice embrace a common core: they all suggest that location should not be a disadvantage and that sustainable places should be formulated from the ground up within a common environmental acquis.

This is a particularly significant claim for environmental law, itself always spatially situated but now increasingly cognisant of that fact. Law has conventionally accepted that geography may restrict liability in certain contexts: that location is relevant to determining legal harm to amenity and 'what is a nuisance in Belgravia may not be such in Bermondsey' (Sturges v. Bridgman (1879) 11 Ch.D. 852). The substantive premise at the heart of environmental justice is that spatially differentiated exposure to the risk of environmental harm should not exist, even if it has not yet crystallised into liability. While environmental justice has conventionally been conceptualised as a humancentred harm, it is fundamentally a collective concern bound to location. ${ }^{22}$ Pursuing environmental justice claims grounded in locality, not only entails the harmonisation of substantive standards which continues to remain at the heart of the EU's environmental law project, it also balances the inherent 'stuckness' of environmental law with claims for equality and coherence. The spatial focus at the heart of territorial cohesion, and the funding streams attached, now provide a novel and significant way to address environmental inequality premised on the notion of solidarity between people and places within the territory of the EU. It uses funding, treaty provisions and legal prescriptions to pursue environmental justice in situ.

\subsection{Territorial cohesion and environmental justice}

The pursuit of environmental justice through the concept of territorial cohesion accepts the central tension at the heart of cohesion policy that the disparity cohesion aims to redress is itself an inevitable consequence of 
enhanced competition which its programmes aim to promote. ${ }^{23}$ Recently cohesion policy has attempted to reconcile this dilemma by invoking the centrality of economic growth - translated into cohesion policy as an emphasis on 'unlocking' potential. ${ }^{24}$ Actors developing cohesion policy have taken up the idea of territory to try and resolve the dissonance between competitiveness and redistribution, echoing OECD policy to emphasise the role of place-based policy approaches in capitalising on territorial assets and locational advantages such as knowledge, skills, specialisation and proximity between economic agents. ${ }^{25}$ This coordination and repackaging has created a new policy language ('territorial cohesion', 'territorial capital', 'territorial assets') supported and communicated by a new (and still shifting) vocabulary, developing an array of acronyms, symbols, metaphors, maps, texts, 'visions and scenarios', and implemented by new 'knowledge building' institutional structures and the setting up of policy networks. The language here is one of territory rather than spatiality: backed up by significant EU funds, this is a place-making project creating a political and spatial vision of the territory of the EU.

Specifically, there is a suggestion that this concept of territorial cohesion, now inserted into Article 3 of the Treaty EC, gives a territorial dimension to the European social model. If true, this would be a tantalising possibility: suggesting that territorial cohesion extends the idea of a 'European social model' into spatial form, incorporating concerns about spatial protection by calling for 'a just distribution of opportunities in space'. ${ }^{26}$ Both politicians and the Commission have suggested such a link ${ }^{27}$ agreeing, for example that 'territorial cohesion of the EU is prerequisite for achieving sustainable economic growth and implementing social and economic cohesion - a European social model' ${ }^{28}$ There is political support for Davoudi to suggest that territorial cohesion is not only rooted in the European model, it also 'extends its affiliation with social-protection to incorporate concerns about spatial-protection'. ${ }^{29}$

Yet allying territorial cohesion to a political model as an empirical observation requires a stable and agreed model of European society in order to have logical force. In political terms, the European social model is often attributed to the European vision espoused by Jacques Delors and was referred to in both the 1994 White Paper on Social Policy ${ }^{30}$ and the Lisbon Presidency conclusions before being more fully articulated in an annex to the Presidency Conclusions in Nice in 2000 as being 'characterized in particular by systems that offer a high level of social protection, by the importance of the social dialogue and by services of general interest covering activities vital for social cohesion'. ${ }^{31}$ The model, it was said, is based 'beyond the diversity of the Member States' social systems, on a common core of values'. ${ }^{32}$ Presented thus, these criteria go beyond social policy, to include characteristics of state, economy and society. ${ }^{33}$ Yet there is consistent agreement that 'the notion of the "European social model" is misleading, ${ }^{34}$ that it is contested 
and hortatory, with empirical heterogeneity undermining claims of a 'historical acquis' ${ }^{35}$ Some have characterised the concept as being best understood as a political project used by the European institutions to increase their own legitimacy. ${ }^{36}$

If the social model is this uncertain can it then be spatialised? European planning traditions are diverse ${ }^{37}$ and proponents have offered no explanation of how the social model itself is affected by concrete practices in spatial development policy. ${ }^{38}$ Consequently, as an empirical observation it is hard to maintain that territorial cohesion is rooted in the European social model if no single model can be definitively identified. Certainly, as a normative claim that the European social model should encompass a core of shared values which when spatialised would promote spatial justice, territorial cohesion provides an effective vehicle, particularly when allied to the emphasis on universal access inherent in the protection of services of general public interest under the Treaty. Furthermore, as Faludi explains, territorial cohesion should also include a visionary element. Such spatial visions 'must conceive of towns and cities and regions, indeed of the territory of the EU as a whole, as more than places of production'. He continues, '[T]erritories need to be conceptualized as cohesive ... People should want to attach themselves to territories. Indeed where the process is conducted in transparent fashion, the very act of visioning territories and their futures can contribute to this feeling of attachment' ${ }^{39}$ Faludi's vision might be described as a type of territorial solidarity, with a sense of identity with a territory being forged by the very process of being involved in deliberation about its future structure, linkages and shape.

Moreover the way the EU is being spatialised emphasises a single EU territory within which there is a central normative claim for solidarity which could form part of an accepted acquis whether or not this can be categorised as a unitary European social model. This is significant for environmental justice since it has often focused on individual interests, particularly in a corrective context, even though it is essentially a communal, spatial project. There are good reasons for this: legal mechanisms have often obscured the relevance of any collective interest, for example, formulating corrective justice in terms of individual rights or restricting the ability of NGOs to question the legitimacy of environmentally harmful decisions, even those implemented with cohesion funds. ${ }^{40}$ Increasing administrative and legislative inclusion (particularly, but not limited to, initiatives introduced in light of the Åarhus Convention $^{41}$ ) operate in sharp contrast to the judicial intransigence in allowing environmental NGOs access to justice. ${ }^{42}$ Environmental law has consistently struggled to conceptualise the collective interest, particularly in litigation, preferring to consider the interests of individuals and the concerns of the state. The introduction of territorial cohesion is significant then in that it offers new scope to focus on places (collective physical or spatial entities) as well as people, spatially reframing and rescaling the environmental justice debate at the EU level. 
These possibilities for environmental justice emerge as a direct consequence of both the tentative promotion of a claim for EU-wide solidarity and the way territorial claims are being made for, and within, the EU. While the environmental legal acquis is increasingly well developed, it is marked by a trend towards flexibility and managerialism, and rhetorical proceduralisation. ${ }^{43}$ Simultaneously, the recent Treaty alterations and documents outlining the development of the territorial cohesion concept demonstrate a growing desire to minimise differences in living conditions between places within a framework that stimulates growth and economic development. Environmental law has become more open-textured, in part because a growing recognition that it necessarily takes place in situ means that administrators on the ground need the ability to implement laws flexibly, ${ }^{44}$ particularly when developing programmes for conservation, synergistic pollution assessments or determinations of aquatic ecological quality or quantity. ${ }^{45}$ There is clearly an overlap between the desire within regional policy to improve quality of life and the efforts of environmental law to promote local environmental quality.

There remains a danger that the intervention is more rhetorical than real. As Pellegrin writes in the cohesion context, attempts to reconcile apparently contradictory objectives often illustrate 'one feature specific to policymaking at EU level, namely that solutions to contradictions are often more discursive than real. Stating that there is no contradiction resolves the contradiction, and naming the solution becomes the solution. ${ }^{46}$ Such a rhetorical, yet ultimately amorphous, understanding of solidarity can already be identified in the Treaties. ${ }^{47}$ Yet a claim for environmental justice within the context of regional policy can draw on the concept's multiple strands (distributional, procedural, corrective and social) to suggest that there are alternative ways to balance the benefits of economic development and differential exposure to both environmental 'goods' and 'bads' within the EU. The largely unarticulated concept of solidarity provides the key to translate this desire for equivalence between people and places into reality, particularly when coupled with such large tranches of cohesion funding. This possibility is prefigured in the ability of Member States to provide 'services of general economic interest' to citizens, despite the murky legal waters this produces when viewed in the context of EU competition rules and prescriptions on state aid. ${ }^{48}$ In summary, the EU project has always been about more than economic liberalism and these interactions are increasingly recognised as spatial tensions as well as political and normative disputes.

\subsection{Environmental justice in the European Union}

The call for environmental justice began in the 1970s in the United States when community activists highlighted environmental degradation in their neighbourhoods resulting from 'locally undesirable land uses' ${ }^{49}$ While always 
grounded in place, the US environmental justice movement built on a strong civil rights tradition, combining the force of constitutional protection with concerns for substantive environmental quality. The central claim often elided the interests of communities and individuals, for example Bullard, a leading proponent of claims for environmental justice, argued both that environmental justice is the principle that 'all people and communities are entitled to equal protection of environmental and public health laws and regulations' ${ }^{50}$ and that everyone should have the right to live in a healthy environment with access to enough environmental resources for a healthy life. ${ }^{51}$ This emphasis on individual rights was frequently articulated within the historical and political narrative of civil rights, allying the US movement closely with questions of race and the production of 'environmental racism'. ${ }^{52}$ It was this that led to two characteristic debates within claims for environmental justice: first, the question of 'class versus race', ${ }^{53}$ and second, a debate questioning the correct scale to determine inequity. ${ }^{54}$

Despite the lobbying efforts of individual NGOs and an abundant awareness of environmental justice concerns amongst European scholars, there is within the EU no systematic attempt to link social status, race or ethnicity to environmental risk exposure. ${ }^{55}$ While academics are beginning to engage with the demands of environmental justice in many European states ${ }^{56}$ they note a general lack of institutionalised consideration of these issues, even characterising the concept as 'the Anglo-American concept of environmental justice'. ${ }^{57}$ Certainly, within Europe, the most systematic developments have taken place within the United Kingdom, particularly in Scotland. ${ }^{58}$ The European Environment Agency has recognised only that the 'environmentrelated share of the burden of disease ... depends strongly on socio-economic aspects such as income, the share generally being higher in lower-income countries' ${ }^{59}$ Significantly, however, an important and growing body of work is being undertaken by the World Health Organisation (WHO) in Europe, focusing particularly on the impact of environmental inequity on children. ${ }^{60}$ Scientists have argued to the WHO that environmental justice needs to be taken at both the strategic and the local scale since their evidence raises concerns that ' $[\mathrm{m}]$ arginalized and disadvantaged groups may be disproportionately exposed and vulnerable to environmental risks through a range of mechanisms including limited financial resources facilitating risk reduction, hazardous or unprotected work, or poor and unsafe living conditions worsened by social segregation and stigma'. ${ }^{61}$

As in the United States, there may be a good fit between environmental disparity and racial and ethnic considerations rather than solely being predicated on social class. ${ }^{62}$ This 'race versus class' debate is relevant in the EU as well. ${ }^{63}$ Academic research here is still incipient, but Harper et al. ask rhetorically: "Why is it that Roma shanty towns are frequently located next to landfills, on contaminated land, or that they are regularly exposed to floods? Why do water pipelines end on the edges of predominantly Roma 
settlements, so that people have to walk miles every day just to collect potable water for cooking and drinking?' They argue that 'when some landscapes and social groups are perceived as "beyond the pale" of environmental regulation, public participation and civil rights, it creates local sites for externalizing environmental harms'. ${ }^{64}$ These concerns are clearly integral to all strands of environmental justice, including access to decision-making. Given the socially situated nature of many environmental justice concerns, in addition to measures reviewing equity of siting, there should also be an 'ongoing role for community participation in all decisions that fundamentally affect the participants' lives'. ${ }^{65}$

In practice, any analysis of environmental justice as simply the spatial distribution of environmental risks has from the outset been characterised as too narrow an approach. Distinctions have long been made between procedural, geographic and social environmental justice assessing how access to decision-making, socio-economic factors and environmental harm are all intertwined ${ }^{66}$ In particular, the procedural strand of environmental justice, focusing on public participation and access to decision-making was central to claims of environmental justice from the outset, ${ }^{67}$ enabling groups and individuals to question why actually or potentially polluting facilities were more densely located in poorer, less influential, residential locations. This procedural strand has become an increasingly influential element in the debate ${ }^{68}$ assessing the ability to contribute to decision-making, obtain access to information and the ability to bring legal challenges. Indeed, amongst some lawyers, environmental justice has been formulated primarily in terms of access to (legal) justice. ${ }^{69}$ This focus has led to notable successes, in particular the conclusion of the 1998 Aarhus Convention, ${ }^{70}$ with its three pillars of access to information, public participation in environmental decision making and access to justice. As a result, throughout the EU, wherever people are located, they have legal rights to gain access to environmental information and to be involved in decision-making, particularly through the environmental assessment procedures when new projects are developed. The actual effectiveness of such involvement, in the context of continuing social and political influences and factors, remains of course highly contested.

Indeed, the third Aarhus pillar, aimed at facilitating the making of legal claims for environmental redress has proved extraordinarily contentious and has still to be brought into effect in the EU. This form of 'corrective environmental justice' was also a later addition in the United States, ${ }^{71}$ particularly under Title VI of the US Civil Rights Act $1964^{72}$ and is a significant strand of claims for environmental justice. It has been considered in the context of infringed rights by the European Court of Human Rights (ECtHR). Initially, the ECtHR seemed to take distance effectively as a proxy for causation: in Lopez Ostra v Spain ${ }^{73}$ for example, the Court declined to engage in a causal analysis, emphasising instead 'the fact that the applicant and her family lived for years only $12 \mathrm{~m}$ away from a source of smells, noise and fumes'. The Court saw an obvious link between location and violation, 
framing Article 8, the right to a home, as an environmental right in the context of location. In Lopez Ostra the ECtHR held that 'naturally, severe environmental pollution may affect individuals' well-being and prevent them from enjoying their homes in such a way as to affect their private and family life adversely, without, however, seriously endangering their health'. While in the more recent decisions in Fadeyeva v Russia ${ }^{74}$ and Tatar v Romania ${ }^{75}$ the Court has taken a more stringent approach to proving causation in terms of ill health, in both cases it found a breach of the right to private life and home by virtue of living so closely to an acknowledged environmental harm. Both concerned particularly egregious sets of facts and were thus able to scale the 'high threshold' of environmental harm required by the ECtHR. While the relevance and significance of residential location is recognised, ultimately an action to the ECtHR will lie only in the most exceptional of cases.

One way to move from individuals to collective concern has been to introduce the idea of 'social' environmental justice, assessing the impact of economic marginalisation, race, ethnicity, class, culture, lifestyles and political power in environmental decision-making. ${ }^{76}$ As Martuzzi et al. have noted in their review of the siting of waste facilities on health: 'there is a tendency in poorer, less educated, disadvantaged people or ethnical minorities to live closer to waste treatment facilities of any kind and, in addition, that when adverse health effects due to such proximity are detected, these are often compounded (usually multiplicatively) with the adverse effects of social disadvantage'. ${ }^{77}$ In this context it is possible to dismiss claims of environmental inequity as simply part of a broader understanding of social inequity or to suggest that to focus on environmental concerns is to miss opportunities for much-needed economic development. Yet this engages arguments of spatiality and scale. When, for example, a local campaigning group, supported by the national NGO Friends of the Earth, drew attention to the potential toxicity in Hartlepool of 'ghost ships' in a marine breaking yard that had won a $£ 10.6$ million contract to recycle the steel and dispose of the pollutants from ex-US Navy auxiliary vessels, the activists' concerns were rejected as being too insular. The real concern, as successfully framed by the company that owned the yard and parts of the national media, was the economic development this remediation would bring to the region and the far greater safety risks workers would face in other parts of the world if they were to dismantle these ships there. Ultimately the company and the national media won the legal argument, redrawing the issue from a local to a regional scale. In practice, scale framing was used by both sides in enrolling allies, building relational power and achieving set political ends. As Agyeman and Bickerstaff note, 'the scaling of injustice ... is an integral part of strategies of empowerment and disempowerment'. ${ }^{78}$

It is this rescaling, long familiar to advocates for environmental justice ${ }^{79}$ that is now being implemented at EU level. Territorial cohesion provides a new regional focus for environmental justice, a level at which some NGOs 
have already specifically decided to engage. ${ }^{80}$ Framing environmental justice as a concern throughout the territory of the EU, by recognising its inherent spatiality, places it squarely within the remit of principles of territorial cohesion and solidarity, empowering individuals and communities as well as places. If through funding or delineation these spatial units are conceptualised as 'EU places' then examples of best practice in one part of the region provide political and philosophical leverage to argue that standards should be the same throughout. The very idea of EU places is underpinned by understandings of cohesion and solidarity extending throughout the territory of the EU. A call for spatial justice is a normative claim rather than an empirical observation, yet it is one that can be crafted within the narrative of cohesion funding to focus on a place-based interpretation of environmental justice that focuses on both social and environmental concerns of both people and places.

\subsection{A new EU paradigm for a place-based interpretation of environmental justice}

For environmental law this raises the question whether claims for environmental justice within the EU, characterised by principles of solidarity and territorial cohesion and working within an acknowledged spatial environmental law, offer any hope to alter 'business as usual'. Does the conceptualisation of territorial cohesion as importing a sense of spatial justice or territorial solidarity have the potential to bring environmental justice into closer reach? Or does it still perpetuate the differential allocation of both environmental goods (access to clean water, sufficient energy and places of nature conservation) and bads (risks of environmental damage, pollution, degradation of amenity and place)?

One highly effective way to improve environmental quality is to continue the environmental law project on harmonisation and cohesion funds that already focuses intensely on implementation. The sums involved are significant. In the third (2000-06) budget cycle cohesion funds provided for (supplemented by Member State funds in accordance with the principle of additionality) 828 environmental projects with an average project cost of $€ 29.5$ million that included 266 waste-water projects, 190 urban/industrial waste projects and 127 water supply projects as well as 294 transport projects, 113 of which were rail projects and 104 road projects. ${ }^{81}$ This was set to be exceeded in the fourth (2007-13) budget cycle, which has allocated $€ 133$ million to the 'green economy', including implementation for environmental protection. This is coupled with a growing awareness of the importance of evaluating the environmental impacts of cohesion projects ${ }^{82}$ and together the European Environment Agency and the European Network of Environmental Authorities have begun to create a framework for ex post evaluation of the negative effects of structural and cohesion funding on the 
environment. The interrelationship of the Lisbon Strategy and the Sustainable Development Strategy is clearly making its mark, with the EEA emphasising the EU Sustainable Development Strategy's call to gradually eliminate environmentally harmful subsidies, criticising, for example, the fact that 'road projects across the EU continue to receive disproportionate funding compared to other more environmentally friendly investments' ${ }^{83}$ These projects address some of the substantial failures to implement environmental legislation within the EU, where initially 'a conspiracy of silence prevailed'84 about non-compliance, which has beset old and new Member States alike. ${ }^{85}$

These existing initiatives are now supplemented with new opportunities to pursue spatial environmental justice through the concept of territorial cohesion, which suggests that location should not be a disadvantage. Such a formulation of spatial environmental justice is congruent with the holistic, integrative approach that territorial concerns bring to cohesion policy and the requirements of sustainable development, particularly an interpretation of sustainable development working alongside a principle of solidarity. Seriously engaging solidarity as a principle for guiding thinking about territorial cohesion and its implementation in policy, beyond the solidarity conditions for equality of access to services and equal participation in entrepreneurial activity, would suggest the need for some reframing of the concept to include ideas of interdependence, shared responsibilities and burdens and even redistribution, but, most important, the possibility of sharing a set of common values - as well as 'concerns' - at the EU level. This extends the concepts of solidarity and territorial cohesion to environmental concerns: reflecting that notwithstanding the presence and perception of 'competitive Europe', ' ... the Europe of solidarity and co-operation already exists, embodied in the economic and social cohesion policy'. ${ }^{86}$ From this perspective, territorial cohesion and territorial co-operation - and perhaps territorial solidarity can still give a new impetus to EU integration, not as an abstract ideal, but as the best way to pursue the common good of all EU citizens.

This more holistic, integrative approach to cohesion is clearly compatible with a philosophy of social environmental justice applied beyond the urban pollution context, extending to the ability to access environmental 'goods', for example, under the 'right to roam', ${ }^{87}$ access to decision-making in respect of natural resources such minerals or forestry ${ }^{88}$ and access to essential environmental services, including electricity, clean water or sanitation. ${ }^{89}$ In this context it is worth remembering that there are still an estimated 100 million Europeans (not all within the EU) without access to safe drinking water and adequate sanitation. ${ }^{90}$ Environmental justice claims must reflect their locality and there is growing acceptance that the content of environmental justice will be at least partly locally dictated, that it is 'as a concept and practice ... locally grounded' and cannot be universalised even though 'the local definition and use of the term are dependent on its construction at a variety of scales'. ${ }^{91}$ The aim here is to work backwards, considering what 'just sustainability' ${ }^{92}$ might entail in situ. 
These calls for a spatially and socially situated form of environmental justice interpret environmental inequity as part of the broader pattern of difference and differentiation. While EU regulators must remain alive to inequalities in siting, especially where because land is cheap or resistance is limited, there is a real opportunity to use cohesion policy to try to build 'just environments' ${ }^{93}$ from the ground up. There is a clear overlap here between social and environmental concerns: empirical evidence suggests that the 'everyday concerns' of environmental justice can include fuel poverty, lack of safe outdoor space, social exclusion and concern about pollution. ${ }^{94}$ Cohesion funding is well placed to adopt a holistic approach; the premise of differentiation that underpins funding allocation and the principle of solidarity that is closely allied to cohesion's rationale provides ample political and philosophical support for intervention.

Lastly, but significantly, if environmental justice is conceptualised as a means of comparing and improving environmental conditions between places, then a procedural strand would play a part in this. ${ }^{95}$ The US place-based discourse of civic environmentalism holds some possibilities here in its focus on local, devolved decision-making engaging with local communities particularly to make land use decisions, often relating to natural resources, that are themselves at the root of some of the most intractable environmental problems. ${ }^{96}$ While civic environmentalism is not limited to conflicts between private property values and public values, these are typically the situations in which top-down regulation loses broad popular support and civic environmentalism may have a role to play. ${ }^{97}$ In the United States there is genuine excitement about the potential for collaborative land management to stimulate local civic engagement in environmental affairs, ${ }^{98}$ where participants are said to transform their affection and local knowledge of a place into a force for sustained change. Its strength is said to lie 'in tapping the creative abilities of citizens to solve the problems of a place that matters to them' ${ }^{99}$

Yet as with all participatory mechanisms, involvement can only be effective if barriers to participation are truly overcome. ${ }^{100}$ Possibilities for participation and involvement need to challenge the interests of decision-making and environmental elites who have traditionally not included the more excluded communities or individuals. ${ }^{101}$ Civic environmentalism is itself limited by the disparate resources available to developers and local stakeholders ${ }^{102}$ and the difficulty of applying its tenets to large-scale, complex environmental problems. ${ }^{103}$ Like environmental justice, the civic environmentalism discourse has itself been characterised by sharply divergent views on public involvement, distinguishing between participation to improve existing decisionmaking processes and legitimise government and a more radical approach that is deeply sceptical of the promise of stakeholder governance. ${ }^{104}$

Just as the environmental justice movement in the United States criticised existing environmental lobby groups for focusing on the interests of the elite, so it is important that the NGOs monitoring the implementation of cohesion 
funding also take into account the interests of the most environmentally disadvantaged within Europe. This should supplement campaigning for those interests that appeal to the more powerful, notably climate change and the protection of biological diversity after all, 'if you're only concerned with clean streams and whales, then that limited view smacks people of color in the face' ${ }^{105}$ Clearly, there is no need to distinguish needlessly between the two: both improve environmental quality. ${ }^{106}$ The outstanding and vital issue is how to interrelate such evaluations with socio-economic criteria such as 'quality of life' or a 'decent standard of living' so that, for example, enhancing biodiversity may be recognised as one means of fostering a positive sense of identity with a place, or that visions of that place in the future may flow from local knowledge and a desire to conserve. There is, in other words, the possibility of a meaningful type of territorial cohesion, alert to local conditions, and rooted in community. But clean technology, home insulation and fuel poverty, safe open spaces, access to clean water and waste and sewerage regulation are also key concerns of environmental justice as implemented through the principles of solidarity and territorial cohesion.

\subsection{Conclusion}

The evaluation of cohesion policy suggests that there are real substantive advances in the transposition and implementation of EU environmental law. ${ }^{107}$ The promotion of environmental justice is more difficult to measure but includes not only the advantages of greater economic development and growth, including equal opportunities to engage in entrepreneurial activity and to receive services, but also a concern for an equitable distribution of environmental protection and access to environmental services, pursued and made meaningful locally.

These new claims for environmental justice flow directly from the emerging EU territorial project. The narrative of territorial cohesion invokes the notion of EU territory and EU places, creating a new way of visualising the European Union, amplified by cohesion funding. This level of activity on matters spatial and territorial suggests a departure for the EU in terms of the development of concepts and policies and 'the acknowledgment and valorisation of knowledge on spatial issues'. ${ }^{108}$ But then, the entire EU project has always been defined by space and territory because its primary intent is to override boundaries, be they legal or physical impediments to the free movement of good, peoples, services and capital. From this perspective, the EU's spatial planning project, now presented as directed towards territorial cohesion, might be viewed not so much as an indicator of an organisation latterly seeking to impose a purposeful grip on the environment of its territory, but rather a reasonably successful attempt to co-ordinate (and repackage) its existing and persuasive, though admittedly indirect, influence over spatial matters and development, for example through structural funding 
decisions. Such a spatial approach overlaps with an understanding of environmental justice, at least within the EU, as being place-based and in situ rather than characterised as a claim for individual rights.

\section{Notes}

1 We would like to thank the participants at the Critical Environmental Law Seminar at Westminster Law School in June 2009 for their helpful and insightful comments on this project, which is where the chapter began. We would also like to thank Maria Adebowale at Capacity Global for her insightful and thoughtful contributions to the chapter.

2 For the concept of 'stuckness' and its relevance to law see Wightman and Jackson, 2002.

3 Directive 91/244/EEC (Habitats).

4 Directive 2000/60/EC (Water Framework).

5 Directive 2008/56/EC (Marine Strategy Framework).

6 Council Directive 91/676/EEC (Nitrates).

7 Council Directive 96/62/EC (Air Quality).

8 Commission of the EC (CEC), 2009a.

9 Commission of the EC (CEC), 2008b.

10 Commission of the EC (CEC), $2009 \mathrm{~b}$.

11 Commission of the EC (CEC), 2009c.

12 Holder and Layard, 2010.

13 Committee on Spatial Development (CSD), 1999; Commission of the EC (CEC), 2001: 24; Commission of the EC (CEC), 2008a; European Parliament, 2004.

14 Cremona, 2005.

15 Faludi, 2006: 673.

16 Lawton-Smith, 2003.

17 Commission of the EC (CEC), 2004a: 27.

18 Gualini, 2008; Philippopoulos-Mihalopoulos, 2010.

19 Scott, 1996.

20 Capacity Global, 2007; Friends of the Earth, 2001.

21 Callenbach, 1990.

22 Layard, 1999.

23 Rumford, 1999.

24 Commission of the EC (CEC), 2005: 24.

25 OECD, 2003.

26 Faludi, 2007: 568.

27 German Presidency, 2007; Commission of the EC (CEC), 2004a.

28 German Presidency, 2007: 2.

29 Davoudi, 2005: 433.

30 Commission of the EC (CEC), 1994.

31 Council of the EU, 2000a.

32 Council of the EU, 2000b: 4.

33 Alber, 2006: 394.

34 Sapir, 2006; Aiginger and Guger, 2006.

35 Jepsen and Serrano, 2005.

36 Jepsen and Serrano, 2005.

37 Commission of the EC (CEC), 2007; Nadin and Stead, 2008.

38 Gualini, 2008.

39 Faludi, 2007. 
40 Stichtung Greenpeace Council v EC Commission, [1998] 3 CMLR 1.

41 Convention on Access to Information, Public Participation in Decision-making and Access to Justice in Environmental Matters, Aarhus, 25 June 1998.

42 Harlow, 2006; McGillivray and Holder, 2001.

43 Howarth, 2009; Scott, 2000; Lange, 2006; Holder and Lee, 2007; Macrory and Turner, 2002.

44 Layard, 2009.

45 Layard, 2009.

46 Pellegrin, 2007: 210.

47 Weiler, 2002.

48 Ross, 2009.

49 Williams, 1999; Bullard, 1994a; Kurtz, 2003.

50 Bullard, 1996: 493; Bullard, 1994b.

51 Bullard, 1994a.

52 Bullard, 1994a; Agyeman and Evans, 2004.

53 Brulle and Pellow, 2006.

54 Williams, 1999; Bullard, 1994a; Kurtz, 2003; Been, 1993; Baden et al., 2007.

55 Capacity Global, 2007.

56 Beaumont and Nicholls, 2007; Jiménez, 2007.

57 Laurian, 2008: 55.

58 Health Protection Agency, 2005; Walker et al., 2005; Slater and Pedersen, 2009.

59 European Environment Agency (EEA), 2005: 7.

60 World Health Organisation (WHO), 2002, 2005.

61 Braubach, 2010.

62 Brulle and Pellow, 2006.

63 Capacity Global, 2007: The Black Manifesto, 2010.

64 Harper, et al., 2009: 262.

65 Foster, 1998: 779.

66 Bullard, 1994a.

67 Capček, 1993.

68 Schlossberg, 2004; Shrader-Frechette, 2002.

69 The Environmental Justice Project, 2003; DEFRA, 2008; Environmental Law Foundation, 2009.

70 Convention on Access to Information, Public Participation in Decision-making and Access to Justice in Environmental Matters, Aarhus, 25 June 1998.

71 Kuehn, 2000.

72 Cole, 1994; Mank, 2007.

73 (1994) 20 EHRR 277.

74 (2007) 45 EHRR 10.

75 Application No. 67021/01, unreported.

76 Bullard, 1994a.

77 Martuzzi et al., 2010: 24.

78 Agyeman and Bickerstaff, 2009: 797.

79 Towers, 2000.

80 Agyeman and Bickerstaff, 2009.

81 DG Regio, 2008.

82 Scott, 1996; European Environment Agency (EEA), 2009.

83 European Environment Agency, 2009: 96.

84 Jordan, 1999.

85 Mastenbroek, 2005.

86 Doucet, 2006: 1484.

87 Agyeman, 2002. 
88 Mutz et al., 2002; Natural England, 2009; CABE, 2009.

89 Kidd, 1999.

90 EEA, 2005.

91 Debbané and Keil, 2004: 209.

92 Agyeman and Evans, 2004.

93 Romm, 2002.

94 Burningham and Thrush, 2003.

95 Agyeman and Angus, 2003.

96 Layzer, 2002.

97 Knopman et al., 1999.

98 Mason, 2008.

99 Knopman et al., 1999.

100 Abel and Stephan, 2000.

101 Romm, 2002; Agyeman and Evans, 2004.

102 Layzer, 2002.

103 Morris, 2008.

104 Backstrand and Lovbrand, 2006.

105 Kidd, 1999.

106 Capacity Global, 2007, 2009a, b.

107 DG Regio, 2010.

108 Gualini, 2008: 7.

\section{Bibliography}

Abel, T. D. and Stephan, M. 'The limits of civic environmentalism' 44 (4) American Behavioral Scientist, 614-28, 2000.

Agyeman, J. 'Constructing environmental (in)justice: transatlantic tales' 11 (3) Environmental Politics, 31-53, 2002.

Agyeman, J. and Angus, B. 'The role of civic environmentalism in the pursuit of sustainable communities' 46 (3) Journal of Environmental Planning and Management, 345-63, 2003.

Agyeman, J. and Bickerstaff, K. 'Assembling justice spaces: the scalar politics of environmental justice in north-east England' 41 (4) Antipode, 781-806, 2009.

Agyeman, J. and Evans, B. "Just sustainability": the emerging discourse of environmental justice in Britain?' 170 (2) Geographical Journal, 155-64, 2004.

Aiginger, K. and Guger, A. 'The ability to adapt: why it differs between the Scandinavian and continental European models' 14 (1) Intereconomics, 14-23, 2006.

Alber, J. 'The European social model and the United States' 7 (3) European Union Politics, 393-419, 2006.

Backstrand, K. and Lovbrand, E. 'Planting trees to mitigate climate change: contested discourses of ecological modernization, Green governmentality and civic environmentalism' 6 (1) Global Environmental Politics, 50, 2006.

Baden, B., Noonan, D. and Turaga, R. 'Scales of justice: is there a geographic bias in environmental equity analysis?' 50 (2) Journal of Environmental Planning and Management, 163-85, 2007.

Beaumont, J. and Nicholls, W. 'Between relationality and territoriality: investigating the geographies of justice movements in the Netherlands and the United States' 39 Environment and Planning A, 2554-74, 2007.

Been, V. 'What's fairness got to do with it? Environmental justice and the siting of locally undesirable land uses' 78 Cornell L. Rev., 1001-85, 1993. 
Black Manifesto: The Price of Race Inequality, London: Race Equality Policy, 2010.

Braubach, M. et al. 'On the way to Parma: understanding and addressing the influence that social inequities have on environmental health' 20 (1) European Journal of Public Health, 12-13, 2010.

Brulle, R. and Pellow, D. 'Environmental justice: human health and environmental inequalities' 27 (3) Ann. Rev. Public Health, 1-22, 2006.

Bullard, R. 'Overcoming racism in environmental decision-making', 36 Environment, 10-44, 1994a.

Bullard, R. 'Environmental racism and invisible communities', 96 West Virginia Law Review, 1037-50, 1994b.

Bullard, R. 'Environmental justice: it's more than waste facility siting' 77 Social Science Quarterly, 493-99, 1996.

Burningham, K. and Thrush, D. 'Experiencing environmental inequality: the everyday concerns of disadvantaged groups' 18 (4) Housing Studies, 517-36, 2003.

CABE Grey to Green: How we switch Funding and Skills to green our Cities London: CABE, 2009.

Callenbach, E. Ecotopia New York: Bantam, 1990.

Capacity Global Environmental Justice and Race Equality in the European Union London: Capacity Global, 2007.

Capacity Global Hard to Reach London: Capacity Global, 2009a.

Capacity Global Every Action Counts: The Diversity Report London: Capacity Global, 2009b.

Capček, S. 'The environmental justice frame: a conceptual discussion and an application' 40 Soc. Probs, 5-24, 1993.

Cole, L. 'Environmental justice litigation: another stone in David's sling' 21 Fordham Urb. L.J., 523-45, 1994.

Commission of the EC (CEC) Social White Paper European Social Policy: A Way Forward for the Union. A White Paper COM (94) 333 final, 1994.

Commission of the EC (CEC) Unity, Solidarity, Diversity for Europe, its People and its Territory: Second Report on Economic and Social Cohesion COM (2001) 24, 2001.

Commission of the EC (CEC) Third Report on Economic and Social Cohesion: A New Partnership for Cohesion: Convergence, Competitiveness and Cooperation COM (2004) 107 final, 2004a.

Commission of the EC (CEC) White Paper on Services of General Interest COM (2004) 374 final, 2004b.

Commission of the EC (CEC) Communication to the Spring European Council: Working together for Growth and Jobs: A New Start for the Lisbon Strategy COM (2005) 24, 2005.

Commission of the EC (CEC) Fourth Report on Economic and Social Cohesion COM (2007) 273 final, 2007.

Commission of the EC (CEC) Fifth progress report on economic and social cohesion: Growing regions, growing Europe COM (2008) 371 final, 2008a.

Commission of the EC (CEC) Working for the Regions: EU Regional Policy, 2007-2013 Brussels: DG Regio, 2008b.

Commission of the EC (CEC) "Cohesion policy backs "green economy" for growth and long-term jobs in Europe’ IP/09/369, Brussels, 9 March 2009, 2009a.

Commission of the EC (CEC) Communication concerning the European Union Strategy for the Baltic Sea Region COM (2009) 248 final, 2009b. 
Commission of the EC (CEC) Sixth Progress Report on Economic and Social Cohesion COM (2009) 295 final, 2009c.

Commission of the EC (CEC) EU Strategy for the Danube Region, REGIO/E1/EN/ NV/OB D (2010) Brussels: DG Regio, 2010.

Committee on Spatial Development (CSD) European Spatial Development Perspective: Towards Balanced and Sustainable Development of the Territory of the European Union (ESDP), presented at the informal meeting of Ministers responsible for spatial planning of the Member States of the EU, Potsdam, 10-11 May 1999.

Council of the EU Presidency Conclusions, Lisbon, 7-9 December 2000a.

Council of the EU Presidency Conclusions: European Social Agenda, Nice, 7-9 December 2000b.

Cremona, M. 'EU enlargement: solidarity and conditionality' 30 E.L. Rev. 1, 3-22, 2005.

Davoudi, S. 'Understanding territorial cohesion' 20 (4) Planning, Practice and Research, 433-41, 2005.

Debbané, A-M. and Keil, R. 'Multiple disconnections: environmental justice and urban water in Canada and South Africa' 8 (2) Space and Polity, 209-25, 2004.

DEFRA Aarhus Convention Implementation Report London: Stationery Office, 2008.

DG Regio Annual Management Plan, Brussels: DG Regio, 2008.

DG Regio 'Ex-post evaluation of cohesion policy programmes 2000-2006 financed by the European Regional Development Fund in Objective 1 and 2 Regions: Synthesis Report', Brussels: DG Regio, 2010.

Doucet, P. 'Territorial cohesion of tomorrow: a path to cooperation or competition?' 14 (10) Eur. Planning Studies, 1473-85, 2006.

Environmental Justice Project Cost Barriers to Environmental Justice Report by the Environmental Justice Project London, 2003.

Environmental Law Foundation Cost Barriers to Environmental Justice London: Environmental Law Foundation, 2009.

European Environment Agency (EEA) Environment and Health EEA Report 10/2005 Copenhagen: EEA, 2005.

European Environment Agency (EEA) Europe's Environment: The Fourth Assessment Copenhagen: EEA, 2007.

European Environment Agency (EEA) Territorial Cohesion: Analysis of Environmental Aspects of the EU Cohesion Policy in Selected Countries EEA Technical report 10/2009 Copenhagen: EEA, 2009.

European Parliament Territorial Cohesion in Regional Development: European Parliament Resolution on the Role of Territorial Cohesion in Regional Development 2004/2256 (INI), 2004.

Faludi, A. 'The German role in the ESDP Process' 27 (4) Built Environment, 269-77, 2001.

Faludi, A. 'From European spatial development to territorial cohesion policy' 40 (6) Regional Studies, 667-78, 2006.

Faludi, A. 'Territorial cohesion policy and the European model of society' 15 (4) European Planning Studies, 567, 2007.

Foster, S. 'Justice from the ground up: distributive inequities, grassroots resistance, and the transformative politics of the environmental justice movement' $86 \mathrm{Cal}$. L. Rev., 775-841, 1998.

Friends of the Earth Environmental Justice: Rights and Means to a Healthy Environment for All London: Friends of the Earth, 2001. 
German Presidency 'Territorial Agenda of the European Union: Towards a More Competitive and Sustainable Europe of Diverse Regions', 2007.

Gualini, E. "“Territorial cohesion" as a category of agency: the missing dimension in the EU spatial policy debate' 28 European Journal of Spatial Development, 1-22, 2008.

Harlow, C. 'Civil society organisations and participatory administration: transforming EU administrative law?' in S. Smismans (ed.) Civil Society and Legitimate European Governance Cheltenham: Edward Elgar, 2006.

Harper, K. et al. 'Environmental justice and Roma communities in Central and Eastern Europe' 19 Environmental Policy and Governance, 251-68, 2009.

Health Protection Agency Health Protection in the Twenty-first Century:Understanding the Burden of Disease, Preparing for the Future London: Health Protection Agency, 2005.

Holder, J. 'Building spatial Europe: an environmental justice perspective' in J. Scott (ed.) Environmental Protection: EU Law and Governance Oxford: Oxford University Press, 2009.

Holder, J. and Layard, A. 'Relating territorial cohesion, solidarity and environmental justice' in M. Ross and Y. Borgmann-Prebil (eds) Promoting Solidarity in the European Union Oxford: Oxford University Press, 2010.

Holder, J. and Lee, M. Environmental Protection, Law and Policy Cambridge: Cambridge University Press, 2007.

Howarth, W. 'Aspirations and realities under the Water Framework Directive: proceduralisation, participation and practicalities' Journal of Environmental Law, 1, 2009.

Jepsen, M. and Serrano, P. 'The European social model: an exercise in deconstruction' 15 (3) Journal of European Social Policy, 231-45, 2005.

Jiménez, A. 'Is the urban acoustic pollution equitably distributed? An assessment of environmental justice in Madrid' 68 (263) Estudios geograficos, 595-626, 2007.

Jordan, A. 'The implementation of EU environmental policy: a policy problem without a political solution?' 17 Environment and Planning C: Government and Policy, 69-90, 1999.

Kidd, M. 'Environmental justice: a South African perspective' Acta Juridica, 142-60, 1999.

Knopman, D. et al. 'Civic environmentalism: tackling tough land-use problems with innovative governance' 41 (10) Environment, 24, 1999.

Kuehn, R. 'A taxonomy of environmental justice' 30 Environmental Law Reporter, 10681-703, 2000.

Kurtz, H. 'Scale frames and counter-scale frames: constructing the problem of environmental injustice' 22 Political Geography, 887-916, 2003.

Lange, B. 'Searching for the best available techniques: open and closed norms in the implementation of the EU Directive on Integrated Pollution Prevention and Control' 67 Int. J.L. Context 67, 2006.

Laurian, L. 'Environmental injustice in France' 51 (1) Journal of Environmental Planning and Management, 55-79, 2008.

Lawton-Smith, H. et al. 'European policy and the regions: an analysis and a review of tensions' 11 (3) European Planning Studies, 859-73, 2003.

Layard, A. 'Environmental justice: the American experience and its possible application to the United Kingdom' in J. Holder and D. McGillivray (eds) Locality and Identity Aldershot: Ashgate Press, 1999. 
Layard, A. 'Environmental Place-making in the EU: Evaluating the Spatial Application of Environmental Law', conference paper to Society of Legal Scholars, Keele, 2009.

Layzer, J. 'Citizen participation and government choice in local environmental controversies' 30 (2) Policy Studies Journal, 193-207, 2002.

Mank, B. 'Title VI and the Warren County protests' 1 Golden Gate U. Envtl L.J., 73-89, 2007.

Martuzzi, M. et al. 'Inequalities, inequities: environmental justice in waste management and health' 20 (1) European Journal of Public Health, 21-26, 2010.

Mason, R. Collaborative Land Use Management: The Quieter Revolution in Placebased Planning Lanham MD: Rowman \& Littlefield, 2008.

Mastenbroek, E. 'EU compliance: still a "black hole"?' 12 (6) Journal of European Public Policy, 1103-20, 2005.

Macrory, R. and Turner, S. 'Participatory rights, transboundary environmental governance and EC law' 39 Common Market Law Review, 489-522, 2002.

McGillivray, D. and Holder, J. 'Locating EC environmental law' 20 Yearbook of European Law, 139-71, 2001.

Morris, M. 'When it works and where it fails: spatial, temporal, and budgetary constraints to civic environmentalism' 89 (5) Social Science Quarterly, 1252, 2008.

Mutz, K. et al. (eds) Justice and Natural Resources: Concepts, Strategies, and Applications Washington DC: Island Press, 2002.

Nadin, V. and Stead, D. 'European spatial planning systems, social models and learning' 44 (1) disP: the Planning Review, 35-47, 2008.

Natural England, Inspiring People to Value and Conserve the Natural Environment: Draft Policy for External Consultation London: Natural England, 2009.

OECD, The Future of Rural Policy: From Sectoral to Place-based Policies in Rural Areas Paris: OECD, 2003.

Pellegrin, J. 'Regional innovation strategies in the EU or a regionalized EU innovation strategy? Conceptual and empirical underpinnings of the EU approach' 20 (3) Innovation: the European Journal of Social Science Research, 203-22, 2007.

Philippopoulos-Mihalopoulos, A. 'Spatial justice: law and the geography of withdrawal' 6 (3) International Journal of Law in Context, 2010.

Romm, J. 'Environmental justice in an era of devolved collaboration' in K. Mutz, C. Gary and S. Douglas (eds) Justice and Natural Resources: Concepts, Strategies, and Applications Washington DC: Island Press, 2002.

Ross, M. 'Healthy approach to services of general economic interest? The BUPA judgment of the Court of First Instance' 34 European Law Review, 127-40, 2009.

Rumford, C. European Cohesion? Contradictions in EU Integration London: Palgrave Macmillan, 1999.

Sapir, A. 'Globalization and the reform of European social models' 44 (2) Journal of Common Market Studies, 369-90, 2006.

Schlossberg, D. 'Reconceiving environmental justice: global movements and political theories' 13 (3) Environmental Politics, 517-40, 2004.

Scott, J. 'Environmental compatibility and the Community's structural funds: a legal analysis' 8 J. Environmental Law, 99-114, 1996.

Scott, J. 'Flexibility "proceduralization" and environmental governance in the EU' in J. Scott and G. De Burca (eds) Constitutional Change in the European Union Oxford: Hart Publishing, 2000. 
Shrader-Frechette, K. Environmental Justice: Creating Equality, Reclaiming Democracy New York: Oxford University Press, 2002.

Slater, A-M. and Pedersen, O. 'Environmental justice: lessons on definition and delivery from Scotland' 52 (6) Journal of Environmental Planning and Management, 797-812, 2009.

Towers, G. 'Applying the political geography of scale: grassroots strategies and environmental justice' 52 (1) Professional Geographer, 23-36, 2000.

Walker, G. et al. 'Industrial pollution and social deprivation: evidence and complexity in evaluating and responding to environmental inequality' 10 Local Environment, 361-77, 2005.

Weiler, J. 'A constitution for Europe? Some hard choices' 40 (4) Journal of Common Market Studies, 563-80, 2002.

Wightman, J. and Jackson, N. 'Spatial dimensions of private law' in J. Holder and C. Harrison (eds) Current Legal Issues, 2002: Law and Geography Oxford: Oxford University Press, 2002.

Williams, R. 'Environmental injustice in America and its politics of scale' 18 Political Geography, 49-73, 1999.

World Health Organisation (WHO) Children's Health and Environment: A Review of Evidence Copenhagen: WHO, 2002.

World Health Organisation (WHO) Children's Health and Environment: Developing Action Plans, Copenhagen: WHO, 2005.

\section{Legislation}

Council Directive 91/676/EEC of 12 December 1991 concerning the protection of waters against pollution caused by nitrates from agricultural sources [1991] OJ L $375 / 1$

Council Directive 96/62/EC on ambient air quality assessment and management OJ L $296 / 55$.

Directive 91/244/EEC on the conservation of natural habitats and of wild fauna and flora [1992] OJ L206/7.

Directive 2000/60/EC of the European Parliament and the Council establishing a framework for Community action in the field of water policy [2000] OJ L327/1.

Directive 2008/56/EC establishing a framework for Community action in the field of marine environmental policy (Marine Strategy Framework Directive) [2008] OJ L164/19. 


\title{
Heterotopias of the environment Law's forgotten spaces
}

\author{
Andreas Kotsakis
}

We do not live in a kind of void, inside of which we could place individuals and things.

M. Foucault

A spatial paradox dominates environmental law. As a discourse employing a host of geographical terms, such as territory and jurisdiction, and advocating the need for spatial transformation as an important component of the required change in individual and collective conduct, it nevertheless refuses to venture beyond the limited Cartesian spatiality of quantifiable, fixed on a map, empirical, 'absolute space'; in environmental discourse, the external landscape to social action, the precarious background to humanity's folly, the empty canvas to which environmental law gives shape.

At first instance, this spatial paradox may be easily attributed to an inherent positivism born from the descent of environmentalism from within the natural sciences and more specifically biology, as well as its later espousal of economic doctrines. At the same time, however, the paradox is equally a product of legal thought itself. The struggle for recognition of environmental law as a separate, autonomous legal field might have left a residue of disciplinary anxiety, which serves to accentuate the requisite 'assertion of legal closure' ${ }^{1}$ that all legal fields engage in. This closure appears as foundational for the creation of an autonomous, self-sufficient and clearly delineated legal 'territory' or domain, with its own internal logic, structure and principles that lift it above the fluctuations of politics and the uncertainties of social norms. For a legal field, such as environmental law, not only struggling to establish itself, but always straining to keep at bay the highly value-laden and politically charged social fields of environmentalism and political ecology, the adoption and staunch defence of legalistic characteristics, such as rational structure, formalism and objectivism, ${ }^{2}$ are conditions sine qua non for its constitution.

These characteristics enable environmental law to 'survive' by mapping out its legal domain, with an internal discursive structure to guarantee coherence, and by delineating strict boundaries that shelter it to a certain extent from 
political interests, value judgements and power struggles that take place within environmental discourse. This is especially the case when environmental law touches upon and ventures into highly politicised areas such as international aid and development, demography and population control. When environmental law is under siege, it falls back on its 'fort' of legal rationality and objectivity from which it also mounts 'attacks', aiming to prove law's practicality, social usefulness and necessity. The strong base of the legal domain allows for the rest of social space to be controlled and shaped by legal practices like an empty canvas.

\section{I The space of critical environmental law}

At the very moment of environmental law's extension into the field of international law, the limitations of the spatial paradox are exposed. Existing spatial arrangements are proving problematic and insufficient, especially since the transboundary aspect of most environmental problems equates success in environmental law with the achievement of global consensus and global impact on the environment. Thus, the effectiveness of environmental law largely depends on its globalisation, but this aim increasingly cannot be reached in the neo-liberal economic sense of exporting a single, universal model. A succession of counter-narratives have contested the globalisation of Western environmental ideas and constructions, ${ }^{3}$ arguing for more pluralist ethics and inclusive practices manifesting geographically as a heterogeneous multiplicity of social and cultural emplacements capable of being adapted according to contextual narratives of locality, identity and difference. ${ }^{4}$ The cartography of the legal domain, with its emphasis on coherence, isolation and fixed space and its association with 'Western metaphysics and its tribe of grids, binaries, hierarchies and oppositions, ${ }^{5}$ cannot accommodate this heterogeneous mosaic of differently scaled and marked maps, as persons and things resist being arranged according to a fixed Western topology.

This introduction is already filled with spatial metaphors, which further attest to the centrality of spatiality within legal thinking. Nevertheless, it is important not to confuse such counter-narratives that seek alternatives to Western modernity - by way of seeking alternatives to environmental government - with the simple attempt to finely balance the brutality of globalisation from above with the romanticism of localisation from below, a binary formulation already under examination, at least within socio-legal circles. ${ }^{6}$ From this narrower socio-legal studies perspective, the engagement with space is a geographical concern about how we can better understand law contextually and 'by reference to its place and relationship to economic, political, and ecological systems'. ${ }^{7}$

Instead, the critical legal project has often been connected with a search precisely for alternative articulations that do not ignore the heterogeneous spatiality of law. It does so by opposing itself to the perceived need for legal closure: 'the drawing of the conceptual boundary of law and the hoisting of 
the flag of legal theory over the terrain is not an innocent act' ${ }^{8}$ Once this project ventures into the field of environmental theory and political ecology, this articulating task for critical environmental law becomes even more complex: weaken the walls separating the legal domain, situate law in its geographical, historical and social context, while at the same time acknowledging the social and historical construction of nature. ${ }^{9}$ In many ways, the starting point of such a critique would be that environmental law has failed in its objective of raising itself above the ethical, political and cultural fray over nature and the environment. In addition, the spatial paradox of discussing geography while ignoring spatiality has exposed a 'double fault' in environmental law: not only does it consider nature as the 'inert background for the unfolding of the human saga', ${ }^{10}$ but it has also appointed itself as the sole cartographer of the background and arbiter of the lopsided saga. In other words, environmental law must open the gates of the meticulous fort it has built for itself and wander the sprawling streets, or slowly wither away inside.

Twenty-five years ago, Lyster discussed the danger of 'sleeping treaties' in International Wildlife Law. ${ }^{11}$ Ignoring the spatial turn in social theory today is tantamount to ignoring a host of narratives regarding the deficiencies and injustices of environmental law as an instrument for the arrangement of the socio-natural world according to Western modernity. This will result in a sleeping field, starving itself to death on account of its irrelevance. Therefore, instead of an analysis that focuses on constructing a coherent internal structure, indeed an analysis that is always 'self-conscious' and that seeks to rectify the inadequacy of the boundaries of environmental law as an autonomous legal field; instead of such an analysis, and in an attempt to construct a porous relationship between law and society, I propose here an analysis that allows and encourages environmental law to internalise dispersion, discontinuity and difference.

In this task set out for critical environmental law, the sometimes overlooked Foucauldian geography, and more specifically the concept of heterotopia with its spatiality of difference, can make a productive contribution. The following section discusses the concept of heterotopia, linking it with Foucault's work and clarifying some difficulties encountered in its application to the legal and environmental fields. The final section applies this heterotopology to three specific spaces that have, at times, enjoyed increased attention as the defining sites for the implementation of environmental law, namely the natural reserve of Western environmentalism, the local community of participatory development and the ethno-botanical institution encouraged within the biodiversity discourse.

\subsection{Finding heterotopias}

Understanding space as the product of constantly reformulating relations amongst sites, ${ }^{12}$ Foucault distinguishes both heterotopias and utopias as 
'sites ... that have the curious property of being in relation with all the other sites, but in such a way as to suspect, neutralise, or invert the set of relations that they happen to designate, mirror or reflect'. ${ }^{13}$ However, heterotopias are the dark underbelly of utopias. Utopias, 'sites with no real place, ${ }^{14}$ reflect, mirror, accentuate, designate and ultimately justify choices, preferences, laws and society itself in their ideal, perfected and flawless forms. They represent totality, completion, coherence, and in some ways efficacy and certainty of purpose. On the other hand, heterotopias are real, 'lived in' places that function as 'counter-sites, a kind of effectively enacted utopia in which ... other real sites ... are simultaneously represented, contested and inverted'. ${ }^{15}$ Armed with this peculiar spatial function, heterotopias expose and oppose, invert and divert, disassemble and upset legal and political choices by casting their preferred spaces in a different light. They represent dispersion, uncertainty, discontinuity, difference and, ultimately, impossibility. Foucault briefly examines a number of places that can qualify as heterotopias: parents' bed, garden tent, boarding school, rest home, psychiatric hospital, cemetery, theatre, museum, festival, and the heterotopia par excellence of the ship. 'Heterotopology' then becomes a general 'systematic description of these different spaces, of these other places', ${ }^{16}$ 'finding out where, how and for whom difference erupts and maintains itself' ${ }^{\prime}{ }^{17}$

The concept enjoyed only a brief surge of interest in the early $1990 \mathrm{~s}^{18}$ as part of a rather marginally successful postmodern programme in geography. Its resurrection, therefore, might initially appear a strange choice for constructing a critical enquiry into environmental law. The interest in locating and enacting heterotopias, especially by geographers and architects, is anchored in Foucault's often-quoted declaration: 'The present epoch will perhaps be above all the epoch of space. We are in the epoch of simultaneity: we are in the epoch of juxtaposition, the epoch of the near and far, of the side-by-side, of the dispersed. ${ }^{19}$ In the end, however, the application of heterotopia did not result in any appreciable or sustained body of research in geography. Two factors seem to affect this 'hesitant' development and patchy history of heterotopias within geography and social theory more generally. First, while widely considered a radical and insightful historian, ${ }^{20}$ Foucault's contributions to geography have received far less attention and only within a limited group of Anglo-Saxon geographers. ${ }^{21}$ Secondly, the concept itself enjoys a fairly unique and questionable status within Foucault's oeuvre, in that the text outlining the concept - essentially the notes for a lecture given in 1967 - was never reviewed for publication and was first seen at a Berlin exhibition in 1984. The interest in the concept arose after its English translation and eventual publication in Diacritics in 1986.

While heterotopias are merely one single tool in Foucault's famous 'toolbox', they cannot be viewed in isolation. It is important that one takes into consideration a number of different texts and sources, for otherwise, the tool might prove to be blunt and ineffective. ${ }^{22}$ There are in effect three variations 
of the concept of heterotopia in Foucault's work, along with some inevitable and crucial variations created by the English translations. The first brief mention of heterotopia can be found in the preface of The Order of Things, ${ }^{23}$ referring to discursive or textual spaces. The starting point of these particular discursive heterotopias is the disorder and the impossibility engineered by a strange classification of animals described by Borges. The second manifestation appeared towards the end of the same year (1966) in a radio broadcast, part of a series titled Utopie et littérature. ${ }^{24}$ Here Foucault first discusses the possibility of examining a range of different, other spaces created by society to counteract and subvert the dominant classifications. The starting point for these heterotopias that refer to actual social spaces is the temporal and spatial subversive effect created by a variety of children's games, through which different interpretations of everyday places and objects of 'adult society' are created. Finally, the third manifestation of heterotopia is also the better known and more widely employed in analyses. The lecture was given to a group of architects in 1967, eventually translated and published into English as 'Of other spaces' in $1986 .{ }^{25}$ This is the text that most analyses of heterotopia draw upon.

It has been suggested that Foucault was never fully satisfied with the analytics of space represented by heterotopology, and largely abandoned it in favour of the geography of knowledge/power presented through the Panopticon of Discipline and Punish. ${ }^{26}$ Evidence for this rejection is the fact that Foucault only agreed to the publication of the heterotopias lecture - without reworking it for publication - as accompanying text to an exhibition and only as late as 1984, seventeen years after the actual lecture and shortly before his death. ${ }^{27}$ However, to follow Foucault and abandon heterotopias would constitute essentially a rejection of Foucault's work, which he always understood as 'preparing a labyrinth into which I can venture ... opening up underground passages, forcing it to go far from itself, finding overhangs that reduce and deform its itinerary' ${ }^{28}$ For it is indeed the case that the attempt to construct a more complete picture of heterotopia as an analytical tool for critical environmental law can lead to the articulation of a subversive critique against established notions of legal implementation and its social effects.

\subsection{Impossible discourse and impossible spatiality}

At first instance, one could distinguish between the heterotopia of the preface in The Order of Things and the subsequent heterotopias lecture on the basis that the former refers to discursive heterotopias, while the latter refers to real places. But this distinction would not be precise enough. More careful examination supports the notion that the preface constructs the origins of heterotopology, which are then to complement the more specialist lecture. In that sense, the heterotopic origins lie at the intersection between discourse and space. 
The starting point is Borges's quotation of a Chinese taxonomy of animals (in itself a challenge to Western rationality) as well as the usual kind of animal knowledge that supports the project of environmental law:

Animals are divided into: (a) belonging to the emperor, (b) embalmed, (c) tame, (d) sucking pigs, (e) sirens, (f) fabulous, (g) stray dogs, (h) included in the present classification, (i) frenzied, (j) innumerable, (k) drawn with a very fine camelhair brush, (l) et cetera, (m) having just broken the water pitcher, (n) that from a long way off look like flies. ${ }^{29}$

For Foucault, the Chinese encyclopaedia becomes a symbol of sheer impossibility of perceiving and integrating such an 'absolutely other' system of thought. 'What is impossible is not the propinquity of the things listed, but the very site on which their propinquity would be possible. ${ }^{30}$ The juxtaposition of real and imaginary animals engenders a disorder 'in which fragments of a large number of possible orders glitter separately in the dimension, without law or geometry'. 31

This incommensurable system of classifying animals represents a primary example of a discursive heterotopia. This function, however, is possible only through its impossible spatiality, the simple observation that it is 'impossible to imagine a coherent space that would contain such a classificatory scheme' ${ }^{32}$ It is impossible to find a location common to all these fragmented and different 'orders', a topos that would hold all these proposed animal types and forms. If this paradoxical encyclopaedic listing constitutes a discursive heterotopia, it suggests that heterotopias can be different and 'other' spaces, lying outside the coherence that both discursive and spatial systems strive for. To take this interpretation further: a heterotopia challenges the discursive and spatial systems (such as law or geography) of Western modernity through its becoming 'a sort of compass [with which] to redraw maps and to rediscover the logic of those forms that remain hidden behind the tabular forms of modernity'. ${ }^{33}$

This heterotopic potential for redrawing the maps of modernity can be very productive in environmental law's task of engaging with its own multiple spatiality of difference, as set out in the opening section of this chapter. Being very close to Massey's proposition that 'we understand space as the sphere of the possibility of the existence of multiplicity in the sense of contemporaneous plurality, ${ }^{34}$ the examination of heterotopic spaces serves to bring forth the possibility that many different environmental constructions can and - more importantly - have already multiplied side by side within 'this sphere of coexisting heterogeneity'. ${ }^{35}$ In this sense, heterotopia constitutes a place contingent on difference; a place produced by social practices so as to illustrate a necessary contemporaneous heterogeneity. Environmental law has encountered its own particular 'Chinese encyclopaedia' in the politics of place and difference, the indigenous struggles for territory, the issue of 
environmental justice, the bio-piracy narrative and other categories of social action that the orthodox international environmental law of treaties, states and jurisdiction finds impossible to adequately incorporate. The effect of creating and accepting difference makes heterotopia a productive tool for engaging with the impossible spatiality of these concurrently 'place-based' and transnational discourses. Consequently, the identification of such environmental heterotopias can be seen to expose the spatial ignorance of environmental law; an ignorance that is anchored by the necessity of a coherent and value-neutral legal discourse as separate from the rest of social practices - and usher in a spatiality of coexisting difference that serves to end this legal isolation. The preface of The Order of Things illustrates that the displacing effect of these different spaces that can be identified as environmental heterotopias can arise from the dual impossibility of forcing the legal domain to hold too many contradictory elements (ecology and development, utilisation and stewardship, etc.), as well as of finding one single real place that can adequately represent this mixture. As the internationalist and globalist pressures of environmental law strip it off its spatiality to the point that legal closure becomes a hollow structure pursuing imaginary utopias, heterotopias remember the impact of environmental laws on the ground and the material practices that shape alternative environmental subjectivities.

\subsubsection{Subversion and counter-spaces}

Heterotopias are imperfect and deviating mirrors; they cannot function in the manner accomplished by utopias, embodying untroubled, and unreal, images; instead they expose memories of imposed orderings and subvert the language used to identify them. They are called 'effectively enacted utopias' ${ }^{36}$ or, alternatively, 'localised utopias', as in the 1966 radio broadcast. This primary subversive function is given more emphasis in that radio broadcast by Foucault, where he states that heterotopias are something 'that children know very well', going on to list a number of places where children's games take place: the garden, the attic, on or around the parents' bed etc. In this way, 'the children's inventive play produces a different space that at the same time mirrors what is around them. The space reflects and contests simultaneously. ${ }^{37}$ The covers of the bed are sheets made out of wool, but they can also represent the blue sky. The garden can be a dark forest in which to hide. The children's discourse produces a different space that is at the same time real and unreal, but usually fantastical, contesting the parents' more mundane reading and everyday use of the same space. The subversive fun lasts until the parents come home and restore logical coherence. With this example, heterotopias illustrate that other, different places are not only possible, but their unforeseen and subversive effects necessary - for the sanity of both parents and children.

In the lecture, this elementary example of heterotopia disappears and is replaced by the mirror, perhaps in some ways lessening the political and 
subversive heterotopic impact. This may be attributed to the fact that the mirror illustrates more clearly the confusion that heterotopia engenders. For heterotopia is a dual place (or object), encompassing two interconnected conceptions of space: the mirror itself - a real place inside reality; and the virtual space created on the outside of real space. Nevertheless, the example of the children's play implies the existence of certain agency in the setting of heterotopias, whereas the more oft-quoted lecture resorts from the outset to the obscure and difficult totality of 'society' as both the creator and the focus of the oppositional relation with heterotopia. This hypothesised societal whole that heterotopia is thought to contest, has been associated with the simplistic conception of fixed space that heterotopology seeks to overcome, leading to the characterisations of 'problematic geographical structuralism'38 or 'myopic sociological functionalism" 39 that underpin the criticisms of attempts to analyse the spatialisation posited by heterotopia.

This is especially pertinent to the application of the concept to environmental matters. What is the virtual whole that environmental heterotopias are neutralising, subverting, opposing? The example of the children's games can be used as a metaphor describing a principle of plurality or multiplicity that must characterise environmental law, but it also hides the danger of the paternalistic binary between 'parents' as the legal centre and 'children' as the social periphery of resistance (or even more detrimental and near-offensive the North as parents and the South as children) - precisely what the spatial turn seeks to avoid and a return to world arrangements according to the grids and hierarchies of modernity. Are these heterotopias simple indications of opposition to legal environmental discourses or to economic globalisation; are they indications of the fragmentation of international (environmental) law; a more complex challenge to the predominance of the Western modernity; sites for the formulation of alternative governmental rationalities through a resistance to their spatialising effects; or indeed all of the above? To further analyse the role of these 'counter-spaces', the analysis shifts to more concrete examples of places where the 'mapping' of environmental law has been concentrated.

\subsection{Enacting heterotopias}

The natural reserve is a symbol of the American invention of wilderness, of primal, 'untapped' nature with intrinsic, aesthetic and utilitarian values. The local community is the site of a tightly local group, possessing shared beliefs and value systems, emphasising the shift to participatory schemes of environmental government. The ethno-botanical institutions ${ }^{40}$ are spaces where the economic and cultural restoration of problematic Southern states and communities takes place. By placing people and things, by demarcating and dividing the sites of their everyday lives, by transforming the space of their collective social action, the environment will be healthy and wholesome 
again tomorrow. In this utopian promise, the environment is the fixed and homogeneous space of the neutral canvas and the Western map; a unified and quantifiable totality which environmental law attempts to arrange and govern.

Environmental heterotopias first and foremost disturb this utopian fixation of environmental legal practices. Heterotopias are social formations that counteract the abstraction of legal utopias that drives environmental discourse. They are located both outside and inside the global space assumed by environmental law. They contest both the legal practices that are supposed to emerge within legal discourse, as well as the spatialisation that these practices seek to disseminate. Eschewing the 'task' of the utopian embodiment of environmental ideals, heterotopias are places that both reflect and contest, subvert and alter environmental and legal narratives, ethics, aesthetics, or norms regarding the correct individual and collective conduct towards the environment. Viewed from this heterotopic perspective, both their formal 'appointment' as exemplary governable spaces and their discreet 'abandonment', once the narrative they supposedly embody falls out of favour, are events that point to historical shifts in the ways societies expect law to address environmental issues. Environmental heterotopias remember the forgotten spatialisations that did not function as planned, but are also real places illustrating this failure to their inhabitants and visitors on a daily basis. A failed place is harder to hide than a failed legal agreement. The establishment of such different trajectories can then become the compass for redrawing the grids and tables of modernity.

In order to enact fully this heterotopology, one first has to locate difference, dispersion and overall 'strangeness" ${ }^{41}$ of certain sites that exist both outside and within the society that environmental law is addressing. Foucault offers six observable traits that characterise heterotopias. These principles will assist in analysing the heterotopic functions of some common places of environmental discourse.

\subsection{Natural reserve: distanced crisis and ritual purification}

The setting aside of natural reserves, the 'walled-off' protected areas and the designation of official wildlife parks, widely considered a primary indicator of social awareness and concern over environmental issues, has already been a staple objective of environmental law. Early environmental discourse, from Rachel Carson's Silent Spring to UNESCO's World Heritage Convention, sought to transform the previously empty, value-neutral physical space into an aesthetically pleasing and thus intrinsically valuable landscape. This new landscape imposed a preservation mandate that was rooted in the aesthetic sensibilities of Western modernity. Once designated, these sites assume a privileged status, reserved for endangered nature, which is allowed to 'run wild' and reacquire its 'pristine' character within the borders of these areas. 
They constitute crisis heterotopias, ensuring that this rejuvenation 'takes place elsewhere', ${ }^{42}$ so as to not interfere with continued urban development and its by-products, such as pollution and overpopulation. By providing this 'guarantee' of an outside buffer space against complete degradation, the landscape of a protected area becomes a horizon that allows sustained development and continued urban living while maintaining a reserve to be used for future restoration.

This heterotopia reflects the simplistic character of the early spatialisation proposed by environmental law, which erects a barrier between the outside space of nature and the inside space of humanity. The environment was descending rapidly into a state of crisis due to destructive social practices, and the proposed solution was to lock it away, to prohibit interaction with the rest of society until that crisis state is surpassed. In a social context, similar places, according to Foucault, were the boarding schools (for girls) and military service (for boys). Any ecologist would be quick to point out that this isolation of the protected areas is no longer considered the best policy. This refers precisely to the first principle of heterotopology as outlined by Foucault: the replacement of crisis heterotopias by heterotopias of deviation, which alters the perception of the crisis, turning it instead into a problem of deviation from normal conduct. This is the case with the heterotopias of the local community and the botanical institution, which will be analysed below.

Another principle that can be observed in the function of the protected area is the link to slices in time or 'heterochronies' ${ }^{43}$ As an attempt to recapture the utopian wilderness aspect of nature, the heterotopia of the protected area is the de facto extension of the natural history museum and the botanical garden, the precedents of environmentalism in Western culture of the nineteenth century. The natural reserve is an attempt to manage 'a sort of perpetual and indefinite accumulation of time in an immobile place'. ${ }^{44}$ It appears as though environmental discourse suggests that there should be one space for natural history to unfold, and another, separate one, for human history to do the same.

Thirdly, 'heterotopias always presuppose a system of opening and closing that both isolates them and makes them penetrable ... the heterotopic site is not freely accessible like a public place'. ${ }^{45}$ Access here is not necessarily meant in the strict legal sense, but such a system does exist in all the spaces examined in this chapter. The protected area represents a dual, physical as well as conceptual, 'walling-off' of nature from humanity. To enter the natural reserve, one needs to have embraced specific ethics, to speak a certain truthful discourse: environmental scientists are allowed in the Alaska national park, but resource economists prospecting for oil are not so welcome. Agrotourists interested in organic produce or wine are welcomed in the Tuscan heartland around Florence, while tourists that require unsophisticated pleasures such as beer, bars and pools are frowned upon. The (post)colonial 
safari is alive and well around the Kenyan wildlife parks, while poaching bans are actively enforced. Such places cannot accommodate false and inappropriate discourses.

The spatial function of the protected area is similar to the example of the Muslim hamam cited by Foucault: 'one must have a certain permission and make certain gestures'. ${ }^{46}$ As the purification sought in a hamam is partly hygienic and partly religious, the ecological restoration occurring in the nature reserve is borne partly of necessity due to environmental crisis, and partly because of ethical reasons - the aesthetic value and beauty of nature as a counterpoint to the alienation of modern, urban life.

The primacy of such crisis heterotopias has been subsequently contested by the idea that preservation should be paired with the sustainable utilisation of natural resources, by the notion of sustainable development, as well as by the renewed focus on local and indigenous communities. These new principles transformed the contrived wilderness of the nature reserve into a much more crowded place - a different heterotopia signalling a different period in environmental history.

\subsubsection{Community: required deviation and the 'otherness' prison}

The increased prominence of the local and indigenous community due to legal instruments, such as the Biodiversity Convention and Agenda 21, is another spatial transformation engineered by environmental law in order to remove some of the limitations of the focus on protected areas. The wild and empty space of the protected area was no longer sufficient to arrest environmental catastrophe. The participation of adjacent communities, previously ignored or considered a contributor to environmental degradation, became an essential element of sustainable development, also giving rise to the stakeholder narrative. For the developing world, this localisation was linked to issues of empowerment and poverty reduction, through the recognition of land claims and the protection of traditional and indigenous lifestyles and their local knowledge. The new paradigm supported the notion that local populations were to be given incentives in order to protect the environment, to participate in environmental governance, instead of being forced to remain outside the borders of the protected areas. The primary incentive was economic: the promise of sustainable development.

According to this narrative, the local community is a site of inclusion into national society, into the market, into the global economic development, into environmental ideals of resource management. ${ }^{47}$ As well as a beneficiary of the social goods of sustainable development, it is also an owner and an 'author' of alternative, traditional or environmental, knowledge that should be integrated into the mainstream of techno-scientific environmental knowledge. There are certain spatial requirements for this 'idiom of inclusion'48 to be materialised. Within the context of fixed and absolute space, these localities 
generally have to be divided in small geographical units, with a homogeneous internal structure and shared social norms, ${ }^{49}$ small dots on the grand map. This is even more pronounced if the community happens to belong to a recognised indigenous group. For environmental law, the inclusion of these communities adds legitimacy to institutions and measures, incorporating ecological with social justice.

The perspective changes radically once these communities are viewed as heterotopias, as real places that carry the burden of implementing the privileged texts of environmental law. They are expected to perform the role of utopia, to become places that are stable, harmonious, long-lasting, the rural or indigenous character hiding wisdom and balance, defined in opposition to the modern dystopia of the urban, the developed, the West. Instead, they only reflect a nostalgic slice of time, a 'heterochrony' of difference and otherness that becomes a fixed image of how societies view them. Instead of the indefinite accumulation of time sought in the designation of the protected area, local communities are places where time has strangely stopped building up; they are refused the right to 'accumulate time', to evolve, to join other social groupings or networks. Rural populations have to maintain their authenticity and indigenous populations have to maintain their 'contrived ethnicity, ${ }^{50}$ constituting an ephemeral festival, a spatial and temporal prison with a very strict system of compulsory entry.

This can lead to bizarre and irrational outcomes, much alike the discontinuous and incongruous classification of the Chinese encyclopaedia. Writing on the US government-funded $\mathrm{ICBG}^{51}$ genetic research programme, Hayden finds a monolithic commitment, from the part of US National Institutes of Health (NIH) that run the programme to the territorialised local community as the bundled-together source of (semi-)raw material and destination for future benefits. ${ }^{52}$ Once the Mexico-based research programme decided to move away from this restricted conception of community (precisely because the utopian model of the clearly delineated community did not constitute an actual real location in Mexico due to the history between indigenous and Hispanic peoples) and adopt different ideas of plant sample collection from alternative sources, discontent arose at the NIH for 'breaking the link among people, plants and benefits'. ${ }^{53}$ These communities have to constitute observable and verifiable spatial units and beneficiaries of quantifiable social goods from sustainable development. When they expose and subvert the imposition of this fixed and external 'otherness', when they dislocate themselves from their supposed tight tribal structure and shared belief system, these communities end up neutralising the legitimacy sought by environmental law and its adoption of sustainable development. There is no colony to receive the teachings of the Christian missionary.

In direct contrast to the crisis aspect of the natural reserve, local and indigenous communities may thus be regarded as heterotopias of deviation, i.e. places 'in which individuals whose behaviour is deviant in relation to 
required mean or norm are placed'. ${ }^{54}$ This is a necessary deviation, to be attended to and studied, but never fully rectified, much like the situation in a prison or a rest home. Environmental law requires a sacrifice in order to grant inclusion into the legal domain, but the sacrifice ensures permanent exclusion. The meaning of the revalorisation of community in environmental discourse is quite clear: through the legal practice and process, we are going to protect you and include you, if you maintain your rural/indigenous character. You will no longer be on the outside. But once a community ceases to conform to the utopian ideal and fixed image imposed from above, no method of integration is available. By uncovering this process of marginalisation by inclusion (by way of a closely monitored system of entry), this environmental heterotopia illustrates the possibility of a place that is both inside and outside spatial and discursive orderings.

\subsubsection{Ethno-botanical institution: understanding environmental deviation}

The incompatible requirements of the empty protected area and the lived-in community are addressed in a third space, the ethno-botanical institution, much favoured in recent times and especially in biodiversity discourse. These institutions that have spread around the South are heterotopias 'capable of juxtaposing in a single real place several spaces that are in themselves incompatible', much like Foucault's example of the theatre as heterotopia. ${ }^{55}$ First, nature was to be left alone; then it had to be managed and protected by people in close proximity. Then, the aesthetics of the landscape had to be meshed with the rhetoric of sustainable development and ideas of social justice. One 'stage' where this hybridisation takes place is the ethno-botanical institution.

These institutions began being established in the South on the eve of the Biodiversity Convention's designation of biodiversity as a national resource and abandonment of the common heritage doctrine. ${ }^{56}$ Arguably their idea and set-up descend from the prototype that is the market-oriented private INBio of Costa Rica, a brainchild of American conservation biology ${ }^{57}$ and arguably the first of its kind. ${ }^{58}$ Such institutions, even under their more recent and successful guise as public agencies, are information nodes, acting as 'clearing houses' of knowledge, licences, contracts, policy and, ultimately, conduct towards the environment in order to bring into being locally informed sustainable development models. ${ }^{59}$ Their spatial role is that of a conduit: they gather and relate local and traditional environmental knowledge to global scientific discourse, while at the same time disseminating the tenets of global environmentalism to even more localities.

From the heterotopic perspective, these ethno-botanical institutions are relatively recent additions to the spatialisation effected by environmental law. The objective is precisely to merge together spaces that are considered 
incompatible. In contrast to the previous fixations with protected areas and local communities, these are instead 'active' sites, their hybridising spatial properties putting forward various projects of ecological, cultural and economic restoration, through the training of environmental behaviour. They do not constitute passive receptacles of the mandates of the privileged texts of environmental law agreed and passed elsewhere, but instead rely on the social construction of norms that contain elements of multiple sources and spaces; a multiplicity of 'people, plants and justice'. ${ }^{60}$

The crisis aspect of the protected area has been almost fully co-opted by the possibilities opened by these institutions, whose emergence in some ways complements the role of the local communities examined above. There is considerable overlap between the two spaces as regards the participation of the same persons and the arrangement of similar resources. In the case of the ethno-botanical institution, the point is made even more forcefully that their involvement in environmental government goes beyond reproducing or forcefully imposing binding standards and prohibitions. It embraces and seeks to 'understand' any deviation from the norms of environmental law and policy as set out by biology and economics, while the heterotopia of community simply sought to contain it in a fixed time and place. It forms part of a process of alternative and diversified making of environmental subjects in a Southern, decentralised setting of 'intimate government' ${ }^{61}$ While both constitute deviation heterotopias, the function of botanical institution appears similar to that of a psychiatric hospital - rather than the communal prison of contrived ethnicity. The romanticised but ultimately incomprehensible indigenous 'monster' existing outside the space and law of modernity is recast as an 'individual to be corrected', ${ }^{62}$ within a more conventional setting where 'deviant behaviours are established in the very moment of their analysis'. ${ }^{63}$ And these 'patients' are allowed to roam and formulate their own 'games' and interactions, assisted in their self-formulation as environmental subjects while simultaneously being 'trained' to participate in the normativity of a global society of markets and development.

In terms of taking into account multiplicity and heterogeneity (as outlined in the previous sections), there is little doubt that such institutions do represent a break in environmental law's spatial arrangements. In contrast to past environmental and developmental interventions, the botanical institution is not a remote centralising institution located in a distant country or a conference of the parties of an international treaty, but is located near the areas in the South that have been problematised especially by the concept of biodiversity. Thus, the overall legitimacy of a legal domain that can create and delegate authority to such institutions is ultimately raised, precisely because of this acknowledgement of spatial difference and engagement with local adaptation.

Nevertheless, this proximity raises the important and controversial issue of incentivising environmental protection through the promise of development, which relates to the 'system of opening and closing' of these heterotopias. 
The 'gates' of the botanical institution are presented as holding the promise of development; thus the power that is exercised by such institutions is increased by virtue of becoming a 'gateway' to a better life. The 'permissions and gestures' required to enter are eagerly performed by individuals and communities wanting to escape marginalisation and poverty. Irrespective of the gap between expectations and realities, 'the will to improve' 64 is a constant and 'stubborn' rationality for shaping environmental subjectivities and practices. But of course such an opening always 'hides curious exclusions': entering those sites is 'only an illusion: we think we enter where we are, by the very fact that we enter, excluded' ${ }^{65} \mathrm{~A}$ step forward in the recognition of the politics of place ${ }^{66}$ no doubt; but restrictions still exist. Botanical institutions secure the participation of stakeholders in conservation and development activities, not right holders or property owners, and of providers of raw material for a global industry of biotechnology ${ }^{67}$ Agreeing to 'enter' these botanical institutions is an acknowledgement of a poverty-stricken Southern identity and a submission to a constant analysis of that identity. On the other hand, these sites engender possibilities and pluralities in ways rejected by the processes of designating protected areas and of recognising local and indigenous communities, especially when viewed in isolation from each other. If these knowledge clearing houses are in fact fully fledged counter spaces at the heart of the legal domain, permitting 'acts of counterwork by locals', ${ }^{68}$ then the question (which cannot be answered here) becomes: are they producing alternative modernities (adaptations of Western modernity to Southern conditions) or alternatives to Western modernity itself ${ }^{69}$

\subsection{Conclusion}

This chapter has presented a heterotopic overview of the three spaces of the natural reserve, the local community and the botanical institution, all of which are much discussed in environmental law. The list of sites and objects that can be subjected to this form of spatial analysis is potentially large. Thus, one could also investigate the ephemeral festivals of self-congratulation that are the conferences of the parties; the transboundary but also local networks of farmers' associations and other similar movements; seed and gene banks; natural history museums; botanical gardens; those prized urban parks; farms (organic versus industrial); whaling ships and so on. While this chapter included a presentation of the theoretical framework, thus leaving little room for detailed analysis, the application of heterotopology arguably yields more insights if applied to specific places as opposed to spatial categories. ${ }^{70}$ Finally, it is obvious from the above that heterotopology is a method of analysis suited to the particular spatial turn required of environmental law. These caveats aside, the concept of heterotopia can produce a critique of the illusions and fixations of environmental law, in particular in its international manifestation. 
There is one last trait of heterotopias that has not been included in the above discussion of the three places. By maintaining an outside/inside spatial distinction the aim of all three heterotopias is to compensate for the environmentally problematic and already globalised product of development: the urban space of the modern city. From the perspective of modernity, the objective is always to construct a different space, 'as perfect, as meticulous, as well arranged as ours is messy, ill constructed, and jumbled'. ${ }^{71}$ When that utopian dream is suspended, one is left with the very real counter-space of heterotopia. Instead of the West's addressing its past failures through environmental law, it is for ever projecting them on to new localities, spaces and sites.

One of the starting points in 'Of other spaces' is the realisation that space itself has a history that cannot be disregarded. Environmentalism in general exhibits a profound dislike for historical arguments, especially if they relate to the history of environmental concepts and movements themselves. The impending ecological crisis calls for solutions, not introspection. This chapter contests this belief by showing, through the comparison between the different spatial uses of three places, that a historical examination of environmental ideas is also an important component of critical environmental law. This short and site-specific spatial history nevertheless uncovers the illusions of official policies, forgotten other places that subvert their utopian beginnings and remnants of failed law that no one wants to engage with. Instead of the impenetrable fort of law ruling over space, law becomes another part of a heterogeneous space 'in which we live, which draws us out of ourselves, in which the erosion of our lives, our time and our history occurs'. ${ }^{72}$

\section{Notes}

1 Blomley 1994: 7.

2 Blomley 1994: 9.

3 A small sample of such counter-arguments can be found in Guha 1989; Lohmann 1993; Sachs 1993; Guha and Martínez-Alier 1997; Escobar, Rocheleau et al. 2002; Martínez Alier 2002; Escobar 2004.

4 For some examples of these new formulations see Agrawal 2005 (India), Neumann 2002 (Africa), Li 2007 (Indonesia); for a more developed proposal of a 'placebased politics of difference' in relation to Latin America and derived from Colombian experience see Escobar 2008. In addition, these nominally anthropological studies are quite interesting from a methodological perspective, as they combine critical theory, regional and local ethnography and practical politics into a rich, transdisciplinary tapestry for examining environmental issues and conflicts.

5 Genocchio 1995: 35.

6 See Lee and Stokes 2009 and the rest of the special issue on globalisation and localisation of the Journal of Law and Society, 36 (1).

7 Holder and Harisson 2003: 3.

8 Blomley 1994: 11.

9 'Every generation writes its own description of the natural order, which generally reveals as much about human society and its changing concerns as it does about 
nature' (Worster 1994: 292). This 'inter-generational' historical aspect can be extended to the present 'intra-generational' social sphere. See Cronon 1995; Hannigan 1995. For a Foucauldian perspective, Darier 1999.

10 Escobar 2008: 29.

11 Lyster 1985.

12 Foucault 1986: 23.

13 Foucault 1986: 24.

14 Foucault 1986: 24.

15 Foucault 1986: 24.

16 Foucault 1986: 24.

17 Saldanha 2008: 2081.

18 The widest use of the concept of heterotopia can be found in the work of Edward Soja, see Soja 1989, 1995, 1996. For other applications, less tied to postmodernism, see Gregory 1994; Hetherington 1997; Hook and Vrdoljak 2002.

19 Foucault 1986: 22.

20 Veyne 1997.

21 For more on the notion of Foucault as a 'geographer' see Philo 1992, as well as Elden 2001; Crampton and Elden 2007.

22 This is the realisation of Peter Johnson's informative analysis of heterotopias, parts of which are adapted for this chapter. See Johnson 2006.

23 Foucault 2002b, original French publication 1966.

24 The radio broadcast from 1966 can be found online at: http://foucault.info/documents/heteroTopia/foucault.espacesAutres.fr.mp3.

25 Foucault 1967.

26 Philo 1992; Saldanha 2008.

27 Johnson 2006: 76.

28 Foucault 2002a: 19.

29 Foucault 2002b: xvi.

30 Foucault 2002b: xvii.

31 Foucault 2002b: xix.

32 Genocchio 1995: 40.

33 Bonazzi 2002: 43.

34 Massey 2005: 9.

35 Massey 2005: 9.

36 Foucault 1986: 24.

37 Johnson 2006: 76.

38 Saldanha 2008: 2084.

39 Genocchio 1995: 36.

40 This term is used here as generally descriptive of local and national institutions, organised in the South since the early 1990s, that seek to sustainably utilise biological and genetic resources themselves, as well as traditional and indigenous knowledge regarding their use and conservation, to achieve sustainable development and local empowerment through market participation, as defined in legal and policy documents, such as the Biodiversity Convention, Agenda 21 and the Bonn Guidelines on access to genetic resources and fair and equitable sharing of benefits arising out of their utilisation. The prototype was a private institution, the Instituto Nacional de Biodiversidad (INBio) of Costa Rica, with a somewhat limited remit regarding taxonomy and prospecting licences, but most Southern states now have designated public agencies, such as the Council for the Management of Genetic Patrimony (CGEN) of Brazil, for the management of these physical and knowledge resources in their entirety. For more information on their development and operation see McManis 2007. 
41 Genocchio 1995: 38.

42 Foucault 1986: 24.

43 Foucault 1986: 26.

44 Foucault 1986: 26.

45 Foucault 1986: 26.

46 Foucault 1986: 26.

47 Brosius, Lowenhaupt Tsing et al. 2005.

48 Hayden 2003.

49 Agrawal and Gibson 1999; Li 2005.

50 Wilder 1997.

51 The long-standing International Cooperative Biodiversity Groups Programme (http:// www.icbg.org/) was initiated in 1992 and represents a major US alternative proposal for biodiversity conservation and utilisation after the rejection of the Biodiversity Convention.

52 Hayden 2003: 362.

53 Hayden 2003: 366.

54 Foucault 1986: 25.

55 Foucault 1986: 25.

56 CBD, preamble and Article 3.

57 Through Daniel Janzen and Paul Ehrlich.

58 Takacs 1996: 288-308.

59 Gamez 2007.

60 Zerner 2000.

61 For a more detailed analysis of this process in relation to forest councils of Kumaon, India, see Agrawal 2005: 164-200.

62 This description of a progressive shift in perception borrows from the categorisation of individuals and definition of 'abnormality' found in Foucault 2000 and in more depth in Foucault 2003. This is prompted by Foucault's use of the term 'heterotopias of deviation', which points to his early to mid-1970s work on disciplinary power.

63 Foucault 1986: 25.

$64 \mathrm{Li} 2007$.

65 Foucault 1986: 26.

66 Defined as 'engagement with and experience of a particular location with some measure of groundness (however unstable), boundaries (however permeable), and connections to everyday life, even if its identity is constructed and never fixed' (Escobar 2008: 30).

67 For a critique of such arrangements see Shiva, Anderson et al. 1991; Delgado 2002; Coombe 2003; Hayden 2003.

68 Escobar 2008: 10.

69 This distinction is phrased in more detail in Escobar 2008: 156-99.

70 For examples see Heyd 1999; Hook and Vrdoljak, 2002.

71 Foucault 1986: 27.

72 Foucault, 1986: 23.

\section{Bibliography}

Agrawal, A., Environmentality: Technologies of Government and the Making of Subjects, Durham NC: Duke University Press, 2005.

Agrawal, A. and C. C. Gibson, 'Enchantment and disenchantment: the role of community in natural resource conservation', 27 World Development 4, 629-49, 1999. 
Blomley, N. K., Law, Space, and the Geographies of Power, New York and London: Guilford Press, 1994.

Bonazzi, A., 'Heterotopology and geography', 5 Space and Culture 1, 42-48, 2002.

Brosius, J. P., A. Lowenhaupt Tsing et al., eds, Communities and Conservation: Histories and Politics of Community-based Natural Resource Management, Walnut Creek CA: AltaMira Press, 2005.

Coombe, R. J., 'Works in progress: traditional knowledge, biological diversity and intellectual property in a neoliberal era', in Globalization under Construction: Governmentality, Law and Identity, ed. R. W. Perry and B. Maurer, Minneapolis MN: University of Minnesota Press, 2003.

Crampton, J. W. and S. Elden, Space, Knowledge and Power: Foucault and Geography, Aldershot and Burlington VT: Ashgate, 2007.

Cronon, W., ed., Uncommon Ground: Toward Reinventing Nature, New York: Norton, 1995.

Darier, E., Discourses of the Environment, Oxford: Blackwell, 1999.

Delgado, G. C., 'Biopiracy and intellectual property as the basis for biotechnological development: the case of Mexico', 16 International Journal of Politics, Culture and Society 2, 297-318, 2002.

Elden, S., Mapping the Present: Heidegger, Foucault and the Project for a Spatial History, London and New York: Continuum, 2001.

Escobar, A., 'Beyond the Third World: imperial globality, global coloniality and antiglobalization social movements', 25 Third World Quarterly 1, 207-30, 2004.

Escobar, A., Territories of Difference: Place, Movements, Life, Redes, Durham NC and London: Duke University Press, 2008.

Escobar, A., D. Rocheleau et al., 'Environmental social movements and the politics of space', 45 Development 1, 28-53, 2002.

Foucault, M., Des espaces autres : cercle d'études architecturales, Paris, 1967.

Foucault, M., 'Of other spaces', 16 Diacritics 1, 22-27, 1986.

Foucault, M., 'The abnormals', in Ethics: Essential Works of Foucault, 1954-1984, Vol. 1, ed. P. Rabinow, London: Penguin, 2000.

Foucault, M., The Archaeology of Knowledge, London: Routledge, 2002a.

Foucault, M., The Order of Things, London: Routledge, 2002b.

Foucault, M., Abnormal: Lectures at the Collège de France, 1974-1975, London and New York: Verso, 2003.

Gamez, R., 'The link between biodiversity and sustainable development: lessons from Inbio's bioprospecting programme in Costa Rica', in Biodiversity and the Law: Intellectual Property, Biotechnology and Traditional Knowledge, ed. C. R. McManis, London: Earthscan, 2007.

Genocchio, B., 'Discourse, discontinuity, difference: the question of "other" spaces', in Postmodern Cities and Spaces, ed. S. Watson and K. Gibson, Cambridge MA: Blackwell, 1995.

Gregory, D., Geographical Imaginations, Cambridge MA: Blackwell, 1994.

Guha, R., 'Radical American environmentalism and wilderness preservation: a Third World critique', 11 Environmental Ethics, 71-83, 1989.

Guha, R. and J. Martínez-Alier, Varieties of Environmentalism: Essays North and South, London: Earthscan, 1997.

Hannigan, J. A., Environmental Sociology: A Social Constructionist Perspective, London: Routledge, 1995. 
Hayden, C., 'From market to market: bioprospecting's idioms of inclusion', 30 American Ethnologist 3, 359-71, 2003.

Hetherington, K., The Badlands of Modernity: Heterotopia and Social Ordering, London and New York: Routledge, 1997.

Heyd, T., 'Art and Foucauldian heterotopias', in Discourses of the Environment, ed. E. Darier, Oxford: Blackwell, 1999.

Holder, J. and C. Harisson, eds, Law and Geography, Oxford: Oxford University Press, 2003.

Hook, D. and M. Vrdoljak, 'Gated communities, heterotopia and "rights" of privilege: a "heterotopology" of the South African security-park', 33 Geoforum, 195-219, 2002.

Johnson, P., 'Unravelling Foucault's "different spaces", 19 History of the Human Sciences 4, 75-90, 2006.

Lee, R. and E. Stokes, 'Environmental governance: reconnecting the global and the local', 36 Journal of Law and Society 1, 1-10, 2009.

Li, T., 'Engaging simplifications: community-based natural resource management, market processes, and state agendas in upland Southeast Asia', in Communities and Conservation: Histories and Politics of Community-based Natural Resource Management, ed. J. P. Brosius, A. Lowenhaupt Tsing and C. Zerner, Walnut Creek CA: AltaMira Press, 2005.

Li, T. M., The Will to Improve: Governmentality, Development and the Practice of Politics, Durham NC and London: Duke University Press, 2007.

Lohmann, L., 'Green orientalism', 23 Ecologist 6, 202-04, 1993.

Lyster, S., International Wildlife Law: An Analysis of International Treaties concerned with the Conservation of Wildlife, Cambridge: Grotius, 1985.

Martínez Alier, J., The Environmentalism of the Poor: A Study of Ecological Conflicts and Valuation, Cheltenham and Northampton MA: Edward Elgar, 2002.

Massey, D., For Space, London: Sage, 2005.

McManis, C. R., Biodiversity and the Law: Intellectual Property, Biotechnology and Traditional Knowledge, London: Earthscan, 2007.

Neumann, R. P., Imposing Wilderness: Struggles over Livelihood and Nature Preservation in Africa, Berkeley CA and Los Angeles: University of California Press, 2002.

Philo, C., 'Foucault's geography', 10 Environment and Planning D: Society and Space, 137-61, 1992.

Sachs, W., Global Ecology: A New Arena of Political Conflict, London: Zed Books, 1993.

Saldanha, A., 'Heterotopia and structuralism', 40 Environment and Planning A, 2080-96, 2008.

Shiva, V., P. Anderson et al., Biodiversity: Social and Ecological Perspectives, London: Zed Books, 1991.

Soja, E. W., Postmodern Geographies: The Reassertion of Space in Critical Social Theory, London: Verso, 1989.

Soja, E. W., 'Heterotopologies: a remembrance of other spaces in the citadel-la', in Postmodern Cities and Spaces, ed. S. Watson and K. Gibson, Oxford: Blackwell, 1995.

Soja, E. W., Thirdspace: Journeys to Los Angeles and other Real-and-Imagined Places, Oxford: Blackwell, 1996.

Takacs, D., The Idea of Biodiversity: Philosophies of Paradise, Baltimore MD and London: Johns Hopkins University Press, 1996.

Veyne, P., 'Foucault revolutionizes history', in Foucault and his Interlocutors, ed. A. I. Davidson, Chicago: University of Chicago Press, 1997. 
Wilder, L., 'Local futures? From denunciation to revalorization of the indigenous other', in Global Law without a State, Brunswick: Teubner, 1997.

Worster, D., Nature's Economy: A History of Ecological Ideas, Cambridge: Cambridge University Press, 1994.

Zerner, C., ed., People, Plants and Justice: The Politics of Nature Conservation, New York: Columbia University Press, 2000. 


\section{Majesty and monstrosity \\ Deleuze and the defence of Nature}

\section{Mark Halsey}

Through effective environmental and visitor management, Parks Victoria is dedicated to preserving the natural and heritage values of the parks, bays, and waterways, including full protection of sensitive areas. Preservation is our highest commitment. ${ }^{1}$

Parks remain the most taken for granted and unexamined regulatory forms in north American society. ${ }^{2}$

\section{I.I Introduction}

In his brief but quite brilliant essay 'Of other spaces' Michel Foucault focuses his attention on places which are 'unlike ordinary cultural spaces'. These heterotopic spaces, as he terms them, are simultaneously outside the state and yet fundamentally 'connected with all the sites of the city state or society'. ${ }^{3}$ In a similar way, and reflecting many of the principles of heterotopic spaces outlined by Foucault, I would argue that National Parks are 'unlike ordinary cultural spaces' and that they connect in complex and unconscious (or at least unspoken) ways to the spaces, persons and things around them. Indeed, drawing on Foucault's ${ }^{4}$ sixth principle of heterotopic spaces, I would argue that the National Park (as 'perfect', as 'meticulous', as 'well arranged' space) is produced directly by and in opposition to the city state (and, to invoke Foucault's terms, its corresponding 'messiness', 'ill construction', and 'jumbled' dimensions). It is a space, which, like the attempt to found a new colony, or to found a new religious order in distant lands, is constituted by the state as 'compensation' for and protection against the damage done to Nature in the initial forging of the city state.

In this chapter ${ }^{5}$ I explore the vicissitudes of this particular brand of compensation. Specifically, I pose and respond to the following three questions: (1) What conceptions of the 'social' and 'natural' are National Parks (and their variants) aligned to? (2) In what kind of "truth games" ${ }^{\prime}$ are particular discourses (law, science, conservation) implicated with regard to the invention and management of National Parks? (3) What can one rightfully claim to 
experience or bear witness to in such places? My intention is to respond to these questions through an examination of the (un)remarked significance of preserving and visiting National Parks, and, more particularly, significant trees. I argue that the prescribed beauty, rarity, or 'majesty' of such places or trees should in fact be read as a type of monstrosity. Throughout the chapter I will refer to two kinds of monstrosity: the monstrosity arising from treating Nature as endless copy (signalling the violence of representation) and the monstrosity born of the collision of two distinct chronologies - industrial time and geological time (signalling the violence of speed). The two, of course, intermingle and will be treated in such a manner. This idea of monstrosity as sign has been appropriately discussed by Torkild Thanem, who writes:

The words monster, monstrosity and monstrous all emerge from [the] Latin monstrum, which means portent, omen or sign, and from monere, which means warn. Moreover, they are related to monstrare, which means to show, demonstrate or prove ... [A] monster embodying unusual and irregular features was seen as punishment of past sins, prodigies (i.e. monsters found so horrible and fearsome that they would terrify humans) even announced greater punishment to come and not seldom the end of the world ... Monsters such as hermaphrodites were outside the course of Nature: prodigies such as a child born with a dog's tail were completely against Nature, results of abhorrent acts of bestiality ... Both were outside or contrary to Nature because of their heterogeneity, which disrupted the boundaries between beings that should be kept apart. $^{7}$

There are some (un)timely consistencies concerning the etymological/historical dimensions of monstrosity and what National Parks - more specifically, significant trees - can be taken to signify. In particular, these trees certainly appear on the physical and psychic landscape as remnants of 'past sins' (the result of colliding with Earth too intensely, at too great a speed, for too long) but equally, and counter-intuitively, they appear as 'outside or contrary to nature' in so far as they are remarkable exceptions to the general use and abuse of Earth. And, perhaps most critically, they permit a problematisation, as Thanem puts it, of 'the boundaries between beings that should be kept apart'. As monstrous beings - as heterogeneous bodies simultaneously the object of and manifestly beyond past and current industrial activity - such trees force us to think about the mixture of practices occurring in close and distant proximity to them.

Monstrosity should not be read as synonymous with the ugly, the inappropriate or the unbearable. Instead, I deploy the term in the Deleuzean sense of an encounter - of that which impacts the senses in ways not immediately amenable to pre-assigned or preconceived categories. A monstrosity is that 
which lingers in the space of the acategorical - that which refuses to be assigned (signed) a particular meaning or value and yet nonetheless is interpreted to be a sign of something, or some reckoning, or some critical moment. As Deleuze puts it:

Something in the world forces us to think. This something is an object not of recognition but of a fundamental encounter ... In whichever tone, its primary characteristic is that it can only be sensed ... [T] hat which can only be sensed ... moves the soul, 'perplexes' it - in other words forces it to pose a problem: as though the object of encounter, the sign, were the bearer of a problem - as though it were a problem ... [Encounters involve] an unlimited qualitative becoming ... [a] mad becoming. ${ }^{8}$

Art offers an appropriate way of thinking through the distinction between recognition and encounter. When first viewed by the public, Jackson Pollock's Blue Poles provided its audiences with, arguably, an encounter - its meaning was not evident in traditional ways of interpreting and talking about art. Very simply, it imploded the will toward representation and confounded the process of recognition. But in time Blue Poles moved from something acategorical (something which could only be sensed and not spoken of) to something categorical (something which should be interpreted and enunciated within the frame of modernism or abstract expressionism). Similarly, Mona Lisa - often described as the most famous artistic work of all time is, or has become, instantly recognisable. There is little, if any, capacity for an encounter with the image, its story and meanings having been told and retold countless times. The Mona Lisa is the image where the form and content of portraiture assume universal and seemingly timeless qualities. This is to be contrasted against Brett Whiteley's self-portrait, Art, Life and the Other Thing, which forces the viewer to undo the preconceived and well established versions of faciality $^{9}$ they carry with them. Deleuze and Guattari write:

concrete faces cannot be assumed to come ready-made. They are engendered by an abstract machine of faciality ... The head, even the human head, is not necessarily a face. The face is produced only when the head ceases to be a part of the body, when it ceases to be coded by the body, when it ceases to have a mulitdimensional, polyvocal corporeal code - when the body, head included, has been decoded and has to be overcoded by something we shall call the Face. ${ }^{10}$

The "face" in Whiteley's work is both Whiteley and not Whiteley. It is a portrait of self and other and something besides within the one frame. It is a becoming monstrous in the sense that it sounds a warning to those who dare to think portraiture in categorical terms (where it could, in any case, only 
implode under the weight of its lifeless repetitions). Whiteley's work - just like those of Picasso or Van Gogh - stands, in short, in opposition to the image of thought which would have us believe in the one face, the one identity, the one interpretation or 'judgement of the image'. ${ }^{11}$ Hence the primary questions which frame this chapter: What can one rightfully claim to experience in National Parks? or What kind of encounter is it possible to produce in National Parks or when making a pilgrimage to 'big' or 'ecologically significant' or 'historically significant' trees? What, more pointedly, is the problem to which such trees direct us toward or encourage a reckoning with?

\section{I.2 Law and the defence of Nature}

In order to respond to the aforementioned questions it is necessary to briefly explore what law (typically) does in its efforts to 'defend' Nature. That is, I think it important to make known the relationship between (Western) law and Nature generally before proceeding to ask how law envisages or codes aspects of the environment more specifically. The most obvious way in which law defends (protects) Nature is by regulation of human behaviour in particular domains (ticketing, signage, rules of conduct) and by the prosecution of bodies who contravene various regulations (instances of air, water and soil pollution, and so forth) in such areas. However, beyond these measures (beyond the command-and-control approach), I would argue that the primary means by which law attempts to secure good environmental outcomes is through the classification of terrestrial, aquatic and marine environments and the activities permitted therein. Law, in short, upholds particular regimes of value (environmental, economic, social, cultural, historical, etc.) which in turn afford various degrees of protection (World Heritage area, National Park, conservation park, special protection zone) to particular spaces. In effect, law demarcates the proper and improper use of Nature and is typically taken to occupy a space beyond the damage it is charged with negating.

In her classic work Purity and Danger Mary Douglas insightfully observed that 'where there is no differentiation there is no defilement'. ${ }^{12} \mathrm{I}$ take this to mean that the act of naming and dividing the Earth, whilst perhaps an inevitable event, is nonetheless one of immeasurable ethical weight, heralding not only many advantages but countless dangers as well. As Douglas puts it, '[T]he yearning for rigidity is in us all. It is part of our human condition to long for hard lines and clear concepts. When we have them we either face the fact that some realities elude them, or else blind ourselves to the inadequacy of the concepts. ${ }^{\prime 3}$ To ask law to do our bidding with regard to environmental protection (to ask law to be that 'hard line' between ecological integrity and ecological damage) is a hazardous enterprise for all kinds of reasons. For one thing, law tends to pay scant regard to the epistemologies and ontologies on which its demarcations are built. Nietzsche ${ }^{14}$ warned 
many decades prior to Douglas of the dangers adhering to a steadfast (reified) belief in the idols (binaries: National Park/industrial zone) we ourselves erect. Not just the idols of God, or Right, or Good or Evil, but equally and especially those of the sacred, taboo, species, individual, ecologically rare, ecologically common, high-risk, minimal-risk, wet forest, dry forest, eucalyptus regnans, eucalyptus nitens, and so forth. To quote Nietzsche,

All the knowledge which is of assistance to us involves the identification of things which are not the same, of things which are only similar. In other words, such knowledge is essentially illogical. ... The omitting of what is individual provides us with the concept, and with this our knowledge begins: in categorizing, in the establishment of classes. But the essence of things does not correspond to this: it is a process of knowledge which does not touch upon the essence of things $[\ldots]{ }^{15}$

The tendency for language to conflate what Deleuze ${ }^{16}$ terms 'individual difference' with the 'differences borne by individuals' is something I will return to later, since this is, to my mind, at the heart of the majesty/monstrosity debate. For the moment, let me simply venture that, for Deleuze, ${ }^{17}$ there can be no defence of nature, for Nature ${ }^{18}$ is that which has already been selected and coded - some might say, axiomised, by the socius. Nature is written and spoken (represented) in such a way as to sublimate what Deleuze terms the 'deep disparity' of the world. Nature (like justice, violence, democracy, sustainability) is an abstract machine marking out ahead of time what it is possible and not possible to say and do with respect to 'the environment'. To use one of Deleuze's ${ }^{19}$ phrases again, Nature is in the order of the image of thought - it is part of the plane of organisation where striated space (full of known bodies, known points and known risks) and royal science (as opposed to local/nomadic knowledges) predominate. For Deleuze, Nature is something conjured through the belief in the resemblance of species and terrains as well as the repetition of the discursive frames which present these species and terrains as having always already been there (lying in wait for science to 'discover', name and organise them and for law to give force to such discovering, naming and organisation). As Deleuze urges, 'Nature must be thought of as the principle of the diverse and its production. But a principle of the production of the diverse makes sense only if it does not assemble its own elements into a whole. ${ }^{20}$ For Deleuze, therefore, what needs 'defending', what needs engaging, is the plane of consistency (the acategorical) in all its complexity and vitality, and in its refusal to be pinned down by the categorical.

Law, to be clear, cannot defend Nature because 'nature' - in the primordial sense - is a flow of intensities and formations incapable of being assigned a definitive and proper place by any exterior force. Following the lead of Susan Chaplin, law positions itself as the force or line designed to keep chaos - in this case, the unpredictable or dangerous elements of 
Nature - at arm's length. As Chaplin remarks, '[L]aw exists only as th[e] "dividing line" that serves to exclude filth.' More important, 'filth exists not "in itself" but only with reference to "a boundary [ ... ] a margin" ... The law - the "inner and outer boundary" of this symbolic economy, the permeable margin between the sacred and the abject - is itself that which jeopardises the integrity of the community and its members. ${ }^{21}$ This clearly echoes Derrida's call to be consistently aware of the 'co-implication of violence and law'. ${ }^{22}$ This co-implication - the illusion of the neutrality and innocence of the line dividing filth from cleanliness, pollution from purity, violence from non-violence - goes to another of my key claims: that the partitioning or delimiting of the more 'majestic' aspects of Nature is to admit to the basically violent and intrusive character of interactions 'beyond' these places. The islands of wildness (or, more accurately, of (re)presented beauty) which law names and places to one side, are conceivable only on the basis of an ongoing and generalised ecological violence. National Parks are carved literally out of their antitheses (the non-park terrain). In short, why privilege and preserve particular places (forests, marine environments, deserts) if not for the fact that something fundamental and enduring threatens from without? But the issue goes much deeper than that. Specifically, I would argue that the 'force of capitalism' (the violence which founds and preserves the social and physical machinery of industrial society) is or has evolved to be a more trenchant force than the 'force of law' which portends, on occasion, to restrain it. ${ }^{23}$ There can be few better examples of this than in the curious relationship or juxtaposition of intensive industrial activity within or immediately abutting National Parks and/or World Heritage areas. Here, the "co-implication of violence and law" ${ }^{24}$ - law as 'the permeable margin between the sacred and the abject ${ }^{25}$ - is manifested in stark fashion.

\section{I.3 Law, industry, World Heritage}

Of the seventeen World Heritage areas in Australia, eleven appear on account of their exclusively natural values. At least three of these sites permit large-scale intensive industrial activity within or very near their borders (mostly in locations excised from actual World Heritage status). Shark Bay, located around $800 \mathrm{~km}$ north of Perth in Western Australia, and covering almost 22,000 km², 'is one of the few World Heritage properties inscribed for all four outstanding natural universal values: showing the earth's evolutionary history, ongoing ecological and biological processes, superlative natural phenomena, and important habitats for in situ conservation of biodiversity'. ${ }^{26}$ In spite of its outstanding ecological features, 'Mineral tenements (and applications for mining leases and exploration licenses) present within or adjacent to the World Heritage Property include those for gypsum, mineral sands, shell coquina (see section 4.3.19 Basic Raw Material Use) and salt (see section 4.3.18 Salt Production)'. ${ }^{27}$ In 2003-04 over 1 million tonnes 
of salt were produced at Useless Loop with an export value of around $\$ 17$ million. Coquina shell is also mined for use in footpaths, roads and concrete mix. Farming of sheep, goats and cattle on pastoral leases within the Heritage Area also occurs. ${ }^{28}$

A second example is provided by the Great Barrier Reef, which was declared 'a World Heritage Area in 1981, [having been] internationally recognised by the World Heritage Committee for its Outstanding Universal Value'. ${ }^{29}$ The World Heritage Area '[c]over[s] 344,000 [km²] and stretch[es] $2,300 \mathrm{~km}$ along the north-eastern Australian coastline. [I]t is the largest coral reef ecosystem [and largest World Heritage area] in the world'. ${ }^{30}$ The philosophy underpinning the management of the park is one of multiple use, ${ }^{31}$ with some activities arguably posing an ecological threat to the integrity of the area as a whole. One such activity is the high volume of oil tanker traffic permitted within the Great Barrier Reef Marine Park. The Marine Park Authority acknowledges that 'Since 1987 over 700 shipping or marine pollution incidents have been reported in the Great Barrier Reef Marine Park Authority's marine incident database. ${ }^{32}$ In fact, from 1987 to 2004 there have been 313 confirmed spills from vessels, 157 unconfirmed spills of origin and type, 84 instances of ships running aground on the reef, and 114 sinkings, including collisions and capsizings. ${ }^{33}$ In January 2006 the largest Great Barrier Reef oil spill in thirty-five years occurred as a result of a tugboat colliding with a ship in the port of Gladstone, releasing around 25 tonnes of oil into the park's waters.

A third and perhaps most controversial example of a World Heritage area being threatened by intensive industrial activity is Kakadu National Park, Northern Territory (first inscribed in 1981, with extensions of its boundaries occurring in 1987 and 1992). ${ }^{34}$ The area contains three extensive mineral leases devoted to the mining of uranium. Each of these leases 'were always enclaves, legally excluded from KNP [Kakadu National Park], although surrounded by it'. ${ }^{35}$ Ranger uranium mine is the most intensive of these and has featured prominently in public debate for three decades with ' $[\mathrm{t}]$ he first drum of uranium oxide ... produced on 13 August 1981'. ${ }^{36}$ This mine has expanded exponentially in size and production output since that date with, for instance, 'A total of 19.78 million tonnes of ore' mined in 1994 alone. There is no sign of activity abating, with mine operator Energy Resources Australia (ERA) announcing in October 2006 that 'Ranger mine's reserves' are sufficient to 'add[ ... ] six years to the predicted operational life' of the mine, meaning that it will be active until at least $2020 .{ }^{37}$ The Australian government, in typically bureaucratic and measured tone, has stated that 'The operation of a uranium mine and mill in a region which is World Heritage listed, subject to seasonal extremes in rainfall typical of monsoonal climates and which represents at least forty thousand years of habitation by the Aboriginal people, provides many environmental challenges'. ${ }^{38}$ 
There are, I would argue, at least two ways in which companies wishing to undertake major industrial activities within or near World Heritage areas work to neutralise opposition. The first involves making various claims regarding the scale of operations (the industrial footprint) in relation to the overall area of the heritage area in question. This explains the prominence in various reports of statements such as 'The Ranger mine is on a 7860 hectare lease which is surrounded by the World Heritage listed Kakadu National Park of 1.98 million hectares. About 500 hectares is actually disturbed by the mining and milling activities ( 0.025 per cent of the total area) $)^{\prime}{ }^{39}$ The concept or trope of vastness is of central importance to the logics of mining and its (possible) relationship to environmental damage. Vastness is called upon in order, inversely, to establish the smallness of the site in question. If something is small (industrially speaking) then it must be of far less urgent concern. Smallness of scale makes possible (and logical) the discourse of benign conduct. This in turn permits an arguably intrusive and ecologically damaging activity to be rewritten in terms of its insignificance. Ecological disturbance is, ironically, then discussed in terms of the impact to areas adjacent to or abutting the mine site (as if the originary ecological and cultural value of place and space taken up by the mine itself never existed). So '[a]bout 500 hectares is actually disturbed' but 1.98 million ha are not. The trope of vastness defuses the threat posed by the more traditional trope of synecdoche. The part (mine site) is made to bear no relation to the whole (World Heritage area). It does not stand for the whole, is not reducible to it, and cannot be considered as integral to the 'surrounding' area's ongoing integrity. This is in strict contrast to Nietzsche's aphorism that 'Nature is acquainted with neither shape nor size; only to the knower do things appear to be large or small'. ${ }^{40}$

The second manner by which opposition is neutralised, related to the first, is a more direct discussion of the risks (and their mitigation). Take the following statement: 'ERA has been recognised for its world-class environmental management, achieving ISO 14001 certification in $2003 \ldots$ No process or other contaminated water is released from the site. ${ }^{41}$ I mentioned earlier that law considers itself to occupy a space beyond the damage it is charged with negating. Related to this, law tries to ascribe ecology a safe place within which to reside. Law, in short, sets itself the task of ensuring that the monstrous and the majestic do not mix. Here, 'authentic' Nature, Nature at its 'best', need only be secreted away within law's domain in order to survive intact and in perpetuity. In one sense, this is how law procures its legitimacy in the arena of environmental protection. (Its great concession to industry, of course, is the sanctioning of the concept 'multiple use', which many times threatens the very values law initially is called on to preserve.) Mining companies also need to convince governments (and, to a lesser extent, the public) that their activities will not result in the monstrous mixture or intermingling of bodies. Toxic waste and ground water as well as 
radioactivity and human ill health are two 'couplets' which mining ventures try desperately to contain within separate universes. A mine in the middle of a World Heritage area - even if given the status of a 'legal enclave' - must present as an activity unto itself (as a closed circuit or loop with no deleterious effects beyond its borders). Indeed, it must treat its borders more in the manner of impermeable walls - as fail-safe barriers through which nothing passes except where intentionally permitted to do so by those operating the site. This, of course, is merely a desired state of affairs masquerading as an indisputable and eminently achievable scientific and industrial reality. As Ulrich Beck ${ }^{42}$ and others have shown, there is no such thing as zero risk or a closed loop in Nature (hence the importance of Deleuze's concept of flow). Only by thinking and writing the world as a knowable ensemble of causes and effects is a venture or monstrosity such as the World Heritage Ranger uranium mine possible.

Of course, in ecological terms, there is no such thing as a closed loop. Nature is composed of an infinite array of interrelational flows. The movement of debris from ships in the northern hemisphere to the currents of the southern hemisphere is stark evidence of this - as is the weather more generally (with, to name but one interaction, the ceaseless cycle of high and lowpressure systems generating so-called daily temperatures). World's best practice - 'achieving ISO 14001 certification' - does little to eliminate hazards and in fact ensures their presence within and beyond the operational period of particular projects. Three brief media extracts regarding recent problems at Ranger uranium mine illustrate this idea.

\section{Posted 6 March 2002}

A URANIUM leak at the Ranger Mine - which sent water contamination levels soaring to unprecedented levels - has prompted calls for a review of mine operator ERA. It was one of four breaches of the company's regulations since January, which included the first sign that contaminated water at the Jabiluka site could be tainting pristine water systems in the World Heritage-listed Kakadu National Park. Incorrect stockpiling of low-grade ore in a catchment area at Ranger is believed responsible for the contamination of Corridor Creek, which is within the lease and connects to the Magela River system used by Aborigines. According to tests taken by ERA early last month, but not reported to stakeholders until later in February, uranium levels in the creek reached almost 2000 parts per billion -4000 times the drinking water standard. ${ }^{43}$

\section{Posted 31 August 2004}

... The Ranger uranium mine in Australia's largest National Park was shut down today because of water contamination. In March, workers at Ranger drank and showered in water contaminated with uranium levels 400 times greater than the maximum Australian safety standard. 
Twenty-eight workers became ill as a result. ... The mine has a troubled history with 120 leaks, spills and operating breaches since it opened in $1981 .{ }^{44}$

\section{Posted 15 March 2009}

The Northern Territory Government says it will speak to mining company ERA and the office of the Commonwealth Supervising Scientist about contaminated water leaking from the Ranger Uranium Mine. About 100,000 litres of contaminated water is seeping from a tailings dam at the mine every day. Environmentalists are calling for the mine's planned expansion to be put on hold. The Office of the Supervising Scientist and ERA say the water is not seeping into Kakadu and there is no reason for concern. NT Resources Minister Kon Vatskalis says he is concerned, but the mine is well monitored. 'The Ranger Uranium Mine is one of the most strictly regulated uranium mines in Australia and the Office of the Supervising Scientist is controlling, is supervising, very strictly the mine,' he said. 'I'm prepared to talk with the Office of the Supervising Scientist to find out exactly what's happening, why it's happening and how the scientists and the company are going to address this issue,' he said. ${ }^{45}$

These events are plain (and tragic) manifestations of what Paul Virilio has termed 'the specific accident':

Every technology produces, provokes, programs a specific accident. For example: when they invented the railroad, what did they invent? An object that allowed you to go fast, which allowed you to progress - a vision à la Jules Verne, positivism, evolutionism. But at the same time they invented the railway catastrophe. The invention of the boat was the invention of shipwrecks. The invention of the steam engine and the locomotive was the invention of derailments. The invention of the highway was the invention of three hundred cars colliding in five minutes. The invention of the airplane was the invention of the plane crash. I believe that from now on, if we wish to continue with technology ... we must think about both the substance and the accident - substance being both the object and its accident. The negative side of technology and speed was censored. ${ }^{46}$

The invention of uranium mining is the invention of risks to public and ecological health. The specific accident is not incidental but fundamental to particular technological advances. It is always on the cusp of returning or being actualised. Safety itself implies the omnipresence - not the displacement of risk (and harm). Let me return momentarily to Douglas's cautionary remark that ' $[T]$ he yearning for rigidity is in us all. It is part of our human 
condition to long for hard lines and clear concepts. When we have them we either face the fact that some realities elude them, or else blind ourselves to the inadequacy of the concepts. ${ }^{47}$ If the juxtaposition of World Heritage areas and industrial activity within their boundaries demonstrates anything at all, it is that we have surely become blind to the wholly provisional and dangerous nature of the concepts used to govern activities in these areas. More than this, the type of monstrous couplings on display here - essentially, the coupling (or clash) of geological and industrial chronologies - shows that the interior of law, far from being a place to shelter from violence, is a place of turmoil and damage. In this sense, Chaplin is indeed right in her comment that "law - [as] the permeable margin between the sacred and the abject - is itself that which jeopardises the integrity of the community and its members'. ${ }^{48}$

To briefly recap, then, I have surveyed the way in which law threatens particular areas from 'within' - examining World Heritage areas whose values continue to be placed at risk by activities which geographically occur inside the borders of such spaces. It is of course necessary to acknowledge that various sites of industrial activity exist as legal enclaves in World Heritage areas (permitting them to be (re)presented as 'outside' the ambit of the World Heritage Convention). But, to my mind, location takes primacy over categorisation in such instances. Indeed, in one sense it is not about, for example, whether uranium mining occurs within or outside Kakadu National Park so much as about how the debate about uranium is continually conducted in relation to where it should occur rather than whether it should be permitted at all. I want now, though, to change the register of the analysis a little by focusing attention not on the meanings associated with the protection of large regions or ecosystems but on the protection of 'individual' organisms, namely big trees. This narrowing of focus will help to bring a new - if related - range of critical issues to the fore.

\section{I.4 Law and the majestic}

In this section I want to critically discuss the legal 'protection' extended to two particular 'majestic' trees located in different parts of Australia - the Ada Tree in Victoria, and El Grande in Tasmania. I use the term 'majestic' to connote the existence of a body or bodies which induce an ineluctable and chiefly unconscious reverence on account of their perceived beauty, rarity and location. The respective fates of the Ada Tree and El Grande are quite distinct, with the former still living and 'on display' in a dedicated reserve and the latter, although earmarked for protection by authorities, having been accidentally killed during a post-logging burning operation. Despite the fact that one of these trees still survives, there is, as I will suggest, little majesty and much monstrosity residing in both of these scenarios. Virilio is again relevant to this point and writes: 
[T] he dimension of the accident has changed, and we are faced with the emergence of an unprecedented accident. All technical objects brought about accidents that were specific, local and situated in time and space. The Titanic leaked in one place, while the train derailed in another. As for us, we have created the possibility of an accident that is no longer particular but general ... [T] here is an accident brewing that would occur everywhere at the same time: ... a global accident that would affect if not the entire planet, then at least the majority of people concerned by [ ... ] teletechnologies. ${ }^{49}$

National Parks and the protection of individual big trees can in many ways be viewed as a form of ecological insurance against the general accident of ecocide. They work on the basis that what is earmarked within their borders is simultaneously unique and representative of species and processes occurring beyond their boundaries. On this logic, the Ada Tree and El Grande - as 'single' organisms afforded legislated protection - stand (or were earmarked to stand) as insurance against the specific accident of the loss of forest giants (the loss of majestic remnants). The question is, how good is this insurance? More particularly, what risks does such a strategy (however appealing at first glance) carry with it?

A giant eucalyptus regnans, 'El Grande was located adjacent to the World Heritage Area in the Florentine Valley and was discovered [by volunteers] in June 2002 '. ${ }^{50}$ About 400 years old and $80 \mathrm{~m}$ in height, the tree was by no means the oldest or tallest in Australia, but according to the International Society of Arboriculture Australia Chapter (ISAAC), at around $400 \mathrm{~m}^{3}$ in weight, and with a girth of $18.75 \mathrm{~m}$, it was believed to be the largest in terms of volume. ${ }^{51}$ Under its 'Giant Trees Policy' (August 2002), Forestry Tasmania had an obligation to protect the tree from logging and all associated intensive activities (such as impacting of its root system from heavy machinery). ${ }^{52}$ El Grande was indeed placed on the list of giant trees but, shortly after a 'regulation' forest-burning exercise conducted by Forestry Tasmania in April 2003, the tree made world news for all the wrong reasons. On 5 June 2003 the UK Guardian asked, 'Is El Grande really dead?' On 10 December 2003 the BBC News (Asia Pacific Region) reported that 'Forestry officials admit killing biggest tree.' And, finally, on 7 March 2007 the Wilderness Society (Australia) reported, 'El Grande, Australia's most massive tree, topples.' It had, in short, been killed (literally 'cooked from the inside', to use the words of botanist Alan Gray) by a bureaucratically sanctioned fire that ultimately proved to be uncontrollable. ${ }^{53}$ Forestry Tasmania (in a statement dated 7 March 2007) put the following gloss on this series of events:

El Grande, the largest known eucalypt in Tasmania's forests, has unfortunately been blown over by the recent high winds coursing through the Derwent Valley. It had been noted many years ago that El Grande had a 
hollow core, which had weakened it structurally. Fortunately, the progeny of El Grande are growing near by from seeds Forestry Tasmania collected from El Grande during the harvesting process. These saplings are now three to four metres in height and are doing very well. These El Grande saplings will carry the 'giant tree' gene and, over time, grow to be forest giants. There are thousands of 'large' trees in Tasmania's State forests the tallest and largest of which are protected under Forestry Tasmania's Giant Trees Policy. People interested in Tasmanian giant trees can also consult the Giant trees register at www.gianttrees.com.au ... ${ }^{54}$

Excepting the reference to its 'hollow core' (which is typical of most healthy old-growth mountain ash trees), there is no mention here of why El Grande - after 400 years of vigorous growth - suddenly 'blew over'. The truth is that logging operations - the clear-felling of all trees around it for some substantial distance - exposed it to winds that it would have been sheltered from since the time of the Great Fire of London in 1666. The prescribed burn that finally destroyed the tree is standard practice in the forest industry in areas where eucalyptus regnans are logged. Very few if any trees could have survived the temperatures of such a fire. The press release issued by Forestry Tasmania speaks of what Deleuze calls the primacy of a 'field of individuation' (where individual trees are expendable because identical specimens can be found or permitted to take root) as opposed to the 'differences borne by the individual' ${ }^{55}$ (where each individual differs not on account of some internal uniqueness but on account of its irreducible - never to be repeated - place in the 'ocean of dissemblance'56). Deleuze writes, 'The highest generalities of life ... point beyond species and genus, but point beyond them in the direction of the individual and pre-individual singularities rather than towards an impersonal abstraction ... It is not the individual which is an illusion in relation to the genus of the species, but the species which is an illusion. ${ }^{57}$ On this count, the progeny of El Grande count for very little, since they are, in this instance, concomitant with the destruction of the singularity of unique animate and inanimate forces which composed the body of El Grande proper. The species may live on, but El Grande cannot be replaced - something which Forestry officials have never admitted. This is a monstrous course of events which resides as an omen to those interested in the fate of big trees. It shows that the individual organism cannot survive separate from a particular kind of milieu - that of old-growth eco-systems. Such a milieu cannot be artificed into existence or recreated within a politico-economic environment aligned to largely industrial chronologies. Forestry Tasmania, however, is attempting such artifice through its commitment to now ensure that 'groups of trees' are preserved around each individual tall and giant tree on its register.

In Victoria - the state due north of where El Grande once lived - a very different story of big tree conservation has unfolded. This story centres not 
so much around biological death as aesthetic decline and state-managed ruin of large tracts of forest. The Ada Tree is located in the Yarra State Forest of the Great Dividing Range about $80 \mathrm{~km}$ due east of Melbourne (the capital city of the state of Victoria, Australia). Like El Grande, the tree is an example of the eucalypt species known as mountain ash (eucalyptus regnans), renowned both for their size and, more recently, their rarity. They are the tallest flowering plant on earth and are generally accepted to have once grown taller than the redwood forests located on the west coast of the United States (specifically California and Oregon). Prior to its top being destroyed by wind or lightning, the Ada Tree was estimated to be around $120 \mathrm{~m}(400 \mathrm{ft})$ in height. At such a height it would have been the world's tallest known tree - exceeding the very recently discovered coast redwood (sequoia sempervirens) named Helparion estimated to be around $114 \mathrm{~m}$ or $380 \mathrm{ft}$ tall. ${ }^{58}$ Today the Ada Tree stands at a comparatively 'short' $76 \mathrm{~m}$ (253 ft) ${ }^{59}$ Unlike its counterparts in the United States (where redwoods are aged up to 3,000 years), the Ada Tree is thought to have germinated around 1727 - making it a 'mere' 280 years old. Still, at the time the Ada Tree was a seedling the 'discovery' of Australia by Captain James Cook would not occur for another sixty years. (Indigenous people had, however, lived in this land for some 40,000 years.) In a world replete with industrial intrusion it is somewhat astonishing that the Ada Tree remained secreted from public knowledge until 1986, when two brothers, prospecting for gems, stumbled upon it. ${ }^{60}$ With a girth of just over $15 \mathrm{~m}$ at breast height, and weighing more than 220 tonnes, the Ada Tree is, in mass terms, one of the largest trees and, by default, one of the largest living terrestrial organisms in Australia. ${ }^{61}$ In 1997 the Ada Tree was given legislated protection within the Ada Tall Trees Reserve. ${ }^{62}$

Counter-intuitive and heretical as it may sound, the Ada Tree is as much a monstrosity as a unique or remarkable specimen of eucalyptus regnans. By this I mean that reverence for the Ada Tree is born out of and inextricably tied to both the past and ongoing violence perpetrated upon eucalypt forests more generally. Just as Derrida ${ }^{63}$ has written that 'the parliaments live in forgetfulness of the violence from which they are born', in the same way do big trees stand in a displaced place - a place disconnected from the violence which, in fact, informs their 'majesty' and 'significance'. As the location of recent logging activity clearly shows, what is important about the Ada Tree is that the violence which preserves this organism is ongoing and proximate. There is, in short, an inverse and highly problematic relationship between the aesthetic, ecological and even 'spiritual' value ascribed to the Ada Tree, as against the rate and type of destruction occurring to the forests (ecological communities) in close and even distant proximity to it. It is in this sense that the fascination with the Ada Tree (indeed, with giant trees generally) stems from quite monstrous, even dangerous 'origins' and events. The Ada Tree is a body whose presence is made possible by the absence of countless other 
trees. To stand before the Ada Tree, then, is to witness something magnificent and abhorrent.

Like all designated conservation areas, the Ada Tree reserve is a manufactured space - a space where the striations and blockages are not so different from those confronted (or endured) in the city. In one of their most insightful passages Deleuze and Guattari write:

One of the fundamental tasks of the State is to striate the space over which it reigns, or to utilise smooth spaces as a means of communication in the service of striated space. It is a vital concern of every State not only to vanquish nomadism but to control migrations and, more generally, to establish a zone of rights over an entire 'exterior', over all of the flows traversing the ecumenon. If it can help it, the State does not dissociate itself from a process of capture of flows of all kinds, populations, commodities or commerce, money or capital, etc. There is still a need for fixed paths in well defined directions, which restrict speed, regulate circulation, relativise movement, and measure in detail the relative movements of subjects and objects. ${ }^{64}$

State law folds the smooth space of ecological processes into its generalised will to striation (or capture). It forces, in other words, the complexities of geological slownesses into the unidimensional frame of industrial speed. National Parks (conservation reserves and the like) are in this sense the remnants the state cedes in order to have greater control of the terrain beyond and abutting such areas. More than this, they are places made in the image of the state - places where the dimensions and uses are given by the state for the state. ${ }^{65}$ The logic of late capitalism - even and especially the capitalism devoted to ecological sustainability, ecological integrity and ecological diversity - produces, at best, a particular kind of ecological value. The state does all it can to subdue wildness, and, primarily, wildness is subdued by giving it a place, by ascribing it boundaries, by giving it dimensions. ${ }^{66}$ This is the sense in which the Ada Tree is a monstrosity. Or, perhaps, it is more accurate to say that the 'zone' in which the Ada Tree is permitted to stand is a monstrous space. As Deleuze and Guattari put it, 'the Smooth [i.e. smooth space] is both the object of a close vision par excellence and the element of a haptic space (which may be as much visual or auditory as tactile). The Striated [i.e. striated space], on the contrary, relates to a more distant vision, and a more optical space ... ${ }^{67}$ To my mind, this perfectly captures the logics of 'emparkment' and nature conservation generally. ${ }^{68}$ In short, the state cannot afford to look too closely at Nature. For to do so would require one to admit, as Deleuze so forcefully and beautifully argues, that life (earth) is characterised by a 'deep disparity' ${ }^{69}$ It would, in short, expose the unremarked violence of seeking to make one or a number of bodies stand for all such bodies. 
This last point goes directly to the heart of the matter. Whether the focus is on oil tankers in the Great Barrier Reef, uranium mining in Kakadu National Park, salt mining in Shark Bay World Heritage area, or on the conservation of particular trees or stands of forest, the central problem remains that of representation - which is, as Deleuze writes, 'a site of transcendental illusion' ${ }^{70}$ What holds the earth together - what permits it to press upon the senses, what permits encounters instead of recognitions - is difference (deep disparities), not resemblance. James Williams, commenting on Deleuze's work, cautions that 'difference is not a limit that stands as the origin or the end of a process of identification ... Rather, difference is that which turns all representations into illusions - identity is only a cloak thrown over deeper pure differences.' 71 Again, in Deleuze's words, 'the problem of classification was clearly always a problem of ordering differences. However, plant and animal classifications show that we can order differences only so long as we are provided with a multiple network of continuity of resemblance. ${ }^{72}$ Resemblance is the expression of the image of thought - of being ill prepared to negotiate the way forward in a world where, quite plainly, there can be no foundational or immutable division between the ecologically expendable and the ecologically unique, or between forest types (wet, dry, damp) and forest species (eucalyptus regnans, eucalyptus obliqua, eucalyptus nitens), or between this tree aged 300 years as against that tree of 150 years, or between this tree of $100 \mathrm{~m}$ in height as opposed to that tree of $90 \mathrm{~m}$ in height.

The division between National Park and state forest (or non-park) is, of course, a largely arbitrary one. But the division is nonetheless productive and what it produces is the idea of Nature as excess. This is a dangerous idea, for where Nature is in excess - where there is too much Nature - there seems little wrong with consuming its surplus. This surplus - this superabundance of Nature - enters the frame only on the basis that we portend to have mastered the art of representing and protecting species, and that we have struck upon the right formula for determining the minimal dimensions of the habitat needed for their survival. Whereas National Parks are often thought to be organised around the notion of rarity, they are in fact mostly conceived with regard to the politics of representativeness. This is why, for instance, intensive industrial activity is permitted to occur right up to and along the borders of such places. On this basis one can mine, cut and clear Nature in good conscience, because the boundary between park and nonpark is a scientifically valid one and anything mined, cut or cleared has its copy - its double - in the patchwork of parks and reserves established by the state. For Deleuze, this logic is based on a highly spurious notion of species and individual (and, specifically, the privileging of the former over the latter). More to the point, it takes things which are deeply disparate from one another and ascribes them the power to be the substitute or double of the other. Deleuze writes: 
We invoke a field of individuation or individuating difference as the condition of the organisation and determination of species. However, this field of individuation is posited only formally and in general: it seems to be 'the same' for a given species, and to vary in intensity from one species to another. It seems, therefore, to depend upon the species and the determination of species, and to refer us once more to differences borne by the individual, not to individual differences. In order for this difficulty to disappear, the individuating difference must not only be conceived within a field of individuation in general, but must itself be conceived as an individual difference. The form of the field must be necessarily and in itself filled with individual differences. ${ }^{73}$

It is this 'field of individuation' which makes the monstrous juxtaposition of industrial zones and conservation zones possible (of chainsaws or mining activity within earshot of a proscribed ecological rarity). Here, the state adheres to the belief that this field is indeed, as Deleuze says, identical for all species. It is this belief in turn that permits the violent and hazardous idea of Nature as endless copy (mimesis). Complete with its types and numbers of species, rates of reproduction and replenishment, thresholds of resilience and tipping points, the field of individuation sets in train the 'science' of representation. Where copies abound - where Nature as mimetic force is the order of the day - it no longer matters if a particular part of this field is 'lost' (to the workings of the chainsaw), for it can always be found. And the place in which late capitalism returns to find 'Nature' is in its 'representative' system of parks, reserves and gardens. With this field of individuation, the violence of carving out a place for wildness within discrete and ecologically significant units begins. 'The primary - and one might say, critical consequence of constructing a field of individuation (equivalent in many ways to the plane of organisation) is that it enables [the state] to classify the world according to the distribution and repetition of so-called like groups rather than, as would seem preferable, in terms of the differences borne by individuals.' $^{74}$

The Ada Tree, although still standing, and, for that matter, El Grande, although recently disappeared, are very much testimony to the ways in which various machines (political, legal, social, scientific) have recast the deep disparity of the world in terms of its similarities and resemblances (as constituted by phylum, genus, species, and so on). As an event, the Ada Tree speaks of the consequences of withdrawing from the close visioning of the world. Only by surveying from a distance (by shutting out the possibility of a "close-range" vision $^{\text {,75}}$ ) is one able to see similarities in, or, worse, copies of, this or that environment (bio-region, ecological vegetation class, forest type, etc.). The state - and its preoccupation with establishing an outside (chaos, wildness) and an inside (order, civilisation) - does all that it can to avoid the intermingling of the two. This is another way of saying that the state cannot afford to 
encounter singularities, or, more accurately, that, when it does, it must rewrite singularity in categorical terms - in ways recognisable to the bodies who venture to them, and thus in ways which attest to the careful and sustained displacement of a close visioning of Earth. It is not, therefore, a matter of revering or resenting the Ada Tree. It is not a matter of caring about or killing the Ada Tree or searching for another El Grande. It is a matter of killing representation - killing the divisions between nature and culture, between tree and forest, residing in our policies and laws - or, more pointedly, as Deleuze puts it, residing in our heads.

\section{I.5 Conclusion}

At the outset of this chapter I briefly made mention of Foucault's work on heterotopias. In concluding, I want to return to this concept and in particular to that of the library and museum as heterotopias of indefinitely accumulating time ${ }^{76}$ (see Figure 11.1). Recall that heterotopic sites are those which 'neutralise, or invert the set of relations that they happen to designate, mirror or reflect'. ${ }^{77}$ Foucault comments:

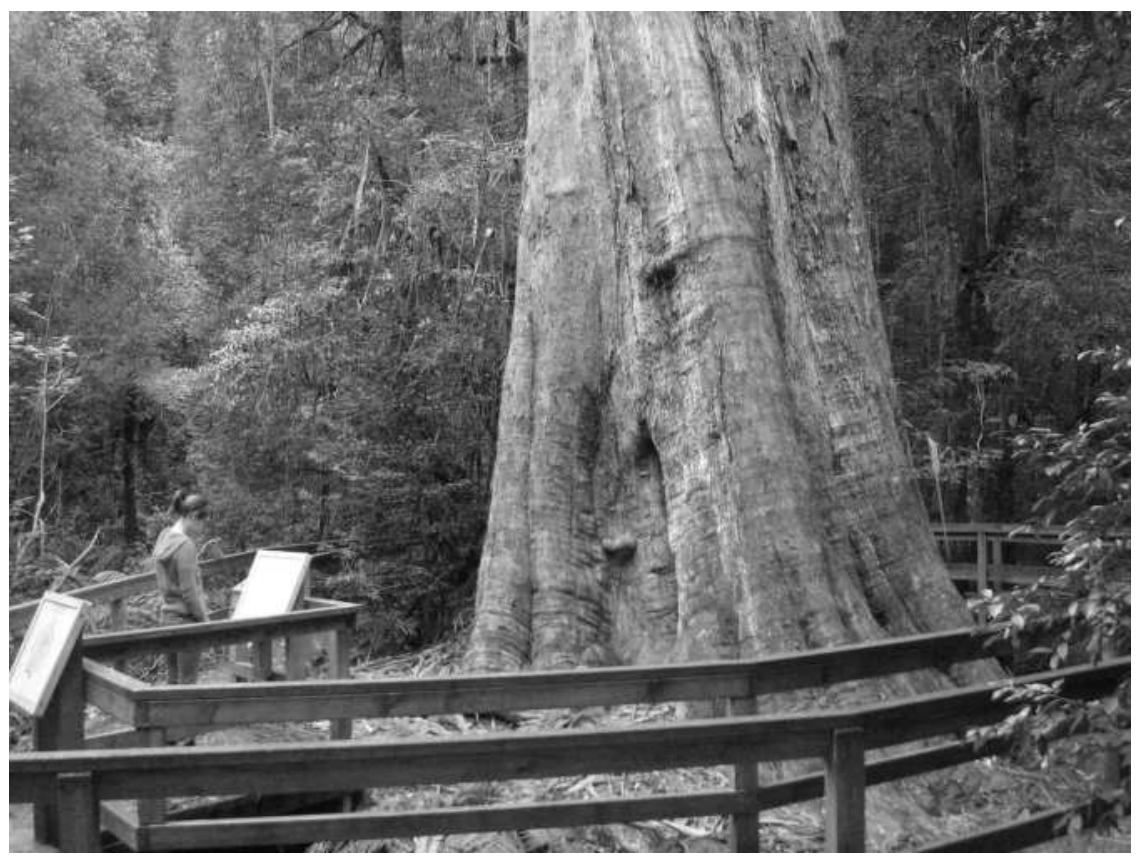

Figure 11.1 'Inside the museums, infinity goes up on trial', Bob Dylan, 'Visions of Johanna' (Blonde on Blonde, 1966). Witnessing the Ada Tree. Photo by Mark Halsey 
Museums and libraries have become heterotopias in which time never stops building up and topping its own summit ... [T]he idea of accumulating everything, of establishing a general sort of archive, the will to enclose in one place, all epochs, all forms, all tastes, the idea of constituting a place of all times that is itself outside of time and inaccessible to its ravages, the project of organising in this way a sort of perpetual and indefinite accumulation of time in an immobile place, this whole idea belongs to our modernity. ${ }^{78}$

Does this not speak at least in part of the function of seeking to represent Nature in National Parks? And does it not speak also to the penultimate impossibility of doing so? Climate change would seem to categorically demonstrate the futility of partitioning the planet into significant and insignificant places. To my mind, National Parks and tall or big trees should be made to function in the order of the 'great criminal' mentioned by Derrida in his essay 'Force of law'. As he writes, 'The admiring fascination exerted on the people by "the figure of the great criminal" ... can be explained as follows: it is not someone who has committed this or that crime for which one feels a secret admiration; it is someone who, in defying the law, lays bare the violence of the legal system, the juridical order itself' ${ }^{79}$ This is where National Parks and their variants serve to 'invert the set of relations that they happen to designate, mirror or reflect'. Each park, each reserve, each tree placed aside in museum-like conditions, are in a very real sense akin to deviant figures. The Ada Tree, just like the Centurion Tree in Tasmania, or Helparion in the United States, were not meant to survive. They should, by rights, be fence palings, roofing material or the structural support for some defunct gold mine. But they deviated from the norm. They survived by chance or because the technology of the time was not up to the task of felling them. As much as their presence goes to the majestic, however, they also stand as omens - a forewarning of the losses attending a particular mode of envisioning, consuming and regulating earth.

\section{Notes}

1 Parks Victoria, 'About Parks Victoria', http://www.parkweb.vic.gov.au/1aboutus. cfm, accessed 16 May 2009. The website continues, 'Parks Victoria is the custodian of a diverse estate of significant parks in Victoria and of the recreational management of Port Phillip Bay, Western Port and the Yarra and Maribyrnong rivers. Specifically the estate includes: forty national parks; thirteen marine national parks; eleven marine sanctuaries; three wilderness parks; twenty-seven state parks; thirty-one metropolitan parks; sixty-three other parks (including regional and reservoir parks); 2,785 natural features reserves and conservation reserves; 8,400 Aboriginal Affairs Victoria registered Indigenous cultural heritage sites/places; 2,500 (non-Indigenous) historic places. These assets total approximately 3.96 million ha (17 per cent of Victoria) - total area of parks and reserves.' 
2 Hermer, 2002: 113.

3 Foucault, 1986: 25.

4 Foucault, 1986: 27.

5 Sincere thanks to Andreas Philippopoulos-Mihalopoulos for commenting on a draft of this chapter. A small number of passages relating to discussion of the 'Ada Tree' have been reproduced and/or adapted, with permission, from Halsey, 2007.

6 Foucault, 1991: 51-75.

7 Thanem, 2006: 166-67.

8 Deleuze, 1994: 139-41.

9 Deleuze and Guattari, 1996: 167-91.

10 Deleuze and Guattari, 1996: 168 and 170.

11 Young, 2005.

12 Douglas, 2002: 198.

13 Douglas, 2002: 200.

14 Nietzsche, 2003.

15 Nietzsche, 1992: 51-52.

16 Deleuze, 1994: 251-52.

17 Deleuze, 1990: 261.

18 I use the term nature to signify the world as flow - as that which exists in a purely molecular fashion and which is not amenable to categorisation and organisation. I use the term Nature to denote the earth in its stratified form - the production of a so-called natural (and somehow non-human) world through discourse (science, law, popular culture, and so forth).

19 Deleuze, 1994: 129-67.

20 Deleuze, 1990: 266.

21 Chaplin, 2005: 165-66.

22 Derrida, 1992: 41.

23 Derrida, 1992.

24 Derrida, 1992: 41.

25 Chaplin, 2005: 165-66.

26 United Nations Monitoring Programme/World Conservation Monitoring Centre, 2008: 6. As at 2007, there were 162 sites on the World Heritage List on account of their exclusively natural values. Only eleven sites meet all four of the natural criteria given by the World Heritage Convention. Shark Bay resides in the company of such sites as the Galapagos Islands (Ecuador) and Yellowstone National Park (US).

27 Department of Environment and Conservation, 2008: 67.

28 Department of Environment and Conservation, 2008.

29 Great Barrier Reef Marine Park Authority (GBRMPA), http://www.gbrmpa.gov. au/corp_site/key_issues/conservation/world_heritage_faq, accessed 14 May 2009.

30 GBRMPA, http://www.gbrmpa.gov.au/corp_site/info_services/publications/brochures/ protecting_the_great_barrier_reef_marine_park, accessed 14 May 2009.

31 'The Australian Government's approach to all World Heritage areas has been one of allowing exploitative activities to continue ... as long as they do not threaten World Heritage values, are sustainable, are backed up by research and monitoring, and come under a planning and management umbrella ... In very large World Heritage areas like the Great Barrier Reef there really is no other option' (GBRMPA, http://www.gbrmpa.gov.au/corp_site/key_issues/conservation/world_heritage_faq, accessed 14 May 2009).

32 GBRMPA, http://www.gbrmpa.gov.au/corp_site/info_services/publications/sotr/ latest_updates/shipping/issues_pressures_and_threats, accessed 1 May 2009.

33 GBRMPA, http://www.amsa.gov.au/mmwip/e6a9b709e1534f53/bb623c0dbfc69aba. pdf, accessed 12 May 2010. 
34 Aplin, 2004.

35 Aplin, 2004: 156.

36 Energy Resources of Australia (ERA) Ltd., http://www.energyres.com.au/about_era/ history/ranger, accessed 14 May 2009.

37 ERA Ltd, http://www.energyres.com.au/about_era/history/ranger, accessed 14 May 2009.

38 Department of the Environment, Water, Heritage and the Arts (http://www.environment.gov.au/ssd/supervision/arr-mines/ranger.html, accessed 14 May 2009). The following gives some idea of the process involved in extracting uranium at Ranger. 'The ore is crushed to a fine powder and pumped as a slurry to a thickener to remove excess water, then to leach tanks where sulphuric acid is added. The acid dissolves the uranium and other minerals forming a uranium rich solution. After the solids have been removed, kerosene is used to selectively strip the uranium from the solution. Ammonia is then added to the strip solution precipitating the uranium in the form of ammonium diuranate which is passed to a furnace (called a calciner). In the calciner, the ammonia is driven off and the uranium is converted to uranium oxide concentrate, which is predominantly $\mathrm{U}_{3} \mathrm{O}_{8}$. The concentrate, which is a dark green to grey powder, is packed into 2051 drums for shipment and export.' (http://www. environment.gov.au/ssd/supervision/arr-mines/index.html, accessed 14 May 2009).

39 Australian Uranium Association (AUA), 'Uranium in Australia', http://aua.org. au/page.php?pid=341, accessed 1 May 2009.

40 Nietzsche, 1992: 43.

41 AUA, 'Uranium in Australia', http://aua.org.au/page.php?pid=341, accessed 1 May 2009.

42 Beck, 1992.

43 'Uranium leak near Kakadu', Australian, http://www.minesandcommunities.org/ article.php?a=928, accessed 1 May 2009.

44 'Uranium mine in Australian National Park closed for contamination', Environmental News Service, http://www.minesandcommunities.org/article.php?a=4677, accessed 1 May 2009.

45 'Uranium mine water leak concerning, gov[ernmen]t says,' Australian Broadcasting Corporation (ABC) News, http://www.abc.net.au/news/stories/2009/03/15/ 2516584.htm, accessed 24 June 2010.

46 Virilio, 1997: 37-38.

47 Douglas, 2002: 200.

48 Chaplin, 2005: 165-66.

49 Virilio, 1999: 91-93.

50 'El Grande, Australia's most massive tree, topples', Wilderness Society, http:// www.wilderness.org.au/articles/elgrande_4, accessed 28 November 2009.

51 ISAAC, 'Australia's biggest, tallest and oldest trees', http://isaac.org.au/info/bigtrees.htm, accessed 28 November 2009.

52 'Forestry Tasmania will seek to identify, manage and protect giant trees on State forest in Tasmania. Giant Trees are defined as trees that are at least $85 \mathrm{~m}$ tall or at least $280 \mathrm{~m}^{3}$ estimated stem volume. Based on current known examples, trees of this volume are generally at least $5 \mathrm{~m}$ in diameter at chest height' (Forestry Tasmania, 2002, http://www.forestrytas.com.au/uploads/File/pdf/giant_trees_policy. pdf, accessed 24 June 2010).

53 Guardian, 1 June 2003, http://www.guardian.co.uk/world/2003/jun/01/australia. theobserver1, accessed 12 May 2010.

54 Forestry Tasmania, 'El Grande', http://www.forestrytas.com.au/news/2007/03/elgrande-7th-march-2007, accessed 29 April 2009.

55 Deleuze, 1994: 251-52. 
56 Deleuze, 1994: 262.

57 Deleuze, 1994: 249-50.

58 The world's tallest known tree, Helparion, was located on 25 August 2006 in Redwood National Park, California, by, appropriately, Michael Taylor, dedicated bushwalker and tall tree adventurer (Preston, 2007: 282).

59 This height can be contrasted against that believed to be the tallest living mountain ash located in Tasmania. Known as the Centurion Tree, it has been measured at $101 \mathrm{~m}$ (320 ft) and was 'discovered' only in October 2008 by Forestry Tasmania staff whilst perusing tree stand data. The tallest mountain ash in Victoria is believed to be a tree known as Amabilis $(91 \mathrm{~m}$, or $298 \mathrm{ft}$ tall) located about $70 \mathrm{~km}$ north east of Melbourne on the Hume plateau (Preston, 2007: 265).

60 Griffiths, 2001: 22.

61 There are, as mentioned, taller trees both on the Australian mainland and in the island state of Tasmania. However, the Ada Tree exceeds the very tallest trees in terms of weight and girth.

62 The size of this reserve is a mere 14.5 ha and essentially provides a buffer zone of $50 \mathrm{~m}$ either side of Island Creek (which the walking trail to the Ada Tree follows). Additional 'protection' is provided around the Ada Tree itself to a $100 \mathrm{~m}$ radius. For a map of the dimensions see the schedule attached to National Parks (Amendment) Act 1997, Act No. 7/1997.

63 Derrida, 1992: 47.

64 Deleuze and Guattari, 1996: 385-86.

65 'States are made up not only of people but also of wood, fields, gardens, animals and commodities' (Deleuze and Guattari, 1987: 385).

66 See Hermer, 2002.

67 Deleuze and Guattari, 1996: 493.

68 Hermer, 2002: 3-24.

69 Deleuze, 1990: 261.

70 Deleuze, 1994: 265.

71 Williams, 2003: 56.

72 Deleuze, 1994: 247.

73 Deleuze, 1994: 251-52.

74 Halsey, 2006: 238.

75 Deleuze and Guattari, 1996: 492.

76 Foucault, 1986: 26.

77 Foucault, 1986: 24.

78 Foucault, 1986: 26.

79 Derrida, 1992: 33.

\section{Bibliography}

Aplin, G., 'Kakadu National Park World Heritage Area: deconstructing the debate, 1997-2003', 42 Australian Geographical Studies 2, 152-74, 2004.

Beck, U., Risk Society, London: Sage, 1992.

Chaplin, S., 'Fictions of origin: law, abjection, difference', 16 Law and Critique, 161-80, 2005.

Deleuze, G., The Logic of Sense, New York: Columbia University Press, 1990.

Deleuze, G., Difference and Repetition, New York: Columbia University Press, 1994.

Deleuze, G. and Guattari, F., A Thousand Plateaus, Minneapolis MN: University of Minnesota Press, 1996 (originally published in 1987). 
Department of Environment and Conservation, Shark Bay World Heritage Property Strategic Plan, 2008-20, Perth WA: Department of Environment and Conservation, 2008.

Derrida, J., 'Force of law: the "mystical" foundation of authority', in Carlson, D., Cornell, D. and Rosenfeld, M. (eds), Deconstruction and the Possibility of Justice, New York: Routledge, 1992.

Douglas, M., Purity and Danger: An Analysis of the Concept of Pollution and Taboo, London: Routledge, 2002.

Foucault, M., 'Of other spaces', 16 Diacritics 1, 22-27, 1986.

Foucault, M., 'Truth and power', in Rabinow, P. (ed.), The Foucault Reader, London: Penguin, 1991.

Griffiths, T., Forests of Ash: An Environmental History, New York: Cambridge University Press, 2001.

Halsey, M., Deleuze and Environmental Damage, London: Ashgate, 2006.

Halsey, M., 'Deleuze/Guattari and the Ada Tree', 15 Rhizomes, 2007, at http://www. rhizomes.net/issue15/halsey/index.html.

Hermer, J., Regulating Eden: The Nature of Order in North American Parks, Toronto: University of Toronto Press, 2002.

Nietzsche, F., Twilight of the Idols, London: Penguin, 2003.

Nietzsche, F., Philosophy and Truth: Selections from Nietzsche's Notebooks of the Early 1870's, ed. and trans. Daniel Breazeale, Totowa NJ: Humanities Press, 1992.

Preston, R., The Wild Trees, New York: Penguin, 2007.

Thanem, T., 'Living on the edge: toward a monstrous organization theory', 13 Organization 2, 163-93, 2006.

United Nations Monitoring Programme/World Conservation Monitoring Centre, 'World Heritage Site/Protected Areas and World Heritage: Shark Bay, Western Australia', March 2008, at http://www.unep-wcmc.org/sites/wh/pdf/Shark\%20Bay. pdf, accessed 24 June 2010.

Virilio, P., Pure War, New York: Semiotext(e), 1997.

Virilio, P., Politics of the Very Worst, New York: Semiotext(e), 1999.

Williams, J., Gilles Deleuze's Difference and Repetition, Edinburgh: Edinburgh University Press, 2003.

Young, A., Judging the Image: Art, Value, Law, London: Routledge, 2005. 


\section{Index}

Ada Tree 224-25, 227-28, 230-32, 233 n5, 235 n61-62

Administrative authorisation procedures 48-49, 56

Aesop 156, 166 n7

Agency 10, 15 n14, 29, 42-45, 59 n34, 135-36, 145, 200; European Environment 59 n36, 178, 181, 186 n59 and n82-83; human 30, 42; power/knowledge and $42 ; 45$

Alciato 162-63, 167 n39

Animal: economy of salvation and 154; feed 49, 99, 113, health 49, 56, 97, human and 22, 31-32, 49, 97, 99, $153,160,162,165$; literature 156-57, 159, 161, 165-66; messianum 154, non-human 155, symbolism 12, 156, 159,165 ; taxonomy of 158,198

Animality 2, 12, 153-54, 163: nature and 154

Anthropocentricity/-centrism/-centric: and ecocentricity/-centrism/-centric 4-5, 7, 18, 23, 31

Anthropological machine 153-55

Aristotle 156, 158, 162, 164, 166 n10

Asbestos 74, 76

Autopoiesis 7, 19, 25

Bestiaries 11-12, 155-58, 161-64, 167 n32

Biopolitics/Biopolitical 6, 31

Biotechnology 10, 51, 54, 56, 60 n88, 61 n97, 105ff, 111, 113, 115, 207; agricultural 111

Boundary 26, 29, 31-32, 87-88, 109, 172, 184, 193, 210 n66, 219-20, 224-25, 228; between beings 215; between environmental law and science 4; between human and animal
31 ; between human and natural 6,14 , 18; between park and nonpark 229; between procedural and substantial matters 10; contingency and fluid 2; of environmental law 195; epistemological 3; geographical 67; "inner and outer" 219; jurisdictional 6,67 ; legal 4, 6, 195; of legal science 6; physical 12; of system 28-29

Causality/causation 9, 18, 22, 25, 57, 70-72, 74, 78, 88, 107-8, 179-80

Christianity 156, 158-60

Chronologies, geological and industrial 215, 224, 226

Ciphers 11, 154-55, 158-60, 166, 167 n23; Deciphering 12, 154, 159, 161-62

Clinical risk; see risk $73 f f$

Code, Lorraine 127, 134ff

Common Sense 8-9, 72, 85

Complexity 2, 4, 18, 22, 27, 33-34, $89,94-95,106,129,132,141$, 143, 145, 218

Critical environmental law 1-4, 7-8, 12-13, 18ff, 39-41, 46, 48-49, 56-58, 194-95, 197, 208

Critical legal studies 8, 39-40

Critique 2-3, 7-8, 11, 13, 18, 33, 41-42, 46, 48, 98, 137, 195, 197, 207, 210 n67; external 39; internal 40; legal 40, 57 ; object of 33

De Fournival, Richard 161, 167 n30

Deleuze, Giles 2, 10, 14-15, 117, 122 n36, 214-16, 218, 222, 226, 228-31; and Guattari 2, 6, $15 \mathrm{n} 6,26,35 \mathrm{n} 24$, 216, 228, 233 n9-10, 235 n64-65 and $\mathrm{n} 67$ and $\mathrm{n} 75$ 
Derrida, Jacques 26, 35 n23, 166, 167 n48, 219, 227, 232-33, 235

Didactic: Christian 154, 157, 163; literature 154-55, 157, 159, 166

Directive 2001/18/EC 49-51, 53-54, 56, $60 \mathrm{n} 82-85$

Discourse analysis 8, 39ff

Ecocentricity/-centrism/-centric: and anthropocentricity/-centrism/-centric 4-5, 7, 18, 23, 31

Ecofeminism 11, 31, 126-27, 133ff, 143-44, 148 n47; and sustainability $133 f f$

Ecological thinking 11, 31-33, 127, 134-37, 139-44

Ecology 24ff, 106, 121, 135, 141, 162; of coexistence 115, 118-19; of cultivation 121; Deleuze and $15 \mathrm{n} 4$; and feminism 126, 134; law and 1ff, 105; Open 2-3, 7-8; political 134, 193, 195; Regulatory 10, 68, 112, 116, 118; scientific 66

Economy 9, 21, 23-25, 28, 33, 66, 163, 165, 175; global 155; green 172, 181; political 45; of salvation 154 ; symbolic 219

Emotion: discourses 8, 49-53, 56

Encounter (Deleuzian) 2, 14, $215 f f$

Ethics 5, 15 n14, 21, 33, 54, 65-66, 135-36, 194, 201-2

Ethno-botanical Institutions 13, 195, 200ff

European Commission 61 n98, 89-90, 92, $102 \mathrm{n} 26-27$ and n43, 113, 117, 120

European Food Safety Authority 50, 60 n83 and n88, 111

European Union (EU) 8, 10, 12, 19, $48-58,84,105,111,120,121 \mathrm{n} 1,122$, 138, 171-85

Evans, Edward Paysan 164, 167 n20 and $\mathrm{n} 46$

Foucault, Michel 13-14, 35 n37, 42, 44-49, 55-60, 67, $78 \mathrm{n} 13,136,148$ n67, 193, 195ff, 214, 231

Fragmentation 31: disciplinary 5; of environmental law 19, 200; epistemic 5; land 119

Functional Differentiation 83-84, 101

Future generations 19, 24, 129; see also Intergenerational Equity
Gauchet, Marcel 160, 167 n22 and $\mathrm{n} 28$

Gender 130ff, 144; ecology and 11; equality 20,132 ; mainstreaming 131-32; and nature 134; politics 126; studies 4; sustainability 132

Genetically Modified Crops 105

Genetically Modified Organisms (GMO) 10, 24, 49ff, $60 \mathrm{n} 82$, 90, 111-16, $121 \mathrm{n} 1,123 \mathrm{n} 47$ and $\mathrm{n} 59$

Geography 4, 21, 23-24, 41, 156, 174, 196, 198; Foucauldian 195-96; of knowledge 197; legal 41

Goodrich, Peter 162, 166 n3, 167 n37

Governmentality 45, 59 n60, 68

Guattari, Felix 2, 14 n4, 15 n7; and Deleuze 2, 6, 15 n6, 26, 35 n24, 216, 228, 233 n9-10, 235 n64-65 and n67 and $\mathrm{n} 75$

Hadot, Pierre 167 n18-19 and n24

Haraway, Donna 31, 35 n40

Harm 88, 174, 223; environmental 65, $67,77,174,179-80,182$; human-centred 174; hypothetical 9, 100; legal 174; measurements of 18-19; toxic 67, 69-70, 76-77

Hazard (environmental) 9, 65-71, 73, 75-78, 98, 178, 217, 222, 230; see also Risk

Heraclites 159, 167 n19

Heterotopias/Heterotopic 2, 13, $193 \mathrm{ff}$, 214, 231-32

Heterotopology 13, 195-97, 200-202, 207

Ignorance 9-10, 84, 87-88; decisions under 87-89, 91, 95-98, 100; of environmental law 199; and knowledge 88 ; and risk 10, 88

Inclusiveness 11, 18, 126-27, 130-31, 133-39, 144-45, 147

Intergenerational Equity 20, 128; see also Future Generations

Jaspers, Karl 159-60, 167 n21 and n23 Judicial review 58 n26, 83-84, 93, 95-97, 99-101

Jurisdiction 54, 83-84, 92, 96, 153 , 193, 199 
Justice; corrective 176; Environmental 2, 12-13, 41, 171ff, 198-99; intra-generational 128; legal 179; social 40, 204-5; spatial 12, 173, 176,181

Justiciability 97

Kantorowicz, Ernst 154, 166 n4-5

Lactantius 164, 167 n41

Latour, Bruno 31, 35 n41-42, 122 n10, $124 \mathrm{n} 71$

Legal subject 73

Luhmann, Niklas 7, 10, 19, 28-30, $32-35,102$ n32-34 and n36, 106-7, $122 \mathrm{n} 4-5$

$\log \operatorname{2os}$ 2, 3, 7, 12, 156, 159-61

Monstrosity 214ff; and majesty 214ff,

Monstrous 14, 22, 32, 215-16, 221, 224, 226-28, 230

Morality/Moral 8-9, 29, 66-70, 72, 73, $75-76,127,135,144-45,156-57$, 163,165

Multiplicity: of directions and disorientation 25; of excluded groups 130; existence of 198; heterogeneous 194, 206; of the human 29; of interpretations 10; paradoxical 121; of 'people, plants and justice' 206; of perspectives 7; principle of 200

Natura 159-60, 171

Natural Reserve(s) 13, 195, 200-202, 204, 207

Nature 2-3, 11-14, 27, 29, 31, 39, 66, $76,95,113,126,134,140,154 f f, 181$, 195, 202-3, 205, 214-15, 217-19, 221-22, 228-32, 233 n18; absence of 3 ; and animality 154 ; and Christianity 160; dead 5; of environmental law 2, 11-12, 39; (hu) man and 2, 11-12, 15 n14, 23, 31, 159-61, 202; laws of 146; observation of 158; as oikos 3; organic 113; space of 202; and sovereignty 11,155

Negligence 40, 58 n14, 66, 68-70, 79 n33

Non-Governmental Organisations (NGOs) 11, 42, 128-29, 176, 178, 180,183

Normativity 1, 154, 206
Oikos 2-3, 7, 162

Ovid 156, 166 n7

Paradox 30-33, 88, 106-8, 121, 163, 193-95, 198

Park 14, 201-3, 207, 214-15, 217-22, 224-25, 228-30, 232

Participation 11, 25, 43, 50, 52-53, 93, 126-32, 134, 139, 143-45, 147, 148 n26, 179, 182-83, 203, 206-7, 209 n40

Patriarchy 11, 133

Physis 160; Physiologus 155-59, 161-62, 164-65, 166 n13, 167 n47

Plane of Immanence $14 \mathrm{n} 4$

Pliny 156-58, $166 \mathrm{n} 8$

Pollution 1, 19, 21, 31, 40, 43, 48, 58 n14, 127, 174, 177, 180-83, 202, 217, 219-20

Postecological/post-ecological 7-8, 28

Practical reason 83, 87, 89, 91, 95

Precautionary Principle 9-10, 39, 83ff, 109-10

Protected Area(s) 14, 201-7

Psychomachia 167 n38

Quotidian: epistemology 11, 139-40; experience 142, 144, 146; knowledge $140-42,144-45$

Reflexivity 106, 109, 141

Regulation 9, 19-21, 97, 105-7, 113-14, 116, 119-20, 138-39, 154, 178, 183-84, 217, 222, 225; of biotechnology 10; coexistence 119; environmental 8, 10, 40-45, 47, 49, $58 \mathrm{n} 21,105 f f, 171,179$; ex ante 119; legal 50-51; risk 52; spatial 119

Regulation 1829/2003/EC 49-51, 54-56, $60 \mathrm{n} 83-85$

Resistance 11, 29, 33, 48, 97, 99-100, 144, 183, 200

Risk: anxiety 65; assessment 49-50, 53, $5560 \mathrm{n} 83,69,73,77,87,89,96$, 98-100; calculations 9, 65, 68; clinical risk $73 f f$; and ignorance 10,88 ; insurantial 9, 66, 69, 77; scientific 68-69, 99

Roman law 166, 167 n27

Saeculum 166

Salvation 11-12, 153ff 
Science 2, 4, 8-9, 21, 23-24, 28, 33, 43-45, 47, 49-53, 56, 59 n40, 65ff, $83 f f, 113,118,129,135-40,161,167$ n32, 193, 214, 218, 229-30, 233 n18

Scientific: arguments 52; assessments $85,99,109$; calculations of risk 73 , 77-78; community $128,137-38,149$ n87; data 21, 52-53, 90, 98-99, 109; discourses 44-45, 49-50, 52-55, 73, 205; evidence 70-72, 74, 76, 78, 89, 98-99; knowledge 43-45, 55, 66-67, 137-38, 140, 146; risk assessment 69, 99 ; risk methodology 68 ; uncertainty $21,96,98$

Scripture 159-60

Socio-legal studies 8, 40, 48, 194

Soft law 19, 21, 34 n7

Solidarity 12-13, 171-74, 176-77, 181-84; and territorial cohesion $12-13,171-74,181$

Sovereignty 11, 153-55, 159, 161, 164-65

Space 13-14, 18, 22, 25-26, 30, 41, 47-48, 57, 65, 67, 77, 117-18, 134, $175,183-84,193 f f, 214,216-18,221$, 224, 228; of absence 32; between law and ecology $1 \mathrm{ff}$; of Critical

Environmental Law 19, 194; of critique 7,18 ; epoch of 13 ; and territory 12,184 ; and time 41,225 ; of uncertainty 9

Spatial justice 12, 173, 176, 181

Spatialisation 200-202, 205

Spatiality 10, 175, 180-81, 193-95, 197-99

Subjectivity 2, 8, 32, 90, 135-36, 154, 159, 165, 199, 207
Sustainability $8,13,126 f f, 182$, 218, 228

Sustainable Community 13

Sustainable Development 21, 40, 78 n15, 84-86, 126-29, 132, 143, 146, 172, 182, 203-5, 209 n40

Symbols 155ff; see also animal symbolism

Temporality 6, 19, 24; see also time

Territorial cohesion 12, 171-77, 180-84; and environmental justice 174ff; and solidarity 12-13, 171-74, 181

Territory 12, 171ff, 193, 198, 204; see also space; territorial cohesion

Teubner, Gunther 32, 34-35, 58 n12, 102 n37

Time 20, 22, 25, 41, 47, 50, 164, 202, 204, 206, 208, 215, 218, 225, 231-32; see also temporality

Tobacco toxic tort 76

Topsel, Edward 162, 164, 167 n32-33

Transcontainer 10, 105ff

Transgenic agricultural products 8 , $48-56$

Uncertainty 7-9, 13, 15 n14, 21-22, 24-25, 27, 30, 32-33, 66-67, 96, 98, 100,176

Utopia 13, 30, 41, 195-96, 199, 201-2, 204-5, 208

Virilio, Paul 14, 223-24

World heritage 14, 201, 217, 219-25, 229, $233 \mathrm{n} 26$ and n31 



